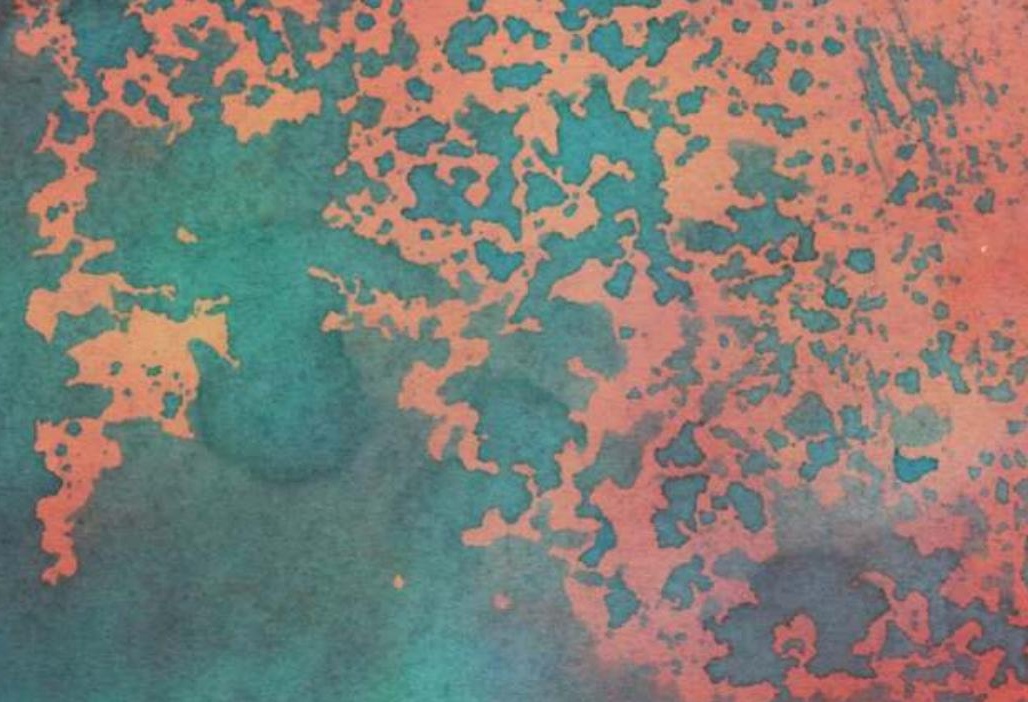

Routledge Studies in Second World War History

\title{
SWEDEN, JAPAN, AND THE LONG SECOND WORLD WAR 1931-1945
}

Authored by Pascal Lottaz and Ingemar Ottosson with an Essay by Bert Edström
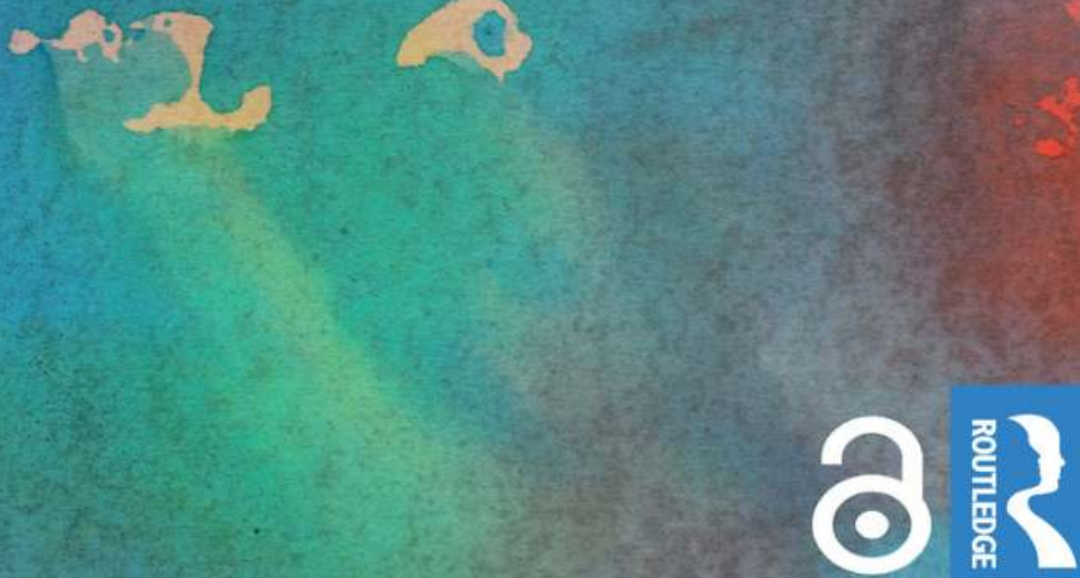


\section{Sweden, Japan, and the Long Second World War}

Authored by Pascal Lottaz and Ingemar Ottosson with an Essay by Bert Edström

Lottaz and Ottosson explore the intricate relationship between neutral Sweden and Imperial Japan during the latter's 15 years of warfare in Asia and in the Pacific. While Sweden's relationship with European Axis powers took place under the premise of existential security concerns, the case of Japan was altogether different. Japan never was a threat to Sweden, militarily or economically. Nevertheless, Stockholm maintained a close relationship with Tokyo until Japan's surrender in 1945. This book explores the reasons for that and therefore provides a study on the rationale and the value of neutrality in the Long Second World War.

Sweden, Japan, and the Long Second World War is a valuable resource for scholars of the Second World War and of the history of neutrality.

Pascal Lottaz is Assistant Professor of International Relations at Waseda University, Japan.

Ingemar Ottosson is Associate Professor of History at Lund University, Sweden. 


\section{Routledge Studies in Second World War History}

The Second World War remains today the most seismic political event of the past hundred years, an unimaginable upheaval that impacted upon every country on earth and is fully ingrained in the consciousness of the world's citizens. Traditional narratives of the conflict are entrenched to such a degree that new research takes on an ever-important role in helping us make sense of World War II. Aiming to bring to light the results of new archival research and exploring notions of memory, propaganda, genocide, empire, and culture, Routledge Studies in Second World War History sheds new light on the events and legacy of global war.

Recent titles in this series

\section{A New Nationalist Europe Under Hitler}

Concepts of Europe and Transnational Networks in the National Socialist Sphere of Influence, 1933-1945

Edited by Johannes Dafinger and Dieter Pohl

\section{The Swedish Jews and the Holocaust}

Pontus Rudberg

\section{Mussolini's Army against Greece}

October 1940-April 1941

Richard Carrier

Sweden, Japan, and the Long Second World War 1931-1945

Pascal Lottaz and Ingemar Ottosson with an Essay by Bert Edström

\section{War Through Italian Eyes}

Fighting for Mussolini, 1940-1943

Alexander Henry

For more information about this series, please visit: https://www.routledge.com /Routledge-Studies-in-Second-World-War-History/book-series/WWII 


\section{Sweden, Japan, and the Long Second World War \\ 1931-1945}

Authored by Pascal Lottaz and Ingemar Ottosson with an Essay by Bert Edström 
First published 2022

by Routledge

2 Park Square, Milton Park, Abingdon, Oxon OXI4 4RN

and by Routledge

605 Third Avenue, New York, NY 10158

Routledge is an imprint of the Taylor \& Francis Group, an informa business

(C) 2022 Pascal Lottaz and Ingemar Ottosson

The right of Pascal Lottaz and Ingemar Ottosson to be identified as the authors of this work has been asserted in accordance with sections 77 and 78 of the Copyright, Designs and Patents Act 1988.

The Open Access version of this book, available at www.taylorfrancis. com, has been made available under a Creative Commons AttributionNon Commercial-No Derivatives 4.0 license.

Trademark notice: Product or corporate names may be trademarks or registered trademarks, and are used only for identification and explanation without intent to infringe.

British Library Cataloguing-in-Publication Data

A catalogue record for this book is available from the British Library

Library of Congress Cataloging-in-Publication Data

A catalog record has been requested for this book

ISBN: 978-1-032-02142-3 (hbk)

ISBN: 978-1-032-02141-6 (pbk)

ISBN: 978-1-003-18206-1 (ebk)

DOI: $10.4324 / 9781003182061$

Typeset in Galliard

by Deanta Global Publishing Services, Chennai, India 
To Margret Kühnis-Butz, beloved grandmother, and Stig Ottosson Miller, treasured uncle.

We miss you. 


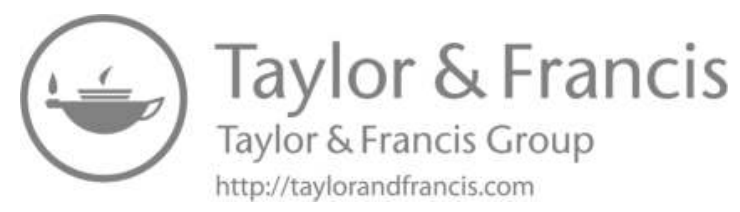




\section{Contents}

Lists of figures, pictures, and tables ix

Preface xi

Acknowledgments xiii

Additional Acknowledgments and Disclaimer Concerning

the Open Access Publication of this Work xiv

List of abbreviations $\quad \mathrm{xv}$

1 Introduction 1

A Scandinavian neutral and a belligerent faraway 2

Neutrality and the problem of being friends with enemies 4

The long Second World War 1931-1945 7

Wartime diplomacy 9

Notes 11

2 In the beginning: Early Swedish-Japanese relations

The impact of 190516

From the Great War to the interwar period 19

Institutions and decision makers 24

Notes 25

3 Trade under protest: A war in all but name

International politics 29

National politics 32

Diplomacy 37

Trade 46

Summary 54

Notes 55

4 Fading protest: Total war in China

International politics 61

National politics 62 
viii Contents

Diplomacy 71

Trade 77

Summary 84

Notes 85

5 Staying relevant: Total war in Europe

International politics 92

National politics 96

Diplomacy 105

Trade 114

Summary 117

Notes 118

6 Fully engaged: Total war in the Pacific

International politics 125

National politics 126

Diplomacy 129

Trade 146

Summary 153

Notes 154

7 In the end: Widar Bagge, Japan, and the end of World War II

The Bagge peace feeler 160

Diplomats in action in Stockholm 169

Concluding remarks 174

References 177

8 Conclusion

After war 181

Final remarks 183

Notes 186

Bibliography

Appendix

Index 


\section{Figures, pictures, and tables}

\section{Map}

$1 \quad$ Japan's territorial expansion 1931-1942

$\mathrm{xvi}$

\section{Pictures}

3.1 Matsuoka Yōsuke throws around a representative of the small states

5.1 Widar Bagge in 1936

5.2 Widar Bagge in 1945

6.1 The Gripsholm anchoring in Barcelona

6.2 Evacuation notice by the Swedish legation in the Japan Times

\section{Figures}

1.1 Swedish imports and exports for selected countries in $1938 \quad 4$

2.1 Swedish imports and exports to Japan 1908-1914 19

2.2 Swedish imports and exports to Japan 1914-1930 20

3.1 Japanese imports and exports for selected countries in $1931 \quad 47$

3.2 Swedish imports \& exports to Japan 1931-1937 50

3.3 Growth of soybean imports from Manchukuo to Sweden 1932-1936

4.1 Swedish imports and exports to Japan 1937-1941 80

5.1 Number of times Japan is mentioned in major Swedish newspapers 1930-1946

5.2 Swedish imports and exports to Japan 1939-1941 115

6.1 Number of Swedish Protecting Power mandates for country 1939-1945

6.2 Swedish imports and exports to Japan 1942-1945 147

8.1 Value of imports from and exports to Japan 1947-1952 182 


\section{Tables}

2.1 Swedish representatives to Japan 1871-1945 15

2.2 Swedish trade with selected countries in 1928 and 1938

2.3 Structure of the Swedish exports to Japan in $1928 \quad 21$

2.4 Swedish trade with Japan 1928-1932 22

2.5 Japanese trade with Sweden 1928-1932 22

5.1 Personnel of the Swedish mission to Japan in $1937 \quad 110$

5.2 Japanese diplomats in Sweden in $1942 \quad 112$

6.1 Countries/Territories in which Sweden represented Japanese interests 131

6.2 Countries whose interests Sweden represented in Japan 132

6.3 Composition of the Neutral Committee of the YMCA 142

6.4 Japanese diplomats in Sweden in 1945

A.1 List of Swedish Cabinets between 1931 and $1945 \quad 205$

A.2 List of Japanese Cabinets between 1931 and $1945 \quad 206$

A.3 List of Swedish representation of foreign interests in World War II 


\section{Preface}

This is a work in historical international relations. It tells the story of the bilateral relations between Sweden and Japan during 15 crucial years of world history. As such, this book seeks to combine an understanding of large movements in international relations with details of archival sources. The period 1931-1945 is a long one for a short book. We naturally had to make difficult decisions as to what narratives to include, which focuses to set, and whose observations to incorporate-at the expense of other stories. The danger of this venture is that we might be too detailed for the international relations scholars who want to know how these nations behaved, but too shallow for the historians who are interested in details about people and institutions. We have been trying to strike a balance and speak to both audiences by following three main themes, which we tie together around a central framework. We focus on politics, trade, and diplomacy in a narrative about neutrality because that was the enabling factor of SwedishJapanese relations, especially after 1937. It is an unconventional framework but one that befits the Swedish experience of the wartime period. Each chapter offers an account of the three subjects. In addition, Bert Edström added an insightful essay about an episode in Swedish-Japanese relations that is so important that it warrants its own chapter. For the busy reader, we have devised a relatively sleek introduction, chapter summaries, and a conclusion, which we hope will make the book more accessible.

A bilateral relationship is a two-way street with politicians, diplomats, businesspeople, and private individuals of one country engaging with their counterparts in the other. Although this book tries to balance the discussion, it is narrated from the viewpoint of Sweden. It delves into Japanese perceptions only occasionally, which is one of the limitations of this study. An account from the Japanese side has yet to be written. Furthermore, this is the first book-length study in English to deal with the experiences of a European neutral in the Asian theater of the Second World War. There are several more diplomatic experiences of neutrals and their engagements in Asia awaiting scrutiny. Some have received scholarly attention in their national languages, but much work remains to be done. By providing the Swedish story in English, we hope to make this national experience accessible and therefore contribute to the global history of the Second World War. 
xii Preface

\section{Notes on names, places, and translations}

Whenever possible, we use the historical place names. Especially for cities and some geographical areas, we use the names which appear most often in source documents to refer to them. Modern-day names are added in brackets. This is especially important for Chinese city names which, today, are romanized differently from 80 years ago. Occasionally, we use Japanese-language versions of names for territories that today are again Chinese. We do so when the Japanese version was the internationally most popular way to refer to that territory (for example, Dairen instead of Dalian). We adopted this naming convention purely for the sake of historical clarity. For Japanese names, we use the Hepburn system of romanization, and we adhere to the East Asian style of writing family names before first names. English translations of quotations from Swedish, Japanese, and French are our own, unless explicitly stated. 


\section{Acknowledgments}

This book is the outcome of a long research process, during which we both got indebted to many people. First and foremost, we would like to thank our families: Susanne, Raphael, and Alexander Lottaz, as well as Makiko, Mariana, and Michaela Ottosson. Their unwavering positivity and loving support have enabled us to concentrate and work productively on this research.

We also owe much gratitude to all the colleagues who have helped us with comments, discussions, or advice. First among them is Bert Edström, who has not only reviewed the manuscript but even agreed to supply an entire chapter based on a very valuable essay he wrote in 1995. His research about the "Bagge Maneuver" is a highly detailed account of one of Japan's peace feelers that involved Sweden. The text became a working paper of the Center for Pacific Asia Studies at Stockholm University but went out of print. We are happy to reintroduce it here in an updated form as the culminating chapter of this book. We thank Bert very much because his work makes this account of Swedish-Japanese relations so much richer.

Other scholars have mentored and encouraged us along the way. Their perspectives were invaluable to this work. Particularly, we thank Kitaoka Shin'ichi, Neville Wylie, and Herbert R. Reginbogin. We also thank the many people who have supported us with their work. Especially, Angelina and Boban Pavic, who have provided us with valuable books. Örjan Romefors of the Swedish National Archives has given us much needed advice on some of the sources, and Ronny Andersson helped us in finding pictures of Envoy Widar Bagge. In addition, we also thank the historians Akiyama Kaori, Gerhard Krebs, and Ishihara Shunji for answering questions and pointing us to sources.

We also had research assistants who helped us much. Alexander William Klinger helped us with parts of the manuscript and special thanks go to Nhữ Đình Nguyên (Wen) for his valuable assistance in compiling and cleaning the chapters, notes, and the bibliography. We also thank our home institutions, the Waseda Institute for Advanced Study and Lund University, for the freedom and support they gave us to pursue this research.

Last but not least, we want to thank each other. Co-authoring a book based on years of research harbors the potential for friction but the level of cordial understanding between us bears fruit in this account. It was a very enjoyable intellectual journey.

Tokyo and Lund, September 2020 Pascal Lottaz and Ingemar Ottosson 


\section{Additional Acknowledgments and Disclaimer Concerning the Open Access Publication of this Work}

Half a year after its initial publication, this book was converted into an Open Access title, thanks to the financial support of Ekman of Co $A B$ and Gadelius Holding Ltd. We approached the companies after completing and submitting the manuscript because they appear several times throughout our narrative. They are, in fact, an important part of Swedish-Japanese relations, and living proof of the continuity of history. Neither company had an influence on the research process.

We thank Ekman \& Co AB and Gadelius Holding Ltd for their kind and generous support, making this research online available for free.

Pascal Lottaz and Ingemar Ottosson November 2021, Tokyo and Lund.

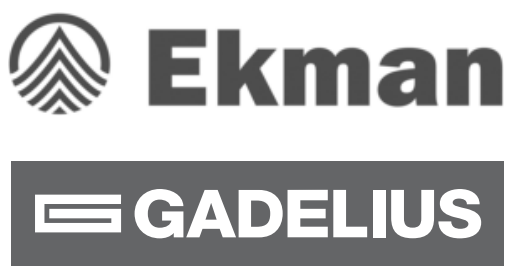

Established in Japan, 1907 


\section{Abbreviations}

$\begin{array}{ll}\text { AFL } & \text { American Federation of Labor } \\ \text { BA } & \text { Beskickningsarkiv (Swedish Missions Archives) } \\ \text { DDS } & \text { Diplomatic Documents of Switzerland } \\ \text { ICRC } & \text { International Committee of the Red Cross } \\ \text { ICRCA } & \text { International Committee of the Red Cross Archives } \\ \text { LO } & \text { Landsorganisationen (Federation of Trade Unions) } \\ \text { MP } & \text { Member of Parliament } \\ \text { NYK } & \text { Nihon Yüsen K.K. (Nihon Yūsen Ltd.) } \\ \text { POW } & \text { Prisoner of War } \\ \text { RP } & \text { Riksdagens Protokoll (Parliamentary Records of the Swedish } \\ & \text { Riksdag) } \\ \text { SEK } & \text { Swedish Crowns (kronor) } \\ \text { SKF } & \text { Svenska Kullagerfabriken (Swedish Ball-Bearing Factory) } \\ \text { SJS } & \text { Svensk-Japanska Sällskapet (Swedish-Japanese Association) } \\ \text { SSU } & \text { Swedish Social Democratic Youth Union } \\ \text { UD } & \text { Utrikesdepartementet (Swedish Ministry for Foreign Affairs) } \\ \text { UDA } & \text { Utrikesdepartementets Arkiv (Archive of the Swedish Ministry } \\ & \text { for Foreign Affairs) } \\ \text { UN } & \text { Utrikesnämnden (Advisory Council on Foreign Affairs) } \\ \text { US } & \text { United States } \\ \text { UU } & \text { Utrikesutskottet (Parliamentary Foreign Policy Committee) } \\ \text { USSR } & \text { Union of Soviet Socialist Republics } \\ \text { WWI } & \text { First World War } \\ \text { WWII } & \text { Second World War } \\ \text { YMCA } & \text { Young Men's Christian Association } \\ \text { YSB } & \text { Yokohama Specie Bank }\end{array}$


The Japanese Empire, 1931-1945

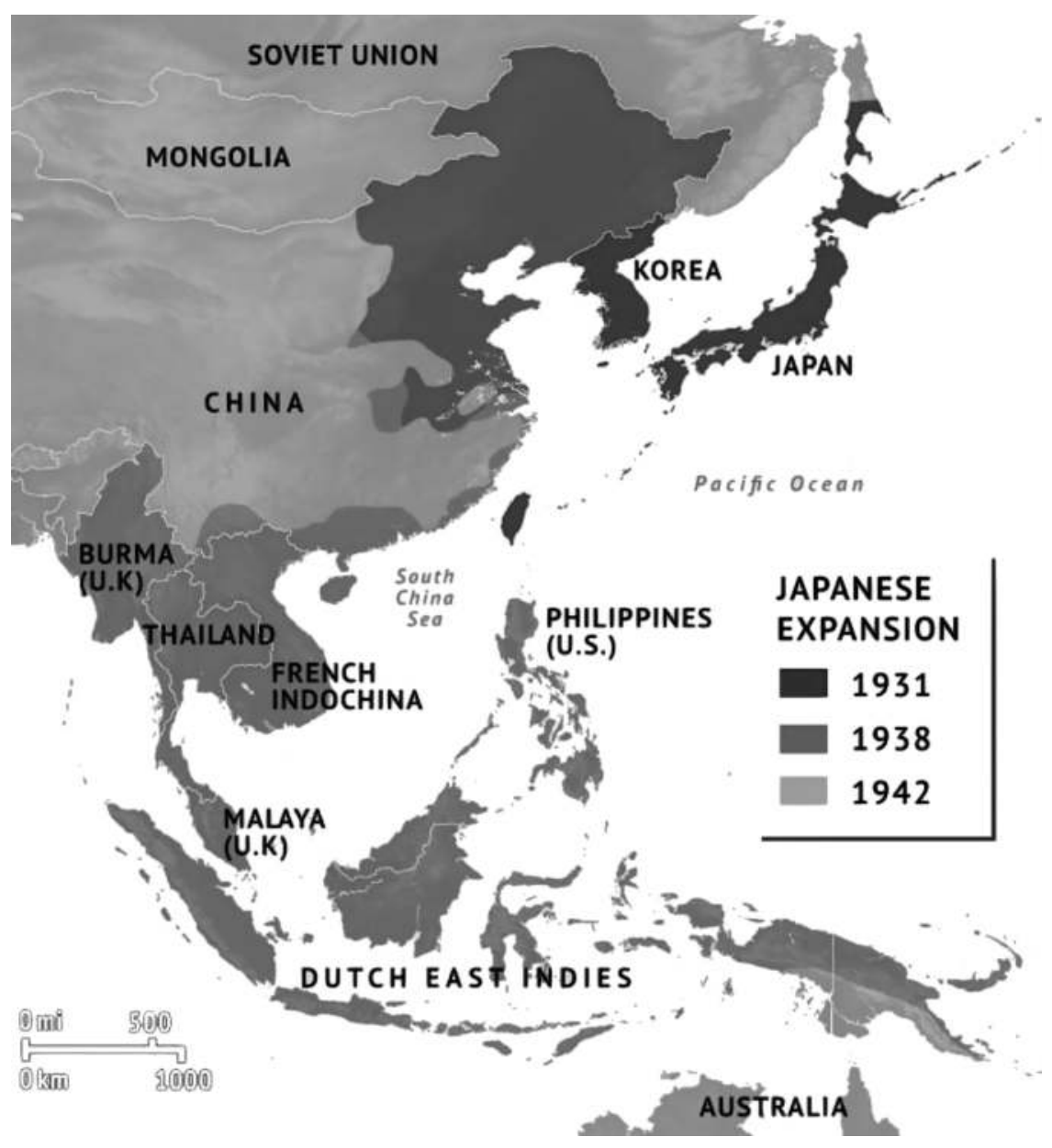

Map 1 Japan's territorial expansion 1931-1942 (https://worldview.stratfor.com/ article/japans-territorial-expansion-1931-1942). Republished with the permission of Stratfor, a leading global geopolitical intelligence and advisory firm. 


\section{Introduction}

On the night of April 13, 1945, a lonely plane crossed the Japanese Sea. Coming from Tokyo, at the height of Japan's doomed war in the Pacific, the aircraft was not carrying bombs or soldiers, but a foreign diplomat- the Swedish envoy to Japan, Widar Bagge. ${ }^{1}$ It was a solemn flight in several ways for Stockholm's most senior representative in East Asia. For one, it was an emotional farewell after more than a decade of service in Tokyo, where he witnessed some of Japan's brightest moments as well as its darkest days. ${ }^{2}$ He knew the "good" Japan of the 1920s, the cooperative contributor to the League of Nations, the supportive pillar of internationalism, and the friendly nation that welcomed foreigners to trade and collaborate. But he also experienced first-hand the Japan of violence, xenophobia, and murder, when fanatics militarized society, assassinated politicians, and invaded numerous territories in the name of the Empire's "natural" right to lead the peoples of Asia. ${ }^{3}$ Finally, when the bombs started falling, he had to watch the slow but steady destruction of a country he loved.

Bagge's departure was also literally a solitary flight as no other diplomat or foreign civilian could have even dreamed of leaving Japan on a plane this late into the war. He was air-lifted to Manchuli (Manzhouli), a northern Manchurian town under Japanese control that bordered the Soviet Union. From there, he could take the trans-Siberian that connected him via Moscow to Stockholm. The flight was a special privilege that he only received because of excellent contacts to the Empire's most senior politicians and an extraordinary plan: to bring about a negotiated peace between Japan and the United States. The so-called "Bagge maneuver" or "Bagge peace feeler"-subject of Chapter 6-was ultimately unsuccessful but the episode incarnates a central message of this book. Sweden, a country that was neither an ally nor an enemy of the Empire, had a part to play in the events that would shape Asia and the Pacific for generations to come. During World War II, Sweden was a neutral country, but that did not incapacitate its diplomacy. On the contrary, because of its neutral position, Sweden remained constantly involved in global diplomacy. Not only could Bagge fly out of Japan at a precarious moment but he was proactively approached by peace-inclined Japanese to help them in the grimmest of times in a way that merely a handful of countries were still able to do. Only Switzerland and Spain were in a comparable position. ${ }^{4}$ This book tells the Swedish story. ${ }^{5}$

DOI: $10.4324 / 9781003182061-1$ 


\section{Introduction}

\section{A Scandinavian neutral and a belligerent faraway}

Sweden's experience of World War II was significantly different from that of many other nations. While large parts of the world were consumed by the inferno of total war, Sweden did not share that violent fate because it never joined the fighting. It proclaimed its neutrality toward the various theaters of war, vowing not to take sides, in accordance with the provisions of international law. There exists a widespread misunderstanding that neutrality during wartime requires a neutral state to disengage from contact with belligerent nations, and that economic or political interactions are a breach of "strict" neutrality. That is simply wrong. The opposite is the case, as the Law of Neutrality (a part of international law) explicitly guarantees the right of neutral countries to trade and interact with belligerent states. That is precisely what Sweden did during World War II. It continued normal diplomatic and economic relations with Allied and Axis Powers alike-including Japan.

There is, nevertheless, something odd about Swedish wartime diplomacy toward Japan. Despite strong ideological differences and heavy Swedish criticism on Japan's bellicose behavior (first in China and then in Southeast Asia and the Pacific), diplomatic interactions between the two nations did not weaken but intensified over time. For example, the Swedish legation in Tokyo grew from 3 people in the late 1930s to over 20 in 1945. Telegrams from Bagge to the Foreign Ministry, the Utrikesdepartementet (UD), increased from one or two per week to several messages daily, and while Stockholm used to host only a few Japanese diplomats - five in 1931 and merely one in 1941 - by the time Tokyo surrendered to the Allies 55 people were working for the Japanese mission. The longer the war lasted, the more Japan began to invest in its diplomatic ties with the only remaining Nordic neutral. What makes this situation more noteworthy is that, at the same time, trade between the two countries collapsed. During the strongest year of bilateral trade, in 1937, Sweden imported goods for over 12 million crowns from Japan but in 1945, less than 0.3 million crowns worth of goods still reached its shores.

How can we explain this bond between the bellicose, militaristic Japan and neutral, democratic Sweden, especially when trade - one of Sweden's main interests in Japan-diminished so drastically? Did a solid friendship connect the two countries or did the necessities of the days dictate the movement of their relationship? Was there something more? Maybe something sinister, an inglorious part of Sweden's national history? In the wake of revelations in the 1990s about the collaboration of World War II neutrals with Nazi Germany, Sweden had already had to accept much criticism for its interactions with Axis Powers. ${ }^{6}$ In 1991 Swedish journalist, Maria-Pia Boëthius, published a controversial book titled Heder och samvete [With honor and conscience]. It was an emotional indictment of Swedish foreign policy during the war years, which started a long period of soul-searching. ${ }^{7}$ The debate focused on the question whether Sweden's engagement with Nazi Germany was done to protect the country from an invasion or if Sweden, like other neutrals, willingly became an accomplice of Hitler, purely for business 
interests. Should we expect to find a similar dynamic in Sweden's interactions with the easternmost Axis Power?

The short answer is no. Our book, in fact, argues that the case of SwedishJapanese relations sheds a new light on neutral wartime diplomacy because classic World War II frames of reference do not apply. The question, for instance, whether Sweden collaborated with Japan for reasons of military security or business interests makes little to no sense. There is no reason to analyze Swedish interactions with Japan under the same existential premise as its relations with European powers. From a militarily point of view, Sweden had nothing to fear from Japan. The two countries were separated by a continent and despite Sweden having had "unequal treaties" with Japan and China until late in its semicolonial history, it had no territorial interests overseas in the way the British, the Dutch, or the United States had. ${ }^{8}$ Under no rational scenario could Japan have ever posed a security threat to Stockholm. In Europe, on the other hand, Sweden was caught in a most delicate situation. Germany, Great Britain, and the USSR were all threats to Swedish security. Belligerents routinely ignored the rights of neutrals when it suited their military tactics. Nazi Germany (besides all of its other crimes) occupied neutral Norway, Denmark, the Netherlands, and Belgium. The Soviet Union attacked the neutral Finns and gobbled up the neutral Baltic States. The British invaded neutral Iceland and neutral Iran while their allies in the Pacific invaded the neutral Portuguese colony of (East) Timor. In other words, the Swedish Government had every reason to fear an invasion from its immediate neighbors, but not from Japan.

Economically, too, Swedish dependence on trade with European belligerents presented a particular weakness in negotiations, while its trade interests with Japan were modest at best. In 1938 less than 1 percent of Swedish imports were sourced from Japan while only 1.4 percent of exports went there. ${ }^{9}$ Although Japan was Sweden's largest trading partner in Asia, it was not a vital market, not in comparison to its bellicose neighbors for which, in the same year, 21 percent of imports came from Germany, 16 from the United States, and 12 from Britain respectively. ${ }^{10}$ (Figure 1.1)

As unexceptional as these trading numbers are, it is noteworthy that diplomacy and trade with the Empire continued throughout the wartime period. ${ }^{11}$ In fact, it is one of the arguments of this book that Sweden continued to trade with Japan while simultaneously protesting against its unlawful expansionism. Considering how dire Sweden's situation in Europe was, it is, however, somewhat puzzling that Stockholm did not simply recall its diplomats and expatriates after Japan entered the war with the Allies - all the more so if one considers how hostile the Empire had become to European foreigners. ${ }^{12}$ In August 1940, more than a year before the outbreak of the War in the Pacific, a Reuters journalist, M.J. Cox, died during police detention. He fell from the third floor of the building where he was interrogated. Japanese Military Police claimed suicide but the international community in Tokyo drew a different conclusion, suspecting murder. ${ }^{13}$ Another British national, Frederik Ringer, who served as Swedish Consul in Nagasaki also died the same year while in detention, prompting even long-term 


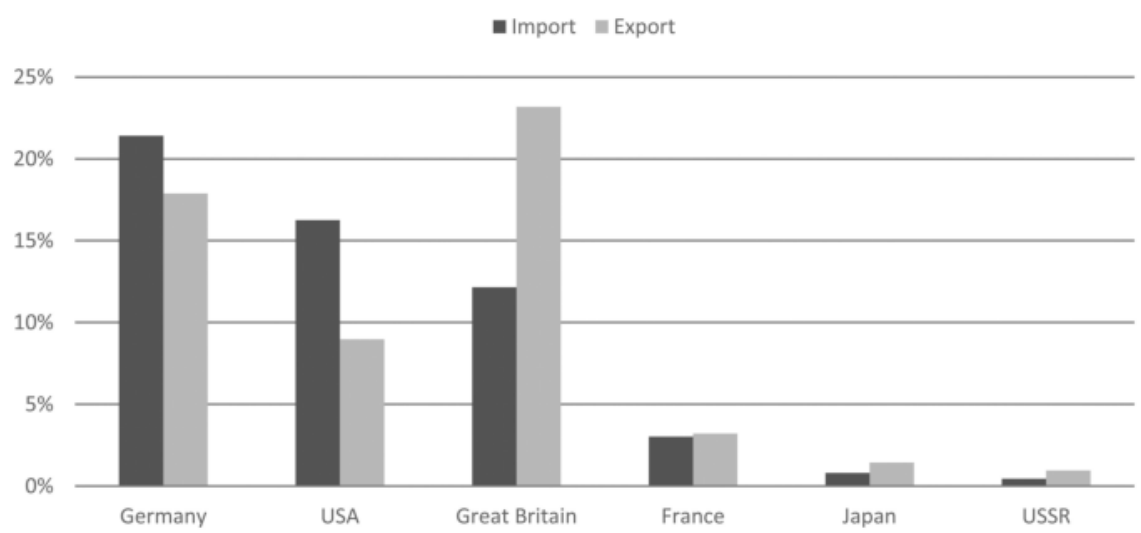

Figure 1.1 Swedish imports and exports for selected countries in 1938. Source: Statistiska Centralbyrån, Statistisk årsbok för Sverige, 1939, 168-169.

European residents in Japan to leave the country. The tenser the international situation got, the worse Japanese military repression against foreign nationals became. Widar Bagge reported at the time that “the possibility of Japan's entry into the war carries special risks for its white inhabitants in view of the strong increase in xenophobia." ${ }^{14}$ So, why then the continuous engagement? It would have been possible for Stockholm to evacuate the roughly one-hundred expatriates-even after Pearl Harbor. But the UD decided not to do so. This book will explain the history of Stockholm's decision to remain engaged with Japan from its first unlawful blunders in Manchuria until the bitter end after Hiroshima and Nagasaki. What were the motives? Who were the actors? And how did economic, political, and diplomatic considerations intertwine? In short, why and how did Sweden engage with Japan during its wartime period?

To find answers, we analyze four dimensions of Swedish-Japanese interactions. First, the international context in which the two countries operated. Second, the national political debates in the Riksdag (Swedish Parliament), Government, and popular media (mainly newspapers, books, and magazines). Third, economic interactions as recorded in trade statistics, reports, and telegrams. And fourth, the diplomacy between the two states based on a study of original documents. Some of the episodes that this book discusses have already been explored by historians but much of it draws on new sources from Swedish and Japanese archives. ${ }^{15}$ Together, these documents tell the story of the relationship between Scandinavia's last wartime-neutral and a belligerent faraway. ${ }^{16}$

\section{Neutrality and the problem of being friends with enemies}

The importance of neutrality for Sweden's foreign policy during World War II can hardly be overemphasized. While most other countries (and their colonies) 
in Europe, North America, and Asia sunk into the chaos of total war, Sweden did not have enemies - at least not formally. On the diplomatic level, Stockholm did not differentiate between Japan, China, the USSR, Germany, or the United States. It maintained friendly relations with all of them. The problem was that Sweden's "friends" were at war with each other, which naturally created pressures from all sides. To be friends with enemies came at the cost of criticism from all of them for not supporting their war efforts-or for granting too many favors to the respective enemy. Whenever Swedish foreign policy was supportive to one side, it could be sure to arouse the anger of the other. The dilemma was best expressed by one of Sweden's most prominent foreign policymakers of the twentieth century, Östen Undén, foreign minister (1924-1926 and 1945-1962), who once privately conceded that this "fact must perhaps be accepted with resignation, but the apostles of neutrality will never be heralded as the liberators of mankind." 17 Neutrals could not expect much understanding from either side of the war for not supporting their cause.

Even worse, there was little prospect that belligerents would recognize the rights of neutral countries out of love for international law, and there were no mechanisms to guarantee the rights. After all, the international order of the League of Nations had been dysfunctional ever since the League's failure to punish Japan for its aggression against China in 1931 and had collapsed completely after Italy's campaign against Abyssinia in 1936. The Law of Neutrality, which was a part of international law (developed over centuries but formalized at the Hague Conventions of 1899 and 1907), was, in this sense, mere guidelines for the dos and don'ts of neutral states, but it was not at all a guarantee against aggression. The UD had no illusions about the gravity of the situation and the relative vulnerability of Sweden. In April 1939, Erik Boheman, the state secretary for foreign affairs (the UD's highest-ranking civil servant), drafted a note that was approved by Foreign Minister Rickard Sandler and circulated among the highest ranks of Sweden's foreign policymakers, including Prime Minister Per Albin Hansson and the ex-foreign minister, Östen Undén. It read like the blueprint for a pragmatic neutrality in case of another general war in Europe. He predicted that there was no reason to believe that belligerents would respect the rights of neutral states any more than they did during the First World War. There was, according to Boheman, nevertheless no direct reason for Sweden to fear an attack as his country was not part of any of the blocks that had been forming. But its wealth in iron ore, on the one hand, and its relative economic vulnerability, on the other, would still pose major problems to Sweden's neutrality. The relatively rare but important metal would be sought after by different belligerents while the trade-dependent economy would make Sweden susceptible to pressure-politics. Boheman's recommendations were clear; Swedish neutrality had to be negotiated bilaterally with all belligerents and in all spheres, including commerce, as not to become a target of reprisals by one or the other side. ${ }^{18}$ Sweden should, in other words, be ready to compromise if national security and national interests demanded it. Practitioners like him understood that the Law of Neutrality could only serve as guidelines for Swedish conduct during a general 


\section{Introduction}

war but that there was no mechanism to compel belligerents to respect neutral rights. This became especially apparent in Northern Europe where, with the only exception of Sweden, not a single neutral escaped invasion by one or the other side of the war.

Boheman's predictions were eerily accurate. Once the European war started, Sweden's two biggest problems were its dominant position as one of the continent's largest exporters of iron ore and its geographical position between the belligerents. Iron ore was a crucial primary material for the production of steel, abundant in Sweden's north, but exceedingly rare in central Europe. That created a sensitive vulnerability for Germany who, by 1939, imported roughly 40 percent of its iron ore from Sweden. Had these shipments ceased, the German armament industry would have seriously suffered. In fact, the raw material was so essential to the German industry that Swedish diplomat Gunnar Hägglöf was convinced that had the iron ore mines been located in the south, Germany would most likely have occupied Sweden for the sake of uninterrupted access. ${ }^{19}$ Their isolated location in the high north and the implicit threat that should an attack happen, Sweden would destroy these facilities before an aggressor could seize them, provided a strong discouragement to any German military intervention, and gave Sweden a bargaining chip in economic negotiations with both sides. Together with Sweden's exports of ball bearings, the iron ore supply was the country's most vital "contribution" to Hitler's war economy. Naturally, Britain, once at war with Germany, demanded that Sweden cease all exports, even threatening to attack Swedish mines should shipments continue. ${ }^{20}$ Four years later, it was the US chief negotiator who threatened bombing factories and distribution centers in Gothenburg should Swedish exports of iron ore and ball bearings to Germany not end. ${ }^{21}$ Germany, on the other side, threatened to stop crucial deliveries of coal, coke, and steel if Sweden did not meet the demanded quotas of iron ore exports. Stockholm solved the problem by negotiating War Trade Agreements with Great Britain and Germany (in late 1939 and early 1940), reaching compromises with both of them. All political provisions were, however, highly volatile, depending heavily on the developments of the war. ${ }^{22}$ After Germany attacked and occupied Denmark and Norway on April 9, 1940, Swedish trade with Allied nations was cut off to a large extent, which led to even closer integration of Swedish commerce with the German "Grossraumwirtschaft" (the Nazi vision for a continental economic zone). Four years later, when the Allies strode toward victory after landing in Normandy on June 6, 1944, the situation inversed, and Stockholm yielded to their pressure to stop exports to Germany altogether. Such developments have earned Sweden's wartime foreign policy the reputation of having been reactive. ${ }^{23}$ However, as the overriding goal of Hansson's multiparty coalition cabinet was to avoid war, there were only two considerations that mattered when it came to concessions: would their refusal lead to an invasion or would their acceptance lead to a counterattack by the other side?

The most controversial Swedish compromises had to do with concessions to Hitler for the transport of German cargo, weapons, and even troops on Swedish Railways. In these episodes, too, Sweden's main problem was its geostrategic 
position. Once Denmark and Norway had fallen prey to Germany, and with Finland allied to it, Hitler's diplomats started demanding that troops could be transported through Swedish territory between Norway and Finland. After months of negotiations, and much to the consternation of the entire cabinet, the Government felt unable to resist the demands any longer without the serious risk of being invaded like its neighbors. In July 1940, at a time when the situation for liberal democracies in Europe was at its bleakest-Paris, Kaunas, Riga, and Tallinn had fallen to Germany and the Soviet Union just days before-Sweden agreed to German troop transports through its territory. Hansson was painfully aware of the seriousness of the concession, which was not only a grave infringement on the letter and the spirit of the Law of Neutrality but would probably lead to more German demands as well. ${ }^{24}$ Indeed, those followed immediately with Sweden granting more rights of transit for German soldiers to travel back home and, in 1941, the right of the "Engelbrecht" division to pass through Sweden on its way to the Eastern front-all obtained from the Swedish Government under the German threat of regarding refusals as "unfriendly acts." 25

In short, Sweden had no enemies during the war but its "friends" were not of the friendly kind. Nevertheless, the outcome of the tight-rope walk was that Swedish sovereignty remained intact. Sweden maintained its democratic government and continued peaceful interactions with all Axis and Allied countries alike during the 1930s and 1940s. Although those decades were dangerous to Sweden's national security, from its perspective, there was no break in relations with the belligerents the way that they severed relations among one another. That, in turn, enabled the Swedish Government and its nationals to interact not only with immediate European neighbors but with the rest of the world, too.

\section{The long Second World War 1931-1945}

Swedish neutrality also provides a special temporal frame to conceptualize Japan's wartime period, based on a narrative of continuity more than rupture. Most importantly, the standard periodization of the Second World War (ranging from 1939 to 1945) is not very useful to understand Sweden's interactions with Asia. When Hitler attacked Poland on September 1, 1939, nothing exceptional happened in Tokyo or in Stockholm. Certainly, diplomats and politicians in both countries were stunned by the news-like much of the world-but they were not drawn into the conflict. In fact, what today is considered Sweden's “wartime cabinet" 26 was not formed until December 13, 1939, while in Japan cabinet infights continued throughout 1939-1941. Both countries struggled to find political positions toward the war in Europe, but between Sweden and Japan, no change in bilateral relations occurred. In fact, Japan reacted to the outbreak of war in Europe just like Sweden, Switzerland, and the United States, by declaring that it would not join the fight. ${ }^{27}$ "Japanese neutrality" (subject of Chapter 5) toward the European conflict would hold for two years until its Navy attacked the US fleet in Pearl Harbor on December 8, 1941. Only then a cascade of declarations of war followed that ended peaceful relations between Japan and the Allied 


\section{Introduction}

Powers. For many Western diplomats and civilians in the Empire and, vice versa, Japanese nationals in the West, that was the beginning of prolonged internment and much suffering. The US ambassador to Japan, Joseph C. Grew, and his staff, for example, were immediately cut off from all contact with the outside world and confined to their embassy premises - a fate shared by all enemy diplomats at the outbreak of the war and reciprocally applied to Japanese diplomats in Allied countries. Since Sweden again stayed neutral, Stockholm's relations with Tokyo remained as intact as those with Washington, Berlin, Rome, and London. If anything, Swedish diplomacy intensified with the outbreak of the Pacific War because Stockholm assumed responsibilities as a Protecting Power. That was due, in part, to the loss of other neutrals who had been filling that role until Pearl Harbor (foremost the United States) and, second, because of the desperate situation that Japan maneuvered itself into. Tokyo lost most diplomatic friends as the war progressed and the "club of neutrals" who were able to help the Empire negotiate with its enemies shrank drastically during the last years of the war, like the Soviet Union and Turkey who declared war in summer 1945, or Spain, which ruptured diplomatic ties in April after the Manila Massacre. Sweden and Switzerland were the only two neutrals who remained friendly with Japan and could uninterruptedly lend their Good Offices to the Empire. This, in turn, meant that bilateral relations between Stockholm and Tokyo took their "regular" course with trade unfolding, diplomats stationed in both capitals, telegrams being sent back and forth, and both governments in constant negotiation over their respective interests.

Because of this experience of diplomatic continuity, this book uses key moments of Japan's wartime experience to separate different stages of the bilateral relationship. It begins with events in China where the "Mukden Incident" on September 18, 1931, marked the beginning of Japan's violent expansion into Asia that ended only with the Empire's surrender to the Allied forces on September 2, 1945. Especially in Japan, this is not an uncommon periodization. The term "fifteen-year war" (jügonen sensō) was coined by Tsurumi Shunsuke. ${ }^{28}$ It is used by notable historians, for instance, Fujiwara Akira, Imai Seiichi, Eguchi Keiichi, and Hotta Eri, and features in textbooks or museums that put more stress on Japan's expansion into Asia than on its belligerency in the Pacific. There are also US scholars who are not fond of the Eurocentric periodization of World War II. The eminent Harvard Japanologist and later ambassador to Japan (19611966), Edwin O. Reischauer, for example, argues that World War II "really" started in 1937 at the Marco Polo Bridge. ${ }^{29}$ The idea of a "fifteen-year war" is not without its critics. ${ }^{30}$ However, it is a useful concept for this book because it captures Sweden's long and continued involvement with "violent Japan," which, according to the foreign diplomats who experienced it, was markedly different from earlier and later periods. ${ }^{31}$ Consequently, we are using the term of the Long Second World War to capture this distinctive period of Swedish neutrality as it offers an answer to the question "neutral toward what?"-neutral toward Japan's 15 years of belligerency.

Concretely, we use moments that were important to Japan as sub-periodization for the chronological account of events. After a brief introduction outlining 
the beginnings of Swedish-Japanese relations in Chapter 2, the next section deals with the events of 1931, Japan's blunders in Manchuria, the resulting fallout with the League of Nations, and Sweden's position inside this political community that tried (unsuccessfully) to stop Japan's expansionist course. The account ends with the failure of the League system and the implications thereof for Stockholm and Tokyo. Chapter 4 discusses events after the Marco Polo Bridge incident, in 1937, which is today known as the "official" outbreak of the Second SinoJapanese War. It changed Swedish attitudes toward East Asia and impacted its trade and diplomacy. Those developments were amplified by the outbreak of war in Europe, in 1939, as will be shown in Chapter 5. The attack on Pearl Harbor in late 1941 marks the next stage of this book in Chapter 6. Finally, Chapter 7 is an essay by Bert Edström in which he chronicles meticulously the "Bagge Maneuver" that unfolded in late 1944 and early 1945, which marked an extraordinary moment of Sweden's neutral diplomacy, shortly before the end of the Long Second World War.

\section{Wartime diplomacy}

Besides neutrality, the other vital component to understand Sweden's wartime bilateral relations with Japan is its capacity as a diplomatic actor. Despite Sweden's relatively small size, with a population of only 6.3 million in 1938 , the country had a sovereign and independent foreign policy for which it could count on a well-trained and well-established corps of diplomats to represent its interests around the world. That set Sweden apart from other actors of the Long Second World War, when large parts of the globe were still colonized. Indonesia was not born yet but administered as the "Dutch East Indies" by the Netherlands. The Philippines, too, was under US colonial control. Washington had taken the archipelago off the hands of the Spanish in the 1898 US-Spanish war, at about the same time as it gobbled up the neutral Kingdom of Hawaii. ${ }^{32}$ Taiwan and Korea were dependencies of Japan, while Indochina, the Indian subcontinent, parts of Arabia, and nearly all of Africa was ruled by the British, Dutch, French, Spanish, Portuguese, Germans, or Italians. Their territories did not have statehood and thereby no foreign policy or diplomacy.

Other nations were too young, too small, or too poor to sport effective foreign services. The newly independent (1922) Irish Free State, for example, had simply not had the time to build a corps of diplomatists who could have represented its interests in the Far East by the time warfare began. Although Ireland also remained neutral, it had no diplomats stationed in Japan, nor had it yet fostered economic ties with the Empire. Diplomatic relations were established only in 1957. Other sovereign neutral States like Andorra, Monaco, or San Marino also had no presence in Japan due to their minuscule size. The only exception was the Vatican who, despite being a city-state, had such a long diplomatic tradition that it even stationed official representatives in Japan and China where Pope Pius the XII tried to safeguard the interests of Catholics during the war. ${ }^{33}$ South American neutrals, on the other hand, were large and had been independent since the early 
nineteenth century. But many of them had not had economic interests on the other side of the Pacific and hence did not maintain many diplomatic ties. Brazil and Argentina were two exceptions. The former had had diplomatic relations with Japan since 1895, but it severed all contacts in 1942 after declaring war on Germany and Italy (although it only declared war on Japan on June 6, 1945). Argentina, on the other hand, remained neutral for a long time and even had diplomatic relations with Japan on ambassadorial level. However, its ambassador, Rodolfo Moreno, was absent from Japan when the Pacific War broke out and was unable to return. In addition, the chargé d'affaires had only meager resources to work with, which made an active diplomatic engagement in Japan impossible after 1941. ${ }^{34}$ In the end, Argentina declared war on Japan on March 27, 1945.

Sweden, on the other hand, was in a completely different position. Not only did it operate five consulates distributed over the Japanese Archipelago, but also maintained diplomatic outposts (legations or consulates) in most of Japan's enemy countries. This led to Sweden serving as the second-largest Protecting Power of World War II (after Switzerland), providing so-called Good Office services. Initially, this meant little to Japan. During its military campaigns in China, Stockholm was more of a nuisance than an asset to Tokyo because of Sweden's actions at the League of Nations. But once the War in the Pacific began Swedish Good Offices became an important factor in Japan's wartime foreign policy. Being a Protecting Power and rendering Good Office services meant assuming diplomatic functions of a belligerent state on enemy territories. To name only one instance, Sweden became the diplomatic representative of the Netherlands in Japan. The Swedish mission took over all functions usually performed by the Dutch embassy. It cared for the safety of Dutch diplomats and civilians, negotiated with Tokyo on behalf of the Netherlands, forwarded Dutch protests, and performed all civil consular duties toward Dutch subjects in Japan, for example, the officiation of marriages or the notarization of death certificates. The rendering of Good Office services by neutral states had been a common practice for centuries and was not considered a breach of neutrality because it was-and still is-in conformity with customary international law and was protected by Article 18(b) of the Second Hague Convention of 1907..5 Besides, Sweden rendered Good Office services with the consent of both belligerent parties. This is only natural as any neutral could only act on behalf of an enemy country if the host country accepted that. In the case of the Netherlands, the Japanese Ministry of Foreign Affairs (Gaimushō) explicitly acknowledged and allowed Swedish representation of Dutch interests on its territory. In return, the Netherlands accepted that Sweden would represent Japanese interests on its territory (or, rather, toward its government in exile, as the Netherlands was occupied by Germany from May 1940 onward). Especially in sensitive areas like Hawaii or for the coordination of Prisoners of War (PoW) exchanges, Swedish assistance became a valuable asset to the Japanese Government.

It would be an overstatement to claim that Tokyo "depended" on neutral Good Offices, but from the available records it permeates that the Gaimushō valued Swedish assistance and that some of its exponents even trusted that the 
Swedish Minister could be depended on to initiate peace talks between Japan and the Allied Powers. For the purposes of this book, it simply means that Sweden could interact with Japan during the entire time of the war. However, that does not explain why it would choose to do so. To understand that, it is imperative to know what brought Sweden and Japan together in the first place.

\section{Notes}

1 Gerhard Krebs, "Aussichtslose Sondierung. Japanische Friedensfühler und schwedische Vermittlungsversuche 1944/45," [Hopeless probing. Japanese peace feelers and Swedish mediation attempts 1944/45], Vierteljahrshefte für Zeitgeschichte 45, no. 3 (1997): 430-431.

2 Bagge served twice in Tokyo, as First Secretary from 1928 to 1931 and as Minister Plenipotentiary and Extraordinary from 1937 to 1945. See Chapter 4.

3 On Japanese plans for the domination of East Asia, see John W. Dower, War without Mercy: Race and Power in the Pacific War (New York: Pantheon Books, 1986).

4 Spain broke relations with Japan in April 1945 but never declared war on Japan.

5 The Spanish case has been researched by Florentino Rodao in his seminal work Franco y el Imperio Japonés [Franco and the Japanese Empire] (Barcelona: Plaza \& Janés, 2002). The Swiss and the Spanish cases are both analyzed in Pascal Lottaz, "Neutral States and Wartime Japan: The Diplomacy of Sweden, Spain, and Switzerland toward the Empire," (PhD diss., National Graduate Institute for Policy Studies, 2018). A monograph on the Swiss case by Lottaz is forthcoming.

6 See for example the criticism levied by Christian Leitz, Sympathy for the Devil: Neutral Europe and Nazi Germany in World War II (New York: New York University Press, 2001).

7 Maria-Pia Boëthius, Heder och samvete: Sverige och andra världskriget [With honor and conscience: Sweden and the Second World War] (Stockholm: Norstedt, 1991).

8 On Swedish involvement in European colonialism, see Aryo Makko, European Small States and the Role of Consuls in the Age of Empire (Leiden: Brill, 2020).

9 Statistiska Centralbyrån, Statistisk årsbok för Sperige, 1938 [Central Office for Statistics, Statistical Yearbook for Sweden, 1938], 169.

10 Ibid.

11 Although trade shrank to almost nothing during the last years of the war when shipments could no longer pass Allied blockades, Swedish piano wire (used in the wings of Japanese warplanes) still found its way to Japan on board of German submarines.

12 There are vivid memories from diplomats stationed in Tokyo about the harsh way in which the public and especially the military treated foreigners-even when they belonged to neutral countries. See on this, for example, the memoirs of the Swiss Minister to Japan: Pierre Yves Donzé et al., eds., Journal d'un Témoin: Camille Gorgé, diplomat Suisse dans le Japon en guerre 1940-1945 [Journal of a witness: Camille Gorgé, Swiss diplomat in wartime Japan], vol. 10, Quaderni di Dodis (Berne: Diplomatic Documents of Switzerland, 2018), 31.

13 Bagge to UD, Report, August 9, 1940 (UDA, 2210.03.1, HP1, Xj, XIII-XV).

14 Bagge to UD, Telegram, August 30, 1941 (BA, 230033.2, E2, I).

15 The two most notable scholars in this field are the German Professor Gerhard Krebs and the Swedish Historian Bert Edström thanks to whom some of the more prominent episodes of Sweden's interactions with Japan have already been uncovered. See: Krebs, "Aussichtslose Sondierung"; Bert Edström, "Japan as 


\section{Introduction}

a Distant Friend: Scandinavian Countries Adjusting to Japan's Emergence as a Great Power," in The Decade of the Great War: Japan and the Wider World, ed. Tosh Minohara, Tze-ki Hon, and Evan Dawley (Leiden: Brill, 2014), 211-230.

16 The sources for the national debates of the two countries are mostly derived from the white books, government statements, newspaper articles, and the records of parliamentary debates. Trade records are mostly based on the Swedish statistical yearbooks and diplomatic correspondence between the legation in Tokyo and the Ministry for Foreign Affairs. The same sources, together with various memorandums, telegrams, and letters from the legation are also the basis for the accounts of Sweden's diplomacy and foreign policy. The most important archive for this work is located in Sweden. Documents from and to the Ministry for Foreign Affairs (Utrikesdepartementet) are stored in the main building in Marieberg, in the center of Stockholm. The legation documents, on the other hand, are kept in Arninge (a town adjacent to Stockholm), in the so-called "Missions Archive" (Beskickningsarkiv). Both locations have important holdings but the one in Arninge stores all the correspondence from and to the Swedish legation in Tokyo and has therefore been more yielding to this study. Unfortunately, some of the diplomatic correspondence was lost when the legation caught fire during an air raid and partially burned down on May 26, 1945, see Ericson to Yokohama Consulate, Letter, July 3, 1945 (BA, 230033.2, E4, IV). Therefore, not all records are preserved. Most saddening is the loss of the quarterly reports of the legation for the year $1940(\mathrm{Q} 1 \& \mathrm{Q} 2)$ and the years 1944 and $1945(\mathrm{Q} 1-\mathrm{Q} 4)$. The surviving quarterly reports for the years 1939-1946 can be found in UDA, 2210.03.1, HP 1, Xj, XIV-XVIII.

17 As cited in Alf W. Johansson and Norman Torbjörn, "Sweden's Security and World Peace," in Creating Social Democracy. A Century of the Social Democratic Labor Party in Sweden, ed. Klaus Misgeld, Karl Molin, and Klas Åmark (Pennsylvania: Pennsylvania State University Press, 1992), 345. See also Mikael af Malmborg, Neutrality and State-building in Sweden (New York: Palgrave, 2001), 133.

18 The document was a draft for a circular letter to the main Swedish legations. However, for unknown reasons, it was never sent out. The document is cited in Wilhelm M. Carlgren, Svensk utrikespolitik 1939-1945 [Swedish foreign policy, 1939-1945] (Stockholm: Allmänna Förlaget, 1973), 13-14. In English see John Gilmour, Sweden, the Swastika and Stalin: The Swedish Experience in the Second World War (Edinburgh: Edinburgh University Press, 2010), 15.

19 Gunnar M. Hägglöf, "A Test of Neutrality: Sweden in the Second World War," International Affairs 36 (1960): 160.

20 Gilmour, Sweden, the Swastika and Stalin, 113-115.

21 Malmborg, Neutrality and State-Building in Sweden, 142.

22 Something that has led to the argument that Swedish foreign policy was more reactive than proactive, see Gilmour, Sweden, the Swastika and Stalin, 28.

23 Malmborg, Neutrality and State-Building in Sweden, 142.

24 Gilmour, Sweden, the Swastika and Stalin, 45-56.

25 Ibid., 67.

26 Ibid., 25-26.

27 Neue Zürcher Zeitung, "Die Japanische Neutralitätspolitik" [Japanese neutrality policy], September 6, 1939.

28 Shunsuke Tsurumi, "Chishikijin no sensō sekinin" [The intellectuals' responsibility for the war], Chūō kōron 71, no. 1 (January 1956). For an English discussion, see Shunsuke Tsurumi, An Intellectual History of Wartime Japan (London: KPI, 1986).

29 Edwin O. Reischauer, Japan: The Story of a Nation, 4th ed. (New York: Alfred A. Knopf, 1990), 170. For the use of Long Second World War see e.g. Richard 
James Boon Bosworth, Explaining Auschwitz and Hiroshima: History Writing and the Second World War 1945-1990 (London: Routledge, 1993), 6. See also Mark Edele, The Soviet Union: A Short History (New Jersey: Wiley Blackwell, 2019), 123-144.

30 Sandra Wilson, "Rethinking the 1930s and the '15-Year War' in Japan," Japanese Studies 21, no. 2 (2001).

31 See, e.g., the recollections of Switzerland's wartime Minister to Japan, Camille Gorgé, who in 1964 argued that he had seen "three Japans" throughout his lifetime. Camille Gorgé, "Les Trois Japons" [The three Japans] in Nippon-Helvetia, ed. Comité du Centenaire (Tokyo: Akatsuki Insatsu, 1964).

32 David Keanu Sai, "Hawaiian Neutrality: From the Crimean Conflict through the Spanish-American War," Paper presented at the University of Cambridge, UK, Centre for Research in the Arts, Social Sciences and Humanities, Sovereignty and Imperialism: Non-European Powers in the Age of Empire (September 10-12, 2015).

33 Pascal Lottaz and Florentino Rodao, "The Vatican, WWII, and Asia: Lessons of Neutral Diplomacy," in Notions of Neutralities, ed. Pascal Lottaz and Herbert Reginbogin (Lanham: Lexington, 2019). See also Olivier Sibre, La Saint-Siège et l'Extrême-Orient (Chine, Corée, Japon): De Léon XIII à Pie XII (1880-1952) [The Holy See and the Far East (China, Korea, Japan): From Leo XIII to Pius XII (1880-1952)] (Roma: École Française de Rome, 2012).

34 Lottaz, "Neutral States and Wartime Japan," 373-377.

35 On Good Office and Protecting Power mandates, see David Dunlop Newsom, Diplomacy under a Foreign Flag: When Nations Break Relations (London: Hurst \& Company, 1990). 


\section{In the beginning Early Swedish-Japanese relations}

Swedish-Japanese relations date back to the time when Stockholm and Kristiania (Oslo) were still under the same king. The United Kingdoms of Sweden and Norway was the twelfth country to establish diplomatic relations with Japan after the archipelago's 250 years of relative ${ }^{1}$ seclusion from the world. ${ }^{2}$ Just as in the case of Japan's contacts with other Western powers, the relations to Sweden underwent a rather amazing metamorphosis. Originally treated as a backward and weak Asiatic country, Japan later entered the Great Power club, joining Great Britain, France, Russia, and the United States. From around 1895, the country was considered to be the dynamic force in the East, a state that played in a different league from a small power like Sweden. Some also viewed it as a dangerous future economic competitor. This was due to the resolute Japanese modernization experiment, accomplished in one generation, and the victorious wars against China (1894-1895) and Russia (1904-1905).

When China and Japan were "opened" to Western interests during the years after the Opium War (1839-1842) and Commodore Matthew C. Perry's ultimatum to Japan in 1853, grand hopes for the potentially enormous East Asian market were born in many sectors of the Swedish trade and shipping industries. At the end of the 1850s, the Swedish and Danish governments, following Perry's example, even discussed dispatching an armed naval expedition to obtain a treaty of amity and commerce from Japan. However, these plans of "practical Scandinavianism" were shelved. ${ }^{3}$

Although Sweden did not belong to the first round of seafaring nations to approach Japan after its forceful opening, it was the first country to conclude a treaty with the new Meiji Government after the demise of the Tokugawa Shogunate. ${ }^{4}$ Sweden did not send its own embassy to Japan to negotiate the terms of the agreement, because it was, in essence, the same document that the other Great Powers and Switzerland had already concluded, granting more rights to the Western powers than to Japan and included a most-favored-nation clause. ${ }^{5}$ The treaty was signed on November 11, 1868, by the Minister Resident of the Netherlands, Dirk de Graeff van Polsbroek. The document was one among a number of such "unequal treaties" that East Asian nations were forced to accept during these decades. It conferred extraterritoriality on Swedish and Norwegian citizens at the same time as it deprived Japan of the right to set its own tariffs. ${ }^{6}$

DOI: $10.4324 / 9781003182061-2$ 
Sweden was even given the right to "inspect trade" by sending warships into Japanese territorial waters. ${ }^{7}$ It is doubtful, however, that the Swedish Navy ever made use of this right. Despite these favorable conditions, Swedish interest in Japan remained relatively low. Stockholm, for example, did not name a SwedishNorwegian national as its diplomatic representative for nearly 40 years. ${ }^{8}$ The UD left its diplomacy to Dutch (and occasionally Spanish) ministers, who lent their Good Offices to the Scandinavians. It was not until 1906 that a proper Swedish minister was chosen to handle diplomatic relations with Japan. ${ }^{9}$

Also, Japan at first had no diplomatic representation in Stockholm. Only in 1880 the Japanese envoy to St. Petersburg was side-accredited to Sweden. It took another 25 years until the first proper minister extraordinary and plenipotentiary was stationed in Stockholm, due to the outbreak of the Russo-Japanese war in 1904 (during which Sweden remained neutral), when the embassy in St. Petersburg had to be abandoned. From that point onward, the responsibilities of the Japanese Minister to Stockholm were successively broadened; in 1907 he was side-accredited to the legation in Oslo, in 1917 to the one in Copenhagen (which had earlier been subordinated to the Hague), and in 1921 to Helsinki. Slowly, Stockholm grew into the outpost of Japan's entire Scandinavian diplomacy.

Table 2.1 Swedish representatives to Japan 1871-1945

\begin{tabular}{|c|c|c|c|c|}
\hline First Name & Last Name & Position & From & To \\
\hline $\begin{array}{l}\text { Frederik Philip } \\
\quad(\text { Jonkheer })^{\mathrm{a}}\end{array}$ & Van der Hoeven & Minister R. ${ }^{b}$ & 1871 & 1872 \\
\hline Wilhelm F.H. & Van Wekherlin & Minister R. & 1872 & 1878 \\
\hline $\begin{array}{l}\text { Edmond W.F. } \\
\text { (Jonkheer) }\end{array}$ & $\begin{array}{l}\text { Wttewaal van } \\
\text { Stoetwegen }\end{array}$ & Minister R. & 1879 & 1881 \\
\hline Johannes Jakobus & Van der Pot & Minister R. & 1881 & 1889 \\
\hline Dmitri Louis (Greve) & ${ }^{c}$ Van Bylandt & Minister R. & 1890 & 1896 \\
\hline $\begin{array}{l}\text { Hannibal C.J. } \\
\text { (Jonkheer) }\end{array}$ & Testa & Minister R. & 1896 & 1900 \\
\hline $\begin{array}{r}\text { Hannibal C.J. } \\
\text { (Jonkheer) }\end{array}$ & Testa & Envoy & 1900 & 1902 \\
\hline Arthur M. D. (Baron) & $\begin{array}{l}\text { Sweerts de Landas } \\
\text { Wyborgh }\end{array}$ & Envoy & 1902 & 1905 \\
\hline John (Jonkheer) & Loudon & Envoy & 1905 & 1906 \\
\hline Gustaf Oskar & Wallenberg & Envoy & 1906 & 1918 \\
\hline David Kristian & Bergström & Envoy & 1918 & 1922 \\
\hline Oskar A.H. & Ewerlöf & Envoy & 1922 & 1928 \\
\hline Johan E.E. & Hultman & Envoy & 1928 & 1936 \\
\hline Widar & Bagge & Envoy & 1936 & 1945 \\
\hline
\end{tabular}

Source: Utrikesdepartementet. Kungl. utrikesdepartementets kalender (Stockholm: Almqvist \& Wiksell 1955), 236.

Note: a Dutch noble title for "squire."

b Minister Resident.

"Swedish noble title for "count." 
In terms of commerce, the outcome of the 1868 treaty was rather inconsequential. Neither trade nor shipping yielded any substantial profits. While there was a clear lack of effort on the Swedish side, the Japanese viewed the trade agreements - signed under pressure — as a national misfortune that all Japanese statesmen of the new Meiji period sought to correct as soon as possible. The universal desire for treaty revision on the part of Tokyo became an important catalyst for Japan's successful developmental policy. It was one of the motives behind the mission of the Foreign Minister (gaimukyō), Prince Iwakura Tomomi, to visit the United States and Europe in a unique diplomatic tour de force of 20 months (1871-1873). The group of some 50 emissaries also visited Sweden for one week, during which the Swedish Government used a large sum of money to accommodate the high-ranking guests at its expenses, showing a genuine interest in developing its relationship with Tokyo. The Japanese proposal for treaty revision, however, was rebuffed in Stockholm, as in all other Western capitals. ${ }^{10}$ The efforts from the mission and the desire to modernize Japan resulted in a domestic program for industrialization which, in turn, gave Japan more leverage for its demand for fairer bilateral relations. Finally, in 1896, the treaty was renegotiated. The new version represented a big step toward full equality. When the last restrictions were removed in 1911, a symbolic end to Japan's humiliations of the nineteenth century was reached. ${ }^{11}$ Ironically, modernized Japan fully adopted Western-style colonial policies, ruling over Korea and Taiwan, and even arranging its own unequal treaties with China.

Meanwhile, in Stockholm, Japan remained a relatively minor concern. The diplomatic and economic neglect had to do with Sweden's foreign policy objectives, which did not include competing with great colonial powers on international markets. There were also strong Swedish stereotypes about Japan being a backward Asiatic country. These perceptions only changed when the Empire entered the club of Great Powers and became comparable to heavyweights like Britain, France, Russia, and the United States. Only from around 1895, Swedish diplomats and statesmen started to consider Japan as a dynamic force in the East, with a change in the national attitude toward it following a decade later. ${ }^{12}$

\section{The impact of 1905}

The year 1905 unexpectedly turned into one of the most important years for Sweden's foreign policy in the young twentieth century. For one, its union with Norway ended when first the Norwegian parliament and then the population voted for independence. The new proportions of Sweden changed the strategic considerations of Stockholm significantly. Long forgotten were the days when the country was a major power to be reckoned with. ${ }^{13}$ Embedded in a European context of increasingly large, imperialistic nation-states, with Germany and Italy unified, Sweden had become a small power, giving an impetus for a more proactive diplomacy around the globe. ${ }^{14}$

In 1905, Japan also won an important military victory over Tsarist Russia that marked the moment when the Tenno's Empire definitely rose to the status 
of a Great Power in the eyes of many Swedes. It was the first-ever victory of an Eastern army over a European state in modern times. Some contemporaries commented on this surprising feat positively, as it was the "under-dog" who won the confrontation. Authoritative writers like Sven Hedin, Hjalmar Cassel, and Rudolf Kjellén published books that painted a picture of Japan as the "docile" pupil of the West and the guarantor of stability and civilization in the East, while also depicting it as immature and imitative. At the same time, both Cassel and Kjellén (and, in fact, also Hedin) warned in their books of a "yellow peril," as an economic threat to the whites that the German Emperor Wilhelm II had warned of. Europe would not be able to hold its ground against the cheap labor of East Asians, as the authors predicted. ${ }^{15}$ It was during these years that Lafcadio Hearn wrote his famed books on Japan and its culture, and that Puccini's opera Madame Butterfly aroused international acclaim. The magazine Hvar 8 Dag (Every Eight Days) spoke about "Japan, this in our fantasy so romanticized oriental country of the Mikado, the chrysanthemum and - the geishas." ${ }^{16}$ It is not unlikely that the popularity of this superficially positive image was built by the news media on a wish to belittle the ongoing Japanese transformation. Perhaps it was a wish to reassure European audiences that the country was still essentially different from the rational and modern Western world.

Nevertheless, when Swedish observers drew comparisons between East Asian countries, Japan was treated as more "normal," that is, influenced by the occident, than its immediate neighbors. In the standard discourse, it was presented as a stark contrast to China that was seen as xenophobic, barbaric, and reactionary. This image was established and accepted already well before the Boxer Rebellion of 1900. A typical Swedish East Asia travelogue from 1893 put it in this way:

What a tremendous difference between Japan and China! In the one place everything is neat and tidy, in the other it is dirty and smelly. In one country everything is bright and jolly, in the other it is somber and restricted. Here you are welcomed and everywhere kindly received, there you are viewed with a slanted gaze (in every sense of the word) and you know you are hated, regardless of whether the sly Chinese show it openly or not. ${ }^{17}$

The internal and external transformation of Japan aroused conflicting sentiments in Sweden, as well as in other Western countries. It created the ambivalence that was typical for European and American attitudes toward the Japanese and Chinese in the early twentieth century.

Also in terms of trade, 1905 became a watershed moment. Sweden had certain advantages on the world markets in the form of domestically produced advanced technology, and since one-sided treaties enforced through gunboat diplomacy were fading away, a new foreign trade strategy began to take shape. Right after the dissolution of the union with Norway, a specially appointed committee on diplomatic and consular matters refocused Sweden's foreign policy on the promotion of trade and commerce. By concentrating on the export of high-quality products, Swedish traders would gain a qualitative advantage over foreign rivals. ${ }^{18}$ 
The committee took the decision to put more emphasis on relations with Asia, because for the new approach to succeed, regional trade hubs became a necessity to access foreign markets. ${ }^{19}$ Unlike Denmark, which chose to base its Eastern diplomatic headquarters in China, the Riksdag decided in accordance with the proposal launched by the committee to make Japan its hub in Asia. The military might of the Empire and the already existing Swedish diplomatic network there made it an attractive option. ${ }^{20}$ In 1907, Dan Broström's Swedish East Asia Company opened a regular sea route between Gothenburg and Yokohama with intermediary stops in China. Another typical trend was the founding of Swedish trading firms in the Far East. For instance, Knut Gadelius commenced his activities in Japan also in 1907. He was soon followed by others, but Gadelius would always maintain a special position. ${ }^{21}$ His company has been described as Sweden's first real corporation in the machine export branch and a Japanese observer later claimed that no foreign enterprise had introduced so many new engine types and production methods to his country. ${ }^{22}$

At the same time, the committee's report resulted in an overhaul of the Swedish foreign service, opening it up to non-aristocrats, and thereby broadening the choice of envoys. ${ }^{23}$ In 1906, Sweden's Foreign Ministry named Gustaf Oskar Wallenberg its first proper envoy extraordinary and minister plenipotentiary to Japan. ${ }^{24}$ Wallenberg was an influential local ship owner and belonged to Sweden's most prominent families of financers. His half-brother, Knut Wallenberg, would become Sweden's foreign minister for most of World War I, 1914-1917, and his grandson was the famous Raoul Wallenberg who saved tens of thousands of Jews from deportation by the Nazis in Hungary. ${ }^{25}$ Gustaf Wallenberg was a new kind of diplomat, a businessman who had become convinced of the immense future potential of the East Asian market. From the beginning of his mission to Tokyo, he went beyond considerations for diplomatic relations with Japan alone. His task was to increase Swedish trade with Asia in general. Especially China promised large gains for a small export-oriented nation if just the right mode of interaction could be established. Bert Edström put it as follows:

With one quarter of the world's population, China had enormous needs that the Japanese industry could meet. The logic was that if Sweden could become a supplier to Japan, then it would automatically result in an upsurge in Swedish exports as a result of the rapid growth of Japan's exports. ${ }^{26}$

Wallenberg was consequently side-accredited to China in 1907, a year after his arrival in Japan. ${ }^{27}$ For an entire decade, he was a towering figure in the Swedish commercial campaign in East Asia. Displaying endless optimism, he made sustained efforts to gain a foothold for Swedish companies in both countries. He transformed the legation into a trade agency for pig-iron, pulp, and similar commodities. After all, the prospects for Swedish trade with Japan and China were good in both cases. The local population was more inclined to seek out small European powers for questions of trade and knowledge transfer instead of the 


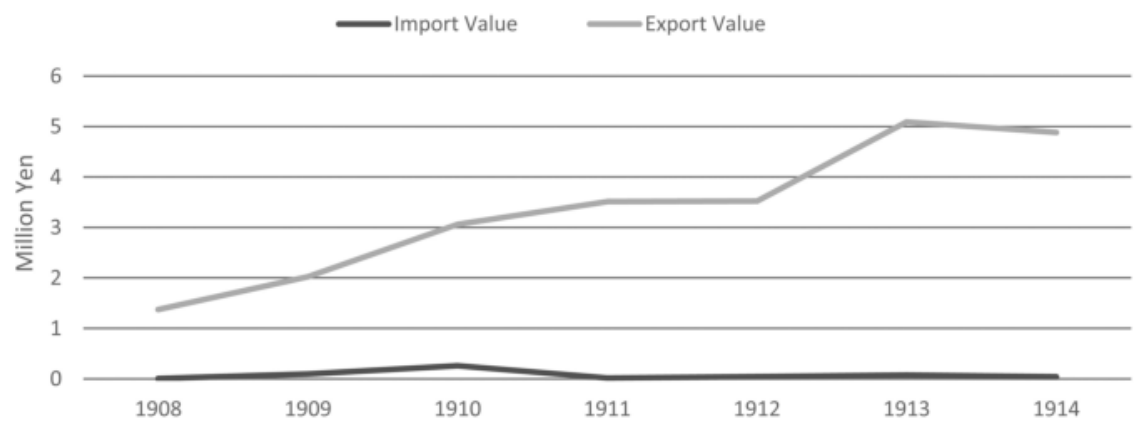

Figure 2.1 Swedish imports and exports to Japan 1908-1914. Note: In million yen. Source: Centralbyrån. "Levnadskostnadsindex/KPI."

large, imperialistic nations with whom both had already made experiences of being forced into unequal relationships. ${ }^{28}$

The new trade strategy was relatively successful. Between 1908 and 1914 Swedish exports to Japan almost tripled from KR 2.27 million to KR 6.32 million. ${ }^{29}$ The low inflation rate of just above 1 percent (on average) signified a real growth of exports and not just an increase on paper. ${ }^{30}$ By 1911, Sweden had conquered a position as the fifth biggest European exporting nation to Japan. The same could not be said about imports; except for sulfur, tea, silk, and some "oriental curiosities," merchandise from Japan was for a long time insignificant and usually managed by German middlemen. ${ }^{31}$ Comparing import and export values, based on Japanese statistics, shows the disparity clearly.

It must be added, however, that Swedish and Japanese statistics at the time were kept according to the "country-of-purchase" method rather than "countryof-origin," which meant that the very modest figures of imports of Japanese commodities are unrealistically low. In all likelihood, a substantial part was procured by other ways than through direct trade. Yet, it is clear that Sweden ran a significant trade surplus with Japan.

\section{From the Great War to the interwar period}

The outbreak of the Great War caused inevitable disarray, affecting Swedish maritime lines of communication to Japan. However, at times when shipments were possible, they carried goods of higher value, leading to an actual increase in gains from trade. That is not least due to the disappearance of Germany as a Japanese trading partner, leaving the field open to its neutral competitors. For Sweden, this meant that despite the European fighting, the positive trade relationship with Asia could continue. At the end of Wallenberg's tenure, in 1918, exports to Japan had again more than doubled to KR 13.11 million. ${ }^{32}$ Since the Great War in Europe caused considerable inflationary tendencies, not all of the revenue increase of that period stems from an actual increase in exported products. ${ }^{33}$ Especially in the last 
two years of the war, the Swedish economy suffered from large increases in the general price level of goods and services. ${ }^{34}$ Nevertheless, even with this qualification, it is evident that the Swedish trade strategy and Wallenberg's diplomacy succeeded in attracting more currency from Japan in payment for Swedish goods. Trade relations beneficial to Sweden were on the rise.

It was only after World War I that Swedish-Japanese trade significantly slowed down for the first time. Although this was a period of readjustment and a return to "normal" pre-war trade activities, the 1920s did not see the same slow but steady growth of exports that the previous decade did. It was, all in all, a period of slight decline. Only in the late twenties did imports begin to rise again from their previously low levels. In absolute and relative terms, trade was very limited prior to 1930 , and even the sales of goods and services would not exceed 1 percent of the total Swedish export value (Table 2.2 shows the situation in 1928).

Still, Sweden's corporate world directed considerable attention to the Far East, as it realized the large market potential of the region with its populous nations. Reports about Japan's swift industrial modernization predicted that the country would become an ever more important actor in the global economy. ${ }^{35} \mathrm{In}$ spite of the inconspicuous trade volume, Japan was Sweden's foremost customer outside the West (in terms of turnover) according to statistics from 1931. From a Swedish commercial viewpoint, Japan was always a more important market than China. Conversely, Sweden was also Japan's major Scandinavian trading partner, even if it played only a marginal role in comparison with clients such as the United States and China. ${ }^{36}$ Sweden's most successful export items were paper, pulp, iron, steel, and modern machine technology.

It is unclear how much of Swedish exports to Japan were destined for reexport or became part of new products exported to mainland Asia. Either way, the Swedish strategy to foster export markets in Asia succeeded at least partially. In comparison with its competitors, it is also safe to say that among the Scandinavian

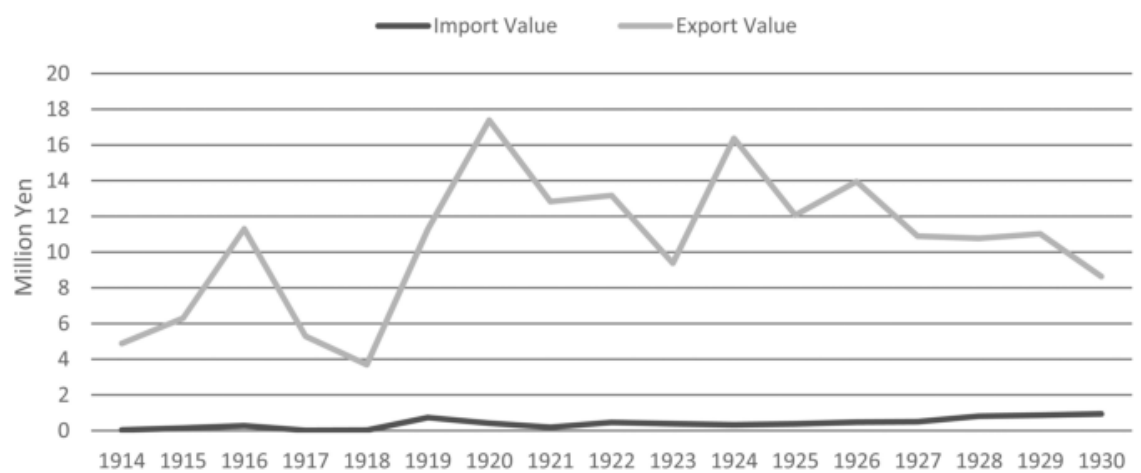

Figure 2.2 Swedish imports and exports to Japan 1914-1930. Source: Ryūshi Honma, ed. Nihon keizai tōkeishū 1868-1945 [Japanese economic statistics, 1868-1945] (Tokyo: Nichigai Associates, 1999), 40. Note: In million yen. 
Table 2.2 Swedish trade with selected countries in 1928 and 1938

\begin{tabular}{|c|c|c|c|c|c|c|c|c|}
\hline & \multicolumn{4}{|l|}{1928} & \multicolumn{4}{|l|}{1938} \\
\hline & Import & $(\%)$ & Export & $(\%)$ & Import & $(\%)$ & Export & $(\%)$ \\
\hline Germany & 530.51 & $(31.06)$ & 198.46 & $(12.60)$ & 442.86 & $(21.41)$ & 328.79 & $(17.88)$ \\
\hline USA & 275.77 & (14.74) & 165.96 & $(10.54)$ & 336.28 & $(16.26)$ & 164.88 & $(8.97)$ \\
\hline UK & 275.62 & (16.14) & 399.85 & $(25.39)$ & 251.26 & $(12.15)$ & 426.08 & $(23.17)$ \\
\hline France & 59.06 & $(3.46)$ & 90.07 & $(5.72)$ & 62.36 & $(3.02)$ & 59.05 & $(3.21)$ \\
\hline Japan & 1.25 & $(0.07)$ & 15.63 & $(0.99)$ & 16.44 & $(0.80)$ & 26.31 & $(1.43)$ \\
\hline USSR & 8.70 & $(0.51)$ & 30.40 & (1.93) & 9.30 & $(0.45)$ & 17.54 & $(0.95)$ \\
\hline Total & 1,707 & & 1,575 & & 2,068 & & 1,839 & \\
\hline
\end{tabular}

Source: Centralbyrån, Statistisk årsbok 1929, 158-159, and 1939, 168-169.

Note: In million crowns.

Table 2.3 Structure of the Swedish exports to Japan in 1928

\begin{tabular}{lr}
\hline Category & Export Value \\
\hline Woolen machine felt & 268,709 \\
Tallow, oils, tar, etc. & 14,998 \\
Lathe-turned and other products (not exceeding 2kg) & 43,206 \\
Pulp & 820,756 \\
Cardboard & 27,446 \\
Newsprint & 883,388 \\
Other sorts of paper & $4,087,094$ \\
Potassium and sodium chlorate & 326,398 \\
Chemical-technological preparations & 507,102 \\
Iron, steel, and metal plate & $3,687,747$ \\
Metalwork & $3,228,301$ \\
Machines and devices of which & \\
$\quad$ Pumps, etc. & 129,098 \\
$\quad$ Roller- and ball-bearings & 966,671 \\
Water and steam turbines & 570,968 \\
Other & 91,145 \\
Total & $15,630,734$ \\
\hline
\end{tabular}

Source: The Official Statistics of Sweden, Commerce, Report for 1928 from the National Board of Trade.

Note: In crowns. The items appear in the order of the official statistics. 
Table 2.4 Swedish trade with Japan 1928-1932

\begin{tabular}{lllll}
\hline Year & Imports & $(\%)$ & Exports & $(\%)$ \\
\hline 1928 & $1,253,615$ & $(0.07)$ & $15,630,734$ & $(0.99)$ \\
1929 & $1,917,663$ & $(0.11)$ & $15,578,518$ & $(0.86)$ \\
1930 & $4,231,382$ & $(0.26)$ & $10,992,164$ & $(0.71)$ \\
1931 & $2,911,773$ & $(0.21)$ & $14,035,791$ & $(1.25)$ \\
1932 & $3,615,383$ & $(0.31)$ & $12,769,967$ & $(1.35)$ \\
\hline
\end{tabular}

Source: The Official Statistics of Sweden, Commerce, Reports for 1928-1932 from the National Board of Trade.

Note: In crowns. Percentages in brackets indicate the ratio of Sweden's total imports and exports, respectively.

Table 2.5 Japanese trade with Sweden 1928-1932

\begin{tabular}{ccc}
\hline Year & Exports to Sweden & Imports from Sweden \\
\hline 1928 & 812,750 & $10,766,854$ \\
1929 & 864,661 & $11,025,186$ \\
1930 & 939,090 & $8,634,489$ \\
1931 & $1,239,769$ & $8,580,826$ \\
1932 & $1,610,281$ & $9,826,582$ \\
\hline
\end{tabular}

Source: Tōyō Keizai Shinpōsha, Nihon bōeki seiran (Tokyo: 1935).

Note: In yen.

countries Sweden was the only one that managed to forge substantial bonds with Japan in the first decade of the twentieth century. ${ }^{37}$

Stagnation also befell Swedish-Japanese cultural exchange. During the interwar period, few Japanese resided in Sweden and also the number of Swedes in Japan-mostly businessmen and legation staff-was scant. When the great Kantō Earthquake struck in 1923, some Swedish residents lost their homes and the Swedish consulate in Yokohama was razed. Gadelius and a number of other enterprises suffered from the destruction, but no Swedish citizen was hurt. ${ }^{38}$

Culturally, there were only few opportunities for bilateral activities. In the 1920s Sweden was only occasionally visited by high-ranking Japanese dignitaries. The only event worth mentioning was the visit by the Vice-Secretary General of the League of Nations, Nitobe Inazō, a renowned pacifist and popular politician in the Geneva-based organization. Vice versa, the most important Swedish visit to Japan was the stopover in Tokyo of the Swedish Crown Prince and his wife during their world tour in 1926. Prince Gustav Adolf spent over a month in Japan where he met in Tokyo with his counterpart, Prince Regent Hirohito (soon to be emperor), before planting a tree at the C.P. Thunberg memorial in Nagasaki. 
Articles in the Japanese press contributed to increasing goodwill toward Sweden. The semiofficial visit, however, did not carry any political significance. It was clouded by the news of a sudden fever that Gustav Adolf caught and by rumors concerning a Chinese knife attack at the British embassy during the lunch for the Crown Prince there. ${ }^{39}$ In August 1930 Prince Takamatsu, the younger brother of Hirohito, with consort paid a return visit to Stockholm, taking the opportunity to inspect the big exposition that the city held in that year. ${ }^{40}$

Diplomatically, Swedish-Japanese relations prospered at the beginning of the century. In a telling interview for the newspaper Chügai Shögyō Shinpō, Japanese envoy, Hioki Eki, wrote that the Japanese were particularly well received in Sweden since 1905 because of the traditional Swedish dislike of Russia, and he added that his country had received "extremely important intelligence" from the Stockholm legation during the Russo-Japanese conflict. Yet Japan's status as a member of the Entente also led to friction with neutral states. In 1918 Envoy Wallenberg was recalled after alleged contacts with the German side (although subsequent investigation exonerated him $).{ }^{41}$ Japan's initiative at Versailles for a declaration on racial equality was met with skepticism by Wallenberg's successor in Tokyo, David Bergström, who had a background as a prominent member of the Swedish Liberal Party and took a reserved attitude to what he considered imperialist nations. ${ }^{42} \mathrm{He}$ was a journalist and former member of parliament, who achieved fame as a public intellectual. His newspaper articles and his work for the introduction of universal suffrage around the turn of the century made him famous among the left-wing liberals-while the conservatives despised most of his policies. Where Wallenberg was a businessman, Bergström was a politician. He was interested in the developments of the Taisho Democracy and the different political institutions that were built during that period. At the same time though, like Wallenberg, Bergström devoted much of his work to improve trade relations. ${ }^{43}$ Revenue from export peaked under his watch.

Bergström was succeeded by Oskar Ewerlöf in 1923. He, too, was a government insider, although from the bureaucratic branch of the administration. He had served as chancellor and head of the Department of Legal Affairs since 1907 and then in the position as state secretary for foreign affairs from 1913 to 1918. Although Ewerlöf was not an industrialist like Wallenberg, or a politician like Bergström, he was no stranger to questions of trade and politics. He had been a member of the State Commerce Commission from 1915 to 1917 and as such he understood the importance of trade negotiations. This proved important for his assignment in Asia where he joined the Special Conference on Chinese Customs Tariff in 1925. ${ }^{44}$ The conference was convened in accordance with the 1922 Washington Naval Conference and the (unequal) Nine Power Treaty, which itself was a vehicle for the United States, Japan, and European powers to cement the Open-Door policy in China. It gave special rights only to Japan in Manchuria but held that all other parts of the country must be equally accessible to all nations who wished to do business there. In return, China was promised that, in the near future, the question of custom tariffs and the principle of extraterritoriality would be renegotiated. That conference took place on October 26, 1925. 


\section{In the beginning}

Sweden was not one of the signatories of the original Nine Power Treaty-it included the United States, Japan, the United Kingdom, Italy, France, Belgium, the Netherlands, Portugal, and China-but, for the follow-up conference, Peking (Beiping/Beijing) extended invitations to other major seafaring nations as well, namely Sweden, Denmark, Spain, and Norway. ${ }^{45}$ Riots and political upheaval in Peking delayed negotiations, and toward the final phase, the conference was deadlocked due to seemingly irreconcilable stances on the country's internal tariff systems. Ewerlöf, together with his Danish colleague, helped to mediate positions during these tense moments. Ultimately, the treaty through which China regained its tariff autonomy after 80 years was completed on November 19, 1926. ${ }^{46}$ For Sweden, the treaty and the status of a guarantor nation to China became important guidelines for its foreign policy toward Asia in later years. ${ }^{47}$

\section{Institutions and decision makers}

In Stockholm, the interwar years were marked by a second wave of reforms to the foreign service, which began to expand. Around 1930, the ministry was organized in three bureaus in charge of political, commercial, and legal questions respectively. Furthermore, there were sections dealing with administration, press, and archives. The ministry became the workplace of about 70 employees. ${ }^{48}$ Foreign policy was mainly handled by the foreign minister and his subordinates without much interference from the rest of the government; prime ministers showed differing degrees of interest in foreign policy. ${ }^{49}$ Foreign ministers were often party leaders, former prime ministers, or other persons with a prominent position in parliament. State secretaries and the heads of the political bureau were also key figures in the making of Stockholm's foreign policy. They wrote memorandums, implemented decisions, and they were the guardians of conversations and written messages that passed through them, giving them much leeway in controlling the flow of information. An important part of the basis for their actions consisted of reports that were regularly sent to Stockholm from Swedish diplomats near and far. All in all, the Foreign Ministry was a rather conservative and traditionalist environment-extant memoirs reveal, for example, that the majority of the staff took a very skeptical view to the "new diplomacy" that was being built on Sweden's membership in the League of Nations. ${ }^{50}$

The breakthrough of democracy in 1918-1921 was accompanied by rising demands for an open foreign policy accountable to popularly elected parliamentarians. In 1921, the Advisory Council on Foreign Affairs, Utrikesnämnden (UN), was formed as a replacement for the earlier Secret Committee. The council was filled with 16 members from all parliamentary parties (except for the communists) who were appointed or reappointed at each annual parliamentary session. It was convoked several times a year for direct reports from the UD. All of its work was done under a vow of secrecy since it operated with highly sensitive international information. In a 12 -month interval, members were given confidential written accounts of events in world politics from the national point of view plus a summary of Swedish foreign policy. In common parlance, these briefs were 
referred to as "White Papers." If a minimum of six councilors desired to discuss a given topic, it had to be put on the official agenda. However, as the name suggests, the council was a purely advisory body without formal power over UD decisions. Independent expertise, built on sources other than those provided by the foreign service, was not used. ${ }^{51}$

The council, thus, did not become as influential as expected. Soon there were fresh demands for less secrecy and the creation of a full-fledged parliamentary committee. That was created in 1937 with the task of preparing foreign policy matters - this time officially and with powers of oversight. The change, however, was not momentous because the members of the new Parliamentary Committee on Foreign Affairs, Utrikesutskottet (UU), were the same people as in the previous Advisory Council. In addition, during debates of foreign policy issues in parliament it had been customary to adopt government proposals without modification - and this pattern remained. ${ }^{52}$ Political institutions might have been changed, but political culture did not follow suit quickly.

As for trade policy, there was an overlap of responsibilities. On the one hand, the UD was responsible for questions related to agreements on trade and navigation, and it was also in charge of international political conferences and the collection of commercial data abroad through the diplomatic offices of Sweden. On the other hand, a separate Ministry of Trade (MOT) had been set up in 1920, which took decisions on issues concerning domestic and foreign trade. At the Trade Minister's side were a cabinet secretary and the head of administration. They were the respective leaders of two separate bureaus within the ministry. The director-general of the National Board of Trade, the organization assigned to promote Swedish commerce, was subordinate to the MOT. Its discussion partners in matters of foreign trade were the relevant interest organizations, among them the Swedish General Association of Exporters (a club of businessmen founded back in 1887) and the various regional chambers of commerce. Principles of trade policy and concrete issues such as tariff bills were frequently discussed in parliament.

\section{Notes}

1 It used to be argued that Japan's "sakoku" period constituted 250 years of Japanese isolation from the world. Recent research questions this narrative. See, e.g., Robert I. Hellyer, Defining Engagement: Japan and Global Contexts, 16401868 (Cambridge: Harvard University Asia Center, 2009); and S. Michael Laver, The Sakoku Edicts and the Politics of Tokugawa Hegemony (New York: Cambria Press, 2011).

2 The first treaty that allowed for diplomacy in that period to happen was signed between Japan and the United States in 1854. The so-called "Treaty of Kanagawa" was rather meager in its content, however. More fleshed out bilateral arrangements followed shortly after. In chronological order of treaty establishment, Japan's first diplomatic relations were with: the United States (58), the Netherlands (58), Russia (58), Great Britain (58), France (58), Portugal (60), Prussia (61), Switzerland (64), Belgium (66), Italy (66), Denmark (67), SwedenNorway (68), Spain (68), North German Confederation (69), Austro-Hungary 
(69), Hawaii (71). See Michael R. Auslin, Negotiating with Imperialism: The Unequal Treaties and the Culture of Japanese Diplomacy (Cambridge: Harvard University Press, 2004).

3 Ingemar Ottosson, "Att framtvinga ett vänskapsavtal - Sverige och Japans öppnande" [Enforcing a treaty of amity: Sweden and the opening of Japan], in Fjärrannära: Kontakter mellan Sverige och Japan genom tiderna [Far and near: Contacts between Sweden and Japan through the ages], ed. Bert Edström and Ingvar Svanberg (Stockholm: Arena, 2001). See, e.g., Aftonbladet (AB), October $6,1859$.

4 Ingemar Ottosson, "Trade under Protest: Sweden, Japan and the East Asian crisis in the 1930s," Center for International Research on the Japanese Economy (Tokyo: 2012), 2.

5 Auslin, Negotiating with Imperialism, 154.

6 Ingemar Ottosson, "Svensk frihandelsimperialism. Det ojämlika fördraget med Japan 1868-1896" [Swedish free-trade imperialism: The unequal treaty with Japan, 1868-1896] Historisk Tidskrift no. 2 (1997).

7 Ottosson, "Svensk frihandelsimperialism." For the original treaty, see "Traktaat van Vriendschap, Handel en Scheepvaart" [Treaty of friendship, commerce and navigation], in Kyū jōyaku isan [Former treaties], ed. Gaimushō Jōyakukyoku (Tokyo: Gaimushō, 1934). The treaty was concluded in Dutch and Japanese.

8 Kawasaki Seirō, "Kenkyū Nōto: Meiji jidai no Tōkyō ni atta gaikoku kōkan (4)" [The foreign missions in Tokyo of the Meiji period (4)] Gaimushō Chōsa Geppō no. 1 (2014), 78 .

9 There are two sources: one from the Swedish and one from the Japanese side. For Sweden, see Utrikesdepartementet, Kungl. utrikesdepartementets kalen$\operatorname{der}$ [Calendar of the Royal Foreign Ministry] (Stockholm: Almqvist \& Wiksell, 1938), 211. And for the Japanese side, see Kawasaki: "Kenkyu Nōto (4)," 78. Interestingly, the Swedish primary source does not mention the short periods during which Spanish ministers represented Swedish interests in 1877 and 1880, as described in Kawasaki's paper which he bases on archival records of the Japanese Ministry of Foreign Affairs. Those were interim mandates taken over by the Spanish mission during the periods when no official Dutch representatives were stationed in Tokyo.

10 Ian Nish, The Iwakura Mission in America and Europe: A New Assessment (London: RoutledgeCurzon, 2004), 1; Bert Edström, "Sweden: 23-30 April 1873, , in ibid., 92, 94-95.

11 Ottosson, "Svensk frihandelsimperialism"; Jan Larsson, Diplomati och industriellt genombrott. Svenska exportsträvanden på Kina 1906-1916 [Diplomacy and industrial breakthrough: Swedish export ambitions in China, 1906-1916] (Uppsala: Almqvist \& Wiksell, 1977).

12 Åke Holmberg, Världen bortom västerlandet: Svensk syn på fjärran länder och folk frain 1700-talet till första världskriget [The world beyond the West: Distant lands and peoples through Swedish eyes from the 18th century to World War I] (Gothenburg: Kungl. Vetenskaps-och vitterhets-samhället, 1988), 477-479.

13 Michael Roberts, Sweden as a Great Power 1611-1697: Government, Society, Foreign Policy (London: Edward Arnold, 1968).

14 Patrick Salmon, Scandinavia and the Great Powers 1890-1940 (Cambridge: Cambridge University Press, 2002), 58.

15 Sven Hedin, Sverige och den Stora Östern [Sweden and the Far East] (Stockholm: Alberts Bonniers Förlag, 1905); Hjalmar Cassel, Det nya Östasien [New East Asia] (Stockholm: Alberts Bonniers Förlag, 1906); Rudolf Kjellén, Den Stora Orienten (Gothenburg: Åhlén \& Åkerlunds, 1911).

16 Hvar 8 Dag, December 24, 1899. 
17 Axel Carlander, Dagboksanteckningar frain resan rundt jorden 1891-1892 [Diary notes from the world tour in 1891-1892] (Gothenburg: Göteborgs Handelstidnings Aktiebolags Tryckeri, 1893), 85.

18 Ottosson, "Svensk frihandelsimperialism," 221-222. The Swedish fear of an "economical yellow peril," for example, manifested itself in the widespread popular belief regarding Japanese espionage in the match factory of Jönköping. That was refuted in Gunnar Cederschiöld and Einar Feilitzen, Den svenska tändsticksindustriens historia före de stora sammanslagningarna [The history of the Swedish match industry before the big mergers] (Stockholm: Natur och Kultur, 1946), 299-300. In this sector, Japan was a serious competitor of Sweden in various Asian markets.

19 Edström, "Japan as a Distant Friend," 219.

20 Ibid.

21 Trading firms such as J. A. Kjellberg \& Söner (Stockholm), Carl Ekman \& Co (Gothenburg) and Bernhard Dieden \& Co (Malmö) followed suit between 1908 and 1910. All of them sold typical Swedish export items such as iron, steel, ballbearings, machines, paper, and pulp. See Sten S:son Ankarcrona, "A Review of the Commercial Relations between Sweden and Japan," in Svensk-Japanska Sällskapets årsskrift [Yearbook of the Swedish-Japanese Association] (Stockholm, 1934).

22 Robert Thune, "Knut Gadelius in Memoriam," in Svensk-Japanska Sällskapets arsskrift 1934, 40-41. He refers to an oral source.

23 Salmon, Scandinavia and the Great Powers 1890-1940, 35-36.

24 There are many books telling the story of the Wallenberg Family, see, e.g. Gunnar Wetterberg, Wallenberg: The Family That Shaped Sweden's Economy (Möklinta: Gidlunds Förlag, 2014).

25 Edström, "Japan as a Distant Friend," 220. Wallenberg took office in Tokyo on January 1, 1907. See: Kawasaki Seirō, "Kenkyū Nōto: Meiji jidai no Tōkyō ni atta gaikoku kōkan (5)" [The foreign missions in Tokyo of the Meiji period (5)] Gaimushō Chösa Geppō no. 2 (2014), 92.

26 Edström, "Japan as a Distant Friend," 222.

27 Bengt Jangfeldt and Harry D. Watson, The Hero of Budapest: The Triumph and Tragedy of Raoul Wallenberg (London: Tauris, 2014), 17.

28 Salmon, Scandinavia and the Great Powers 1890-1940, 36.

29 Centralbyrån, Statistisk årsbok 1914.

30 Calculations based on official Swedish statistics by Statistiska Centralbyrån. "Levnadskostnadsindex/KPI (juli 1914=100), Historiska tal 1830" [Cost of living index since 1830].

31 On this, see Larsson, Diplomati och industriellt genombrott; Ottosson, "Svensk frihandelsimperialism," 221-222; Svensk Export [Swedish Exports], 1907, 415. Wallenberg to UD, February 27, 1907 (UDA, 2210.02, 1K, VII); December 31, 1909 (2210.02, IK, IX); March 14, 1911 (UDA, 2210.02, 103 A 8, I); Japanese Envoy Hata Ryōtarō in Dagens Tidning, June 30, 1920.

32 Centralbyrån, Statistisk årsbok 1923.

33 The inflation of those days sored at times to 23.6 percent.

34 Centralbyrån. "Levnadskostnadsindex/KPI."

35 See, e.g., Svensk Export, "Fjärran Östern på frammarsch" [The Far East advancing], 1931, 187. It is pointed out that Japan has the highest consumption of electricity per inhabitant in the entire world.

36 Tōyō Keizai Shinpōsha, ed. Nippon bōeki seiran [Japanese trade survey] (Tokyo: $1935), 353,63$. Sweden only accounted for 0.45 percent of the Japanese import compared to 26.36 percent for the United States, 9.88 percent for China, and 6.95 percent for Great Britain. The Swedish share of Japan's exports was even 
smaller: a mere 0.04 percent (for comparison: US 40.53 percent, China 18.31 percent, and Great Britain 2.89 percent). Assessment based on data from Ryūshi Honma, ed. Nippon keizai tōkeishū 1868-1945 [Japanese economic statistics, 1868-1945] (Tokyo: Nichigai Associates, 1999), 35-47.

37 Edström, "Japan as a Distant Friend," 230.

38 Envoy O. Ewerlöf, Report, September 14, 1923 (UDA, 2210.03.1, HP1, Xj, IV). The Kantō earthquake on September 1, 1923, wrought enormous havoc on Tokyo and Yokohama.

39 The fever was serious, but the attack turned out to be merely rumors after a servant accidentally dropped a knife, see Ewerlöf, Report, November 30, 1926 (UDA, 2210.03.1, HPl, Xk, V). For reports in the Swedish press, see, e.g., StD September 3, 19, ST September 13, October 5, DN September 14, and 21, AB September 17, Nya Dagligt Allehanda (NDA), September 18. Sweden is described as "our co-partner in humanitarian services of unselfishness" and praised the country for its policy in regard to the League of Nations in The International Gleanings from Japan, August-September 1926, a journal published by the Japanese League of Nations Association.

40 For documents and reports concerning the visit, see the Gaimushō Archives, Early Shōwa period (S), File L.1.3.0.1-9.

41 Olof Traung, Dan Broström: 1870-1/2-1920: Några kapitel sjöfartshistoria utgiona med anledning av 50-årsdagen [Dan Broström 1870, February 1, 1920: A few chapters of naval history, published on the occasion of his 50th birthday] (Gothenburg: Nautics, 1920), 33-35; Archives of the Tariff and Treaty Committee of 1919, Vol. 120; Hioki in Chügai Shögyō Shinpō August 22, 1918; Wikstrand July 21, 1920 (UDA, 2210.03.1, HPl, Xj, II); Gunnar O. Nittzell, "Gustaf Oskar Wallenberg-En bortglömd Japanvisionär” [Gustaf Oskar Wallenberg-A forgotten Japan visionary] Orientaliska Studier no. 55/56 (1994), 64-65.

42 Bergström, April 11, 1919 (UDA, 2210.02, 21, U 1, III)

43 G. Jacobson, "David Kristian Bergström," in Svenskt biografiskt lexikon [Dictionary of Swedish national biography]. (Stockholm: Riksarkivet, 1922). Online ed., 2020. https://sok.riksarkivet.se/sbl/artikel/18677

44 Bengt Hildebrand, "Ewerlöf, släkt" [The family Ewerlöf], in Svenskt biografiskt lexikon [Dictionary of Swedish national biography]. (Stockholm: Riksarkivet, 1953). Online ed., 2020. https://sok.riksarkivet.se/sbl/artikel/15574.

45 Jianlang Wang, Unequal Treaties and China (Hong Kong: Enrich Professional Publishing, 2015), 137-144. Peking was renamed "Beiping” after China's capital was moved to Nanking (Nanjing), in 1928.

46 The treaty came into force on January 1, 1929, see, ibid., 144.

47 Ingemar Ottosson, Handel under protest: Sverige och Japan på väg mot andra världskriget 1931-1939 [Trade under protest: Sweden and Japan on the way to World WarII, 1931-1939] (Lund: Sekel, 2010), 85.

48 Yngve Möller, Rickard Sandler: folkbildare, utrikesminister [Rickard Sandler: Educator, foreign minister] (Stockholm: Norstedt, 1990), 249; Erik Boheman, På vakt: Kabinettssekreterare under andra världskriget [On guard: As the state secretary for foreign affairs during World War II] (Stockholm: Norstedt, 1964), 134-135.

49 Erik Lönnroth, Den svenska utrikespolitikens historia, 1919-1939 [The history of Swedish foreign policy, 1919-1939], vol. V (Stockholm: Norstedt, 1959), 21-22.

50 Boheman, På vakt, 61; Lönnroth, Den svenska utrikespolitikens historia, 23-24.

51 Lönnroth, Den svenska utrikespolitikens historia, 10, 16-17.

52 Ibid., 13-15, 16-17. 


\section{Trade under protest A war in all but name}

At the beginning of the 1930s, the main activities that Swedes pursued in East Asia were foreign trade, Christianization, and exploration. The latter two were mostly restricted to China. ${ }^{1}$ Swedish missionaries did not endeavor to proselytize in Japan and Swedish explorers like Sten Bergman, who wrote books and articles on the Kuriles, Korea, and other peripheries of the Japanese Empire, were rare. $^{2}$ Swedish-Japanese relations were firmly rooted in commerce, especially after Japan became Sweden's largest export market outside of the West in 1931. Occasional cultural exchanges accompanied the growing commercial relationship. On November 7, 1931, for example, a large Japanese art exhibition opened in Stockholm. It was arranged by the Swedish-Japanese Association and was a remarkable success. Exhibition objects came from Swedish museums and private collectors, not least from the Royal House. Opening speeches were held by the Swedish foreign minister, Baron Fredrik Ramel, and Japanese envoy Viscount Mushakōji Kintomo. Politically, it seemed that Japan and Sweden were set for another decade of fruitful and friendly relations. Ramel and Mushakōji both stressed the hope for the exhibition to deepen mutual understanding and cordial feelings between the two peoples. ${ }^{3}$ Little did they know that Sweden and Japan were, in fact, already set for a bumpy road ahead. A few weeks earlier, a relatively minor "incident" had taken place in a remote and somewhat obscure part of China, which would eventually lead to Swedish soul-searching and to a deep crisis in bilateral relations with Japan.

\section{International politics}

\section{$A$ military action and its aftermath}

On September 18, 1931, an explosion damaged the Japanese-run South Manchurian Railway. It occurred just north of Mukden (Shenyang), the administrative center of Manchuria, in the northeastern part of China (also referred to as Dongsansheng, or "The Three Eastern Provinces" in Chinese). The TNT induced blast did not cause any injuries nor was it strong enough to seriously deform the railway tracks, but Japan's media and military immediately blamed and condemned Chinese activists. ${ }^{4}$ In reality, the "Manchurian Incident," as it 
came to be known, was a staged attack. The perpetrators were officers from the Kantō Army, which was stationed in the southern part of the Kantō Peninsula (Liaodong). ${ }^{5}$ Japan had gained the right to keep troops on the peninsula in 1905, after the Russo-Japanese War and was entitled to guard the Japaneseowned South Manchurian railway. The Kantō Army developed into a hotbed of militant extremism ever since the 1920s, becoming severely hostile to China and its nationalist movement. Its leaders were deeply disappointed with the parliamentarian and pacifist currents of the political élite in Tokyo, which, in the beginning, did not even endorse its actions during the "incident." The whole affair resembled a coup d'état, with the aim of pressuring the central government to act in China. And the strategy worked. In Tokyo the agitated press and public opinion demanded resolute retaliation against the anti-Japanese elements responsible for this "Chinese terrorist act," and the Kantō Army used the pretext to unleash a heavy military campaign over Manchuria. Abroad there were many who suspected a plot behind the railway explosion, but the conspiracy could not be proven. The government of the liberal Prime Minister Wakatsuki Reijirō soon believed it had no other choice but to accept the new situation. It feared that controversy in public would lead to a fatal loss of national prestige. A few months later the Wakatsuki cabinet resigned after strong military threats and was replaced by a leadership more sympathetic to expansion. ${ }^{6}$

On November 5, Envoy Mushakōji presented the official Japanese account of what was happening to the UD. Japanese troops, he alleged, were acting in self-defense against local "bandits" and were not carrying out a military invasion. Ramel replied that, in his opinion, an independent investigation committee would surely become necessary in order to convince the Chinese side of the Japanese viewpoint. This option was ruled out by Mushakōji, who claimed that the conflict anyway could not be understood by remote European observers. His argument that a "cultural barrier" prevented many foreigners from understanding the true character of the conflict in China was a prevalent trope of the 1930s. Surprisingly, it was also a way of reasoning that appeared even in some White Papers of the Swedish Government. ${ }^{7}$ Mushakōji might have had a hint of this "benevolent" view toward Japan's narrative. In his own report to the Gaimusho, Mushakōji emphasized that the Scandinavians were used to "standing beside" world politics as they did not often express support for countries involved in conflicts. According to him, the best way for Tokyo to deal with Scandinavia in this situation was to refrain from active propaganda in "the peaceful North."

The clash between the Chinese and Japanese in Manchuria was a turning point in the political history of the interwar years. It marked the end of a decade of relative peace, optimism, and trust at the League of Nations and the beginning of renewed global tensions and rearmament. East Asia was only the first of many regions where developments took a turn to the sinister. In January 1932, while fighting spread to Shanghai, the Kantō Army claimed that there existed a strong independence movement among the Manchu people and, on March 1, Manchurian nationalists declared that northeastern China was from now on a separate state under the name of "Manchukuo." It was obvious to most international observers that the 
new "state" was the creation of the Japanese military, but the developments happened so quickly and in complete violation of international law that within weeks the Manchu territory was de facto removed from China's control. The Kantō Army used intra-Chinese rifts to achieve this goal. In 1932 it nominated the previously dethroned emperor of China, the 23-year-old Manchu national, Pu Yi, head of Manchukuo, where he once again was elevated to the status of emperor two years later. Sincerely convinced that he was serving his people, the Manchus, the naive $\mathrm{Pu} \mathrm{Yi} \mathrm{henceforth} \mathrm{acted} \mathrm{as} \mathrm{little} \mathrm{more} \mathrm{than} \mathrm{a} \mathrm{figurehead} \mathrm{to} \mathrm{his} \mathrm{Japanese} \mathrm{masters.}$

The crisis in the East was a challenge to the League of Nations, which started an investigation. At the request of the Republic of China, it convened an extraordinary assembly. The activity was driven by a concern that the crisis also had important implications for collective security in Europe. It was a test of the League's ability to maintain international law and order. The assembly decided that a commission would be formed under a former British governor of Bengal, Lord Lytton, to carry out a much needed but time-consuming fact-finding mission. In September 1932, Japan recognized Manchukuo as a sovereign state, which led to another outcry among the international community. ${ }^{9}$ At the end of a long process, the League passed a resolution on the incident in 1933, which, on the one hand, recognized the "special position" of Japan in the region and recommended extensive autonomy under a local government with Japanese advisors, but, on the other hand, also recognized the sovereignty of China over Manchuria. The Japanese Government dismissed the result and withdrew from the League. This could have been the beginning of sanctions and other measures against Japan, but Europe had new problems due to a severe economic depression. This left China alone and Japan's belligerency unopposed.

In the end, the League was unable to solve any of the fundamental issues in East Asia, while Japan and China were both biding their time to settle accounts at a later moment. They, too, faced other problems in the short run. The Republic of China, under General Chiang Kai-shek, had to invest its energy in campaigns against a domestic enemy, the Communists, while Japan was in the midst of an internal power struggle between conservatives at the imperial court, extremists in the military forces, and party politics. Japan's parliamentarism received unexpectedly strong support from the public in the general election of 1936, which turned out in favor of moderate parties. Unfortunately, a military faction which demanded "direct imperial rule" (a convenient euphemism for a military dictatorship) reacted by staging a sanguinary coup d'état. Prime Minister Okada Keisuke only narrowly escaped the murderers while his finance minister and former prime minister, the influential Takahashi Korekiyo, who had opposed budget increases for the Army and the Navy, was assassinated in his home. ${ }^{10}$ The mutiny was eventually put down after the emperor's personal intervention. ${ }^{11}$ On the surface, the rebellious officers had lost the battle but on a deeper level, they won the power-political game. Their message was well understood; no moderate Japanese politician could ever sleep quietly again in opposition to their goals. Japan had moved inexorably closer toward a society where militarists, not democrats, had the final say. 
At the same time, in Europe, another militarist and fascist, Benito Mussolini, won a decisive victory in his own brutal war of aggression. On May 5, 1936, Addis Ababa, the capital of Abyssinia (Ethiopia), fell to Italian forces. This second breach of the Covenant of the League destroyed the last hopes for a return to the principles of law-based world order. Together with the German advance into the Rhineland and the inability of the League to prevent either event, a new balance of forces took hold in Europe. A rapprochement between anti-League powers followed, leading to the Anti-Comintern Pact of November 25, 1936, between Germany and Japan, which Italy joined the year after. It was the first step towards the alliance of the Axis Powers. ${ }^{12}$ On top of this, another crisis, the Spanish Civil War, started in summer of 1936 when, suddenly, the democratically elected socialist government in Madrid found itself fighting against royalist insurgents under the fascist leadership of General Francisco Franco. Western democracies, it seemed, were hopelessly put on the defensive.

\section{National politics}

\section{No consensus: parliament, business, and the public between idealism and realism}

In Stockholm, the first news reports about the Manchurian Incident were eclipsed by Britain's announcement to abandon the gold standard. ${ }^{13}$ It took a few months for the realization that the crisis in China would not be over soon and that Manchuria - that unfamiliar place in the Far East-would come to play a major role in world politics. In the early 1920s, almost no Swedish citizen engaged in trade or missionary activities there. A rare but prominent exception was Major Carl Taube, who lived in Mukden and served as a military advisor to warlord Zhang Zuolin, ${ }^{14}$ and published a book about the incident. ${ }^{15}$ As inconspicuous as this relatively desolate setting seemed to be, the conflict-ridden region developed unexpected importance to Swedish commerce in three fields. First, oil imports: In 1908 international traders had discovered the Manchurian soybean. Since then growing quantities of bean cakes and in particular soybean oil were shipped to Europe, among others by the Swedish East Asian Company. Soybean had turned out to be rich in vegetable fat that could be used for margarine, chocolate, soap, cosmetics, and even synthetic rubber or art silk. Furthermore, the bean was easy to store while also high in protein and since it could be consumed either directly or used as feeding stuff for cattle, it promised to alleviate Sweden from the fear of malnutrition during times of agricultural hardship. During the height of the later war in Europe, soybean was even used as a replacement for coffee beans to brew what Yuriko Onodera once observed to be the Swedish national beverage. ${ }^{16}$ Envoy J.E.E. Hultman in Tokyo once pointedly remarked that "the entire world is dependent upon the flow of oil from the Manchurian fields." 17 Second, the trading house Gadelius had understood the potential of Manchuria and opened an office in Dairen (Dalian) as early as $1921 .{ }^{18}$ During the following decade, the company carved out a niche in the South Manchurian mining sector, enriching iron ore and engaging in rock drilling. ${ }^{19}$ Lastly, also Svenska Kullagerfabriken 
(SKF), another important trading company, developed strong interests in Manchuria. In 1931, the SKF company magazine noted that the region was a promising future market for Swedish exports of ball bearings, not at least because the railways in its southern part were among the world's best. Furthermore, it was mentioned that the South Manchurian Railway already largely used ball bearings from Sweden and that one part of the machines in the big military factories at Mukden also used SKF products. ${ }^{20}$ In short, the importance of Manchuria for Swedish trade grew unexpectedly but mostly unnoticed by Swedish politicians, which turned out to produce a diplomatic dilemma after the Mukden Incident. In March 1932, when the League of Nations summoned its members to the special assembly session, Stockholm was forced to define its stance, but only little consensus existed on the two major components of the debate: Sweden's relationship with the League and its approach toward "Asian affairs."

In parliament, the strongest political force at the time was the Social Democratic Workers Party. Lacking an absolute majority, the Social Democrats were, however, not part of the government. Instead, the executive was controlled by the center-left minority government of Prime Minister Carl Gustaf Ekman (June 7, 1930-August 6, 1932), which was chiefly composed of members of the teetotaler (prohibitionist) Free-Minded National Association. On the right-wing of the parliamentary spectrum, the opposition consisted of a small Liberal and a much more influential Conservative Party, while agrarian interests were defended by the Farmers' League. There were also two proletarian parties; the Communists who strictly followed directives from Moscow, and the Socialists who claimed to be independent of foreign influence. Both "red" parties played only a marginal role since they were shunned by the much larger established popular movements. Regarding the League of Nations, all parties (except the communists) were largely divided among two schools of thought. One emphasized the need for change of Swedish foreign policy and the other stressed continuity and tradition. The former approach was broadly "idealist" or "internationalist" whereas the latter gave priority to "traditionalist" national, or at most Scandinavian, considerations that could be broadly termed "realist" in contemporary international relations parlance. ${ }^{21}$

Sweden had joined the League of Nations in 1920 after a fierce parliamentary battle in which the internationalist left had carried the vote. After that, most traditionalists turned around and accepted Swedish membership in the League. ${ }^{22}$ However, suspicions about Geneva lingered and skeptics like K.G. Westman (Farmers' League) sarcastically referred to Swedish activities at the League as "a functionalist superstructure on Swedish foreign policy." 23

The idealists interpreted the situation in Manchuria foremost as a crisis of international law and the peaceful work of the League of Nations. They put the blame for it squarely on Japan and its military. This opinion was shared by some vocal Christian and pacifist organizations. They agreed that aggression toward a faraway country had become the business of all states under the "one for all, and all for one" principle of the Covenant of the League. ${ }^{24}$ The most outspoken internationalist in this regard was Östen Undén, a law professor and former foreign minister (1924-1926) in two Social Democratic cabinets. Undén 
was arguably the foremost Swedish expert on international law, and his views on world politics were decidedly legalistic. As president of Uppsala University, he gave a public speech to his students on February 2, 1932, condemning the Japanese violence in Shanghai and accusing Japan of disturbing world peace. He demanded a firm response from the League (without, however, being specific about what measures he desired). ${ }^{25}$ Like most internationalists, Undén held the League in high esteem. In his circles, there was a general belief that Sweden and some other small states enjoyed a very high standing as particularly peace-loving and selfless members of the world organization. As the League's "watchdogs," they were believed to have a strong moral influence in Geneva to put pressure on the Great Powers. However, the supporters of the League of Nations were divided on a key issue: how to attain a desirable state of collective security? Among most (but not all) of the Swedish internationalists there was a strong resistance to armed sanctions. The anti-militarist stance led most of them to prefer an economic blockade while a small but powerful faction within the Social Democratic Party was skeptical of any government measures. They were of the even more idealistic belief that a concerted action of the world's workers would be enough to stop any war. ${ }^{26}$

More moderate left-wingers, especially the sympathizers around Arthur Engberg, influential editor-in-chief of magazine Social-Demokraten (The Social Democrat), urged a cautious line. ${ }^{27}$ After all, Sweden ought not to be dragged into war, not even "a war in the name of peace." This, in turn, fueled impatience among the most outspoken activists. An editorial in the Svenska Morgonbladet (Swedish Morning Post), the leading Christian pacifist newspaper, on February 24,1932 , demanded a resolute initiative from the small states at Geneva, including Sweden. The article caused widespread criticism and caught even international attention, as the Svenska Morgonbladet was the mouthpiece of the government party. Its statements were often regarded as the reflection of official policy. In the end, Prime Minister Ekman had to clarify that the article had been written without his knowledge. ${ }^{28}$

The right-wing opposition predictably drew rather different conclusions from the Manchurian crisis. To the representatives of the business community, stability was the condition sine qua non for trade in East Asia. In these circles, there were experts with ample information on local conditions in China. ${ }^{29}$ Their parliamentary representatives - the Liberals and Conservatives-also put less trust in collective security and were still hailing "neutrality" as their watchword. They had never given up their admiration of this supposedly old-fashioned policy and saw it as fully compatible with Sweden's membership in the League. They argued that the crisis revealed the need for greater stability in chaotic China-a view which more or less favored the Japanese stance. These "realists" also opposed the disarmament that followed the Defense Act of 1925 and wanted to rebuild Swedish military capability. To them, the events in Manchuria proved how perilous it was to put trust in security guarantees signed by the League-sheer pieces of paper without real value. They claimed that this was proof that Sweden should give more priority to its military defense. 
However, the realists, like their left-wing counterparts, were also divided. One of their controversies ranged about the nature of the League. The moderately conservative newspaper Svenska Dagbladet (Swedish Daily), for example, represented a faction that wanted to believe in the League's ideals, even if they had few illusions about the practical shortcomings of the organization. It defended Geneva against criticism from Tokyo and pointed to Japan as the aggressor. Regardless, Svenska Dagbladet did not expect Sweden to take the lead in the struggle for international order. Implicitly, it argued that one should wait for the Great Powers of Britain and France to settle the matter. ${ }^{30}$ Quite a few voices in the conservative press were inimical to the League, and some praised Japan for exposing the fraud of collective security guarantees. All agreed that Stockholm should stay in the background: this was a conflict that had nothing to do with Swedish national interest. These views flew in the face of the internationalist notion that "everything concerns everyone." 31

The only influential newspaper to give unequivocal support to Japan was Göteborgs Handels- och Sjöfartstidning (Gothenburg Trade and Shipping Gazette), a liberal newspaper close to business circles in the trading port. Its editor-in-chief, Torgny Segerstedt, often went his own way with opinions that were not always popular. Segerstedt dismissed the legalists as people to whom international order only meant respect for existing borders and the defense of status quo. International order in a deeper sense was only possible if there was justice and balance between nations, he thought. In the case of Japan, this trading power on the rise had been discriminated against by tariff barriers and by racist laws prohibiting Japanese migration. To blame were the principal Western nations, not least the United States, and they should acknowledge the need for Japan to find a way out of this desperate situation. Segerstedt was the only one to point to economic reasons behind the troubles in East Asia. He was also probably the only publicist to comment on the tension between respect for international treaties and the need for peaceful adjustment inside the Versailles system. His defense of Japan did not imply any sympathy for authoritarian government or militarism. ${ }^{32}$ In fact, during the European war years, he would become legendary as a fierce critic of Adolf Hitler and the Third Reich.

A last and obscure minority among the Swedish population were fascismleaning conservatives. They denied that the clash between Japan and China was significant at all. To them, the conflict was just an illusion created by politicians in Geneva. According to their ultra-right interpretation, both Asian nations had a basic goal in common: to surpass the West and threaten the hegemony of the white peoples. In other words, these conservatives believed in a serious menace, a genuine "yellow peril," to which only national rearmament could be a remedy. ${ }^{33}$

\section{The separate worlds of parliament and business}

In the early 1930s, the debates of the Swedish legislature normally revolved around topics like unemployment insurance, tariffs, or food prices. Speeches regarding foreign matters were rare and typically delivered by members of the 
Riksdag without government responsibility. In contrast, the Communists and the leaders of the tiny Socialist Party never missed an opportunity to castigate the League as a cabal of capitalist Great Power machinations. However, 1932 developed somewhat atypically. Already in the general political debate of January 18 and 19, the events in East Asia were commented on, and on February 26 they became the main focus of a discussion about the Swedish position in Geneva. The speakers were mostly from the parties on the left. Conservatives, Liberals, and Farmers were much less active in the debate. At any rate, the battle lines seemed to be the same as in the press. ${ }^{34} \mathrm{~A}$ particular characteristic of the discussion was that all parties frequently used the Manchurian case as a proxy in the perennial debate about Swedish defense. Thus, far from being a detached and calm exchange, the matter was tinged with strong emotions. The long-awaited disarmament conference of the League of Nations had already begun in February-timing could have been better-and the Swedish delegates would soon have to present an official standpoint on both issues-disarmament and the crisis in the Far East. Given the tacit nature of these deliberations, parliament convened behind closed doors on March 4, 1932. Under the statutes of parliament this was only possible in cases when sensitive foreign policy issues were discussed, which did not happen often-only six times during the entire interwar period. The special session regarding East Asia, from which no minutes are available, would be the shortest ever. In the end, the major parties tried to show a united front and sided with the government. ${ }^{35}$ Despite the habitual differences on foreign policy, it was customary to reach a consensus before going to Geneva.

Like editorials in the press, parliamentary speeches dealing with the growing Sino-Japanese conflict regularly centered on lofty ideals and principles, but did not often dwell on concrete sanctions. ${ }^{36}$ The Prime Minister himself tried to downplay the sanctions article in the League Covenant, Article XVI, and insisted that Sweden, first and foremost, should assist in adopting "strong, clear and resolute declarations." ${ }^{37}$ The business community, on the other hand, were proponents of a low-key Swedish posture on the Manchurian crisis. Trading houses did not want to lose foreign customers because of sudden political outbursts in Stockholm. They wanted to retain their markets and were, in fact, interested in the prospects that a new country (Manchukuo) offered. Most of the business representatives were pro-Japanese, first among them Knut Gadelius, who had moved his trading firm to Yokohama as early as in $1907 .{ }^{38}$ To be sure, Gadelius was no friend of the militarist wing in Japanese politics but he could see the conflict from the viewpoint of his host country. He thought most Swedish politicians were ignorant of the actual situation in China. Like other trade representatives, he felt annoyed by the increasingly shrill appeals from the internationalist left at home. ${ }^{39}$ To him, the idealist editorial in the Svenska Morgonbladet mentioned above was the last straw. On February 26, a group of prominent businessmen in Gothenburg sent a telegram to Prime Minister Ekman, urging the Swedish Government to show restraint in Geneva. They were supported by "their" newspaper, the Göteborgs Handels- och Sjöfartstidning. ${ }^{40}$ It was their intervention which led to Ekman's disownment of the Svenska Morgonbladet editorial. 


\section{Diplomacy}

\section{Defending national interests, but which ones?}

Naturally, the crisis became a pronounced headache to Sweden's diplomats and foreign policymakers. It started with simple challenges. For example, where could reliable information on this largely unknown part of the world be obtained from? Most "popular" information came from European or American correspondents in Shanghai or Tokyo, who were far away from the battleground, and whose reports got filtered through Western news agencies. Reliable "insider" intelligence about the mysterious explosion near Mukden reached the UD only by telegram and mail from the legations and consulates in the Far East. In some cases, the UD had to wait weeks for vital information. Judging from the government report to the Advisory Council on Foreign Affairs, the most influential information came from the Swedish Minister to Japan, J.E.E. Hultman, Ewerlöf's successor. Like most of his Western counterparts, he judged that the incident in Manchuria was symptomatic for a larger conflict inside Japan's power structures; it represented a military and chauvinist revolt against parliamentary government, internationalist diplomats, and against the conservative court circles around the emperor. Hultman interpreted the situation as the rise of a threatening part of Japan against the old elite. It was a quite accurate assessment. ${ }^{41}$

Swedish envoys in different parts of the world sent back information about the rather indifferent and passive stance of the Great Powers and the smaller colonial powers like the Netherlands. At the same time, these diplomats also revealed their suspicions toward China, often describing it as an almost anarchic country, menaced by Bolshevism. ${ }^{42}$ Like the business community, they often expressed their aversion to the "lawlessness" of China which was a constant theme in the correspondence, and which led to sympathies for Japan. ${ }^{43}$ Former envoy Ewerlöf, for instance, answered in an interview about the Manchurian question that: "my sympathies are more on the Japanese side, because Japan represents progress, order and development, something that the Chinese cannot achieve on their own." ${ }^{44}$ Government assessments were also ambivalent. While the White Paper for 1932 (printed in late autumn the year before) was strictly impartial and only contained a matter-of-fact description of events in East Asia, a previous White Paper of 1930 explicitly stated that the region did not belong to China proper. ${ }^{45}$ Another source, the "Blue Papers" (UD-issued reports on League of Nations assemblies) mentioned the conflict between Japan and China, but in cautious wording that did not accuse either party of violating the Covenant. Only vaguely did it allude to Japan's obstruction and delaying tactics in Geneva. ${ }^{46}$ At the same time, stereotypical images of Asia from the nineteenth century were also still very much present-views of an exotic continent with inhabitants who were generally "inscrutable." In this vein, the 1932 White Paper, for example, concluded that: "The ulterior motives behind the visible course of events more or less escape any spectator who is not familiar with Oriental mentality. ${ }^{47}$ In the end, Foreign Minister Baron Fredrik Ramel, who was a career diplomat, did not issue any warnings or condemnations. As late as on October 30, 1931, he declared that the 
conflict was of a complicated nature and that Sweden was not able to judge who was responsible for the latest problems in Manchuria. ${ }^{48}$

The ambivalence of internal and external assessments led to a rather timid initial response to the events in the Far East. To the UD, it was not clear what was going on in Japan or Manchuria, and it had no desire to alienate the only Great Power in the Far East. Therefore, Stockholm at first tried to balance its approach. It veiledly criticized Japan while also stopping sales of arms to China. At some level it was hoped that Sweden would not have to further deal with the Manchurian crisis at all. In autumn 1931, many believed that the incident could be solved by the members of the League Council. ${ }^{49}$ However, the longer the crisis lasted, the more reports reached the UD, and the clearer it became that Japanese aggressions-whether planned by Tokyo or just ad-hoc instigated by the Kwantung Army-were infringing on the principles of the Covenant of the League. That was an inconvenient realization because it forced Stockholm to choose between economic interests and political principles. Should Sweden engage in outspoken criticism of Japanese actions at the risk of jeopardizing its economic ties? Or should the situation be waited out without strong words of condemnation? Both options were less than ideal. On the one hand, Tokyo had become the commercial linchpin of Swedish trade strategy with the Far East and the impact of an outspoken anti-Japanese policy could not be reasonably predicted. On the other hand, something larger was at stake-the very principle of the League of Nations that no member could violate the sovereignty of another member. This was the core of the entire idealist enterprise at Geneva and a pillar of Swedish foreign policy since 1919. To use Arnold Wolfers's terminology, the situation had led to a conflict between possession goals and milieu goals. ${ }^{50}$ To the small state of Sweden, supporting international order in Asia was indirectly a way of upholding the authority of the League in Europe. At least such ideas were quite popular in the Swedish center-left government of C.G. Ekman. The choice was therefore rather obvious: Stockholm would insist on a solution acceptable to the League.

\section{The making of a foreign policy}

On February 8, 1932, with the situation in Shanghai spiraling out of control, Chinese envoy Zhu Changnian made an urgent appeal to Sweden for support at the League of Nations. ${ }^{51}$ A reply did not come immediately but Sweden was now working on a policy for the Extraordinary Assembly. The task of drafting official instructions for the government's delegates was entrusted to the ever-present idealist Östen Undén. The appointment itself was already a strong hint at what direction Sweden would take in Geneva. Undén, in fact, would lead Sweden's foreign policy while Foreign Minister Ramel stayed in the background. Undén's stance, unsurprisingly, was that the articles of the Covenant were unambiguous and universally applicable. His draft was completed in late February and was openly critical of Japan's military actions. ${ }^{52}$ While Japanese diplomats argued that justice was the right to change an inequitable situation if it threatens the nation, Undén took the view that international justice meant that violent revision of 
the existing status quo and its national borders could not be tolerated under any circumstance. ${ }^{53}$ Accepting such revisionist arguments of "might makes right" would create negative precedents, detrimental even to Sweden's security. He thus formulated Swedish policy clearly on the basis of the internal political debate and on principles of international law, and not based on the arguments of diplomatic reports from the Far East. Undén, and the Ekman government in general, listened to the rather vociferous left-wing opinions in favor of collective security. Stockholm should "speak out" on the world arena and defend the League of Nations just as it had done back in the days of Prime Minister Hjalmar Branting, who, in the early 1920s, had been a leading exponent of ardent idealism and pacifism in Geneva.

Only after the sensation created by the article in the Svenska Morgonbladet, Foreign Minister Ramel had to soften the language in Undén's draft as not to appear too anti-Japanese. ${ }^{54}$ Nevertheless, it was time for the next step. Karl Ivan Westman, the Swedish envoy to Switzerland (and brother of K.G. Westman), was entrusted with organizing multilateral support for the Swedish position by forming an entente of like-minded small states at the League-not an easy task, considering that there existed no unified "small state opinion," as was often claimed. Even the fellow Scandinavians, Denmark and Norway, were initially not in favor of a proactive policy. A meeting on February 29 finally led to an agreement on a number of basic demands. First, a ceasefire must be negotiated for Shanghai. Second, the main part of the problems related to the Manchurian dispute must be referred to mediation and arbitration. Lastly, the session of the Assembly must not be terminated, only adjourned, pending the solution of the conflict. $^{55}$

In early March, Ekman convoked the Advisory Council on Foreign Affairs to confirm there was a united front behind the official line. Secrecy was upheld and no minutes were taken, yet from the papers of the Conservative leader, Arvid Lindman, we know that the meeting was far from harmonious. Ramel underlined that the small states must not be passive but raise their voice in favor of international law. In contrast, the Conservatives and the Farmers' League declared their support of a cautious policy: Sweden should not "expose" itself. It was an unsurprising opinion, given that both parties favored emphasizing neutrality as an ideal. More astonishing was that Arthur Engberg, a leading Social Democrat, also joined them. Prime Minister Ekman, however, stated unequivocally that no case had been so clear in the history of the League. Sweden must act. ${ }^{56}$ In the end, the government had its way; the wording of the official instructions was slightly modified, and the Riksdag was summoned to a closed session. The green light was given to the foreign minister who could now address the business community and explain that Sweden must not be restrained by "short-sighted material motives." 57 A concern for collective security as a principle, rather than sympathies for either conflict party was to be Sweden's guiding interest from now on.

On February 16, the League Council made an appeal to Japan not to infringe on the territorial integrity of any member state. The Swedish delegates were 
instructed to support the appeal and to press for an immediate ceasefire in Shanghai. As usual the delegates represented different political colors: among the appointees were Rickard Sandler (Social Democrat), Eliel Löfgren (Liberal), Arvid Lindman (Conservative), and K.G. Westman (Farmers' League).$^{58}$ It was time for Sweden to make its decision public. At the request of the still invisible Minister Ramel, Löfgren (himself a former foreign minister, lawyer, and leader of the small Liberal Party) addressed the League on March 5:

(...) until the last few days the position in the Far East has become worse, and although the news appears to be contradictory, no one can deny that what is taking place is war in everything but name. At this moment I will say nothing as to what has been done by the organs of the League to put an end to this deplorable conflict. (...) No one can deny, especially after the report by the Committee of the League at Shanghai dated February 3rd, that the military means employed in the conflict between China and Japan are not in conformity with existing treaties.

Sweden, for her part, has maintained on several occasions during the League discussions that the provisions of the Covenant prohibiting the use of armed force retain their entire validity whether either of the Parties describes the use of armed force as war or not. (...), in the opinion of the Swedish Government, the landing of troops and their use in military operations on the territory of another power are contrary to the provisions of the Covenant and of the Pact of Paris. Any such attempt to extend the conception of legitimate defense in the manner adopted in the present case would render it impossible to maintain any legal international order.

(...) I realise the complicated nature of the conflict and the special conditions prevailing in the Far East. These special circumstances cannot, however, be invoked by one of the Parties as an excuse for evading the procedure of conciliation and arbitration laid down in the Covenant. ${ }^{59}$

Löfgren's speech, although it appears rational and calm for today's standards, was radical for its time and it was radical for the League. Especially the choice of words, in the original French, to castigate Japanese actions as a crisis that was a guerre en tout, sauf le nom - a war in all but name-was the strongest possible condemnation, and exactly the wording that the Chinese side urged the League to take. It elevated the "incident" to the level of warfare, which was something that Tokyo explicitly wanted to avoid because that could be used to trigger Articles XV and XVI of the Covenant, sanctions, expulsion, and even military intervention.

No other speaker that day condemned Japanese actions as adamantly as Löfgren. But that did not mean that Sweden stood alone. Other small states also intervened on the side of China, especially the representatives of Spain, Czechoslovakia, and Switzerland. Other countries took a much more evasive stance. Finland, for example, usually a convinced supporter of collective security, 
did not follow the Swedish position, mainly due to its pro-Japanese inclination that stemmed from the Russo-Japanese War when Tokyo encouraged Finnish independence. However, most reluctant were the League's kingpins, France and Britain. The British Foreign Secretary, John Simon, openly tried to appease Tokyo, claiming that it would perhaps not be possible to apply the Covenant to this conflict. ${ }^{60}$ Representing Japan's former ally during World War I, Simon wanted to solve the crisis on the basis of political expediency, not legal principles. In spite of rumors of British pressure on Löfgren, Sweden, together with Switzerland, did not refrain from siding with what was actually the Chinese standpoint. They put forward a draft resolution that called for negotiations between the parties but also demanded the withdrawal of Japanese troops from Shanghai-an inacceptable proposal to Tokyo. In the end, the Assembly adopted a more diplomatic solution. Stockholm could still claim a victory though, as the new text established that the Covenant was fully applicable to the conflict, and that members were urged not to recognize any change to the 1931 status quo, much to the chagrin of Japan. ${ }^{61}$ Before the Assembly adjourned, Sweden was elected to a 19-member committee that was given the mandate for a report on the conflict, thereby becoming a party to the fact-finding Lytton Commission. ${ }^{62}$

\section{On the world stage: the "bite" of the small states}

Japan's reaction to the criticism was furious. ${ }^{63}$ It became known as the "smallstate-side" (shōkokugawa), which was Japan's lumping together of the small countries as a single actor, which it accused of sterile formalism and total ignorance of conditions in Asia. Some Japanese media and politicians called them "hardliners" or "theory faction" (rironha). ${ }^{64}$ Interestingly, this collective blaming of small states by the Japanese press prevented Sweden from being singled out for its relatively intensive critique. Nevertheless, after the Assembly, an armed guard had to be stationed occasionally in front of the Swedish legation in Tokyo. ${ }^{65}$ As for the Chinese side, Sweden would receive declarations of gratitude from personalities like Wang Xiaolai, chairman of the Shanghai Chamber of Commerce and organizer of the nationwide anti-Japanese trade boycott. Incidentally, this boycott would benefit Swedish exporters who met with less competition in China. ${ }^{66}$ After the end of hostilities in March 1932, Sweden also resumed its arms exports to Chiang Kai-shek. ${ }^{67}$ The decision provoked no Japanese protest but certainly did not improve bilateral relations. Still, Stockholm wanted to be seen as impartial and aloof from both conflicting parties.

During the rest of the year, the world's capitals were forced to wait for the Lytton Report. At home, the national clash of opinions continued. The most fervent defender of the League was Östen Undén, who continued to give speeches around Sweden in defense of internationalism. ${ }^{68}$ More significantly, Sweden got a new government after the election victory of the Social Democrats, in September. Per Albin Hansson formed a cabinet with Rickard Sandler as his foreign minister. Unlike Baron Fredrik Ramel, Sandler was an active politician with a respected position in his party. ${ }^{69}$ With him, Swedish 
activism in Geneva would continue unabated once the much-awaited report was published.

In autumn the Council met again. On December 6, the Extraordinary Assembly reopened and Sandler immediately threw the influence of the new government behind the Lytton Report which did not recognize the independence of Manchukuo. During fresh deliberations among the small states, Sweden was even prepared to consider Article XVI of the Covenant, the sanctions article, that had until then never been used. Here Stockholm met resistance from the Netherlands and this time also from Switzerland. However, the Swedes were supported by Spain and Czechoslovakia, represented by Salvador Madariaga and Eduard Beneš, respectively. ${ }^{70}$ For Sweden, it was Undén who, in no uncertain terms, declared that world peace was one and indivisible. Unilateral military actions, including in the Far East, had to be penalized. The League must take measures, he stated, to maintain the respect for international law. ${ }^{71}$ To Undén, Sweden's first line of defense ran through Geneva.

After the long debate, Sweden, Spain, Czechoslovakia, and Ireland drafted a resolution. It condemned the Japanese military occupation and strongly recommended a non-recognition policy for the artificial state of Manchukuo. At this juncture, the Secretary General of the League, Sir Eric Drummond, intervened and demanded that the draft be revoked. He, too, preferred to appease Japan because he feared that too strong a condemnation might lead to Japan withdrawing from the League. Although the draft was not rescinded, it lost in the final vote on December 9 to a more restrained resolution that referred the matter to the Lytton Report and to the 19-member committee, thus causing further delay. ${ }^{72}$ Japanese media celebrated this preliminary outcome as a victory of Japan's chief diplomat, Matsuoka Yōsuke, over the shortsightedness of the small states. By that time, the term "small states" had already become a derogatory expression in Japan and its members were repeatedly depicted in demeaning manner. For instance, the cartoon shown in Picture 1 was printed on December 10, in the Yomiuri Shimbun, one of the country's most widely read newspapers. It accompanied a long article about the procedures in Geneva and shows Matsuoka throwing around a small state representative (bearing resemblance to Östen Undén) who had dared to "bite" Japan with the first resolution text.

However, the victory was short lived. As the 19-member committee adjourned for a Christmas and New Year's recess, Sandler and Undén were contacted by Japanese representatives who wanted to make a last-ditch attempt at convincing Sweden of the righteousness of the Japanese viewpoint. Foreseeing tense meetings, Stockholm's top diplomats decided to follow a rhetoric strategy of "fractioning" the conflict into two issues: one concerning the relations between Sweden and countries in the Far East, another the dispute between the League of Nations and Japan. In the former, they would argue that Sweden was impartial and wanted to keep the same correct relationship with Japan as with China. In the latter, though, Sweden as a loyal member of the League had to fully stand behind the Covenant. ${ }^{73}$ It was a shrewd but pragmatic way of demonstrating both neutrality and solidarity. ${ }^{74}$ 

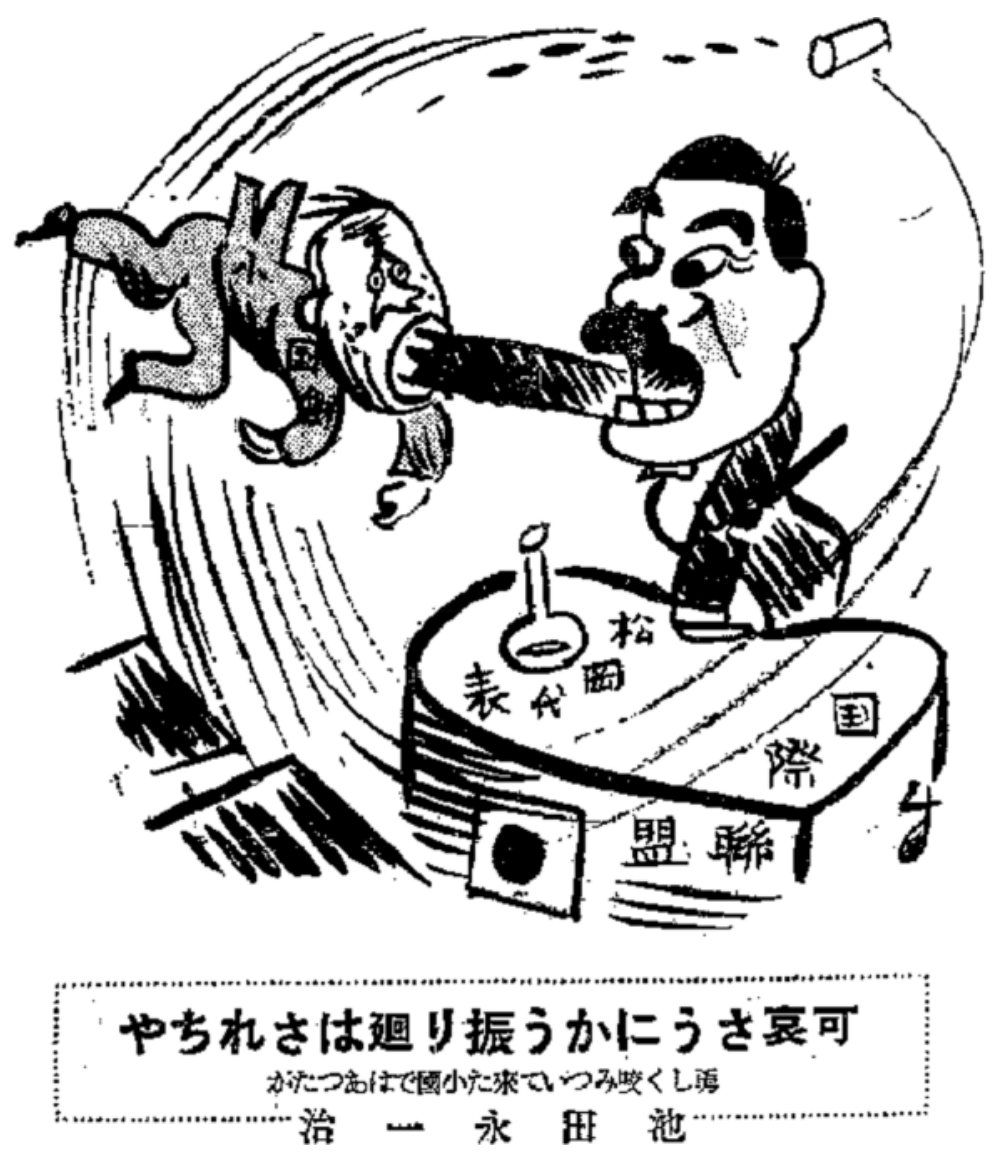

Picture 3.1 Matsuoka Yōsuke throws around a representative of the small states. Source: Untitled Cartoon by Ikeda Eiji, Yomiuri Shimbun, December 10, 1932. Note: The caption reads: "Poor guy being thrown around; Although a small country, it had the nerve to bite."

Japan, too, made use of its diplomatic talent to the fullest. In Stockholm, Ambassador Mushakōji met twice with Foreign Minister Sandler on December 13 and again on January 10. In the meantime, on December 18, Matsuoka eloquently tried to persuade Undén in Geneva to change his stance. However, both initiatives failed. Even when Matsuoka hinted that Japan might quit the League, which would endanger Undén's much-cherished world peace project, the Swede would not agree to soften his rhetoric. ${ }^{75}$ Mushakōji, too, was so frustrated about his talks with Sandler that he summarized them (not very diplomatically) as an encounter between a pragmatist (himself) with a sense of reality and a stickler of formalities. ${ }^{76}$

As late as February 1, 1933, there was still no consensus in the 19-member committee concerning how to solve the impasse. Sweden and other "radicals" 
proposed an embargo on the sales of arms to Japan, and there was also a proposal to recall all foreign diplomats from Tokyo. Although the Great Powers were still vacillating, ${ }^{77}$ the turning point was near. After another Japanese military action had taken place in early 1933, this time in Rehe, south of Mukden, a line was crossed also for London. Within days the British representative did an about-face, signaling his support for the Lytton recommendations. The committee could finally present a Japan-critical report which was officially adopted by the League at an Assembly vote on February 24-despite the fierce criticism from Matsuoka. The result of the vote was 42 to 1 . The Japanese delegation left the auditorium and, one month later, the League. ${ }^{78}$ One and a half years of peace efforts were over. In the weeks following the denouement at Geneva, the British Government implemented a provisional arms embargo against Japan and China. A British proposal for Sweden to join the embargo against both states was quickly rejected by Undén who declared that an embargo must only affect the aggressor. ${ }^{79}$ Swedish arms exports to China could henceforth be defended as an act of collective security. London soon lifted its embargos, but to the displeasure of the idealists in the League, and to the utter disappointment of China, no new sanctions were taken against Japan. The Tenno's Empire had lost face in international diplomacy, but it won the Great Power game. Manchukuo, Japan's first satellite state, was now a fait accompli.

\section{Bilateral diplomacy after the fallout}

After the vote on the Lytton Report and Tokyo's withdrawal from the League, the internationalists maintained their confidence for a while. Many predicted the imminent economic collapse of Japan due to the rising military expenditures. ${ }^{80}$ On the conservative side, the foes of the League did not hesitate in reminding the public of what they had been saying all along: Geneva helps those who help themselves. Full of irony and sarcasm, the Nya Dagligt Allehanda wrote that it was a great relief to know there existed a League of Nations since it would adopt a well-formulated resolution each time Sweden's independence came under threat. ${ }^{81}$ Parliamentary debates early in 1933 were less polemic, but only because most members of the big parties stayed away from the podium. Most active were the ultra-leftists who scornfully claimed that the League and Japan were in collusion. Despite the disappointment, parliament voted against a Swedish secession from the League-based on the rationale that withdrawal would only encourage Japan and other states with revisionist programs. ${ }^{82}$

In 1935, a report of the Swedish Defense Committee was announced after five years of inquiries and deliberations. The committee consisted of representatives from all the major political parties but the chapter on Sweden's international environment had been penned by diplomat Erik Boheman. He concluded that the League of Nations had failed in Manchuria as well as in the Latin American Chaco War. As one of the risks to world peace, he named the continued Japanese military expansion in the East. ${ }^{83}$ There were no new Swedish appeals for League sanctions against Japan. The failure of the economic blockade of Italy in 1936 
killed the last hopes that such measures would ever be taken. The situation deteriorated further in December that year, when Japan somewhat surprisingly joined Germany in the Anti-Comintern Pact. The mood in the internationalist press was by now utterly pessimistic. Among the Conservatives only rabidly anti-League newspapers hailed the agreement as a useful act of defense against Bolshevism. ${ }^{84}$ Also from the Japanese side, the mid-1930s was a moment of increased interest in the Baltic region as a front in the struggle against world communism. In 1935, Onodera Makoto, a military attaché who would play a not unimportant role during the last years of the war in Sweden, was first posted in the Latvian capital of Riga, while in 1936 a new Japanese legation was established in Helsinki. ${ }^{85}$

Occasionally Japan was mentioned by Foreign Minister Sandler in his speeches. Sometimes he talked about it in an optimistic way, like in 1934, when he expressed hope for a Japanese return to the League of Nations. At other times he referred to it pessimistically, as in May 1935, when he warned that tensions in East Asia could trigger another World War. Generally, he was critical of Japanese rearmament and he accused its diplomacy of encouraging Germany to steer an adventurous course. ${ }^{86}$ Generally, Sweden refrained from taking any new initiatives related to Manchuria. In a way it had abdicated from its responsibility and referred its foreign policy to Geneva. But this passive attitude also meant that Sweden would not try to upset the "frozen" status quo. In reply to a démarche from Belgium about Western interests in Manchukuo, that implicitly argued for the recognition of the puppet state, the UD answered that Sweden could not pursue a foreign policy on its own, but that it had to follow the recommendations of the League. ${ }^{87}$

In 1933, Mushakōji was appointed ambassador to Turkey, and already in the following year reposted to Berlin. In Stockholm he was succeeded by a man of a very different temperament, the ultranationalist Shiratori Toshio. He was already famous for his Gaimushō press conferences when he was sent to Sweden-an assignment he took as a demotion. Although a diplomat, he was close to Japanese army circles, and his statements often were undiplomatic. The decision makers in Tokyo probably saw several advantages with his appointment: they would get rid of a troublemaker and at the same time have a vociferous propagandist for Japan as their spokesman in Stockholm. ${ }^{88}$ Shiratori was quick to publish an article in the 1934 yearbook of the Swedish-Japanese Association. In the opinion piece, titled "The Reawakening of Japan," the envoy described how public opinion in his country was rallying around the emperor, abandoning the parties in parliament, and giving its support to a strong foreign policy. An era of soulless imitation and Westernization was over, he wrote. ${ }^{89}$ Time would not be very kind to his article, as Japanese public opinion did not disavow political parties and parliamentarism even during the War in the Pacific when, in 1942, parliamentary elections surprisingly strengthened many anti-militarist candidates-despite the strong government push for a one-party state..$^{90}$ In any case, Shiratori's article was the first of its kind in the usually apolitical yearbooks, which were filled with contributions dealing with Japanese art and culture. Shiratori's concern was world politics and he was firmly resolved not to spend his time in Sweden with petty negotiations 
over porcelain tariffs. He followed developments in the Soviet Union and traveled to Berlin to take part in conversations that might have been the prelude to the Anti-Comintern Pact. Already in 1936, he was recalled and would soon become Japan's ambassador to Italy. ${ }^{91}$

\section{Trade}

\section{Weathering the storm with business as usual}

The diplomatic quarrel in Geneva was a long and exhausting affair. By the time the League closed the case on Japan, without deciding to implement any sanctions, the international community at large, and Sweden in particular, had to move on with mixed feelings. It had gained nothing but a symbolic moral victory at the League-but at what price? Would the disenchantment of Japan over Sweden's role as a "ringleader" of the small states in Geneva have repercussions on its cultural exchange and the much more important trade relationship? Interestingly, the answer is a straightforward no. Despite what took place at Geneva, the commercial relationship remained stable. In the early 1930s, Swedish spokesmen would repeatedly stress the fact that their country did not have any "special interests" in the Far East. There were no Swedish colonies, no spheres of influence, and no military bases in the region. Yet, in several respects Sweden had interests in East Asia-not just in Japan but also in China. For instance, Sweden had been one of the countries that guaranteed the territorial integrity of the Chinese republic and "the open-door policy." This was because Sweden had ratified the Nine-Power Treaty, concluded in Washington in 1922.92 Swedish citizens (like Japanese and other nationals of colonial powers) still enjoyed extraterritoriality in China, and Sweden was thus a member of the cartel of foreign nations that guarded their privileges in treaty ports like Canton and Tientsin (Tianjin). Most of the Swedish business community in China was stationed in Shanghai where Sweden also operated a consulate general, which, in many respects, was more important than its legation in Peking.

Although Japan had become Sweden's largest export market in the East, commerce was not overwhelmingly lively. Actually, it was modest in absolute and in relative terms. The same was true for the other side. Sweden was Japan's main market in Scandinavia, but it was rather insignificant in comparison with much larger Japanese trade partners like the United States and China, as Figure 3.1 shows evidently.

The trade balance in the 1930s remained unchanged from the previous decades. Sweden exported more to Japan than it imported, creating a trade surplus, but at relatively low levels. Exports accounted for no more than 1 percent of the total national export value. Trade had diminished during the previous decade and fell further after the Great Depression of 1929. Only in the early 1930s imports from Japan started picking up again - albeit from a low level. ${ }^{93}$ Commerce with the Empire was not more than a footnote to Swedish foreign trade in 1931. Still, commercial circles in Stockholm and Gothenburg harbored high hopes for trade 


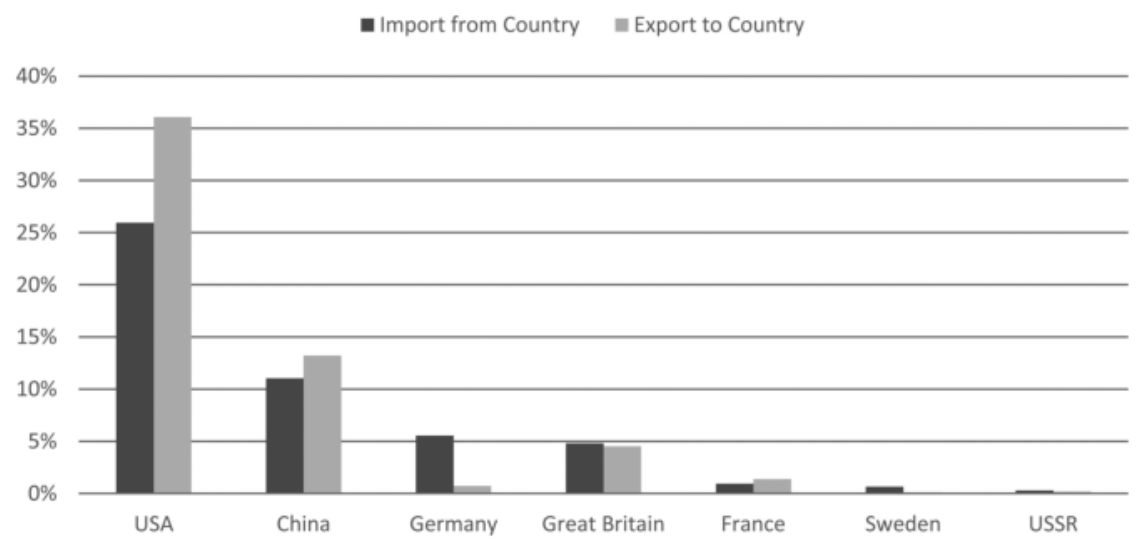

Figure 3.1 Japanese imports and exports for selected countries in 1931. Source: Data from Honma, Nippon keizai tōkeishū 1868-1945, 35-47.

with East Asia: Japan's industry was developing swiftly, and the large Chinese and Japanese populations represented a great number of potential consumers. Business analysts concluded that living standards in East Asia would rise. ${ }^{94}$ Reality would later surpass their boldest expectations. The Japan of the 1930s acted as a "hungry" nation, a challenger of the developed Western world with its high production costs. It was evident that the Japanese economy had experienced a swift recovery from the depression and entered a phase of dynamic change. Europe was now being inundated by cheap import goods "made in Japan," not least textiles, rubber boots, and toys. Japan was also in the midst of a structural transformation: factors such as the military's expansionist program and the global arms race spurred the development of an up-to-date heavy industry. This transformation also stimulated strong demand for advanced technology from abroad and there was an upsurge in the imports of modern machinery from different Western countries. This notwithstanding, European and American popular opinion railed against the "economic yellow peril." It could even be said that peaceful commercial competition evoked more hostile sentiments in the West than any military measure that Japan had ever taken during the Manchurian crisis. The Japanese economic offensive did not violate principles of international law, but it threatened domestic jobs. ${ }^{95}$

The practical aspects of commerce with the Far East were largely conducted by trading houses which acted as intermediaries. Their expertise and local knowledge were in high demand among export firms unfamiliar with the culturally different Asian markets. The three biggest Swedish trading houses in Japan were Gadelius, J.A. Kjellberg \& Sons, and Carl Ekman \& Co. An exception was Svenska Kullagerfabriken (SKF), which very successfully sold its own products directly in East Asia. The high quality of its ball bearings created a steady demand especially 
from the growingly industrialized economy of Japan. Other typical Swedish export commodities included iron, steel, paper, pulp, and all sorts of machines (turbines, pumps, drills, etc.). The sophisticated products were most sought after in the high-end manufacturing sector of the Empire where either local quality could not meet the needed standards or where technological know-how had not yet been achieved for indigenous production. On the import side, Sweden mainly bought tea, soybeans, and other "colonial goods" from East Asia. ${ }^{96}$ With only a few exceptions (like soybeans and tea), those were rarities, not intended for the mass market. The manufacturing sectors in China and Japan were not yet big enough, nor were shipping costs low enough, to create a noteworthy intercontinental export industry. That would only arise in the second half of the century. In the 1930s, East Asia was still a net-importer from Sweden. That is why the trade surplus with Japan was roughly threefold while the situation with China was even more pronounced; in 1934 exports were 14 times more valuable than imports. ${ }^{97}$ Most of these products were transported by specialized shipping companies, of which the Svenska Ostastiatiska Kompaniet (Swedish East Asian Company) was particularly important to Sweden. It was founded in Gothenburg in 1907 and, after two decades of growth, disposed of a fleet of nine modern motor vessels and seven steamers, operating routes to India and Southeast Asia, but it also sailed to Hongkong, Shanghai, and Yokohama three times a month, in cooperation with a Danish and a Norwegian firm. Its main competitor was the Japanese freight company Nihon Yūsen K.K. (NYK). ${ }^{98}$

A particularly "thorny" trade category-especially in view of the ongoing crisis in Geneva-was Sweden's role as an arms dealer. In a parliamentary speech of 1933, Communist MP Hilding Hagberg suspected that Sweden was among the nations that exported arms to Japan. ${ }^{99} \mathrm{He}$ was wrong. Swedish arms were sold to China. This had nothing to do with the Manchurian crisis. The arms manufacturer AB Bofors had been present in Northeast Asia ever since 1916, when it helped local dictator Chang Tso-lin (Zhang Zuolin) to build up a weapon arsenal. For a while, his factory was the biggest in China. ${ }^{100}$ Swedish arms were sold to competing warlords but by the end of the 1920s, the Nationalist Party under Chiang Kai-shek had unified the country. The Swedish authorities then recommended Bofors and a gunpowder exporter, AB Nobelkrut, to maintain contact only with the Chinese central government. ${ }^{101}$ According to League of Nations statistics, Sweden was the world's fifth-largest arms dealer in 1930 after Great Britain, France, the United States, and Czechoslovakia. Japan, on the other hand, was largely self-sufficient in arms and ammunition and there was, consequently, no demand for Bofors' products. SKF and the trading houses, on the other hand, sold ball bearings to the Japanese, which could be used for civilian purposes but also for tanks, cannons, and weapon-manufacturing. Ball bearings were thus partly a commodity that contributed to Japan's war industry. ${ }^{102}$

The sales of arms had always been controversial in Swedish domestic politics. Not only the communists condemned it, but it was also criticized by Christian pacifists and left-wing socialists. Together, the left accused the government of supporting Generalissimo Chiang who was described as the butcher of Chinese 
workers. This criticism diminished after the Japanese invasion of Manchuria, and Tokyo's rapprochement to the rightist dictatorships of Europe silenced it altogether. ${ }^{103}$ From the conservative side, the morally dubious trade was defended with the argument that the defense industry in a small country like Sweden had to produce for a larger market in order to be viable. ${ }^{104}$

\section{Post-crisis: the show must go on}

The years 1933-1937 were a lull before the next storm in Swedish-Japanese relations. There were tendencies toward a détente but the unresolved conflict in Manchuria continuously cast a shadow over bilateral contacts. Japan became a new topic in the national debate, framed as a potential economic menace to Swedish industry. The argument gained traction that Japan was not just militarily, but also economically, aggressive. Cheap articles from the East were suddenly depicted as "invading" Western markets. Whereas the crisis in Manchuria had been regarded as a relatively distant matter, the Japanese export offensive was believed to be an immediate threat. This feeling existed in two different quarters: among entrepreneurs in sectors hit by Japanese competition, and in the workers' movement. The latter dreaded unfair competition from workers with very low wages. In the 1930s, the specter of mass unemployment was never far away. The debate was held in a highly emotional tone. Yet there were also a number of businesspeople (mostly exporters) and economists who warned of hysteria and who claimed that the threat was being wildly exaggerated. The controversy peaked in 1933-1934 and then gradually calmed down. The anti-Japanese opinion-makers fulminated against the "dumping" of cheap Japanese goods. According to their views, Japan's economic success could only be explained by unfair trade practices. Imperialist Japan needed more markets and exploited its workers who had to put up with minimum wages and poor working conditions in "sweatshops." Books with horror stories, among them Japan's Feet of Clay by Freda Utley, a Marxist living in the Soviet Union, were readily quoted. The implicit conclusion was that commodities made in Japan should be boycotted. The question of what this would do to Japanese workers was never addressed, nor was the possibility contemplated to hold talks with Japanese trade unions in the name of international solidarity. ${ }^{105}$

Swedish businessmen in Tokyo and Osaka had a completely different view of the purported "economic yellow peril." They knew only too well that Sweden ran a large trade surplus with Japan and was vulnerable to Japanese reprisals if, for example, porcelain tariffs were to be raised. Supported by Professor Bertil Ohlin, a leading economist, they claimed that the wages of "Oriental workers" had to be put into context: the living cost in Japan was very low. Workers also enjoyed a number of important fringe benefits that had to be included in order to get a realistic picture of the social situation. Anyway, Japan exported a smaller share of its production than Sweden did. Ohlin derived the country's successes not from low wages but from the depreciation of the national currency, the yen, in December 1931. Furthermore, he added that Japanese firms had invested in new technologies and raised their productivity. ${ }^{106}$ 


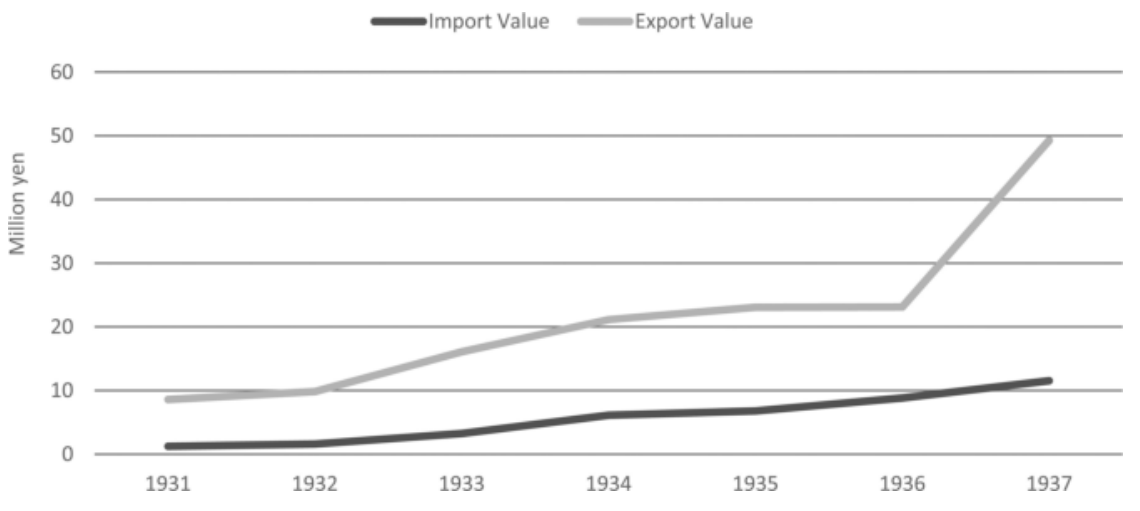

Figure 3.2 Swedish imports \& exports to Japan 1931-1937. Source: Data from Honma, Nihon keizai tōkeishū 1868-1945, 35-47. Note: In million yen.

While diplomacy and trade with Japan took place under a cloudy sky, both areas, in fact, grew again around the middle of the decade. According to Swedish trade statistics, the value of exports to Japan increased rather impressively between 1931 and 1935 from SEK 12,769,967 to SEK 21,924,432. ${ }^{107}$ Also imports more than doubled from SEK 3,615,383 to SEK 8,927,033, which, as mentioned, stirred up resistance from different interest groups inside Sweden. Figure 3.2 shows the same trend in the statistics as recorded from the Japanese side, denominated in yen. ${ }^{108}$

In the protectionist climate of the 1930s, there was ample talk in Stockholm and in Tokyo about raising tariff barriers and other methods to artificially decrease real or perceived trade deficits. For example, on January 8, 1935, Fujiwara Ginjirō, the chief executive of the large paper concern Ōji Seishi, and president of the Japanese-Swedish Society (Nichizui kyōkai), held a speech at which he pointed out that Swedes did excellent business in Japan whereas Japanese exporters met with considerable difficulties in Sweden. As a useful step to create more balanced relations and come to grips with the steadily expanding Swedish trade surplus, he suggested an official commitment from Stockholm to buy more Japanese commodities. Envoy Hultman, who was in the audience, replied at once that Sweden did nothing to deter Japanese firms from entering the Swedish market. On the contrary, he argued, there existed no trade obstacles. ${ }^{109}$ Sweden's envoy blamed a lack of Japanese interest in Sweden as an export market for the deficit. If that criticism was warranted or not is difficult to say but Swedish trading houses and export-oriented firms like SKF feared that Japanese dissatisfaction over the trade deficit might lead to retaliation against their products or that it might further alienate Sweden's friends among the Japanese. Fujiwara, for instance, was not only the president of the Japanese-Swedish Society, but also the main donor of a unique Japanese teahouse that was opened in Stockholm in October 1935. The head of SKF, Gösta Guston, therefore, wrote a private letter to assuage Fujiwara and even asked Swedish colleagues whether they could give more favorable 
treatment to Japanese goods. ${ }^{110}$ Also when the argument arose against Japanese imports that they were produced by the exploitation of cheap labor, Guston was among those who vehemently rejected the criticism pointing out the difference in living costs and the availability of social welfare programs. ${ }^{111} \mathrm{He}$ was afraid of retaliation from the Japanese side, should his country decide to implement import restrictions. He also supported the lowering of Swedish tariffs to facilitate the sales of goods from East Asia, in the hope of encouraging the Japanese parliament to follow suit and not slide further into protectionism. In the end, Guston's lobbying did not lead to significantly more imports but that would also not matter too much as trade continued. New Japanese tariffs in the mid-1930s did not hurt Swedish exports while also Sweden's upwards adjustment of import duties on porcelain (1934) was tolerated by Japanese companies as it was not exclusively directed at them. ${ }^{112}$ After all, Tokyo did not lose sight of the big picture: Sweden was one of the few remaining liberal bastions in a world of economic nationalism. Trade figures reflected that. Between 1936 and 1937, the value of Swedish exports doubled again.

\section{Manchukuo and trade realism}

Last but not least, Swedish business was also confronted with the new elephant in the room. What to do about Manchukuo? Of course, it was out of the question that the Swedish Government would recognize it as a state in any form, neither de jure nor de facto. But what did that mean for the business connection to the region? Manchukuo, with its 30 million people, could hardly be ignored as a market. After all, 15 percent of customs revenue with China had come from there. ${ }^{113}$ But even more importantly, what about the soybean oil? Manchurian soybean had been a growth market and had the potential to become strategically important for the food security of Sweden-something that its diplomats in the Japanese Empire not only recognized but emphasized very much. In early March 1937, Guston, who also served as Swedish consul in Yokohama, informed the new envoy to Japan, Widar Bagge (see Chapter 5), in two letters about the situation of soybean exports from Manchukuo. Firstly, shipments from Dairen with destination Stockholm had reached an all-time high in the previous year. A total of 136,456 tons had left the harbor. The value of that trade was SEK 20 million. ${ }^{114}$ In comparison, total imports from Japan proper for the same year were merely half that number and the total of imports from China (to which the Manchurian imports belonged in the official statistics) was SEK 28 million. Even imports from Japan proper that year were worth merely SEK 15.6 million. In terms of total trade volume, Manchukuo's soybeans accounted for roughly 1.2 percent of all Swedish imports in 1936. ${ }^{115}$ It was a commodity in high demand, as shown in Figure 3.3. Although imports from Manchukuo were certainly not a lifeline of the Swedish economy, soybean had become a not unimportant consideration to Swedish trade and diplomacy. ${ }^{116}$

Guston's detailed assessments are an interesting account in this regard. On the one hand, it is telling that he found this topic to be so important that it warranted 


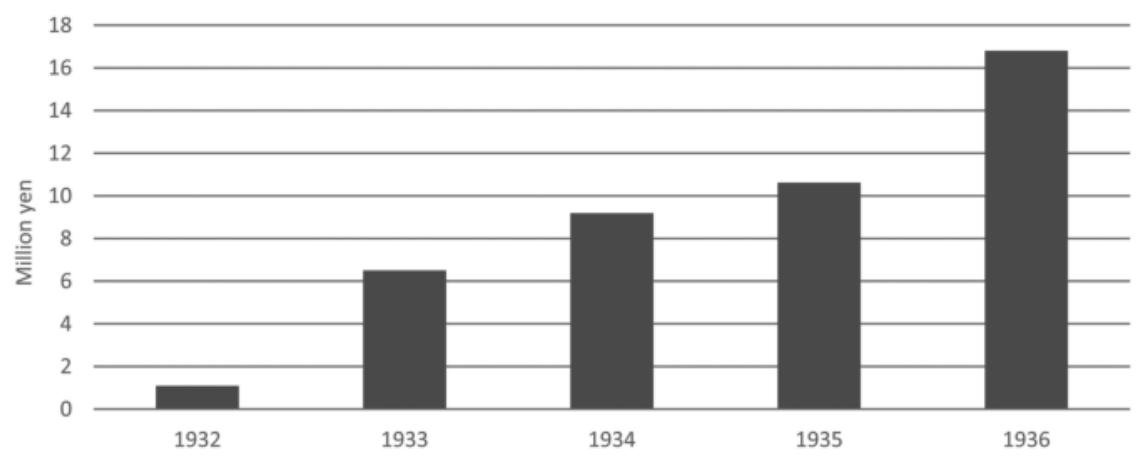

Figure 3.3 Growth of soybean imports from Manchukuo to Sweden 1932-1936. Source: Guston to Bagge, Letter, March 8, 1937 (BA, 230033.2, E4, III).

a detailed report to his new boss. Officially, Sweden recognized Manchurian soybean only as a produce of China, which is why in the trade statistics it was not included in trade with Japan. Also from the Japanese side, the commodity was not a Japanese export but one of the "independent" state of Manchukuo. However, to diplomatists no such illusions prevailed. It was clear that Swedish imports from Manchukuo depended on the good will of Tokyo to export them, and that this trade de facto was part of Sweden's commercial relationship with Japan. Guston, in fact, explicitly listed exports from Manchukuo to Sweden under the heading "trade relations between Sweden and the Japanese Empire." 117 As consul he was of the opinion that this needed to be kept in mind when negotiating with Japanese representatives. He even suggested that the recognition of this trade volume might help Sweden to receive favorable export terms with Manchukuoor at least not to be discriminated against when competing with Germany that had signed a trade agreement with Manchukuo in April 1936. ${ }^{118}$ Under such unofficial considerations for the size of the Japanese Empire, trade balance tipped in favor for it. Guston calculated in the same letter that, all in all, Sweden was running a trade deficit with the Japanese Empire of $¥ 2.6$ million. To him the strategic question was not if Manchukuo should be recognized or not-the political situation would not allow for such considerations-but how to utilize these figures to receive more favorable trade terms? He was convinced about "the importance of protecting our interests in this territory as a future valuable export market," 119 which could be achieved because the "Manchukuo Authorities well recognize the necessity of confining any discussion to strictly trade questions, and also that the unsatisfactory experience with the German-Manchukuo Trade Agreement may invite consideration of Sweden as a substantial buyer of soybeans-a fact hitherto not known." ${ }^{120}$ Guston never grew tired of emphasizing the importance of Manchukuo. In subsequent letters he recommended exploring possibilities for Swedish direct investments as well as collaborations with Japanese companies that were known for establishing factories or branch offices there. ${ }^{121}$ These comments 
were remarkably strong for an official representative of Sweden, but they must be understood in the context of his personality and the mission he saw himself promoting, namely the increase of trade relations with East Asia. Through his role as SKF manager, Guston was well connected within the Japanese business world and he had a sharp eye for local conditions. In this sense, he was an idealist-internationalist businessman, and not a representative of Swedish politics. International politics merely set the boundaries within which he and the Swedish business community operated. Overall, Swedish business was-like Guston-friendly toward Japan perceiving Manchukuo not as a threat to principles of international law and the life among nation-states, but as an opportunity to strengthen the national interest through commerce. ${ }^{122}$

Guston's views were an expression of a general trend in the second half of the 1930s, namely that trade and diplomacy were becoming even closer bedfellows than before. When long-time trade partners started isolating themselves behind tariff barriers and other commercial regulations, Sweden was increasingly forced to reappraise its trade policy and look for new markets. Official diplomatic channels became an ever more important instrument in this endeavor. "Our legations have been converted into business agencies," Foreign Minister Sandler once commented, admitting that the Social Democratic government stood behind this export activism. It was his view that "creating stable conditions for our export sector must be a main purpose in Swedish foreign policy." ${ }^{23}$ In relation to a country like Japan this demonstrated that there existed a real dilemma between money (full employment and higher living standards for Swedes) and morals (a foreign policy that was loyal to the principles of international law). This question would grow in importance as living standards inside and outside of Sweden continued to deteriorate. Sandler, therefore, tried to defend the vital importance of foreign trade to the national economy. In his own optimism for idealist goals his statements read as if though he almost desperately wanted to believe that trade might be another way of building confidence between nations:

It is necessary that we realize that, as long as Bolshevik, Nazi and Fascist dictatorships exist in parallel with democracy, all states must try to find a modus vivendi, solve economic problems and maintain the economic bonds that we need. We must not cut off the possibilities for peaceful co-existence with states having diverging political systems, just because we have a strong opinion on their nature. ${ }^{124}$

This statement stood in clear contrast to the prevailing viewpoint in the leftwing of his party, where many objected to trade that was not "politically correct." ${ }^{125}$ Also, the authority of the League of Nations continued to wane. The disarmament conference of 1932 had foundered on insoluble controversies between the Great Powers. In 1935, the League was facing a new showdown, this time because of Mussolini's invasion of Ethiopia. The sanctions fiasco made Sweden and other small states look for an emergency exit. They expressed strong doubts on the League's ability to create collective security and prepared for a 
return to their traditional policies. Eliel Löfgren's speech in Geneva on March 3, 1932 had been prophetic. In the summer of 1937, a disillusioned Swedish Government was slowly reconsidering the benefits of a "true" neutrality policy. World peace was threatened by an increasing number of hotspots and Geneva seemed powerless.

\section{Summary}

The violent expansion of Japan's Kantō Army into China, which resulted in the creation of the artificial state of "Manchukuo," and a bloody "war in all but name," was not only a serious challenge to the world community but the first time that Sweden and Japan found themselves at opposite ends of a diplomatic struggle that touched their core interests. In Stockholm, it took months until some form of consensus on the crisis emerged. However, once the decision to stand resolutely behind the principles of the League of Nations was taken, Sweden sent its most apt diplomats to Geneva to forcefully defend a rule-based international order and the noble ideas of collective security. For once, countries the size of Sweden and Czechoslovakia stood at the forefront of League actions against an aggressor state, but that did not meet with much enthusiasm by the Great Powers. Britain and France had colonies in the East and did not want to risk a confrontation with the Japanese Empire, which also served as a check on Chinese nationalism and the influence of the Soviet Union. But to Sweden and other states in favor of active internationalism, the situation looked different. The long-awaited disarmament conference of the League had started its sessions in early 1932 and negotiations demonstrated the vital link between disarmament and credible security guarantees. In the opinion of the Swedish Government, disarmament was the key issue of their time. If the League could not enforce collective security at this crucial moment, the dream of a peaceful world would have to wait for another generation. ${ }^{126}$ Stockholm, therefore, took the calculated risk of alienating Japan for the sake of the power of the League and, in the long run, for its own security at home. Unfortunately, this failed. Japan left the League, Manchukuo became a fait accompli, collective security was heavily discredited, and on top of that, Sweden's image in Japan deteriorated to that of a "nasty dog" that had dared to "bite" Asia's Great Power. At the same time, however, there was no spillover effect from the diplomatic into the commercial realm. Swedish business to Japan continued undisturbed. Trade grew significantly until 1937. Not even Swedish trade with Manchuria suffered. On the contrary, the very lucrative business with Manchukuo's soybeans grew manifold, benefitting not only the companies engaged in the business but Sweden in general who gained access to a food source that would become important in the nutrition-depleted years to follow. The initial fears over Japanese commercial retaliation for Sweden's political opposition to its actions in China turned out to be unfounded. Japan did not try to punish Sweden for its position on the world stage. By 1937, the backbone of Swedish-Japanese relations remained unchanged. Even under protest, the two nations kept trading. 


\section{Notes}

1 Despite its intensive efforts, the Swedish Christian mission never yielded any significant results. It would rather become a burden to the Swedish Government as missionaries frequently had to be rescued from local warlords, brigands, and hostile populations.

2 Ingemar Ottosson, Möten $i$ monsunen. Sverige och Kina genom tiderna [Encounters in the monsoon. Sweden and China through the ages] (Stockholm: Dialogos, 2019), 118-125; 68-80; Edström and Svanberg, Fjärrannära, $21-23$.

3 "Utställningen av japansk konst i Stockholm, november 1931" [The exhibition of Japanese art in Stockholm in November 1931], Svensk-Japanska Sällskapets årsskrift 1934, 53-56.

4 Manchuria was ruled by a warlord but formally belonged to the Republic of China.

5 In accordance with Chinese pronunciation, it is sometimes rendered as the Guandong Army (in older texts the "Kwantung Army").

6 For this and the following, see Andrew Gordon, A Modern History of Japan: From Tokugawa Times to the Present (Oxford: Oxford University Press, 2003), 186-192; Kazutoshi Handō, Shōwashi [The history of the Shōwa era], Part I (1926-1945) (Tokyo: Heibonsha, 2005), 59-110.

7 Memorandum, November 5, 1931 (UDA, 2210.03.1, HP 20, G, III); Mushakōji to Gaimushō, Telegram, November 7, 1931 (Gaimushō archives, Early Shōwa period (GMS/S), A.1.1.0.21-12-1-5, Vol. 4). In the end, Japan would agree to inspection by the Lytton Commission.

8 Mushakōji to Gaimushō, Telegram, November 1, 1931 (GMS/S, A.1.1.0.2112-1-5, Vol. 4).

9 For the proceedings of the League of Nations, see Ian Nish, Japan's Struggle with Internationalism: Japan, China and the League of Nations 1931-1933 (London: Routledge, 1993), 63-223.

10 Ian Nish, Japanese Foreign Policy in the Interwar Period (Westport: Praeger, 2002), 107-108.

11 Takafusa Nakamura, Shöwashi [The history of the Shōwa era], vol. I (Tokyo: Tōyō Keizai Shinpōsha, 1993), 193-202; Arima Manabu, Teikoku no shōwa [The Empire during the Shōwa era] (Tokyo: Kōdansha, 2010), 198-201.

12 Francis P. Walters, A History of the League of Nations (London: Oxford University Press, 1965), 684-698; Lönnroth, Den svenska utrikespolitikens historia, 1945.

13 Ottosson, Handel under protest, 78.

14 Ottosson, Möten i monsunen, 179-180.

15 On Zhang Zuolin, see Ottosson, Möten i monsunen, 179-180. On Carl Taube, see his book Kriget som inte var nagot krig. Som krigskorrespondent i Manchuriet 18 september 1931-1939 mars 1932 [The war that wasn't a war. As a war correspondent in Manchuria, 18 September 1931-1939 March 1932] (Stockholm: Bonnier, 1932).

16 Yuriko Onodera, An den Gestaden der Ostsee: Onodera Makoto als japanischer Heeresattaché in Riga und Stockholm: (1936-1938, 1940-1945) [On the shores of the Baltic Sea: Onodera Makoto as Japanese military attaché in Riga and Stockholm: (1936-1938, 1940-1945)], ed. Gerhard Krebs, trans. Ryōji and Mareile Onodera (Tokyo: OAG, 1999), 133.

17 Hultman, January 15, 1930 (UDA, $2210.03 .1, \mathrm{HPl}, \mathrm{Xj}, \mathrm{IX}$ ); Gustaf E.F. Boldt-Christmas, Olof Lilljequist, and Carl-G. Cederberg, eds. Ostasiat. Utgiven med anledning av AB Svenska Ostasiatiska Kompaniets femtioarsjubileum 1957 [Ostasiat. Published on the occasion of the fiftieth anniversary of the 
Swedish East Asia Co.] (Gothenburg: Svenska Ostasiatiska Kompaniet, 1957), 45-46.

18 Although Dairen was on the Chinese mainland, the entire city was under Japanese control as part of the "Kwantung (Kantō) Leased Territory" that had been ceded to Japan by Russia after the Russo-Japanese War of 1905. Almost a third of the city's population was Japanese.

19 Eric Brauns, Gadelius \& Co-50 år i Japan 1907-1957 [Gadelius \& Co.-50 years in Japan, 1907-1957], unpublished corporate history (Gadelius' Archives, ABB, Västerås, Sweden), 43-47.

20 H. Boman, "SKF i Manchuriet" [SKF in Manchuria], Sfären. Tidning för SKF-folk [The Sphere. Journal for SKF employees] 1931:1, 23-24. See also I. Tennberg, "Mandsjuriet, en ekonomisk maktfaktor i Fjärran Östern" [Manchuria, an economic powerbroker in the Far East], Svensk Export 1936, 69-70.

21 Ibid., 59-61.

22 Lönnroth, Den svenska utrikespolitikens historia, 36.

23 Parliamentary Records (PR) 1936 Första kammaren (FK), No. 36, 26.

24 Gunnar M. Hägglöf, Möte med Europa. Paris-London-Moskva-Genève-Berlin 1926-1940 [Encounter with Europe. Paris-London-Moscow-Geneva-Berlin, 1926-1940] (Stockholm: Norstedt, 1971), 93.

25 Ibid., 112-113.

26 Ibid., 59.

27 Editorial in Social-Demokraten, March 8, 1932.

28 Prime Minister Carl. G. Ekman, Official statement, 1932 (UDA, 2210.03.1, HP $20, \mathrm{G}, \mathrm{VIII})$.

29 Ottosson, Handel under protest, 92-96.

30 Editorials in Svenska Dagbladet, February 4, 17, 22, and 26, 1932.

31 Editorials in Nya Dagligt Allehanda [Daily miscellaneous news], February 1, March 9, and 11, 1932.

32 Editorial in Göteborgs Handels- och Sjöfartstidning, February 27, 1932.

33 Sveriges Försvar [Sweden's defense], "Västerlandet kan icke nu nedlägga vapnen" [The West cannot lay down its arms now], May 1932.

34 PR 1932, FK, No. 4, 18; Andra kammaren (AK), No. 6, 22.

35 Lönnroth, Den svenska utrikespolitikens historia, 18.

36 Among the Social Democrats, Arthur Engberg and others cautioned of the risk of world war and expressed their understanding of the circumspect policy of the Western Great Powers. Per Albin Hansson, the party leader, took a more optimistic view and was confident that the peace-loving nations would jointly solve the problem. He conceded that the League of Nations had been unable to prevent or halt military action in East Asia-but he added that the situation had surely become even more aggravated had the League not existed. This would become the standard way of reasoning among internationalists in the months (and years) to follow. See Engberg (PR 1932, AK No. 18, 22, No. 22, 17-18); Hansson (PR 1932 AK, No. 22, 25).

37 Ekman in PR 1932 AK, No. 18, 35.

38 Gaderiusu Kabushiki Kaisha was a reputed engineering corporation with a large network of Japanese clients; a successor of the company still exists in Tokyo today.

39 On Gadelius, see Ottosson, Handel under protest, 85-86. Gadelius's correspondence on the Manchurian crisis in the Gadelius archives, Vol. 191.02.003.

40 The telegram was signed by well-known business profiles such as K. A. Wallenberg, H. Mannheimer, C. Ekman (chief executive of an important Swedish trading firm in China and Japan), S. G. Janson, O. Wallenberg, and G. Borin (UDA, HP20, G, VII). See also Göteborgs Handels- och Sjöfartstidning, February 27, 1932. 
41 Hultman, Telegrams, September 21, 22, 23, and 25, 1931 (UDA, 2210.03.1, HP20, G, I); Report, October 5, 1931 (HP20 G, II).

42 Hultman, October 5, 1931 (UDA, 2210.03.1, HP20, G, II), Setterwall, November 15, 1931 (HP1, Xj, IX), Lagerberg, March 31, 1932 (P83, Xk, III).

43 Westman (Berne), October 19 and 26, 1931 (UDA, 2210.03.1 HP20, G, II); Ehrensvärd (Paris), November 30 (HP20, G, IV); Dardel (Brussels), November 17 (HP20, G, III); Adlercreutz (The Hague), January 29, 1932 (HP20, G, V); Hennings (Warsaw), February 9, 1932 (HP20, G, VI).

44 Ewerlöf to Hedin, Copenhagen, October 31, 1931 (Sven Hedin's Collection, vol. 328).

45 Redogörelse avgiven till Utrikesnämnden $i$ enlighet med $\int 54 R F$ [Report delivered to the Advisory Board on Foreign Affairs in accordance with $\$ 54$ of the Constitution], henceforth Redogörelse, 1932, 99-104. See also Redogörelse $1930,64$.

46 Aktstycken utgivna av Kungl Utrikesdepartementet, Nationernas Förbunds tolvte ordinarie möte $i$ Genève 7-29 September 1931 [Documents issued by the Royal UDA, The Twelfth Ordinary Assembly of the League of Nations at Geneva, September 7-29, 1931], henceforth Aktstycken 1931, 20-24.

47 Redogörelse, 1930, 61; See also Redogörelse, 1935, 44: "The nuances in the attitudes of Japanese and Chinese to each other on the one hand, and to the West on the other, are thought to be the result of psychological conditions of which a European only with difficulty can form an idea."

48 Speech at the Swedish Association for the League of Nations. See Fredrik Ramel, "Från årets förbundsförsamling i Genève" [From this year's General Assembly in Geneva], in Meddelanden rörande Nationernas förbund [Bulletins concerning the League of Nations] (Stockhom: Svenska föreningen för Nationernas förbund, 1931), 6-7.

49 Ottosson, Handel under protest, 98, 102. A French request to support the League Council with an official note to Tokyo was declined by Sweden. Memorandum, November 21, 1931 (UDA, 2210.03.1, HP20, G, II).

50 Arnold Wolfers, Discord and Collaboration: Essays on International Politics (Baltimore: Johns Hopkins University Press, 1962), 73-74.

51 Memorandum, February 1932 (UDA, 2210.03.1, HP20, G, VI).

52 Updated draft (UDA, HP20, G, VII). See also Ottosson, Handel under protest, $125-126$.

53 A similar argument was made by Torgny Segerstedt and his newspaper to defend the Japanese side, see Ottosson, Handel under protest, 126.

54 Henriksson to Otto Johansson at the Information Section of the League Secretariat, February 27, 1932 (UDA, 2210.03.1, HP20, G, VII); Ottosson, Handel under protest, 126.

55 Archives of the NF-byrain [League of Nations Bureau], B 1:1. The Bureau was part of the Swedish UDA.

56 Arvid Lindman's collection, Vol. 18 (Advisory Council on Foreign Affairs).

57 UDA, 2210.03.1, HP20, G, VII and VIII; NF-byrån, B 1:1.

58 Aktstycken, 1932, 52-54; Instruction for the Swedish representatives at the Extraordinary Assembly 1932 (NF-byrain, B l).

59 League of Nations Official Journal, Records of the Special Session of the Assembly: Convened in Virtue of Article 15 of the Covenant at the Request of the Chinese Government. Vol 1 (Geneva, 1932).

60 Envoy Zenon Westrup, Reports (UDA, 2210.03.1, HP20, G, IX).

61 Aktstycken, 1932, 56-57; Unno Yoshirō, Kokusai renmei to Nihon [The League of Nations and Japan] (Tokyo: Hara Shobō, 1972), 212.

62 Aktstycken, 1932, 56-58. 
63 The Japanese delegation described Löfgren's speech as mottomo gekiretsu naru genji [extremely strong words], Telegram 217 from Sawada, Geneva, to Gaimushö, GMS/S, A.1.1.0.21-12-1-5, Vol. 8].

64 See, for example, Tökyō Asahi Shinbun, March 5 and 6, 1932 (incl. extra issues), Japan Advertiser, March 26, and summaries in Hultman to UD, Reports, September 29, and November 22, 1932 (UDA, HP20, G, XIV, and XVI).

65 Hultman, Report, March 23, 1933 (UDA, 2210.03.1, HP20, G, XVIII).

66 Wisén (in Shanghai), December 15, 1932 (UDA, HP20, G, XVII). According to Koori Tetsujirō, Japan's acting consul general in Hongkong, the Chinese bought matches to an amount of totally $\$ 807,849$ from Sweden and $\$ 174,173$ from Japan during the period September 1931 through August 1932 (report to Foreign Minister Uchida 8.11 1932, GMS/S, E.4.5.0.13, Vol. 3).

67 Wisén (Shanghai), December 6, 1932 (UDA, 2210.03.1, HP64, Xk, III).

68 "Statsrådet Undén om folkförbundet och Japan-Kina" [Minister Undén on the League of Nations and Japan-China], Östergötlands Dagblad [Östergötland Daily], January 25, 1933. See also Algot Bengtson in the Social Democratic journal Tiden [Time] 1932, 32: "As we know there exist no neutral countries, thus also no Swedish neutrality."

69 In 1925, Sandler had even for a while succeeded Branting as Prime Minister, see Lönnroth, Den svenska utrikespolitikens historia, 23.

70 Aktstycken, 1932, 58-60; Westman (Geneva), December 5, 1932 (UDA, 2210.03.1, HP20, G, XV).

71 The text of Undén's speech, see UDA, 2210.03.1, HP20, G, XV.

72 League of Nations Official Journal. Records of the Special Session of the Assembly: Convened in Virtue of Article 15 of the Covenant at the Request of the Chinese Government, vol. 3 (Geneva, 1933); Westman to Beck-Friis, December 9, 1932 (UDA, 2210.03.1, HP20, G, XV).

73 Ottosson, Handel under protest, 161.

74 This argument was also necessary in order to satisfy the domestic conservative opinion that still hailed neutrality as an ideal.

75 Sandler's notes in UDA, 2210.03.1 HP1, S, III and HP20, G, XV; Undén's notes in HP20, G, XVI; Matsuoka's notes in GMS/S, A.1.1.0.21-12-1-4. Mushakōji also met with Undén on January 11, 1933.

76 Mushakōji to Tokyo, January 10 and 11, 1933 (GMS/S, A.1.1.0.21-12-1, Vol. 3).

77 Sandler to Undén, February 4, 1933 (UDA, 2210.03.1, HP20, G, XVII).

78 Nish, Japan's Struggle with Internationalism, 218-223; Shinohara Hatsue, Kokusai renmei: Sekai heiwa e no yume to zasetsu [League of Nations: The dream of world peace and how it was shattered] (Tokyo: Chūō Kōron Shinsha, 2010), 212-217. One country, Siam, abstained from voting.

79 Undén's notes from his conversation with Envoy Archibald Kerr, February 27, 1933 (UDA, 2210.03.1, HP20, G, XVIII).

80 See pro-League magazines such as Mellanfolkligt samarbete [International cooperation], January 1933, 1.

81 Nya Dagligt Allehanda, Editorial, February 26, 1933. The only newspaper to defend Japan outright was the Göteborgs Handels- och Sjöfartstidning. In an editorial, it concluded that "in view of the demands of life, legal clauses sometimes have to be set aside." See: Göteborgs Handels- och Sjöfartstidning, Editorial, December 7, 1932; see also its editorial, March 28, 1933.

82 Parliamentary Records 1933, AK No. 5, FK No. 14.

83 Betänkande med förslag till ordnande av Sveriges försvarsväsende, avgivet av 1930 àrs försvarskommission [Report with proposals for the organization of the Swedish defense, presented by the Defense Committee of 1930], (Stockholm, 1935), Part 1, 49-56. 
84 Editorials in Social-Demokraten, November 28; Svenska Morgonbladet, November 30; Svenska Dagbladet, November 2; Nya Dagligt Allehanda, November 26; Göteborgs Handels- och Sjöfartstidning, November 26 and December 3, 1936.

85 Nobuhiko Yoshitake, Nihonjin wa Hokuō kara nani wo mananda ka. NihonHokuo seiji kankeishi nyümon [What did the Japanese learn from Scandinavia? An introduction to the history of Japanese-Scandinavian political relations] (Tokyo: Shinhyōron, 2003), 35, 54.

86 Rickard Sandler, Ett utrikespolitiskt program [A program for foreign policy] (Stockholm: Tiden, 1934), 43, 75, 86; Rickard Sandler, Svenska utrikesärenden. Anföranden 1934-35 [Swedish foreign affairs. Speeches 1934-35] (Stockholm, 1936), 82 .

87 Belgian envoy to the UDA, September 2, 1936; Hans Beck-Friis, Head of the Political Section, to K.I. Westman, October 2, 1936 (UDA, 2210.03.1, HP12, $\mathrm{Xm})$.

88 Ottosson, Handel under protest, 234.

89 Svensk-Japanska Sällskapets årsskrift 1934, 3-7.

90 On the 1942 general election, see Edward J. Drea, The 1942 Japanese General Election: Political Mobilization in Wartime Japan (Kansas: Center For East Asian Studies at the University of Kansas, 1979).

91 Ottosson, Handel under protest, 235.

92 Sveriges överenskommelser med främmande makter [Sweden's treaties with foreign powers], 1925, 38.

93 Sveriges officiella statistik, Handel: Berättelser från Kommerskollegium, 19191932 [Official Statistics of Sweden, Trade: Reports from the National Board of Trade, 1919-1932]; Honma, Nippon keizai tökeishū 1868-1945, 35-38. According to Swedish statistics, the country imported Japanese goods with a value of KR 2,911,773 in 1931 (0.21 percent of the total imports); exports amounted to KR 14,035,791 ( 1.25 percent of the total exports).

94 See, for example, "Fjärran Östern på frammarsch" [The Far East rising], Svensk Export, 1931, 187. The article mentions that Japan has the highest consumption of electricity per capita in the world.

95 Nakamura, Shōwashi, I, 166-172; Manabu, Teikoku no Shōwa, 134-140.

96 Sveriges officiella statistik, Handel, Berättelse från Kommerskollegium, 1934, $475-478$.

97 Centralbyrån, Statistisk årsbok 1934.

98 Ankarcrona, "A Review of the Commercial Relations," 50-51.

99 Parliamentary Records 1932 AK, No. 17, 15.

100 Government license for arms export was mandatory since 1914. Thirteen years later (1927) the rules concerning the sales of weapons and war material were simplified. They made it possible for Bofors to export arms in unlimited quantities to any country listed on a table of states that Sweden officially recognized, of which China was one.

101 Memorandum concerning arms exports to China, October 4, 1929 (UDA, 2210.03.1, HP64 Xk, III). During these years, Bofors accounted for roughly 95 percent of the sales of weapons and other kinds of war materiel from Sweden, see, Stig A. Fransson, Bofors 350 àr [Bofors 350 years] (Stockholm: Probus Förlag, 1996), 130.

102 Kent Olsson, Göteborgs historia [The history of Gothenburg], vol. 3 (Stockholm: Nerenius \& Santérus, 1996), 129; Boström, Washington, to UDA, Report, February 28, 1933 (UDA, 2210.03.1, HP20, G, XVIII).

103 Svenska Morgonbladet, September 5, 1930; Social-Demokraten, August 29, 1930; Arbetaren, August 28, 1930; Ottosson, Handel under protest, 89. 
104 Birger Steckzén, Bofors: En kanonindustris historia [Bofors: The history of a cannon industry] (Stockholm: Esselte, 1946), 400-437; Fransson, Bofors 350 àr, 131. The Swedish share of the world's arms exports in 1930 amounted to 7.8 percent.

105 Ottosson, Handel under protest, 211-215.

106 Ibid., 218-222.

107 Sveriges officiella statistik, Handel, Berättelser från Kommerskollegium 1932-1935 [Official Statistics of Sweden, Trade: Reports from the National Board of Trade, 1932-1935].

108 Honma, Nippon keizai tökeishü 1868-1945, 35-47.

109 Ragnvald Bagge to Stig Sahlin, March 11, 1935 (UDA, 22 10.03.1, H6, Xj/262, III). The manuscript of Fujiwara's speech is found in the same dossier.

110 Guston to Fujiwara, Letters, January 11 (UDA, 2210.03.1, H6, Xj, III) and May 3, 1935 (H6, Xj, IV); Guston to Prytz, General Export Association of Sweden, March 5, 1935 (H6, Xj, III).

111 Ottosson, Handel under protest, 219.

112 Ibid., 227.

113 Ibid., 155-157.

114 Guston to Bagge, March 4, 1937 (BA, 230033.2, E4, III).

115 Centralbyrån, Statistisk årsbok, 1937, 160-161.

116 Ottosson, Handel under protest, 199-201.

117 Guston to Bagge, Letter, March 8, 1937 (BA, 230033.2, E4, III).

118 Gerhard L. Weinberg, Hitler's Foreign Policy 1933-1939: The Road to World War II (Enigma Books, 2010), 104.

119 Guston to Bagge, Letter, March 23, 1937 (BA, 230033.2, E4, III).

120 Ibid.

121 Guston suggests encouraging Swedish exporters to more closely collaborate with the Japanese automotive manufacturer Nissan, because that company was known to open factories in Manchukuo the next year. See Guston to Bagge, Letter, November 19, 1937 (BA, 230033.2, E4, III).

122 Ottosson, Handel under protest, 219-221.

123 Sandler, Ett utrikespolitiskt program, 6-7.

124 Sveriges socialdemokratiska ungdomsförbund [Swedish Social Democratic Youth League], 'Protokoll fört vid Sveriges socialdemokratiska ungdomsförbunds sjunde ordinarie kongress i Stockholm den 11-15 nov. 1934' [Minutes from the 7th Ordinary Congress of the Swedish Social Democratic Youth League in Stockholm, November, 11-15, 1934] (Stockholm, 1935).

125 Swedish Social Democratic Youth League, Minutes from the Seventh Ordinary Congress in Stockholm, Stockholm, 1935, 93; Ottosson, Handel under protest, 228.

126 Ottosson, Handel under protest, 130. For the Swedish political debate on disarmament, see Parliamentary Records 1932, AK No. 5, 6, and 18. At the 1932 disarmament conference, Sweden belonged to a group of nations called "The Straight Eight," see S. Shepard Jones, The Scandinavian States and the League of Nations (Princeton: Princeton University Press, 1939), 249. 


\section{Fading protest Total war in China}

\section{International politics}

\section{$A$ bridge to war}

Fifteen kilometers southwest of Peking there is an impressive stone arch bridge by the name of "Lugouqiao" or, as known in the West, the "Marco Polo Bridge." Since 1901, as a result of the colonial open-door policy and in accordance with a multilateral treaty, the Boxer Protocol, Japan had the right to station a military regiment in the surrounding area. For unknown reasons, on July 7, 1937, a handful of Japanese soldiers exchanged fire with Chinese troops. Although nobody came to harm, the "Marco Polo Bridge Incident" marked the next stage of Japanese belligerency in East Asia. Within days, General Sugiyama Hajime and the Japanese military capitalized on the incident to use force against an enemy that they had been wanting to fight for a while. Shanghai became a war zone when expeditionary forces landed on the Chinese coast as part of an invasion. In Japan, the conflict became euphemistically known as the "China Incident," because both sides avoided formal declarations of war. " That would have triggered US neutrality laws and cut them off from US arms and commodity markets. History today remembers the "incident" as the Second Sino-Japanese War, which lasted for eight years and killed more than 20 million people.

The first year of the war saw major Japanese victories on the Asian continent. Important population centers such as Peking, Tientsin (Tianjin), and Tsingtao (Qingdao) were conquered. The International Concession of Shanghai-which was a foreigner-administrated part of the city—was left untouched, but the Chinese part soon fell to the invading forces. Later, after taking Hangzhou, the Japanese marched on Nanking (Nanjing), the capital of the republic, which was defeated and occupied on December 13. The Nanking Massacre (Nanjing Massacre), the most notorious mass killing of the war, followed. ${ }^{2}$ After abandoning the indefensible Nanking, Chiang Kai-shek retreated to Chungking (Chongqing) which he made the provisional capital of the Republic. Meanwhile, Japan's invasion expanded. When Canton (Guangzhou) fell in the autumn of 1938, the military situation for Chiang became precarious on several fronts. ${ }^{3}$ For one, the foreign invasion greatly strengthened his internal enemy, the Chinese Communist Party. Little more than a political sect in the 1920s, the party took control of 


\section{Fading protest}

several strongholds in the Northwest, which effectively divided the country into three parts: a Nationalist (Guomindang) area, a Communist stronghold, and a Japanese-occupied zone. Chiang and Communist leader Mao Zedong officially cooperated under the umbrella of the Popular Front, but their rivalry continued, including armed battles. By the end of 1938, another political fraction emerged when Wang Jingwei, the Vice Chairman of Chiang's Nationalist Party, defected to French Indochina and started voicing support for a peace agreement with Japan. Tokyo took advantage of this to divide the nationalists and reached an agreement with Wang, in 1940, making him the head of a pro-Japanese government in Nanking.

China did not even try to alert the League of Nations until a month after the outbreak of hostilities. The disappointment over the Manchukuo affair was still running deep. Only on August 30, 1937, Chinese diplomats appealed for the first time to Geneva and, on September 12, they called for international action under Articles X, XI, and XVI of the Covenant. However, the League could do little but express "moral support" and promise to "investigate the possibility" of giving assistance. In October, it urged the signatories of the 1922 Nine-Power Treatyamong them Sweden-to mediate in the conflict. A conference was summoned in Brussels, but Japan declined to participate. The Empire considered the treaty a dead letter and even protested against the involvement of states "without substantial interests in East Asia."4 The conference ended without significant results. A few additional resolutions were adopted but to little avail. A year later, the Chungking Government once more appealed to Geneva when, to the surprise of many, the Assembly reacted resolutely, issuing an unequivocal call for sanctions on September 30, 1938. However, no member complied with the resolution and Japan simply severed all remaining ties with the League. ${ }^{5}$ Only in early 1939 the military situation stopped deteriorating for Chungking. The Japanese invasion came to a stalemate as various Chinese resistance movements resorted to guerrilla tactics and the sheer vastness of the Chinese geography started working in Chiang's favor. The more territory the Japanese invaded, the more difficult it became for them to secure the long supply routes and control the area. The Imperial forces had not planned for a protracted war. ${ }^{6}$

\section{National politics}

\section{Swedish foreign policy and the war in East Asia}

Since 1932 the man at the helm of the UD had been Rickard Sandler. His tenure as foreign minister lasted until 1939 with a three months' interruption only in 1936. A Social Democrat who had never belonged to the activist fringe of his party, Sandler was not known for his decisiveness. The prominent diplomat Erik Boheman once described him as "a sphinx with a sardonic smile uttering oracles," and the British Envoy, Michael Palairet, wrote that he was usually a "combination of reticence and affability." For example, in 1936, responding to the increasingly urgent question of Sweden's return to strict neutrality (see 
Chapter 5), Sandler argued that solidarity and neutrality did not exclude each other: Sweden's loyalty to the League did not mean taking sides in the controversies between Great Powers. Two years later, he warned of a scenario where the League itself would become an alliance of nations and that enthusiasts who demanded action in the name of democracy were, in fact, only contributing to a dangerous division. Sweden, he proclaimed, should stay out of any conflict as its first priority, hence also out of conflicts that included the League. ${ }^{8}$ Whatever the foreign minister's real opinion was on the future of a solidaristic foreign policy is hard to deduce and was known probably only to himself. However, what he lacked in firmness he compensated through political foresight. Already in spring 1937, Sandler warned the Advisory Council for Foreign Affairs (UN) in a report that "what sort of trouble a Japanese army commander in Northern China could stir up and the sequel of such an action cannot be predicted."

While Sandler was usually undecided, his fellow party member Östen Undén was still a strong supporter of a collective security approach. As the man who had held a central role in Swedish foreign policy in Geneva during the previous crisis, he had not given up on the role of the League in taming the Great Powers. Although he was no longer part of the Swedish Government, he was still a delegate to the diplomatic mission in Geneva, influencing Swedish diplomacy at the League. ${ }^{10}$

When warfare in China erupted, Sweden was left with few options. It could either choose to continue along the same path as it did in the Manchurian and Abyssinian crises, working through the League and pushing for resolute collective security measures, or it could choose to invoke traditional Swedish neutrality to avoid a new confrontation. Views about the military developments of the war varied. Intelligence implied that China was not as weak as before, and that the invasion would hardly be an easy task for Japan. A military attaché reported that the Chinese national unity in the face of war was a surprising development and that Japan, on the other hand, had to cope with a severe inner division between its military and civilians. ${ }^{11}$ In short, among foreign policymakers, there was no clear-cut position toward this renewed Japanese challenge.

The formal standpoint of the Swedish Government crystalized only over time and was finally made official through a report, in 1938. It put the blame for the warfare squarely at the feet of Japan, which it described as "having seized an occasion to subjugate China with armed force, when the European Great Powers and the United States were embroiled in various difficulties." 12 However, while the same report described the bombing of cities-a relatively new method of warfare-as a violation of international law, atrocities such as the Nanking massacre were not mentioned. ${ }^{13}$ In contrast, considerable space was devoted to the Japanese infringements of Western interests. Echoing the colonial views of the business community, the main concern of the UD was that the interests of "whites" in East Asia would be "supplanted" by those of the Japanese. ${ }^{14}$ In a similar vein, Sandler also once remarked in 1939, "the ancient and immeasurably vast China might devour its conquerors." If the Chinese could win the war on their own, he added apprehensively, their nation would become a Great Power, 


\section{Fading protest}

one without any debt of gratitude to Westerners. But whatever the outcome of the war, Sweden would experience the effects. ${ }^{15}$

\section{Shifting opinions}

Sweden's official policies remained largely within the bounds of international custom and were guided by its foreign policy goals. Public opinion, on the other hand, was more fluid. Even in 1937, views on Japan still varied greatly among different communities in society. However, compared to 1931, opinions this time would change quickly. It is important to keep in mind that the incidents in East Asia took place against a backdrop of dramatic international change: economic deglobalization, dictatorships on the march, rearmament, and recurring political crises in Europe. The rapid European transformation helps to explain some baffling political somersaults of Swedish opinion-makers between 1937 and 1939 . Staunch pacifists like Lindhagen stopped condemning Japanese expansionism, while strong supporters of the League of Nations, like Prime Minister Hansson, became neutralists. A pro-business editor-in-chief (Torgny Segerstedt), who had earlier tolerated the Kantō Army in Manchuria, turned into a critic of Japan, and politicians who had cautioned against the yellow peril were now rallying behind the slogan "Asia for Asians." Another illustrative example is the explorer Sven Hedin with his strong political commitment. In the interwar years, he was arguably the most well-known Swede in the world. His sympathies were complex: while being a close friend to China he still defended the "unequal treaties," while his strong allegiance to Nazi Germany also brought him closer to the Japanese standpoint. In short, in 1937 the future battle lines were still unclear. The Swedish press, for instance, did not equate the Tenno's Empire with Fascist Dictatorships of Hitler and Mussolini. The phrase "Japan and the Axis Powers" appears repeatedly until $1941 .^{16}$

Meanwhile, the optimism of internationalists was shrinking. Only few still believed that the League of Nations or multilateral cooperation would help small states. The sinister turn of developments in Europe empowered the voices that demanded a more cautious and self-reliant foreign policy, and the developments in Asia supported such calls. From July 1937, there was not a single day without reports about the new conflict between China and Japan. By August, most newspaper readers had realized that the hostilities formed part of the most serious war since 1918. In the same month, Pearl Buck's success novel The Good Earth, ${ }^{17}$ which dramatizes family life in rural China, was premiered at the cinemas in Stockholm. It generated sympathy for a China that was now again the victim of aggression. ${ }^{18}$ As in 1931, a good deal of debate ensued on the Sino-Japanese War, the League of Nations, and the endangered world peace. Journalists and opinion columnists disagreed on most accounts except for Japan's role as a driving force behind the events. The debate in 1937 was strikingly different from the one six years earlier. Only ultra-right-wingers still upheld illusions about a “benign" objective behind Japan's actions. They viewed Japan in a positive light because of its withdrawal from the League and for its avowed anti-communism. 
For example, the Nya Dagligt Allehanda, one of their mouthpieces, ran an article arguing that pacifism did not exist in East Asia and that "the Japanese policy in the Far East cannot be judged according to European standards. Their whole thinking is different." The broad mass of the Chinese population, the newspaper claimed, only wanted calm and security, which was something that Japan could provide. ${ }^{19}$ Of course, this was precisely the narrative that Japanese diplomats had been touting after the Manchurian Incident and which their government still wanted the rest of the world to believe. Interestingly, there was a dividing line between the ultraconservative faction and outright National Socialists (the Swedish Nazi party). The latter were strongly influenced by racial thought, leading them to abhor Japan. Their mouthpiece, Den Svenske Nationalsocialisten (The Swedish National Socialist), viewed the war in China in conspiratorial terms. It almost sounded like the German propaganda paper, Der Stürmer, when it interpreted the war as part of a grand plan for world conquest, designed by the Mongolian race and carried out with infinite patience over many generations. To the European whites, it was imperative that colonial rule would remain intact. If Scandinavia and Britain could rise again, after centuries of decadence, there would still be some hope the day when the "yellow peril" would strike directly at the West. ${ }^{20}$

The majority of the Swedish press certainly did not use this kind of language. The socialist papers were apprehensive. In the Göteborgs Handels- och Sjöfartstidning, Japan was sharply attacked as an imitator of Germany and especially Italy who took by force what they could not get through diplomacy. Almost from the beginning, the invasion was dubbed a "foray" and few observers believed Japan would be able to conquer all of China. Milder in its criticism was the Nya Dagligt Allehanda, which reported with a rather cool-headed attitude, typical of a newspaper framing the world in terms of Realpolitik. ${ }^{21}$ Mainstream media mostly worried that the camp of "hungry states" would unleash an aggressive war against the weak democracies which could lead to another world war. Liberal papers agreed, but Torgny Segerstedt formulated the problem in a peculiar (racist) way: if no Western power took action against Japan, it would mean the end of white world hegemony. Japan would establish control over East Asia, the largest market on earth, and the colored races would rise up also in Africa. This would mean that the British and other colonial empires would be a thing of the past—something his newspaper branded as bad news for Sweden. Göteborgs Handels- och Sjöfartstidning, the paper that previously had criticized Western colonialism, had obviously changed its mind when it came to the conclusion that British and French rule was beneficial after all. It argued that this would bring the Swedes security in a perilous world. If the West could not act from a position of strength, its business interests would not stand a chance in the East. Suddenly, racial solidarity was paramount also to this paper, as it thought that Asians might unite under Japanese leadership. On the other hand, Segerstedt's liberal newspaper also touted democracy. Moreover, the articles were eloquent and very remote from the crude style of the Nazi press. Yet, the opinions on the issue of the SinoJapanese War were remarkably similar. ${ }^{22}$ 


\section{6}

Much less discussion occurred in parliament. The worsening world situation and the unreliable mechanism of collective security had created deep disillusion among the internationalist MPs, normally the ones most eager to discuss foreign policy matters. The only exception was Carl Lindhagen, the oldest member of the Swedish parliament. Nominally, he belonged to the Social Democratic Party but his speeches on "little Japan, overpopulated and deprived of natural resources," were far off the party line. Although he was a pacifist, he also harbored strong Pan-Asianist feelings, deeply suspicious of Western colonial power. That might explain a bizarre statement when he said that Japan had "recuperated Manchuria for the Mongolian nation." ${ }^{23} \mathrm{He}$ was a left-wing outlier who chose to believe and repeat Japan's narrative of the Empire being the only Great Power in Asia which confronted Western colonialism and the "lawlessness" of China. Which, ironically, was the same narrative that the ultra-rightists propagated-albeit for very different ideological purposes. Overall, Swedish party leaders talked less and less about Asia in their public speeches. They were more preoccupied with the storm clouds over Europe. Just as many had warned, the failure of the League to solve the Manchurian crisis had also created a dangerous precedent for Europe.

\section{A boycott movement and the debate on freezing trade with Japan}

Today the Sino-Japanese War has become most infamous for atrocities like the Nanking massacre. However, while it was in progress, the Swedish press mostly focused on other topics. Much space was devoted to the war in the air. The bombing raids on big cities like Shanghai, Nanking, and Chongqing fomented a movement of furious protest all over Europe. Not much fantasy was needed to realize that the bombing of civilians could also become a reality in another general war in Europe. In fact, it was already happening in Spain, gruesomely exemplified by Franco's leveling of Guernica in the Basque Country. European protest usually came from the ranks of Socialists and Liberals, and Christian pacifists who were seized by an almost holy wrath because of their strong emotional ties to the missionaries in China. By and large, it was the same ideological spectrum that had already opposed Japanese actions and voiced protest during the Manchurian crisis. Foreign Minister Rickard Sandler was beleaguered by peace organizations that wanted him to deliver petitions, statements, and resolutions against the indiscriminate bombings of the big cities of China. On October 9, the Swedish Committee of the International Peace Campaign visited him and demanded urgent application of the League Covenant, restricting trade with Japan. Simultaneously, the Ecumenical Board of Sweden started fund-raising for war refugees and medical equipment under the name "The China Aid." Within four months, it collected SEK 170,000, which was a respectable sum. Chinese Envoy Wang Jingqi effusively praised the Swedish effort in a letter to his own government. ${ }^{24}$ Sandler himself was not completely hostile to the movement but resisted its pleas nevertheless. His conviction was that trade issues must be separated from ideological preferences-which remained Sweden's official policy. ${ }^{25}$ 
Many anti-war activists suspected that the League of Nations would remain passive again and that independent initiatives would be needed. That became the background for a consumer boycott movement against Japan. Supporters and opponents mobilized a catalogue of arguments that was inspired by similar opinions in the Anglo-Saxon world. For example, in Great Britain a mass meeting was held in Albert Hall on October 5, 1937, where representatives of the Labour Party urged consumers not to buy Japanese products, while the Archbishop of Canterbury denounced the air raids over China as barbaric acts. In the United States too, the American Federation of Labor (AFL) was organizing a trade boycott. These initiatives were underpinned by the belief that the dictatorships were in dire economic straits, and that consumer boycotts could have a far-reaching effect. The debate on trade and morals was very much alive in 1937 and 1938. The global boycott movement swiftly spread to Sweden where the Social Democrats published reports from "the financially and socially undermined Japanese Empire." They referred to Freda Utley, who was by then a leading name in the consumer movement and a fierce critic of Japan. While many in the movement mainly wanted to express their disappointment with the failure of the League's sanctions system-even accusing the League of appeasement - there also was an ideologically motivated belief in the power of ordinary people. Some wanted to resuscitate the old idea of a workers' blockade, a form of grass-root level sanctions. ${ }^{26}$ In Gothenburg, the Association of Free-minded Women adopted a manifesto urging Swedish, British, and American customers not to buy Japanese goods. On October 8, just three days after the rally in London, the Swedish Federation of Trade Unions (LO) and the board of the Social Democratic Party made statements that endorsed the appeal. It was clear to most, however, that putting the boycott into practice would be no easy feat. Without origin marking of products in the stores, how could consumers know what goods were actually Japanese? But supporters of the boycott movement rarely contemplated the practical difficulties of their demands. Japan's economy was believed to be in extremely bad shape. Thus, some activists presumed the problem would "solve itself" with just a little help from the outside. However, prospects for the movement were not good. The LO had launched a trade boycott of its own against Germany, in 1933, without official endorsement from the Social Democratic Party. This campaign had met with little success, which led some well-known internationalists, like Elin Wägner, a pioneer for women's rights, to dismiss the new boycott against Japan. Attempts to obstruct trade would hardly aid the Japanese opposition but rather bolster the forces behind militarism, she wrote. ${ }^{27}$ The population would only close ranks behind their government. Other voices deplored the lack of dialogue between Western liberals and Japanese anti-militarists, and some representatives of organized labor expressed misgivings about unemployment in Europe if a boycott escalated into trade war. ${ }^{28}$

Unsurprisingly, also Swedish exports came under scrutiny. Mauritz Enander, the editor of Informationsbyran Mellanfolkligt Samarbete för Fred (Information Bureau on the International Co-operation for Peace), indirectly accused Sweden of facilitating Japanese warfare. He reminded his readers that the Swedish goods 
most popular in Japan were products essential for waging war. Exports to this Asian Great Power certainly yielded profits but they were not all that important to the national household. Anyway, Swedish industry received and served so many orders that it could not satisfy all customers - a clear sign of Sweden's complacency with Japanese actions, in Enander's eyes. ${ }^{29}$

An interesting sideshow of this debate was a somewhat different campaign against the planned Tokyo Olympic Games of 1940. Should a country that was invading its neighbor be allowed to host the world's foremost peace event? In summer 1938, the Swedish Olympic Committee received an open letter from a number of (left-wing) youth organizations, among them some Christian and teetotaler associations. They questioned Swedish participation in activities which would obviously serve Japanese propaganda. However, before the question reached a point of a true discussion, the issue disappeared from the agenda. In July 1938, Japan relinquished its right to arrange the Olympics-probably not over Western indignation but because the costs of building an arena would have strained the national budget at a moment when nationalistic priorities were clearly with the Army and Navy. ${ }^{30}$

While the boycott movement did have some momentum, it never convinced a majority of the Swedish public. Many remained skeptical of consumer action, like Göteborgs Handels- och Sjöfartstidning, which declined to comment on the question in its editorials. Liberal papers even pointed to the utter futility of trying to isolate Japan. "The eagerness to boycott Japan died quickly in Britain. Business and most newspapers oppose the movement," declared a headline already on October 15, 1937. ${ }^{31}$ Torgny Segerstedt had called for Western action against Tokyo but, evidently, hoped for political measures that would not primarily hit trade. After all, his newspaper represented the commercial circles of Gothenburg. Right-wing newspapers such as Nya Dagligt Allehanda scorned peace activists who wanted to cure evil with something even worse. A nation at war would never sign a ceasefire just because a few foreign countries expressed their moral indignation. The paper declared that those who feared aerial bombardment in Europe had better turn to Bofors, the Swedish manufacturer of modern anti-aircraft guns. ${ }^{32}$ The paper was joined in its criticism by the chairman of the Conservatives, Gösta Bagge. He denounced the movement as engaging in "private foreign policy," which he thought was meddling in the work of diplomats and statesmen that would do more harm than good. ${ }^{33}$ Sure enough, enthusiasm for a consumer's boycott against Japan soon abated. It was eclipsed by indignation over the developments in the Spanish Civil War. The issue was raised in earnest only once more in the parliamentary sessions of spring 1938 when the Communists demanded mandatory origin marking of imported products. However, their request was rejected as a violation of existing agreements. ${ }^{34}$ In the end, the movement disappeared and there is no evidence that it had an impact on Swedish foreign trade. Soon, news about Japan's war in China died down. There were still sporadic reports about gas attacks against Chinese troops and civilians, and in autumn 1938, detailed accounts about the Nanking massacre finally surfaced in some newspapers but they did not receive much attention 
anymore. ${ }^{35}$ After a year, the initial indignation had exhausted itself and the war in the East was overshadowed by the conflicts closer to home. Chamberlain was now on his way to Munich.

\section{The corporate world and the conflict}

In stark contrast to the boycott movement, the Swedish business community not only clung to basic optimism about trade but even argued in favor of Japan. Swedish businessmen viewed Japan as a guarantor of order and stability in the East, unlike China which they often portrayed as suffering from irresponsible nationalism that was paving the way for Sovietization. ${ }^{36}$ This perception was especially common in Sweden before 1931 and the business community did not substantially revise its views even after the Mukden Incident. Most Swedish firms in China seem to have welcomed the Japanese conquest. However they had mixed feelings toward the realities of military occupation. Some observers worried that "the open-door policy" would be abolished and that the Japanese would install themselves as the new masters of the Middle Kingdom. Westerners would then see their opportunities limited step by step. We can find such views in a letter written in autumn 1938, by Sigurd Yngve Eurén. He was the executive of the American Far Eastern Match Co. in Shanghai-which was actually a subsidiary of the Swedish Match Corporation (STAB). Eurén worried about the future after the war, but he mainly blamed the Western Powers for the situation. They had encouraged the undemocratic Nanking regime and missed the chance of coming to an understanding with Japan. Eurén also believed that the Chinese in Manchuria and other places would have a better future under foreign rule than under their own government. Still, he was not confident about Swedish prospects in the country. More optimism was voiced by a representative of Ekman Foreign Agencies Ltd. who believed a Japanese victory was within reach and that this would create a unique market opportunity for foreign firms already established in China. ${ }^{37}$ Such arch-liberal ideologies strictly separated politics and business, believing that nearly all trade was apolitical in nature. They were, therefore, little concerned with the political (or moral) nature of business opportunities, even when operating in an environment shaped by belligerency.

Another example of a Swedish apologist of Japan's actions was Robert Thune at Gadelius. He claimed that the Japanese economy was in good shape (he dismissed all rumors about inflation) and that the citizens of Japan stood behind their government, which he thought had no ambitions to conquer territory on the continent. Like the far-left politician Carl Lindhagen, the business-liberal Thune also chimed into the Japanese narrative that it was just natural that a country with such a large population needed more resources. Communism and Fascism, Thune believed, were ideologies alien to Japan, and foreigners were still well-treated. ${ }^{38}$ Other leaders of Swedish businesses in Japan agreed. For instance, Gösta Guston, the representative of SKF, and Swedish honorary consul in Yokohama, published an article in 1939 in the Svensk Tidskrift (The Swedish Journal) arguing that "by managing China's natural resources and by kind treatment of the general 
populace they [the Japanese] hope to raise the standards of living to a level where the Chinese can buy Japanese articles to a desirable extent and also adopt a more conciliatory attitude to the men of 'the new order'." 39 Gösta Guston, too, reasoned in purely economic terms. He saw the invasion of China as nothing other than a way of securing an outlet for Japanese products and improving the purchasing power of Chinese customers. The towering menace, according to Guston, was Communism - in the shape of Chiang Kai-shek! The SKF representative and honorary consul, took the view of the Japanese Government that Chiang was but the scourge of the Communists. According to Guston, the Japanese planned to police China "by ultramodern motorization and strong air fleets," and he added that such occupation forces would not need to "be so numerous as to disturb." ${ }^{40}$ His first priority was business, not the civilian population. On October 5,1937 , during a meeting between leading Swedish businessmen and the new envoy to Japan, Widar Bagge, Guston expanded on his optimistic assessment, stating that he thought the war had opened opportunities to sell substantially more steel to Japan than before. Other members of the meeting were more critical-albeit not critical toward Japanese actions. Nils Ericson, the Carl Ekman \& Co representative, stated bluntly that the major obstacle to prosperous business in this market was “the unfortunate effect of Sweden's present political attitude towards Japan," by which he meant Sweden's criticism at the League of Nations. Envoy Bagge tried to ward off the accusation by saying that foreign policy was beyond the agenda of the meeting, but Ericson reiterated his point, stating that Swedish foreign policy was highly relevant because in Manchukuo the Japanese clearly favored the Germans and never the Swedes. Guston objected saying that the Japanese were buying what they needed and cared little about the country of origin. In the end, Bagge closed the awkward topic by promising that he would do anything necessary in order to assist Swedish business-nota bene in Japan and Manchukuo. ${ }^{41}$

The October meeting shows not only how Japan-friendly Swedish business in the Empire was but how diplomacy, policy, and trade started converging as the security situation in East Asia deteriorated. All in all, it was a delicate moment, considering that Sweden did not recognize Manchukuo nor any changes in China brought about by force. Envoy Bagge was caught in the middle between the position of his government and the demands of the business community. However, compared to his predecessor, J.E.E. Hultman, Bagge was clearly more inclined to cultivate a closer relationship not only with Swedish business in Japan but also to the parts of East Asia that were under Japan's de facto control. He even promised to turn to the Parliamentary Treaty Committee concerning Swedish trade with Manchukuo. He wanted to ask for a report about possible measures for establishing state control of soybean imports. He had planned to use such a document as a bargaining chip with the Gaimushō to help Swedish exporters in Manchukuo. ${ }^{42}$ But even with this far-reaching pledge, it was not easy to satisfy the impatient Swedish businessmen. In spring 1938, Bagge indignantly reported that Guston, Ericson, and Ingemar Tennberg, the Gadelius representative, had acted behind his back when they entered into direct negotiations with authorities 
in Manchukuo, especially with Director Matsushima Kan, the Japanese head of the Manchurian Agricultural Product Institute. Guston, who in his capacity as Swedish Honorary Consul visited the Kantō Leased Territory (the part of mainland China that Japan legally controlled), had promised Bagge that he would not go further than to the port city of Dairen. But, in utter disregard of that promise, he traveled to Hsinking (Xinjing/Changchun), the Manchurian capital. This act of defiance was so grave that Bagge had to write a letter to the UD to explain the incident and apologize. ${ }^{43}$ Luckily, the affair passed fairly unnoticed internationally and there is no evidence that Guston or the other businessmen were given an official reprimand. After all, Bagge and the business community were on the same side, agreeing on the goals of Swedish trade diplomacy-just not always on the means.

Another noteworthy episode occurred in spring 1938, when the financial magnate, Axel Wenner-Gren, the chairman of the board of Electrolux (a leading home appliance manufacturer), visited Tokyo. He arrived on board his luxury yacht, which attracted much media attention. For Japanese newspapers, it was a glamorous episode in the midst of wartime restrictions. Among other statements, the financier reportedly promised that a full Swedish trade delegation would be sent to Japan and Manchukuo, although he also added that he was "not directly related to this matter." He also talked openly about bartering Swedish steel and Manchurian soybeans and that he would be holding "important talks"

with Foreign Minister Hirota and Trade Minister Yoshino. Envoy Bagge was understandably annoyed as he had to vehemently correct these statements and clarify that Wenner-Gren was not a representative of the Swedish Government as he had made it seem. ${ }^{44}$ This affair, again, shows how Swedish business did not worry much about Japanese belligerency in China. The warfare hardly dampened Swedish commercial enthusiasm, at least not as long as it seemed to generate opportunities for their ventures.

\section{Diplomacy}

\section{Attempting a League response-again}

When hostilities at the Marco Polo Bridge began, the prospects for a collective security endeavor through the League of Nations were unclear. The attempt of applying sanctions against Italy (1936) had already failed miserably. Stockholm was mostly looking toward London and Paris and their willingness to commit military resources to East Asia. ${ }^{45}$ However, neither Great Power was willing to risk confrontation. ${ }^{46}$ This became the leading argument for proponents of a cautious Swedish foreign policy. That is why on September 2, 1937, when the Chinese Minister to Switzerland, Hu Shize, presented his country's version of the "incident" with a plea for support, the Swedish Envoy, Karl Ivan Westman, was unable to commit to diplomatic action. Privately, there was no doubt about the situation. In his report, Westman wrote that he had no illusions and that the confrontation in China was, in fact, a real war-despite the lack of an official declaration. 


\section{Fading protest}

This was clearly a case for the League under Article XVI of the Covenant. ${ }^{47} \mathrm{His}$ government, on the other hand, was weary about commitments. Only after the League had begun discussing the case did Stockholm deliberate internally on a course of action. Not surprisingly, its position remained vague and ambiguous.

As a compromise between those who still believed in collective security and those who did not, a consensus was finally reached, to the extent that Sweden should not hesitate in its support for a firm attitude toward Japan, but that it should act as discreetly as possible. Consequently, the instructions that Westman received from his ministry stated that the government was prepared to observe the League's rules but only "in the light of gained experience of how they have been put into practice." Westman should voice critique on Japan but should not demand any measures. Stockholm was not willing to expose itself again through a call for sanctions. ${ }^{48}$ This awkward positioning stands in strong contrast to 1932, when the Swedish consensus was that everything possible should be done to openly support the League's collective security mission. By 1937, Swedish expectations toward the League were low. ${ }^{49}$

It is worth noting that this cautious approach of the UD was not unchallenged. Internally, there were still a number of internationalist parliamentarians with rather strong anti-Japanese opinions who wanted to see a more resolute Swedish position in Geneva-most of them Social Democrats. The political left felt a strong repugnance to Tokyo's imperialism that stood for everything they detested. In addition, the fear among unionized workers of low-wage Asian competition had made Japan even more unpopular. Even the Prime Minister voiced support for a condemnation of Japan's methods of warfare. Meanwhile, on September 28, 1937, the League adopted a resolution against aerial bombardment, which saved the UD's approach as Sweden was not pushed to stand out through an initiative of its own.

On September 30, Sweden was elected to one of the subcommittees of the 23-member committee, which had been appointed by the League in 1933 to handle the conflict over Manchuria. This became another awkward affair for Swedish diplomats. "Of course we did not lift a finger to get into the subcommittee, yet we were nominated," reported Westman. The decision to accept the nomination was taken only after consulting with Östen Undén who agreed to represent Sweden in the committee. Undén had not yet given up his activism and wanted to take a resolute stance. Aware of the severity of the situation, he pushed the subcommittee to show its teeth by calling for a declaration that would state clearly that Japan had resorted to force on Chinese territory and, therefore, that it had violated the Covenant of the League. Had that proposal been accepted, Japan would have been thrown immediately back into the spotlight as a violator of Article XVI. But nobody, not even the Soviet delegate, seemed willing to go that far. The British spokesman retorted that the situation in China was complicated and it must not be forgotten that Japan had treaty rights to keep soldiers on Chinese soil. With no support from any Great Power, Undén was arguing for a lost cause. The paradigmatic positions of 1932 remained unchanged. ${ }^{50}$ The following resolution of the subcommittee, adopted in a plenary session on October 
6 , did not contain any demands for sanctions. Its only "strength" was that it did not create a compromise with the Japanese standpoint. Members were asked to refrain from action that could diminish China's ability to resist Japanese actions. ${ }^{51}$ Thus, the League could claim that at least morally it supported China, which mirrored the UD's preferences. On the other hand, the resolution also included a paragraph that stipulated further deliberations under the provisions of the NinePower Treaty of 1922, which meant that Sweden, as a signatory of the treaty, would have to appear in the limelight again - a rather unwelcome development to the prudent UD. ${ }^{52}$

\section{A conference without a compass}

During the preparations for the conference, it was once more Undén who was the most optimistic voice at the UD. He had outlined a policy proposal about the opportunities for Sweden to positively influence world affairs and refuted the negative attitudes that he had heard from the Norwegian foreign minister. ${ }^{53} \mathrm{He}$ still had faith in the idea of collective security. That was, however, a minority view. Most of his colleagues were decidedly less enthusiastic. Not even Foreign Minister Sandler thought much of the conference. Hans Beck-Friis, the head of the Political Section at the UD, even hoped the conference would make a distinction between the original signatories and countries that had acceded to the treaty afterwards-like Sweden. That way, the Swedish delegation would have been justified in taking a passive attitude on all political issues. To him, the only advantage of the conference was the chance to discuss commercial navigation in the Far East. ${ }^{54}$ In all fairness, Sweden was not alone in its lackluster attitude. Several small states had given their representatives instructions not to take initiatives. ${ }^{55}$ The signals from France and Britain were anything but positive and some commentators were already hinting at the conference becoming a second Non-Intervention Committee, which was the policy of the European states not to intervene in the Spanish Civil War. That policy ended up directly benefitting the aggressor-and later dictator-Francisco Franco. ${ }^{56}$

This time, Undén was not appointed to head the Swedish delegation to the conference. Following the Danish example, Stockholm nominated its envoy to Brussels, the career diplomat Gustaf von Dardel, to the job. He was accompanied by only one aide from his legation (the secretary C.F. Wachtmeister). In contrast, three of the Great Powers sent their foreign ministers: Anthony Eden (Britain), Yvon Delbos (France), and Maksim Litvinov (Soviet Union). ${ }^{57}$ In the case of France and Britain, they were accompanied by over a dozen high-ranking statesmen and diplomats. Even the United States sent one of its most skilled negotiators, ambassador to the League of Nations, Norman Davis, together with three more diplomats to Brussels. ${ }^{58}$ Sweden's meager contribution was thus a clear message that it was not even contemplating to take a meaningful initiative.

The conference suffered from bigger problems than Swedish disinterest. When it opened on November 3, 1937, the most important seat at the table was empty. Japan was absent. Tokyo declared that the conference was convened by 


\section{Fading protest}

the League of Nations, an organization to which it did not belong anymore and that had several times adopted resolutions that Japan deemed unfriendly. Against all expectations, Britain, France, and the United States took a firm stance. They stated that the conflict in the Far East was a relevant question for the treaty powers and for all the world. They also observed that China was showing its preparedness for discussions whereas Japan was refusing to do the same. According to their resolution draft, the treaty powers were urged to hammer out a "joint policy" against a country that did not recognize its international obligations, which was a thinly veiled threat against Japan. For once, the small states were caught off guard. Contrary to their previous behavior, this time it was they who tried to soften the language. Sweden put forward a suggestion that the word "joint" be deleted from the declaration. This did not satisfy the Norwegians who thought the declaration was too far-reaching even with this revision. In the end, Norway and Denmark abstained from voting. Sandler ordered von Dardel to do the same. The Scandinavians assured that they were fundamentally in agreement but did not have the same "political interests in the Far East as certain other powers." In spite of the three abstentions, the declaration was adopted on November 16. Fifteen countries voted for and one (Italy) voted against. ${ }^{60}$

Stockholm's U-turn did not go unnoticed. Just a few weeks earlier, Undén had worked energetically to achieve a resolution that would have brandished Japan's actions as illegal, but now Sweden seemed to have given up its attempts at being a "moral Great Power." It did not take long before the Chinese reaction arrived: Nanking accused the Swedish delegate of being pro-Japanese, and the envoy of the Republic of China protested in Stockholm. By way of the legation in Shanghai, the Swedish Government attempted to assuage the Chinese. It conveyed the message that Sweden fully supported the Brussels resolution but the only reason it had not voted affirmatively was that it did not belong to the inner circle of treaty powers. It was a transparent excuse, especially since a number of other small countries-Belgium, for instance-had voted for the declaration. ${ }^{61}$ There were even negative reactions from the League secretariat in Geneva, despite its officials being supposed not to take a political stance. F.P. Walters, an influential figure in the League bureaucracy, approached Envoy Westman with the question of what was behind the new Swedish standpoint. He did not get a clear answer. ${ }^{62}$

For the last round of conference negotiations that dealt with the question what actions the committee should take, the UD instructed von Dardel to passivity in all situations - except when that could be construed as tacit consent for action. Whenever needed, the envoy was supposed to cite the necessity of consulting with Stockholm. ${ }^{63}$ Certainly this policy — or lack thereof - was dictated by Sandler and not Undén. The Scandinavians could breathe a sigh of relief when it turned out that the proposed final declaration did not translate into concrete sanctions against Japan. Even the Norwegian representative voiced nothing more than a few objections to some formalities. Sandler, who in a conversation with Delbos had stressed the importance of "adaptation to realities," described the document as "totally harmless." ${ }^{4}$ The second Brussels declaration was adopted 
without any complications (except for the isolated Italian negative vote) and, on November 24, the conference was adjourned indefinitely. ${ }^{65}$

Sweden had kept such a low profile during the entire conference that von Dardel did not deliver even a single speech. ${ }^{66}$ Naturally, Chiang Kai-shek's government did not conceal its immense disappointment. Envoy Hu Shize, in Switzerland, blamed the Scandinavian passivity on bad influence from Norwegian politicians and remarked sardonically that the "common policy" of the Scandinavian delegates had confined itself to booking return tickets back home. ${ }^{67}$ The Japanese press, on the other hand, commented with surprise and joy, with Ambassador Kurusu Saburō going as far as reporting that the lack of response from the Scandinavians was an important factor behind the failure of the conference. ${ }^{68}$ Domestically, Sweden's official stance met with little resistance. Göteborgs Handels- och Sjöfartstidning held that it would have been madness to support British declarations that were not meant seriously. ${ }^{69}$ Whether it was prudence, cowardice, or just realism, the bitter fact remained that also this attempt at conflict management had spiraled into a complete fiasco. Instead of finding a way of supporting the Republic of China, the conference ended up signaling to the world that Great and Small Powers alike accepted the situation in the East and that nobody was willing to help.

\section{Sweden and the new order in Asia}

In the late 1930s, the wind was blowing in the direction of the Axis Powers. The League of Nations formally dissociated itself from the Treaty of Versailles, many states-including Sweden-recognized Italy's conquest of Ethiopia which had occurred in violation of the Covenant. Meanwhile, Germany and Italy recognized Manchukuo. Other nations, most prominently Great Britain, were expected to follow suit, although London never did so, due to the sudden onset of tension with Japan in 1939. Likewise, Sweden never recognized Manchukuo but after 1937, the center of Swedish diplomacy in China, Shanghai, fell behind the Japanese lines. Envoy Johan Beck-Friis was recalled in 1939. Foreign Minister Sandler decided not to appoint a successor, which meant that for five years, Swedish interests would be safeguarded by temporary chargés d'affaires. Stockholm decided not to open diplomatic relations with Wang Jingwei's National Government, or any regime under Japanese tutelage. ${ }^{70}$

Nevertheless, Japan's actions did cause a rethinking of some of Sweden's colonial-era policies. The famous radio address of Premier Konoe, on November 3, 1938 , in which he announced a "new order in Asia" triggered a debate about the future of the unequal treaties that were still in force-especially the trade and navigation pacts concluded with China in the decades after the Opium War. The wish to revise and eventually abolish the old treaties had been a perennial Chinese foreign policy objective. Ironically, with Tokyo laying claim to all of East Asia, that had now become Japanese policy, too. In Sweden, a top-secret investigation on possibilities to scrap the treaty with China had been carried out as early as 1937. At the core of the investigation lay the issue of extraterritoriality-the 
principle that foreigners were not subject to local law. The investigation concluded that the time for revision had not yet come, but after Konoe's speech, Swedish decision makers abandoned the colonial mindset nevertheless. ${ }^{71}$ When Sweden concluded a new trade agreement with Siam (Thailand), in 1938, it was negotiated on the basis of full equality. ${ }^{72}$

In Swedish newspapers and journals, the debate on Far Eastern affairs continued. The Japanese Government kept an eye on public opinion in Scandinavia but seemed to have refrained from all forms of political propaganda - in stark contrast to Germany, which used different forums to actively influence popular opinion. There was not even a diplomatic protest from Tokyo after the Swedish delegation had voted in favor of the League's resolutions of 1937. Tokyo most likely considered the League at that point as insignificant and did not think of dialogue with Sweden on these matters worthwhile..$^{73}$

\section{Crisis management: protecting Swedish interests in the warzones}

In terms of consular diplomacy, the warfare in China created new challenges to Swedish diplomats on the ground. Similar to natural disasters, during wartime, too, governments are obliged to protect their citizens, and they usually attempt to safeguard their interests. In the early days of the conflict, Sweden only had to save a few residents in the Chinese coastal provinces where danger was most imminent. But soon, more Swedes in the inland districts (mostly missionaries) were in dire need of protection. They got caught in the crossfire between Chinese and Japanese troops and their property got destroyed in air raids. Also, the business communities in the treaty ports saw their economic prospects deteriorate sharply as the security situation worsened. During the battle for Shanghai, a Swedish sailor died and lots of Swedish property was destroyed or damaged. The situation did not improve much once the Japanese forces had secured their positions. Foreigners were treated with suspicion and one Swedish businessman, K.G. Söderblom, was even arrested on charges of espionage. ${ }^{74}$ Emergency measures by the Swedish Government included selective evacuations (a general evacuation of all Swedes was never contemplated), protection of property, and, sometimes, diplomatic protests against belligerent actions, with which Sweden was not alone. Japan's military measures in China soon came into conflict with the interests of other European and American neutrals. The sea blockade of China, for instance, was against international law, and Western Powers were adamant not to have it. They protested the blockade and secured their concessions in China with their own navies, which became another source of conflict. For instance, when the Japanese Navy attacked and sank a US gunboat, the USS Panay, on December 12, 1937, alongside three US merchant ships on the Yangtze River, Washington protested ferociously. The case was highly sensitive because the Panay clearly displayed the US flag, which made an accidental attack improbable. At the same time, until today, there is no evidence that the sinking was the result of a Japanese Government-sanctioned strategy. Speculations remain that the attack came at the hands of rogue officers in the Japanese Navy aiming at provoking a confrontation. ${ }^{75}$ Since Tokyo did not 
condone military actions against neutrals, the Gaimushō swiftly apologized and agreed to pay indemnities, averting more bad blood with the United States. ${ }^{76}$

Stockholm, in contrast, was usually careful not to get caught in the crossfire nor anger Tokyo too much with its protests. When Japan proclaimed that its navy would inspect vessels of third (neutral) nations on the high sea to make sure that they did not carry contraband, Sweden replied in a diplomatic note that it did not view these wartime measures as anything new. ${ }^{77}$ The UD probably still remembered that this was the same policy that Britain had implemented during its blockade of Germany in World War I. Over the next three years, Sweden took pains to follow the Japanese instructions to avoid political clashes over seized vessels. That came at the price of the free movement of its merchant fleet. ${ }^{78}$

Another problem emerged in September 1937, when Japan demanded a list of Swedish cultural institutions (schools, churches, and hospitals) in China. At first, Stockholm hesitated to provide such information, fearing a negative impact for these establishments. In a note from October 4, the Foreign Ministry only answered that Swedish property had already been damaged in Shanghai and that the Cabinet reserved the right to claim indemnities. In turn, Tokyo disavowed itself from any responsibility for damage that might occur if it was not informed about the location of Swedish property in advance. In view of the real threat of bombings or looting, the UD, in the end, decided to send some lists to the Japanese that indicated Swedish establishments in war zones, but without detailed maps. The UD emphasized that since international law prohibited aerial bombardments of civilian institutions, there was no need for Japan to know the exact geographic position of churches and schools. ${ }^{79}$ It also declined to give a complete inventory, since this could be interpreted as Sweden expecting a Japanese victory of the war.

Lastly, although dangers to Swedish citizens and their property came mainly from Japan, the UD was aware that transgressions from the Chinese side could not be ruled out either. Especially since international law demanded that neutral states practice impartiality, Minister Sandler made a point of equal diplomatic practice toward both sides. A note with a warning of possible Swedish claims for indemnities was sent to both the Japanese and the Chinese Governments in March 1938. However, the nature of the aggressive war meant that most cases occurred only with Japan. In theory, this behavior did not favor any belligerent but in practice Sweden's diplomatic protests mostly benefitted China. Whereas disputes over war damage with Japan were not infrequent, wartime relation with the Republic of China was generally unproblematic. Only rarely did Swedish diplomats intervene toward Chinese authorities. ${ }^{80}$

\section{Trade}

\section{Commercial difficulties begin: from pulp to guns}

1937 had started surprisingly well for Swedish business with East Asia, booming until summer. Export and import orders from Japan and China hit record levels, 
keeping the Ostasiatiska Kompaniet so busy that, for a while, it had to charter foreign vessels to keep pace with demand. But when fighting in China ensued, Sweden's trade interests were hit hard. Especially the collapse of Shanghai's foreign trade and Japan's decision to introduce licensing of all import goods came as a shock. The flow of Swedish wood pulp to East Asia and of soy products back home was directly threatened. The waters off the Chinese coast were no longer safe and freight costs rose steeply as risk compensation fees for sailors had to be raised and insurance premiums went up. Ostasiatiska Kompaniet was particularly hard hit as it was in the midst of expanding its fleet. The M/S Nippon and $M / S$ Ningpo were to be deployed shortly-the proud result of considerable investment. ${ }^{81}$ The outbreak of warfare impacted shipowners negatively across the board. Swedish vessels in Chinese waters had to be painted scarlet red to avoid accidental bombing by the Japanese air force. In August, China announced that certain parts of the Yangzi River would be closed to foreign ships. Japan retaliated by proclaiming a blockade against all Chinese vessels between the $23 \mathrm{rd}$ and 32nd latitudes. The blockade was soon extended to include the whole coastline and Japan reserved the right to detain ships with uncertain nationality, which meant that European and American vessels had to reckon with inspections at sea. ${ }^{82}$ Assurances from Tokyo that the peaceful commerce of neutral countries would not be hindered were generally greeted with skepticism and proved, sure enough, empty as even after the conquest of the Yangzi River valley only Japanese ships were allowed to navigate freely. In August 1938, the M/S Ningpo was captured by a Japanese destroyer and the crew was interrogated. The episode drove home the point that Japan firmly established itself as regional hegemon.

However, prospects were not all rosy for the Empire. For one, Japan was running out of foreign currency. Soon, it required trading companies to accept half of all payments in yen. This was another unwelcome development for the shipowners who had little use for Japanese currency. Tokyo even demanded that import goods ought to be transported on Japanese keels and threatened to withdraw import licenses if the advice was not heeded. At the same time, the Japanese shipping line Nippon Yūsen Kaisha (NYK) wanted a larger share of the foreign market and insisted on access to Scandinavian ports. On November 19, 1938, an agreement was concluded between the NYK and the Ostasiatiska Kompaniet (together with the Danish and Norwegian counterparts), to grant the Japanese firm up to six departures per year. Already at the end of the month, the inhabitants of Gothenburg could watch the "Yasukuni-maru" loading 1,500 tons of rayon pulp at their harbor. ${ }^{83}$

The controversial arms trade with China also continued after 1937 and threatened to sour relations between Stockholm and Tokyo further. The Chinese imported gunpowder and especially the much sought-after Bofors anti-aircraft guns. The weapons export was legitimized by the League of Nations resolutions of 1933 and 1938, which stated that China had the right to access foreign armament industries, since it was not in breach of the Covenant. For Sweden, this was a convenient rhetoric to justify uninterrupted income from the lucrative arms trade. ${ }^{84}$ Sweden was far from the only arms dealer in the region: the German 
Reich and Soviet Russia principally sold weapons to China, American companies sold to Japan, and Great Britain to both sides simultaneously. ${ }^{85}$ Besides, Sweden also assisted China with medicine, healthcare articles, and surgical equipment. ${ }^{86}$ The self-interest characteristic of Swedish companies went both ways. On September 4, 1937, Sandler had a talk with Japanese Envoy Kuriyama and discussed the naval blockade of China when the delicate question about weapons exports to Chiang's regime surfaced. In reply to Kuriyama's inquiry whether Swedish vessels supplied arms to China, Sandler assured that there were no such transports as far as he knew. That was a very evasive answer since Sandler was aware that most Swedish arms were simply transported on board German ships. The envoy did not ask further questions but according to the notes of the UD, Sandler was prepared to defend Sweden's right to give export licenses to the weapons industry. ${ }^{87}$ The Japanese side was well aware that Sweden contributed to China's defense, but it was also clear that its companies sold a range of important articles to the Japanese armaments industry: iron and steel products, including ball bearings. ${ }^{88}$ Tokyo, therefore, never requested the end of Swedish trade with its enemy, since, if applied impartially, this would have damaged Japan's interests too. In September 1939, the arms trade with China came to an end nevertheless, after Sweden's national emergency laws reserved arms and munitions for domestic defense. Orders from foreign customers were annulled. Besides, the sea journey to Asia became hazardous after the British and French colonial empires entered the war in Europe. In February 1940, the Ostasiatiska Kompaniet declared that they intended to send Swedish gunpowder to China on the steamer Formosa, but just a few weeks later, the extension of the war zone and the laying of a mine barrage in Skagerrak paralyzed Swedish sea traffic. The last known Chinese request for Swedish arms arrived there on September 27, 1940. ${ }^{89}$

\section{Trade with Japan}

Despite the deterioration of the situation on the high seas, Swedish policymakers remained optimistic in the beginning about global trade. A 1938 report by the export trade commission even held that outside of Europe, the United States, Argentina, and Japan would be Sweden's most important export markets. ${ }^{90}$ The hopeful assessment for Japan was mainly based on record trade numbers of the previous year when export numbers had more than doubled. In reality, however, trade was shrinking. On the one hand, traditional Japanese exports like textiles were not important to the war economy after 1937, and were produced at lesser quantities, which also meant that less textiles were available for export. ${ }^{91}$ On the other hand, import hurdles multiplied after the warfare with China started, making it harder for Swedish goods to reach consumers in the East. Japan used to be a market where Swedish business was able to operate rather freely, without restrictions like quotas or currency controls, but the warfare upended these conditions. Not only did Japan start limiting imports through a new licensing system but there was a sharp shift in the relative importance-and hence of ordersof different product categories. Until 1937, Japan had mostly imported paper, 


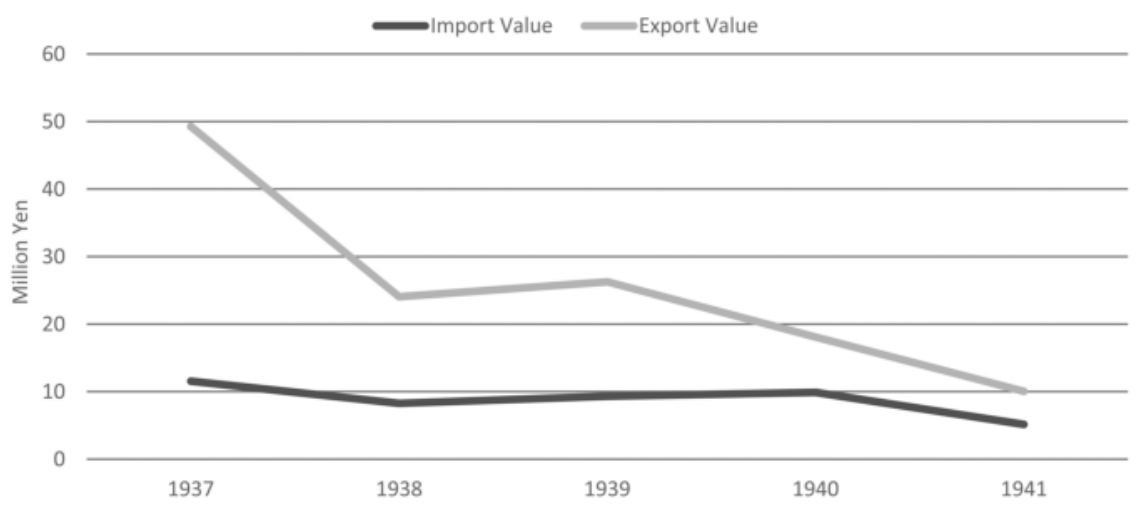

Figure 4.1 Swedish imports and exports to Japan 1937-1941. Source: Data from Honma, Nippon keizai tökeishü 1868-1945, 35-47. Note: In million yen.

cardboard and pulp (worth SEK 24.6 million), "base metals and products made from them"-mostly ball bearings (SEK 17.3 million)_and "machines and tools" (SEK 4.5 million). ${ }^{92}$ In October, the currency restrictions almost put an end to imports of timber and its derivates, as well as to cellulose imports for paper manufacturing. As the nationalization of Japan's productive industries progressed, imports of nonessential goods were halted to prioritize the needs of the armament industry. As a result, Swedish-Japanese trade value in 1938 fell by 50 percent. Statistical figures reveal the extent of the commercial decline in East Asia: 143,000 tons of goods had been consigned to China and Japan in 1937. In the following year, this amount plummeted to under 38,000 tons. Although imports increased somewhat, an overall slowing of trade set in, and, in 1939, the grounding of Swedish vessels could not be avoided. In addition, the outbreak of the European war meant further troubles to Swedish shipping companies. In spring 1940, the Skagerrak Barrage put an end to "normal" transoceanic trade (including Japanese shipping to Scandinavia). ${ }^{93}$

Since Sweden was not the only country hit by these changes, a business magazine reported as late as 1939 that out of all European economies, Sweden was still the fourth-largest exporter to the Japanese market. ${ }^{94}$ This was not least due to its most important contributions to the war industry, which were ball bearings. They are used in weapon-manufacturing machines, as well as in cannons, machine guns, tanks, submarines, and fighter planes. ${ }^{95}$ Demand was strong and the already dominant position of SKF on Asian markets allowed the company to build a de facto monopoly on the product by undercutting local market prices-a practice that Envoy Widar Bagge once called "Japanese methods" that was coupled with generous credits to the company's customers. ${ }^{96}$ But SKF was an exception. Overall, Swedish companies struggled in the emerging nationalistic environment in which mercantilist ideas celebrated a comeback. Envoy Bagge summarized the situation in September 1937 in a telegram to the UD as follows: 
(...) currency restrictions were further tightened for all goods which are not necessary for military purposes STOP Imports are largely discontinued STOP Relevant shipments do not take place unless a currency permit is available. (...) STOP Prospects should continue to be good for Swedish silk, pulp and cellulose products as they are necessary for the Japanese industry. ${ }^{97}$

Ideological nationalism had reached the business world. Bagge's restrained optimism for Sweden's core exports turned out to be too optimistic. Even wood, pulp, and paper commodities quickly fell prey to the new restrictions and almost vanished in trade statistics from 1938 onward. And Japanese authorities were not only hell-bent on reducing the chronic trade deficit but also to stimulate domestic production of machines and indigenous technology to achieve autarchy within the "Yen-bloc" of Japan, Manchukuo, and occupied China. Lucky for Swedish companies, these goals were never fully attained, allowing for at least some business to continue. The Japanese Government also realized that too drastic a limitation on imports might hurt the acquisition of raw materials and thus hurt wartime production. ${ }^{98}$

As many Japanese customers canceled purchase orders, Swedish exporters had to get used to spending more and more time at government ministries in Tokyo to cultivate relations with key decision makers. This meant regular visits to the Trade Bureau of the Gaimushō or trips to the Finance Ministry, which could grant import licenses and currency permits. This posed considerable strain on the companies, which had been used to business practices of the private sector, but not to negotiations with Japanese public administrators. On top of that came the language barrier. Western corporate leaders were often not able to communicate in Japanese. Their Japanese counterparts were usually conversing with them in English. Thus, once important trade matters came under the influence of military officers who did not master foreign languages, great difficulties arose for shipment or price negotiations. ${ }^{99}$ Gadelius, for instance, delegated sensitive issues to native employees who were put in charge of contacting the authorities. In its archives, there exists an unusual memorandum about a salesman, Aoki Tosezō, who claimed that he went to the Ministry of Finance, wearing his military uniform and threatening harakiri if he was refused a currency permit, which he needed to secure imports of Sandviken's piano wire-a product used in Japanese machine guns. ${ }^{100}$ In order to eliminate such problems, various kinds of solutions were contemplated. Gadelius, again, is a good example of the adaptability of some foreign firms. Between 1932 and 1938, the firm increased its machine exports to Japan nine-fold. When Tokyo introduced its import restrictions, the trading house circumvented the protectionist quotas by moving its production to Japan itself. The purchase of a factory in Kamata (between Tokyo and Yokohama) made it possible to produce a multitude of goods licensed from Swedish manufactures locally without forfeiting profit. ${ }^{101}$

In the chilly climate of nationalistic trade negotiations, statistics became a battlefield and since bilateralism was becoming a new ideal, it also became more important to demonstrate that business with a given nation did not suffer from 


\section{Fading protest}

too much imbalance. This was one of the reasons behind the decision of Sweden's statistical bureau to alter the calculation basis of its trade statistics in 1936. In the case of transactions with Japan and China, the effect was a marked rise in imports. Articles were now classified according to country of origin rather than country of purchase. This obviously helped Sweden rebuff criticism that it sold too much and bought too little in East Asia. A substantial amount of the imports from those countries was mediated through third nations. As for Japan, the rearrangement of statistics meant that the import value would be SEK 14.8 million compared to 10.6 million according to the old model. This way of reckoning made it necessary to make corresponding changes in the export statistics. Exports would now be registered on the basis of country of consumption, rather than country of sale, but here the value was almost the same as previously, standing at SEK 26.5 million instead of SEK 26 million. The reshuffle of statistics had a particularly dramatic effect on the imports from China. Under the new system, their value rose from SEK 1.5 million (1935) to SEK 28.2 million (1936), a twenty-fold increase! ${ }^{102}$

Even before 1937, Tokyo had frequently advocated for trade reciprocity but after warfare in China broke out, its diplomats started to threaten that their government would limit imports from Sweden if Stockholm did not buy more goods from Japan. Swedish representatives usually countered that prices of Swedish articles were already low and profit margins slim and that the quality of Swedish products would be difficult for Japan to substitute by anything else. ${ }^{103}$ Stockholm's diplomats used this argument also to pacify their Japanese counterparts when they demanded that Swedish trade with the enemy government in Chongqing stopped. When Envoy Johan Beck-Friis in Shanghai met with the Japanese ambassador, Tani Masayuki, he simply claimed that Swedish exports to China were of little value. Exports to Japan, on the other hand, were "abundant and highly beneficial to Japan." ${ }^{104}$ These arguments stuck at least partially. Although sales fell after the all-time high of 1937, they soon stabilized at approximately the same level as during the good years before the warfare in China. During 1938, products for over SEK 26 million were sold to Japan, while Swedish imports accounted for SEK 15.6 million-which was more than its commerce with the much closer and bigger Soviet Union. ${ }^{105}$

\section{Trade with Manchukuo}

The Manchurian breakaway state had serious internal problems. The legitimacy of the government in Hsinking (Changchun) was questioned inside and outside the country. In several parts of Manchukuo, armed resistance movements sprang up against Japanese rule. Meanwhile, the authorities and foreign advisors were carrying out hectic modernization programs. New infrastructure was planned for this rather neglected northeastern corner of China. Heavy industry expanded. At the same time, foreign firms arrived one after another, thinking about Manchukuo in terms of market prospects. To them, the Empire was a promising field for investment and sales. ${ }^{106}$ In 1937, the General Export Association of Sweden contemplated an "information and propaganda tour" across the country. Almost all 
Swedish companies-SKF, Gadelius, Kjellberg, and Ekman — set up representation offices in Manchukuo. As we have seen above, in these circles it was common to praise the Empire for "order" and "progress," whereas they complained about the "bandits," with whom they meant local resistance fighters. ${ }^{107}$

In 1937, according to estimates from Stockholm, the value of Swedish exports to the new state amounted to around SEK 1 to 1.5 million. Almost certainly this figure was too low because many Swedish articles arrived after stopping first in Japan. The legation in Tokyo talked about a strong upswing in trade, and Gadelius alone claimed that they had delivered cellulose machines for SEK 2 million to five different Manchurian paper mills. ${ }^{108}$ Of course, these numbers were not official because, "officially," there were no economic relations between Sweden and Manchukuo. But just as Manchukuo existed de facto, the state was dealt with by the trading companies de facto, which lead to the awkward situation that Manchukuo trade numbers had to be subsumed in the figures for China. Naturally, that was not a satisfying situation for companies that relied on adequate statistics. In 1936, the General Export Association petitioned the National Board of Trade to make the commerce visible, but it took the parliamentarian treaty committee two years to agree. Even so, the committee had to be careful; it emphasized that a separate statistical column for Manchukuo would not constitute its diplomatic recognition. It was a delicate balancing act between trade and diplomacy but, luckily, there had been similar cases: Algeria and the Canary Islands, for example. Therefore, beginning in 1939, trade with Manchukuo appears openly visible in Swedish statistical abstracts. The Tokyo legation had guessed that actual trade amounted to about SEK 4 million, a belief that was now confirmed. ${ }^{109}$ Just as with Japan, imbalance persisted in the Swedish trade with Manchukuo-but in reverse to Japan: due to the demand for soybeans Sweden bought much more products from Manchukuo than it sold. As we have seen in the last chapter, Stockholm used this argument when negotiating with Tokyo. ${ }^{110}$

In terms of exports, Sweden's main client in Manchukuo was the mining industry, followed by the chemical and heavy industries. The Manchurian ministries and various army institutions were responsible for further orders. Early in 1937, a five-year plan was announced by the Emperor's government. From that moment, Swedish firms experienced a swift rise in commissions. Among the most popular items were machines for paper and cellulose manufacturing, followed by mining drills and measuring instruments. ${ }^{111}$ Although the introduction of import restrictions in September 1937 signaled bad news for business, all in all, the policy did not herald dramatic change. Soon, managers Björn Prytz and Gösta Guston from SKF had concluded a ball-bearing agreement with Hsinking. They also tried to help other Swedish enterprises to get preferential treatmentthat one, however, in vain. ${ }^{112}$

In 1938, the German Reich and a number of other nations recognized Manchukuo. This weakened the bargaining strength of countries that did not entertain diplomatic relations with the puppet state. Swedish firms were now often excluded from deals if there were German competitors. The imperial authorities recommended Manchurian companies to buy iron and steel from the German 


\section{Fading protest}

Krupp Company and others. The Swedes were also in an inferior position to large American enterprises that could arrange cashless compensation deals. However, all foreign firms complained about the red-carpet treatment given to Japanese businesses. ${ }^{113}$ Generally speaking, Western corporations in Manchukuo practiced business as usual and competed fiercely, remaining rather unconcerned about politics and warfare.

\section{Summary}

A major change in Swedish relations with East Asia came in July of 1937, when the Marco Polo Bridge incident sparked full (but undeclared) warfare between China and Japan. The Japanese army attacked Chinese military positions and started assaulting the Government of Chang Kai-shek, raiding cities and attacking the capital Nanking, which fell on December 13, and subsequently subjugated to some of the worst atrocities of the war. These developments were closely followed in Sweden, but public perception was mixed, ranging from utter indignation that even produced attempts at a private boycott movement, all the way to tacit approval by the business community and anti-colonialists. Although the League of Nations made another attempt at pacifying the belligerents, Japan simply refused to participate. The League condemned Japanese actions as violations of both the Kellogg-Briand Pact and the Nine-Power Treaty, but the only concrete effect that this had was that Japan's Privy Council cut the remaining ties to nonpolitical organs of the League on November 2, 1938. ${ }^{114}$ It was during this episode that Swedish foreign policy changed noticeably not only toward Japan but toward collective security in general. While its diplomats in Geneva initially still tried to convince the League of a meaningful stance that might imply sanctions or even military aid to China, the unwillingness of Great Powers to even consider labeling Japan as a perpetrator against Article XVI wiped away the remaining internationalist sentiments in the UD. In the following conference in November, under the provisions of the Nine-Power Treaty, Sweden's lack of engagement and enthusiasm bordered at sabotage. Within two months, the UD had shifted from engagement to apathy which was an expression and consequence of a major foreign policy realignment to "strict" neutrality, as we shall see in the next chapter.

Apart from the obvious failure and humiliation of the Swedish internationalist position, the most impactful problems that the new situation created had again to do with trade. Not only because the markets in China disappeared, or fell under Japanese control, but because the Japanese blockade of the Chinese coastline made trading routes unsafe. Shipping became dangerous to the point that Swedish companies had to offer war risk allowances to sailors on dangerous routes. Similarly, Swedish missionaries and merchants in China came under pressure from both the Japanese and Chinese sides. Many had to be evacuated in 1938 and 1939. Trade with China naturally suffered from these conditions. Exports fell from SEK 15.4 million in 1937 to SEK 8 million a year later and to SEK 6 million in 1939. ${ }^{115}$ Import numbers remained stable at around SEK 31 million but that 
was only because the official statistics were still counting Manchurian soybean as a product of China. The actual total sum of imports for 1939 was SEK 5.2 million. That was only a third of what Sweden at the same time imported from Manchukuo (SEK 15.6 million). Trade with Japan also took a sharp downturn. Whereas 1937 had been the most outstanding year for exports, with SEK 47.8 million, the number plummeted back to SEK 26.3 million in 1938. This was not solely the effect of war-related trade hurdles. In 1937, the Japanese parliament enacted laws to eliminate trade deficits and spur domestic production of vital goods that would decrease the Empire's dependence on foreign products. Japan's industries came under tight control, resembling a nationalization process. This meant that Swedish trading companies had to adapt not only their merchandise but their entire business practice, negotiating more with Japanese ministries than with private-sector partners. In the wake of this wind of economic nationalism, the products that survived the wrath of the regulators were those that were difficult for Japan to replace. Ball bearings, for example, on which SKF had a near monopoly and high-quality machinery. Those were needed in even higher quantities due to the warfare in China. ${ }^{116}$ That, on the other hand, seriously impeded Swedish interests there. Ever since the beginning of open warfare, Bagge had to protest to the Gaimushō in the name of Swedish companies and the consulate in Shanghai, when Japanese attacks struck their property or when Japanese forces confiscated them. Usually, his protests were of little help. ${ }^{117}$ The good years for Swedish trade with East Asia were over.

\section{Notes}

1 Rana Mitter, China's War With Japan, 1937-1945: The Struggle for Survival (London: Penguin Books, 2013), 73-96.

2 How many soldiers, city-dwellers, and war refugees were slaughtered will never be exactly known and is a hotly contested topic among historians.

3 Ibid., 96-140, 62-67.

4 Declaration of the Japanese Government, regarding the invitation to the Brussels Conference, October 27, 1937 (GMS/S, A.1.1.0.30, vol. 12).

5 After 1933, Japan had continued to participate in some of the nonpolitical committees of the League. See Walters, A History of the League, 731-738; Arata Ninagawa, Sino-Japanese War and Nullified Nine Power Treaty (Tokyo, 1937).

6 Mitter, China's War With Japan, 86-87, 162-167, 71-75.

7 Boheman, På vakt, 35; Krister Wahlbäck, Finlandsfrågan i svensk politik 19371940 [The Finnish question in Swedish politics, 1937-1940] (Stockholm: Norstedt, 1964), 341; Documents on British Foreign Policy, 1919-1939, Second Series, vol. XII, London 1972, no. 101 (April 6, 1935), 803.

8 Sandler in Parliamentary Records (PR) 1936 AK, no. 4, 25; 1938, AK no. 4, 95-96. Sandler also referred to his earlier statement at the disarmament conference in 1934. Sweden reserved the right to choose the road of neutrality again (PR 1936 FK, no. 3, 80).

9 Sandler at the March 4, 1937 session of the Advisory Council on Foreign Affairs (UDA, 2210.03.1, HPl, N, XI).

10 Ottosson, Handel under protest, 290.

11 Military attaché report 434/F (Försvarsstabens Arkiv [Archives of the Defence Staff], Series Ö I:10); Redogörelse, 1939, 58-60, 62. According to Widar 
Bagge, British military experts were convinced that Japan would only have the capacity to fight for one year in China. See Bagge to UD, September 14, 1937 (UDA, 2210.03.1, HP37, B, I).

12 Redogörelse, 1938, 1.

13 Ibid., 60.

14 Ibid., 56-57; Redogörelse, 1939, 63; Redogörelse, 1940, 115-117.

15 Rickard Sandler, Strömväxlingar och lärdomar: Utrikespolitiska anföranden, 1937-39 [Changing currents and lessons learned: speeches on foreign policy, 1937-39] (Stockholm: Tiden, 1939), 169, 305. See speeches in August 1938 and May 1, 1939.

16 Ottosson, Handel under protest, 283-284.

17 Pearl S. Buck, The Good Earth (New York: John Day, 1931).

18 Stockholms-Tidningen [The Stockholm Gazette], August 17, 1937.

19 Nya Dagligt Allehanda, July 15, 1937. Cf. with “Aktuellt utifrån” [Actualities from abroad], Aftonbladet October 9, 1937.

20 Den Svenske Nationalsocialisten, September 29, 1937.

21 Editorials in Göteborgs Handels- och Sjöfartstidning, July 13 and 31, October 12, 1937; Svenska Dagbladet, July 13 and 30, 1937; Svenska Morgonbladet, August 17, 1937; Social-Demokraten, July 14 and August 19, 1937; Nya Dagligt Allehanda, July 15 and 29, 1937.

22 Editorials in Göteborgs Handels- och Sjöfartstidning, August 14 and December 29, 1937.

23 See two speeches by Lindhagen in PR 1938, FK No. 1, 12, and No. 24, 24.

24 Ottosson, Handel under protest, 281.

25 Ibid., 294-295. For the resolution of September 28, see League of Nations, Doc. A.56.1937.VII in (UDA, 2210.03.1, HP37, A, II).

26 Social-Demokraten, August 19, October 5, and December 16, 1937; the editorial from October 5 is headlined "Japan on clay feet" in Svenska Morgonbladet, August 24, October 9 and 14, 1937.

27 Elin Wägner, "En japansk tragedi” [A Japanese tragedy], Social-Demokraten, January 22, 1938, 16.

28 Svenska Morgonbladet, "Bojkotten mot Japan” [The boycott against Japan], October 14, 1937; Social-Demokraten, "Japan-bojkott stoppar kriget på 6 månader" [Japan boycott will stop the war in six months], December 16, 1937; Frithiof Thunborg, Statement in the minutes from the executive board of the Swedish Committee of the International Peace Campaign (Svenska kommittén av Världssamling för fred, A 1:1).

29 See, e.g., Göteborgs Handels-och Sjöfartstidning, "Uppmaning till bojkott av japanska varor" [Summons to boycott of Japanese articles], October 5, 1937; Social-Demokraten, "Avstå från inköp av japansk varor" [Abstain from purchasing Japanese articles], October 9, 1937; Svenska Morgonbladet, "Stanley Jones' vädjan till de kristna väcker djup anklang” [Stanley Jones' appeal to Christians resonates deeply], October 12, 1937.

30 Svenska Morgonbladet, "Den svenska ungdomen och Tokiospelen" [The Swedish Youth and the Tokyo Games], July 5, 1938; Edward Seidensticker, Tokyo Rising: The City Since the Great Earthquake, (Tokyo: Knopf, 1990), 102-103. A motion demanding a boycott of the Tokyo Olympics was rejected by the Metal Workers' Union, see Landssekretariatets protokoll [Minutes of the Headquarters Staff] February 28, 1938, 80 (Archives of the National Federation of Labor).

31 The headline of Göteborgs Handels- och Sjöfartstidning on October 9, 1937, read, "Our exports to Japan have doubled." In the issue of October 20, Admiral Hasegawa emphasized that a boycott would never change his country's determi- 
nation to win the war ("Japan ger sig ej innan Kina kuvas" [Japan will never rest before China is subdued]).

32 Nya Dagligt Allehanda, "Istället för sanktioner" [Instead of sanctions], October $7,1937$.

33 Gösta Bagge, Politiska tal àr 1937 [Political speeches in 1937], (Stockholm: Egnellska Boktryckeriet, 1937), 145. The speech was held in the city of Borlänge in October.

34 Parliamentary Records 1938, AK No. 16, 23-24, No. 25, 72 (Brädefors); Bevillningsutskottet [Committee on Appropriations], Report No. 5 (1938); Första Lagutskottet [First Committee on Legal Affairs], Report No. 27 (1938).

35 See, e.g., Göteborgs Handels- och Sjöfartstidning, "Idag" [Today], October 8, 1937; Svenska Morgonbladet, "Barbariskt säga hemvändande missionärer om japanska kriget" [Barbaric, returning missionaries say of the Japanese war], December 30, 1937; and Svenska Morgonbladet, "Hela Jangtsedalen skövlad av japanska invasionen" [The whole Yangtze valley devastated by the Japanese invasion], March 6, 1939. The only early mention of the Nanking massacre appears in Svenska Dagbladet, "Japanerna massavrätta och plundra i Nanking" [The Japanese mass executing and plundering in Nanking], December 18, 1937. The full extent of the massacre was revealed by Gustaf Fredén, "Det totala kriget. Den japanska terrorn i Kina" [Total war. The Japanese terror in China], in Svenska Morgonbladet, October 18, 1938. The article referred to the British journalist H. J. Timperley. Explorer Johan Gunnar Andersson also described the massacre in Under brinnande krig [In the thick of a raging war]. It was reviewed in Social-Demokraten, December 18, 1938, but the Nanking massacre is not mentioned.

36 Björn Prytz, who had toured the region in autumn 1937, held that Swedish business interests in Shanghai did not view the future "too pessimistically," see his "Något om affärslivet i Fjärran östern" [About business in the Far East], Svensk Export 1938, 95.

37 Letter from Sigurd Yngve Eurén, November 20, 1938 (UDA, 2210.03.1, HP37, A, XI). The address is not mentioned in the report to the headquarters of Ekman \& Co., November 22, 1938 (HP37, A, XI) but is probably the Swedish legation in Shanghai.

38 Thune in Nya Dagligt Allehanda, June 22, 1938, and March 10, 1939.

39 Gösta Guston, "Japan, Kina och Manchukuo" [Japan, China and Manchukuo], Svensk Tidskrift, 1939, 667-669.

40 Ibid.

41 Minutes of the Swedish legation in Tokyo, October 5, 1937 (UDA, 2210.03.1, $\mathrm{H} 6, \mathrm{Xj} / 263, \mathrm{~V})$.

42 Ibid.

43 Bagge to Sahlin, March 30, 1938 (UDA, 2210.03.1, HP64, Xm).

44 Japan Advertiser, "Swedish Magnate Arrives on Yacht," February 24, 1938; Japan Times \& Mail, "Sweden Seeking Barter Contact with Hsinking," March 4, 1938; Tökyō Nichi Nichi Shinbun, "Large-Scaled Trade Negotiations on Semi-Barter System in Progress Between Japan and Sweden," March 12, 1938 (English translation in UDA, 2210.03.1, HP64, Xm); Bagge to Sahlin, April 7, 1938 (UDA, 2210.03.1, HP64, Xm).

45 Göteborgs Handels- och Sjöfartstidning, "Sverige får ej bli ett Mandsjukuo" [Sweden must not become a Manchukuo], July 12, 1937.

46 Beck-Friis to the Foreign Ministry, Report, November 25, 1938 (UDA, 2210.03.1, HP37, A, XII).

47 Westman (Geneva) to the Foreign Ministry, Report, September 2, 1937 (UDA, 2210.03.1, HP37, A, I). 
48 Foreign Minister Sandler's presentation at the Cabinet meeting, October 22, 1937 (UDA, 2210.03.1, HP37, B, I).

49 The quantity of Swedish source material on the conflict also supports this argument. While the Manchurian crisis generated a flurry of internal communications, the new Sino-Japanese conflict produced much fewer official documents. That is despite the fact that this time a total war between two major military powers had started, which was knowingly more destructive and more violent than the previous "swift" occupation of Manchuria.

50 Westman (Geneva) to UD, Report, October 3, 1937 (UDA, 2210.03.1, HP37, B, I).

51 Westman (Geneva) to UD, Report, October 8, 1937 (UDA, 2210.03.1, HP37, B, I); Redogörelse, 1938, 60.

52 Redogörelse, 1938, 62.

53 Undén in Foreign Ministry, Memorandum (UDA, 2210.03.1, HP37, B, I).

54 Beck-Friis to Foreign Ministry, Memorandum (UDA, 2210.03.1, HP37, B, I).

55 Diplomatic reports to Stockholm from Belgium, Denmark, and Norway, see von Dardel, October 30, Hamilton, October 10 and Ståhle, November 2, 1937 (UDA, 2210.03.1, HP37, B, II).

56 Westman (Geneva) to UD, Report, October 25, 1937 (UDA, 2210.03.1, HP37, B, I).

57 Hamilton to UD, Report, October 11; Foreign Minister Sandler's presentation at the Cabinet meeting, October 22, 1937 (UDA, 2210.03.1, HP37, B, I).

58 United States. The Conference of Brussels: November 3-24, 1937. Convened in Virtue of Article 7 of the Nine-Power Treaty of Washington of 1922 (Washington, DC: Government Printing Office, 1938).

59 Von Dardel to UD, Reports, November 13 and 14 (UDA, 2210.03.1, HP 37, B, III); see also Beck-Friis, Memorandum, November 15, 1937 (ibid.) and Redogörelse, 1938, 62-63.

60 Von Dardel to UD, November 16, 1937 (UDA, 2210.03.1, HP37 B, IV).

61 Chinese Foreign Minister to the Legation in Stockholm, Telegram, November 19; Swedish Foreign Ministry to Legation in Shanghai, Telegram, November 20, 1937 (UDA, 2210.03.1, HP37, B, IV).

62 Westman (Geneva) to UD, November 26, 1937 (UDA, 2210.03.1, HP37, B, IV).

63 Instructions from UD, November 20, 1937 (UDA, 2210.03.1, HP37, B, IV).

64 Von Dardel to UD, November 22; Sandler, Memorandum, November 23 (UDA, 2210.03.1, HP37, B, V).

65 Von Dardel to UD, November 24, 1937 (UDA, 2210.03.1, HP37, B, V).

66 The Conference of Brussels, November 3-24, 1937, Convened in Virtue of Article 7 of the Nine-Power Treaty of Washington of 1922.

67 Westman (Geneva) to UD, Report, December 16, 1937 (UDA, 2210.03.1, HP37, A, V).

68 Tökyō Asahi Shinbun, "Keishikiteki sengen happyō de sankakoku no taimen koto" [Participating nations save face by formal declaration], "Kyūkakoku kaigi no munō kokuhaku" [The Nine-Power Conference admits its incompetence], November 17, 1937; Kurusu, Brussels, to Foreign Minister Hirota, Report, November 25, 1937 (GMS/S, A.1.1.0.30-32).

69 Göteborgs Handels- och Sjöfartstidning, "Statistens roll och åskådarens" [The roles of the supernumerary and the spectator], November 25, 1937.

70 Ottosson, Handel under protest, 302-304. For Sweden's recognition of Italy's African empire, see UDA, 2210.03.1, HP35, A, X.

71 The investigation is preserved in UDA, 2210.03.1, HP64, Xk, XII.

72 In the following year the country was renamed "Thailand." 
73 Ottosson, Handel under protest, 314-315. Swedish opinion was collected in the Shīkan Jiho, a weekly information pamphlet from the Information Bureau at the Japanese Foreign Ministry. See, for example, no. 151 (October 19, 1937), 17 and 52 (GMS/S, A.1.1.0.30, Vol. 22).

74 Ottosson, Handel under protest, 258.

75 Douglas Carl Peifer, Choosing War: Presidential Decisions in the Maine, Lusitania, and Panay Incidents (New York: Oxford University Press, 2016), 215.

76 United States, Peace and War: United States Foreign Policy 1931-1941 (Washington, DC: Government Printing Office, 1943), 52-53.

77 Redogörelse, 1938, 59.

78 Arakawa Ken'ichi, "Japanese Naval Blockade of China in the Second SinoJapanese War, 1937-41," in Naval Blockades and Seapower: Strategies and Counter-Strategies 1805-2005, ed. Bruce A. Elleman and S.C.M. Paine (Oxon: Routledge, 2006).

79 Redogörelse, 1938, 57-59; Ottosson, Handel under protest, 291-293. The first Swedish list was sent to the Japanese Government on November 6, 1937 (UDA, 2210.03.1, HP 37, A, IV).

80 Redogörelse, 1939, 63. One of the few occasions when Sweden protested to China was in autumn 1938 when the Shanghai legation pointed out that Chinese soldiers illegally had ensconced themselves in a Swedish missionary station. See: Beck-Friis, August 3, 1938 (UDA, 2210.03.1, P83, Xk, VIII). The intervention brought swift results. See: Kronvall to UD, September 8, 1938 (UDA, 2210.03.1, P83, Xk, IX).

81 Ostasiatiska Kompaniet, "Förvaltningsberättelse, balansräkning och revisionsberättelse över 1937 års verksamhet" [Administrative report, balance sheet account, and audit report for 1937] (Archives of the East Asian Company, Gothenburg).

82 Shina jihen kankei köbyöshü [Collections of proclamations concerning the China incident], volume I, 79, 105, and 121 (GMS/S, A.1.1.0.30-51).

83 Ostasiatiska Kompaniet, "Förvaltningsberättelse, balansräkning och revisionsberättelse över 1938 års verksamhet" [Administrative report, balance sheet account, and audit report for 1938]; Board Meeting Minutes, 1934-1938 (Archives of the East Asian Company, Gothenburg).

84 UD to Bagge, Telegram, December 14; H. Beck-Friis to Bagge, December 17, 1938 (UDA, 2210.03.1, HP 64, Xk, IV).

85 Ottosson, Handel under protest, 309-310.

86 Prince Carl of Sweden to the International Red Cross Committee, Geneva, November 6, 1937 (UDA, 2210.03.1, HP 37, D).

87 Hans Beck-Friis, Memorandum, September 4, 1937 (UDA, 2210.03.1, HP 37, A, I).

88 GMS/S, A.1.1.0.30-6-1, Vol. 1. The most specific document is a telegram to Tokyo from Consul Kuga in Rangoon, May 27, 1939, concerning Swedish arms transports to Chiang Kai-shek by way of the Burma Road. According to his report, weapons and munitions were shipped to Burma by M/S "Nagara" of the Swedish East Asian Company. The Swedish arms trade with China had already been disclosed by The New York Times, September 21, 1938.

89 Adolf Croneborg, Memorandum and other documents, April 17, 1940 (UDA, 2210.03.1, HP 64, Xk, IV).

90 Export Committee, Betänkande med utredning och förslag angående åtgärder till den svenska exportnäringens främjande, avgivet av 1938 års exportutredning [Report with investigation and proposal concerning measures for the furthering of the Swedish export business, presented by the Export Committee of 1938] (Stockholm: Norstedt, 1938), 12-13. 
91 Ottosson, Handel under protest, 260.

92 Gaimushō Tsūshōkyoku, ed., "Suēden tainichi bōeki" [Sweden's trade with Japan], in Kaigai keizai jijö [Overseas economic conditions] 1939, 158-160.

93 Ibid. The column "Weapons and munition" is empty.

94 Svensk Export, 1939, 230; Traktatberedningen, PM angående de svensk-japanska handelsförbindelserna [Treaty Committee, memorandum concerning Swedish-Japanese trade relations], June 14, 1938 (UDA, 2210.03.1, HP 64, $\mathrm{Xj}, \mathrm{I})$.

95 Kent Olsson, Göteborgs historia [The history of Gothenburg] vol. 3, (Stockholm: Nerenius \& Santérus 1996), 129.

96 Bagge to Hägglöf, January 28, 1941 (UDA, 2210.03.1, HP 64, Xm).

97 Bagge to UD, Telegram, September 10, 1937 (BA, 230033.2, E2, I).

98 Minutes from a meeting with businessmen in the Swedish legation in Tokyo, October 5, 1937 (UDA, 2210.03.1, H 6, Xj, V); Bagge to UD, November 23, 1938 (Svenska Handelsdepartementets arkiv [Archive of the Swedish Ministry of Trade], F II aa: 203); Bagge to UD, January 25, 1939 (UDA, 2210.03.1, H 100, Xj); Wistrand (Tokyo) to UD, September 28, 1939 (UDA, 2210.03.1, H6, $\mathrm{Xj}, \mathrm{V})$.

99 Bagge to Sahlin, November 30, 1937, and minutes from the meeting, October 5, 1937 (UDA, 2210.03.1, H6, Xj, V).

100 Gadelius' archive, vol. 191.02.025.

101 Brauns, Gadelius \& Co-50 ar i Japan 1907-1957, 57. The Kamata factory was demolished in an air raid at the end of World War II.

102 Sveriges officiella statistik, Handel, Berättelser för år 1935 och 1936 av Kommerskollegium [Official Statistics of Sweden, Trade, Reports for the years 1935 and 1936 by the National Board of Trade].

103 Minutes from the meeting, October 5, 1937 (UDA, 2210.03.1, H6, Xj, V); Sahlin, "Swedish-Japanese trade relations," Memorandum, May 10, 1938 (HP 64, Xj, I); "Ny exportkampanj i Japan" [Fresh export drive in Japan], Svensk Export, 1938, 109.

104 Beck-Friis to UD, May 13, 1938 (UDA, 2210.03.1, HP 37 A, VIII).

105 Sveriges officiella statistik, Handel, Berättelse för àr 1938 av Kommerskollegium [Official Statistics of Sweden, Trade, Reports for the years 1935 and 1936 by the National Board of Trade].

106 Ottosson, Handel under protest, 264.

107 Bagge to Sahlin, September 10, 1937 (UDA, 2210.03.1, HP 64, Xm). PM concerning Swedish trade with Japan, Manchukuo, Siam and Java, Informal, October 18, 1937 (HP 64, Xj, I); Ingemar Gerhard, Problem rörande Sveriges utrikeshandel 1936/38 [Problems related to Swedish foreign trade, 1936-38] (Gothenburg: Elanders Boktryckeri, 1948), 399; cf. C. Lamberth, National Board of Trade, to I. Tennberg, September 19, 1935.

108 Traktatberedningen [Treaty preparations, Memorandum] June 14, 1938 (UDA, 2210.03.1, HP 64, Xj, I).

109 Ibid.; Ribbing, UD to Bagge, July 8, 1938 (HP 64, Xj, I).

110 Bagge to Sahlin, July 5, 1937 (UDA, 2210.03.1, H6, Xm); Gadelius, Ekman and Kjellberg to the import control authority of Manchukuo and the Kantō Leased Territory, Memorandum [n.d., but written in 1938] (HP 64, Xm).

111 Ottosson, Handel under protest, 265.

112 "Importproblem i Manchukuo" [Import problems in Manchukuo], Svensk Export, 1938, 197; Tennberg to Bagge, March 23, 1938 (UDA, 2210.03.1, HP $64, \mathrm{Xm})$. About the Manchurian success of Gadelius, see newspaper reports in Nya Dagligt Allehanda, June 22, 1938, and March 10, 1939. 
113 Svensk Export, 1938, 59; Erich Pauer, "Deutschland-Japan: Überblick über die wirtschaftlichen Beziehungen, 1900-1945" [Germany-Japan: Overview of economic relations, 1900-1945] in Japan und Deutschland im 20. Jahrbundert [Japan and Germany in the 20th century], ed. Klaus Kracht, Bruno Lewin, and Klaus Müller (Wiesbaden: Harrassowitz, 1984), 130-131.

114 Thomas W. Burkman, Japan and the League of Nations: Empire and World Order, 1914-1938 (Honolulu: University of Hawai'i Press, 2008), 209.

115 Statistiska Centralbyrån, Statistisk årsbok för Sverige [Statistical Yearbook of Sweden], 1939.

116 Ottosson, Handel under protest, 259-264.

117 See: Bagge to UD, Telegrams, after July 1937 (BA, 230033.2, E2, I). 


\section{Staying relevant Total war in Europe}

\section{International politics}

\section{Sweden and Japan: outside the European war but inside the global turmoil}

Before resigning in August 1939, Japanese Prime Minister Hiranuma Kiichirō famously characterized the world as fukuzatsu kaiki-complicated and inscrutable. It was an appropriate description of the years before Pearl Harbor. For instance, until the end of Hiranuma's eight months' stint at the helm of the Japanese Government, some Swedish observers still hoped for a renewed Japanese-British alliance, as during World War I. They were bitterly disappointed when a standoff between the two Empires in the Chinese coastal city of Tientsin made it clear that Britain and Japan had ended up on opposite ends of a Great Power conflict. ${ }^{1}$ By that time, tensions had already risen to the boiling point in Europe, where Danzig had become the focus of a new crisis involving Germany, Poland, Britain, and France. On September 1, 1939, Hitler attacked Poland. As a result, London and Paris declared war on Berlin. The position of Japan in this constellation was unclear. On the one hand, Germany and Japan were signatories of the Anti-Comintern Pact, but that was, above all, an alliance against the Soviet Union, not against Britain or France. On top of that came a stinging betrayal from the perspective of Tokyo, because Hitler had reached an agreement with Stalin on August 23, right before the attack on Poland. The infamous MolotovRibbentrop Non-Aggression Pact reversed everything Japan assumed its fascist ally in Europe was standing for. Germany's realignment with the sworn enemy, which Japan was fighting unofficially in Nomonhan (Khalkhin-Gol), created an unfavorable power constellation in Asia that deeply alienated Japan, leading to a significant rethinking of its foreign policy.

Furthermore, with its warfare in China, Japan antagonized not only Britain and the USSR but the United States, too. At first, the United States maintained regular commercial relations but in mid-1938 Washington began with a "moral embargo" on the export of implements of war to Japan and on July 26, 1939, Secretary of State Cordell Hull notified the Japanese ambassador that the United States would terminate the 1911 Treaty of Commerce and Navigation. ${ }^{2}$ The decision came into effect six months later, which laid the groundwork for US

DOI: $10.4324 / 9781003182061-5$ 
legal embargoes that culminated in a freeze of Japanese assets and an oil embargo on August 1, 1941. Toward the Chinese side, Roosevelt used Japan's euphemism of a Chinese "incident," since this allowed him, conveniently, not to apply the neutrality laws that Congress had been creating since 1935. Most importantly, it meant that the cash-and-carry clauses of the neutrality acts would not apply, and that the United States could maintain normal trade with China. Nevertheless, the disdain of the US public toward arms trade, after the publication of H.C. Engelbrecht and F.C. Hanighen's bestseller Merchants of Death (1934), and the subsequent work of the Nye Committee, which exposed the large gains of the armament industry, put political taps on the Roosevelt administration in terms of supporting China with weapons. Whereas, from 1933 to 1935 the United States had sent 339 planes to Chiang Kai-shek's nationalists, the number dropped to zero in the first two years of the Sino-Japanese War. Only when the United States and Japan became outright enemies, in 1941, US weapons exports to China increased again significantly. ${ }^{3}$ Lucky for Chiang, there were other options. The most important support came from Hitler and Stalin. Since ties with Germany dated back to the Weimar Republic, China was still able to obtain an agreement in April 1936 that provided it with 60 percent of its arms imports, in return for its wolfram and some other ores. Only some months after all-out warfare with Japan started, Hitler chose to end his support for Chiang. Thereafter, it was Stalin who, until 1941, filled the void by providing planes $(1,235)$, artillery $(1,600)$, machine guns $(14,000)$, rifles $(50,000)$, as well as thousands of specialists like military advisors, pilots, and engineers to sustain Chiang's resistance. ${ }^{4}$

In Europe, too, the situation became inscrutable. Right after the attack on Poland, Stockholm declared its neutrality. In a much-publicized statement, Premier Per Albin Hansson assured that Sweden's defense was well-prepared, which was a very optimistic assessment of the actual situation. Similar to the belligerency in China, during the first months of war in Europe, many Swedes thought of themselves as detached observers of a Great Power conflict that did not concern them much - a feeling that would not last for long. On November 30, 1939, the Soviet Union attacked Finland, which started the Winter War (November 30, 1939-March 13, 1940). To most Swedes, this was entirely different from China or Poland. There was a strong opinion in favor of assisting the Finns, but the government was divided. Whereas Foreign Minister Rickard Sandler wanted active intervention, many of his colleagues were in favor of a more cautious policy. On December 12, the government resigned and was replaced by a national coalition made of all parliamentary parties, save the Communists. Per Albin Hansson continued as prime minister, but the post of foreign minister was taken over by a nonpolitical career diplomat, Christian Günther, who had previously (1934-37) served as state secretary at the UD—one of the highest-ranking civil positions at the ministry - and later as envoy to Norway. To the disappointment of the Finns, Sweden did not intervene. However, in contrast to the other theaters of war, Stockholm allowed not only exports of arms and ammunition to its Nordic neighbor, but also volunteer troops to go East. This was also the only conflict in which Stockholm never declared neutrality but made it known that 
it was "non-belligerent," a status that had not been defined under international law and in many cases (like Italy) was a first step toward entering the war at a later stage. ${ }^{5}$

The Winter War ended in March 1940, but the situation in Northern Europe became even more dramatic when the German Reich invaded and occupied Denmark and Norway the following month. A result thereof was the so-called "Skagerrak Barrage," a German-made minefield on the ocean, between the Norwegian Kristiansand and the Danish Hanstholm-the gateway from the North Sea to the Baltic Sea. That cut the Swedish merchant fleet in two almost equal parts: one on each side of the dangerous barrier. From then on Swedish ships would sometimes be given safe conduct through this military obstruction, after permission from both, German and British authorities, but foreign trade was severely hampered. Many of the ships that had remained on the oceans (43 percent of the Swedish tonnage) had to be leased to the Allied Powers, while the domestic economy became heavily dependent on continental commerce. Until 1944, Germany and German-controlled areas accounted for 85 percent of the Swedish foreign trade. In exchange for iron ore from Lapland the Germans would provide coal and fertilizers. ${ }^{6}$

The situation for Stockholm intensified further in June 1940, when France surrendered, and the Soviet Union absorbed the three Baltic States. It did not take much imagination to realize that Sweden's independence, too, was in danger. An unmistakable sign of that was an increase in German pressure to allow transfers of its soldiers from occupied Norway back home through Swedish territory. After only short negotiations, Hansson's government saw no other alternative than granting permission. Officially, the soldiers were on leave and they had to pay for the transport on the Swedish State Railways, but the act was a clear breach of the laws of neutrality. ${ }^{7}$ An even more serious episode in this respect occurred after Germany invaded the Soviet Union, in summer 1941. Berlin now started demanding that Sweden allow the transit of one of its army divisions (Engelbrecht division) from Norway to the battlefield, threatening that a rejection of the request would be interpreted as an "unfriendly act." The ultimatum triggered intense discussion within the coalition government where one faction vehemently rejected further concessions and others, including Prime Minister Hansson, were more inclined to accept the request. At this point, King Gustaf $\mathrm{V}$ actively influenced the discussion by threatening to abdicate if the German demands were not met. At least this was how the prime minister interpreted the King's declaration afterwards. In the end, the government allowed the transit. ${ }^{8}$ At the same time, the German (and Finnish) invasion of Soviet Russia was greeted with certain enthusiasm in military circles that harbored sympathies for Germany (as well as for Japan). They were expressed by the Commander-in-Chief, General Olof Thörnell. ${ }^{9}$ Overall, public opinion was divided between pro-Axis, pro-Allied, and "neutralist" perspectives. ${ }^{10}$ Many predicted a victory for the Axis, which led to increased self-censorship in the public sphere. Even debates in the parliament became more timid than usual. Only some newspapers like Göteborgs Handelsoch Sjöfartstidning remained outspoken. Despite various personal appeals-even 
from King Gustaf V-this newspaper continued its rhetorical attacks on the Reich and the National Socialist regime. The German legation, showing little regard for Swedish freedom of the press, protested vociferously, which convinced Minister of Justice, K.G. Westman, to prohibit the distribution of the paper over "national security concerns."11

\section{Less friction in bilateral relations}

Paradoxically, the tense international situation led to a calmer moment in Swedish-Japanese bilateral relations. Ever since the Mukden Incident, the two countries had been locked in an uneasy relationship defined by mutual suspicion. Diplomatically, in Geneva, they had walked separate ways, while trade continued and even flourished. This schizophrenia continued well into 1939. For instance, when the news about the termination of the US-Japanese trade treaty reached Stockholm, media reports were enthusiastic, interpreting the action as a form of punishment of Japan. The Social-Demokraten viewed the step as the beginning of the long-awaited sanctions against an aggressor state-something that would not come true in a meaningful sense until two years later. ${ }^{12}$ Those views were certainly popular. As we have seen in the previous chapter, only die-hard economic liberalists, ultra-right wingers, and occasional anti-colonialists would still maintain that Japan was not to blame for the warfare in China. At the same time, however, nobody in Sweden demanded that their government abolished its own treaty with Japan. Newspapers had fallen silent on Sweden's interactions with the Empire. In fact, at the dawn of the European war, diplomacy with Japan, if anything, seemed to improve again. Stockholm even received another goodwill visit from Fujiwara Ginjirō, who constructed a garden for the Japanese teahouse in Stockholm. He met with Prime Minister Hansson and was granted an audience with King Gustav V. Moreover, Fujiwara's visit was surrounded by positive publicity in the Swedish press. When a new Japanese envoy, Matsushima Shikao, arrived in late 1939, his task to foster friendly relations was not hopeless, despite the tense international situation. He hinted that the hostilities in East Asia were generating certain frictions but still summarized Swedish-Japanese relations as "exceedingly good." 13 After all, Sweden's attitude had become-if not more amicable - at least less confrontational toward Japan. Of course, there were no illusions about the injustice of the situation. Bernhard Karlgren, a sinologist and great connoisseur of East Asian affairs, summed up the Swedish assessment about Asia in a booklet on "Japan's path and goal" (published in 1940). Manchukuo was obviously still a satellite of the Empire and Japan's actions in China were not only illegal but a severe military miscalculation, Karlgren wrote. ${ }^{14}$

Nevertheless, Stockholm grudgingly accepted that "might could make right." The protest movement of 1938 and the unsuccessful calls for a boycott were merely the last signs of civil society's moral conscience that rejected the use of violence against civilians. But the ferocity with which Swedish diplomats used to oppose Japanese actions in Manchukuo during the League of Nations sessions of 1932-1933 had given way to resignation about the effectiveness of the use of 


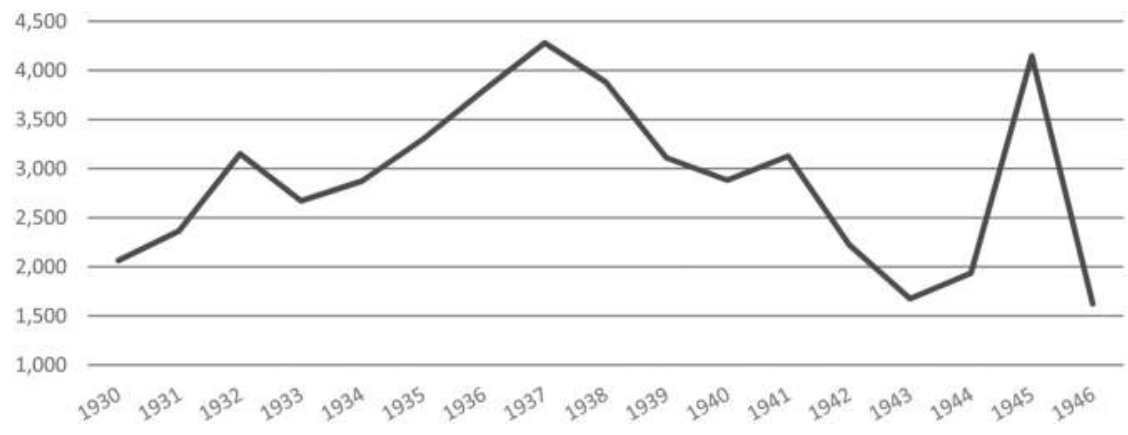

Figure 5.1 Number of times Japan is mentioned in major Swedish newspapers 1930-1946. Source: Data obtained by searching the database "Svenska Dagstidningar" [Swedish Newspapers] at the Royal Library of Sweden Stockholm, for the period 1930-1946.

force-something that only a few years earlier had supposedly been "outlawed" through the Covenant of the League and the Kellogg-Briand Pact. The once enthusiastic supporters of collective security had evidently lost the debate. Almost everyone in Sweden (except for Carl Lindhagen) had to admit that national defense must be given priority. That was true for the government and the media landscape. At the same time, Japan's warfare in China barely still made headlines. In fact, Japan as a topic, was fading from Swedish newspapers, starting from 1937 - a trend only broken by the beginning and the end of the Pacific War. ${ }^{15}$

As Swedish support for the League of Nations faded away, its public and private condemnation of Japanese actions rescinded, resolving the schizophrenia in favor of normal relations with Japan. There are some indications that Japanese statesmen tried to assuage Swedish perception through public diplomacy like the gifting of the teahouse and its garden, but all in all, the shift in national attention had little to do with Japanese actions. Rather, it was the logical outcome of a rapid change in the international environment, which reshaped Swedish public debate and foreign policy. With the League system mortally ill, the country returned to its traditional neutrality policy, which also gradually "tamed the Swedish hound" from the Japanese perspective. To understand this shift, we need to go back to the moment when Swedish foreign policy strategy changed from collective security to neutrality.

\section{National politics}

\section{The return of Swedish "strict" neutrality}

Although Sweden's "traditional neutrality" went back to the eighteenth and nineteenth centuries and to World War I, its neutrality was not anchored in international law in the same way as those of other European neutrals. The permanent 
neutralities of Belgium, Liechtenstein, and Switzerland were codified by treaty agreements. For them, it would have been "illegal" to join an alliance. For Sweden, that was different. Not even domestically there were arrangements that compelled the government to remain neutral in the wars of others. Neither the Constitution nor legislative acts existed to that extent. For Sweden, neutrality was purely a matter of foreign policy. Albeit, by the 1920s, it had long gained cultural importance and become a source of identity. ${ }^{16}$ That might explain why Sweden's departure from neutrality for the sake of the League's collective security approach had been more of a slow and silent good-bye than an outright rejection of previous principles. Parliament and government never declared that their neutral tradition was to be replaced by a different foreign policy doctrine. Rather, neutrality was phased out quietly as Sweden transitioned into a stakeholder of the League system. This is best illustrated by comparison to Switzerland which, as a prerequisite to join the League, had demanded-and received - written guarantees that it would be allowed to continue its policy of permanent neutrality. ${ }^{17}$ The unspoken phasing out of Swedish neutrality is also underscored by the silence that fell over the topic. There had not been any substantial discussions in parliament on neutrality for 15 years. Only the developments in Abyssinia made a reconsideration unavoidable.

The question whether neutrality should again become a pillar of Swedish foreign policy was intimately tied to the success of the League. In this context, there never was a real consensus among or within political parties on the role of the League. From the beginning, there was a divide between an "idealist" school of thought which believed in the value of collective security, international disarmament, and sanctions, and a "realist" school, which considered such a security as neither attainable nor desirable. The Social Democrats and the left wing of the Liberal Party were the major political forces behind the first approach, while the latter was chiefly the viewpoint of the Conservatives and the Farmers' League. ${ }^{18}$ The conservatives found themselves in a minority position during most of the interwar period. Hence, Sweden's international policy had mostly been shaped by politicians who pursued close adherence to the League's idealistic goals. However, the brutalization of the League's principles by Japan (1931) and Italy (1936), as well as the tepid reactions of other Great Powers, led to a deep disappointment among that group. After all, the energetic engagement of Swedish diplomats in Geneva for binding mechanisms and even interventions against aggressor states had been fueled by the belief that small states would be among the primary beneficiaries of the League's collective security mechanism. During World War I, small neutrals had been among the first countries that were dragged into the fight. Great Powers considered the laws of neutrality as secondary to the immediate necessities of their belligerent enterprises. Especially the experiences of Belgium and Luxemburg, whose internationally guaranteed neutral rights had immediately fallen prey to German war tactics, had had a chilling effect even on those neutrals who survived the war unharmed. As a direct result, Europe's staunchest neutrals - Sweden and Switzerland-joined the League of Nations as founding members in 1920. This had potentially far-reaching consequences for 
their neutralities, as the Covenant of the League required an extremely strong commitment to a global alliance of states that would defend each other through sanctions and even by military means. Article XVI of the Covenant unequivocally enshrined the "one for all, and all for one" principle into a binding international security treaty. ${ }^{19}$ However, 15 years later, European small states had to learn painfully that the promises of collective security were much harder to enforce in reality than the letter of the law had made it seem. No sanctions had been levied against Japan, and only insufficient measures were taken against Italy, failing to deter it from its aggressions against Abyssinia. In early 1936, Swedish politics was, therefore, confronted with two interlinked questions that arose from the League's failure to secure its weaker member states. First, should Stockholm continue to adhere to League sanctions? And, second, if the League was really failing then how would Sweden take care of its security from that point onward?

An answer to both questions emerged only slowly. At first, no party in the Riksdag debates of early 1936 seriously questioned Swedish adherence to League sanctions, except for the tiny Socialist Party. Social Democrats like Rickard Sandler and Östen Undén, as well as the leader of the Conservative Party, Gösta Bagge, initially supported continuous adherence to the sanctions against Italy. A rupture with the League and Sweden breaking its word internationally was out of the question. ${ }^{20}$ Especially Sandler and Undén tried to convince their colleagues that the failure of the League was anything but certain. A reform of the League for more effectiveness was what Sweden should be striving for, not a disengagement from it and certainly not fatalism about its future.

This line of argument slowly collapsed the more successful Italy became in its ruthless conquest of Abyssinia and the less the Great Powers seemed willing to enforce the Covenant, as exemplified by the Hoare-Laval Plan. Most significantly, the Social Democrats gradually changed their standpoint, with a noticeable turn toward less international activism. Some of them had accepted that the "hungry" states had legitimate claims and should be appeased. By this, their views were not unlike those of British Prime Minister Neville Chamberlain. They distanced themselves from Versailles and, indirectly, from Geneva. Another group of Social Democrats started arguing more cautiously that even if Sweden went back to a neutral foreign policy, it would only be a temporary retreat from the idealist goals of the League. They hoped the League would regain its strength when the time was right, that is, when Britain and France were sufficiently armed. Finally, there was a faction that detested appeasement and thus gave in to the realist view that national self-reliance was the only possible way forward to defend Swedish interests. The remaining internationalists, as we have seen, were inspired by the anti-fascist struggle in Spain and would also join the boycott movement against Japan. In this, they had full support from the Swedish Communist Party. ${ }^{21}$

In early May 1936, Haile Selassie, the Emperor of Abyssinia, went into exile to escape Mussolini's advancing troops, which could have been a trigger for League sanctions. However, since Germany had reoccupied the Rhineland two months earlier, there was no hope that France would agree to an oil embargo on Italy. ${ }^{22}$ The impossibility of economic reprisals to help a fellow small state reverberated 
strongly in Stockholm. Gösta Bagge was the first one who, despite his previous support for sanctions, started to argue that the only reliable source of Swedish security would be one that did not depend on external forces. Instead, he wanted to strengthen Sweden's military defense and reinvigorate its nearly forgotten neutrality policy. During Sweden's parliamentary debate of May 26, 1936, Bagge exclaimed almost timidly that "with the development of the new Great Power combinations and alliances, Sweden must have the opportunity to fall back on itsyes, I say it - traditional neutrality policy in situations when this becomes inevitable." ${ }^{23}$ He was not in favor of taking Sweden out of the League-only the Socialist Party members wanted that-but the conservative leader suggested reforms that would make League membership compatible with neutrality, mainly by weakening Article XVI, and free Sweden officially from the sanctions obligations which had so miserably failed to produce any results for Abyssinia and China. ${ }^{24}$

Naturally, Foreign Minister Sandler opposed Bagge's views, arguing that a policy reversal to neutrality would entail breaking with League sanctions and doing so would mean to either negate the conflict in Abyssinia altogether or withdraw from the League-neither of which he thought was feasible. ${ }^{25}$ Undén, too, criticized the conservative leader:

It often seems to be an easy and comfortable policy to recommend our exit from the League of Nations and refer to neutrality policy and defense. But neutrality policy $(. .$.$) is not a formula that applies to all times, regardless$ of other developments. The [same] neutrality policy as carried out during the World War may not be feasible during a future war because of technical developments of war[fare] and the development of economic relations. ${ }^{26}$

However, as the spring of 1936 faded away, so did the confidence of the Social Democrats. In his closing statement, Foreign Minister Sandler subsumed the mood of the idealist school that had to come to terms with the potential failure of the League:

Although I understand that neutrality may be necessary once again, surely no one can seriously argue that neutrality can be the final goal, (...) for, gentlemen, to exercise neutrality means, in fact, that one has failed in the task of war prevention, which must be the prime goal of the statesmen, and even if that task proves to be overwhelming from time to time, it can, of course, never be abandoned. ${ }^{27}$

On June 19, the Hansson government collapsed over an unrelated issue concerning the pension system. In terms of foreign policy, that did not change much because Sandler's successor in the short-lived (three months) government of the Farmers' League, K.G. Westman, was of similar views as the conservatives. He believed that "as long as Sweden remains in the League of Nations, our country should consider the policy of neutrality in its old sense and its old content as the basis for its foreign policy and its relationship with the League of Nations as a, let's say, functionalistic 
superstructure." ${ }^{28}$ In his brief term as foreign minister, Westman was presented with the first chance for Sweden to seriously voice its dilemma and reservations internationally. On July 1, a group of neutrality-inclined states-Sweden, Denmark, Finland, the Netherlands, Norway, Spain, and Switzerland-issued a joint declaration with a strong warning against any further erosion of the League's principles, arguing for the necessity of finding practical ways to handle its inefficiencies. "We do not think it right," the small states wrote, "that certain articles of the Covenant, especially the article dealing with the reduction of armaments, should remain a dead letter while other articles are enforced. (...), we feel that every effort should be made to ensure the success of the experiment represented by the foundation of the League as an attempt to establish an international society based upon law." 29 The expression of hope for reform was accompanied by a warning that "we would place it on record that, so long as the Covenant as a whole is applied only incompletely and inconsistently, we are obliged to bear that fact in mind in connection with the application of Article 16." This was, of course, the neutrals' final way of demanding action from Great Powers or, in the absence of such, be absolved from all future demands to join sanctions or military measures by the League. However, only five days later, on July 6, the Coordination Committee of the League recommended to lift all sanctions against Italy and thereby, de facto, recognized Mussolini's fait accompli in East Africa. It was the opposite of what the neutrals had demanded and marked the end of their activism in Geneva.

After this failure to rescue Abyssinia, debates in the Riksdag on the future of Sweden's neutrality policy became a staple on the agenda. That included the question of Swedish volunteers in the Civil War in Spain and Sweden's position toward the League. Even after the return to power of the Social Democrats on September 28, 1936, the tune of the Swedish Government changed for good. So much so that even Rickard Sandler, who had become foreign minister again, declared on November 7, 1937, in a speech to a student association of Uppsala University that Article XVI no longer had any binding power because "a law, which does not equally apply to everyone and at all occasions, has, at present, ceased to be a law." 30 Two months later, Sweden, together with the Netherlands and Switzerland, declared officially that it did not intend to adhere to Article XVI anymore. ${ }^{31}$

The end of the decade had reversed the collective security approach of the internationalists. Although Sweden briefly tried to forge a group of like-minded Nordic neutrals who would form a block against the emerging power politics on the continent, that initiative never went beyond the planning stage. ${ }^{32}$ By the time Hitler attacked Poland, Sweden was on its own. And although much support was rendered to the Finnish side in the Winter War, Sweden remained either nonbelligerent or issued declarations of neutrality whenever new theaters of war emerged. ${ }^{33}$ The dream of collective security was over, for good.

\section{The inception of Japanese "strange" neutrality}

Japan, too, was caught in an escalating nightmare-one, however, of its own making. At home, the Empire came under pressure as popular support for the 
war started waning when the economic burden of the occupation started to bite. Parliament had to grant an extra war credit of $¥ 2.5$ billion in autumn 1937 which was a vast sum, considering that ordinary annual expenditures amounted to $¥ 2.8$ billion. To cope with the fiscal situation and the perceived need for austerity, the government banned anything that it considered "luxury" and started lauding frugality as a virtue. More people were employed in the armaments industry and a movement for spiritual mobilization was formed. In 1938, new legislation gave the government emergency powers, eliminating the remnants of political pluralism. Parliament was reduced to a rubber stamp council and the economy was put under tight state control. In order to prevent lack of currency, a licensing system was introduced for all imports. Working hours were extended and unions merged with employer associations under the name of "patriotic industry federations." In short, the war effort put an end to the liberal trends of Japanese business. Plans for an economic bloc, consisting of the Japanese Empire, Manchukuo, and China, could not compensate for this fact. Real wages and living standards began to fall and in 1939, the first energy and food shortages appeared. Inflation was on the rise and had to be counteracted with a price and wage freeze. ${ }^{34}$ At the turn of the decade, when Japan awaited its 2,600-year anniversary (on February 11, 1940 ) the country was living in a state of economic siege for which it had no one to blame but itself.

The spring of 1939 unexpectedly opened a new front in Northeast Asia. After months of border skirmish at the Manchu-Mongolian border, the Kwantung Army suddenly found itself in an all-out battle at Nomonhan with Mongolian and Soviet forces. Through a series of miscalculations, based mainly on the assumption that the Red Army was too weak to fight Japanese troops, the battles escalated to another "war in all but name." Japan kept referring to the situation euphemistically as another "incident" - but what an "incident" it was. More than 20,000 men were killed on both sides, 100,000 troops remained engaged for four months, and the affair had the potential of pushing the Soviet Union to (officially) declare war. That would have been disastrous to Tokyo for several reasons, not at least because a "real" war might have triggered the export restriction mechanisms of US neutrality laws. It did not come that far because Stalin, too, had little appetite for drawing Hitler's attention to the fact that a substantial part of his Red Army was needed in the East. Japan and the USSR therefore both downplayed the severity of the battles.

Meanwhile, Japan's armed forces were at odds about the military future of the empire. The navy had become convinced that the forward strategy for Japan should be Southeast Asia and that confrontations with Britain, France, and eventually the United States were inevitable. The army, on the other hand, had set its eyes on North Asia, to which Nomonhan had become an important test. In early 1939, politics in Tokyo still seemed to favor the army's approach, as the government was committed to fighting Bolshevism together with Germany. The AntiComintern Pact between Berlin and Tokyo had been in force since November 25,1936 , and should have provided a united German-Japanese political front against the Soviet Union. However, the agreement proved costly to Tokyo and 


\section{Staying relevant}

exceedingly empty. Not only did it lack German commitment, but it became a liability when Hitler changed his objectives. As the political fallout in Europe grew hotter, he wanted Japan to commit to his bellicose rhetoric against Britain and France, not against the USSR, and he wanted it in writing. In diplomatic circles, it was reported that during negotiations with Ambassador Ōshima Hiroshi in Berlin, Hitler had even threatened to suspend the Anti-Comintern Pact if Japan did not agree to a closer military alliance. ${ }^{35}$ But the internal and external disagreements over who the actual "enemy" of the Axis Powers was led to a paralysis in Tokyo and, eventually, to a separate German-Italian agreement, the "Pact of Steel" (March 22, 1939). In this document, Rome and Berlin pledged that if "one of them becomes involved in military complications with another Power or other Powers, the other Contracting Party will immediately step to its side as an ally and will support it with all its military might on land, at sea and in the air." ${ }^{36}$ Tokyo never joined this enforced alliance, not least because the German pressure caused more friction among the Liaison Conference (the inner circles of the cabinet). The army and the war ministers were now in favor of a closer alliance while the navy became cautious over commitments that could draw their resources into a European war. ${ }^{37}$ Thus, the paralysis in Tokyo over the right approach toward Germany remained.

A tremendous diplomatic blow to Japan followed on August 23 when, at the height of the fighting in Nomonhan, Hitler concluded a Non-Aggression Pact with the USSR. The timing was no coincidence. Stalin, who had also an offer for an alliance with Britain and France on his table, was influenced at least partially by the Japanese challenge in the Far East to choose Germany as his European bedfellow due to the latter's standing with Japan. A two-front war would have been life-threatening to the USSR, which is why Stalin explicitly demanded that Berlin used its ties with Tokyo to bring about a betterment in Japanese-Soviet relations. That quickly happened after it became clear to Japan that Soviet military forces were now free for deployment in the East. Tokyo agreed to a ceasefire, effective from September 16, 1939, a day before the Red Army marched into the eastern half of Poland. ${ }^{38}$ To Japan, the German-Soviet rapprochement was an immense betrayal of the letter and spirit of the Anti-Comintern Pact. So much so, that Japanese media questioned if friendly relations with Germany could even be continued. ${ }^{39}$ The crisis brought down the cabinet of Hiranuma Kiichirō (January 5-August 30, 1939), which was succeeded by the government of Abe Nobuyuki (August 30, 1939-January 16, 1940). In his inaugural speech, General Abe openly contemplated disavowing the pact with Germany. ${ }^{40}$ The de facto defeat at Nomonhan and the Non-Aggression Pact altered Tokyo's assessment of the Soviet Union. Not only was Stalin a more formidable military enemy than anticipated, but his diplomacy had left Japan isolated from its European allies. As a result, the Abe government could not even contemplate supporting Germany once fighting did break out in Europe. On September 5-shortly after Britain and France had declared war-Abe issued a brief statement that "in the face of the European war (...) Japan does not intend to be involved in it; she will concentrate her efforts upon the settlement of the China affair." ${ }^{41}$ A day later, the 
Gaimushō submitted a note to diplomats of the four belligerent countries as well as the US and Italy, reiterating that Japan would not interfere in the hostilities but that it also expected that all states "should refrain from creating incidents that would force Japan to abandon its policy of non-intervention." ${ }^{42}$ This was a thinly veiled threat at the address of Moscow, London, and Paris. To settle the "Chinese affair," it was essential that European and American support for the Chiang Kai-shek regime in Chungking stopped and that "incidents" like the ones in Nomonhan could be averted.

Abe's statements prudently avoided the word "neutrality." The legal impact which that might have had under international law was nothing the government was willing to imply. The Gaimushō understood the technicalities of neutrality proclamations rather well as Japan had used them in the past. ${ }^{43}$ The Gaimushō had, in fact, conducted two studies on their implications in $1939 .{ }^{44}$ It would have committed Japan to an impartial attitude (a backbone of previous Japanese neutralities) at a time when Tokyo's ties with Germany, the Soviet Union, Britain, and the United States were strained, and a maximum of policy flexibility was the cabinet's desired course of action. The example of the United States, which since 1936 had enacted four neutrality laws that prohibited trade in war materials with belligerent countries, was a model that Japan did not want to follow. Besides, President Roosevelt, on September 3, had just declared that the United States would maintain "true neutrality." 45 For the sake of the remaining Axis collaboration, Tokyo could not be seen as following the US example. From the standpoint of international law, that was not even necessary. To enjoy the rights of a neutral power, a declaration of neutrality was not a precondition. The absence of a state of war automatically made the relevant laws applicable-which was a detail that contemporary observers did not miss. ${ }^{46}$ Not to declare "strict neutrality" (like the United States or Sweden) nor acting as Germany's ally was, therefore, Japan's best choice at the moment because it left all options open under the "noninvolvement" policy. For nearly two years, the government and national media did not grow tired of reiterating Japan's dual foreign policy goals of "noninvolvement" in Europe and "primacy" in Asia.

The outcome of these developments was that by the end of September 1939, the fault lines of a new international system of the European war emerged. Some countries were fighting, others were not, but no nation remained untouched. Small neutrals had to fear an attack by either side and larger neutrals (like Italy, Spain, the USSR, and the United States) were courted to join the fighting on "their" ideological side. In fact, for the first two years, Sweden and Japan found themselves in somewhat similar positions: suspicious but friendly toward Germany, latently threatened by the USSR, and, most importantly, not at war. Despite the differences in their international goals and military postures, Sweden and Japan both ended up on the "neutral end" of the European war. Even the Tripartite Pact (September 27, 1940) did not fundamentally alter the situation. The treaty created a defensive alliance between Rome, Berlin, and Tokyo, but was to Japan more of an instrument to deter the United States rather than an alliance counteracting Britain or France. The pact did not draw Japan into the European 
war either because it demanded military assistance only in case of an attack on one of the treaty partners but not in case of an offensive campaign (which Hitler and Mussolini continuously did). Interestingly, the Swedish press was rather realistic about the meaning of the pact, concluding that it was probably neither impactful nor long-lasting. Most newspapers, in fact, were more surprised at Tokyo "joining" the Axis Powers whom they still considered to be only Rome and Berlin. ${ }^{47}$

In 1940, Japan's cabinet was reshuffled twice. On January 16, Abe handed the premiership to a navy man, Admiral Yonai Mitsumasa, who, like Hiranuma Kiichirō, could not hold himself at the helm of the government for long. His tenure ended on July 21 over the opposition of the military to his pro-AngloAmerican and anti-German politics. When his Army Minister, Hata Shunroku, resigned and no army general was willing to replace him, Yonai was forced to resign because the constitution required active-duty members from the army and navy in the cabinet (effectively giving both institutions veto power over the executive). A civilian government was born the next day under the well-respected but indecisive Konoe Fumimaro. ${ }^{48}$ Konoe had been a relatively moderate prime minister from 1937 to 1939 , but his reappointment did not herald a return to a conciliatory foreign policy. Not only was he involved in the founding of the Taisei Yokusankai (the Imperial Rule Preservation Association)-a party to replace all parties - he also continued a close relationship with the military and appointed nobody less than Matsuoka Yōsuke to serve as foreign minister. Matsuoka was the man who had delivered strident attacks against the Chinese position at Geneva and who ultimately took Japan out of the League in 1933, the diplomat whom Japanese media had praised for "hurdling" around those pesky small states. He reversed the course of the Yonai cabinet and started working toward a closer alliance with Germany. One of his first measures was a very visible purge in the Gaimushō. The Swedish minister to Tokyo reported that "shortly after he took office, Foreign Minister Matsuoka had no less than five ambassadors, nineteen ministers and eleven consul-generals replaced by men who were judged more apt to follow the new signals. Also in the domestic administration, officials with English- and American-friendly attitudes have been replaced in a number of cases with new staff." ${ }^{49}$ It was under Matsuoka's tenure that the navy finally abandoned its opposition to a military alliance with Hitler, giving Matsuoka the green light to negotiate the Tripartite Pact. ${ }^{50}$ However, a more impressive stunt-and bearing greater importance to Swedish-Japanese relations-was his surprise success in negotiating a neutrality pact with the Soviet Union. Signed by Matsuoka and Stalin in Moscow on April 13, 1941, the pact aimed at imitating the GermanSoviet Non-Aggression Pact and, from the Japanese side, was believed to be a step toward a Berlin-Rome-Moscow-Tokyo axis. ${ }^{51}$ Not only did the Neutrality Pact markedly improve the political climate between Japan and the USSR, opening the way for a shipping and payment agreement, but it also freed up Japanese troops for redeployment in China. To Matsuoka's dismay, however, the liaison conference decided against increasing military pressure on Chiang Kai-shek. Instead, it opted for opening a new front in Indochina, even at the risk of provoking war with Britain and the United States. ${ }^{52}$ This navy-led expansion into Southeast 
Asia was not born under a lucky star, as Hitler again proved to be an unreliable and unpredictable ally. On June 22, he invaded the Soviet Union, breaking the Non-Aggression Pact-to the utter surprise of the dumbfounded Matsuoka. It was another frontal blow by the European ally to the cabinet's military strategy that inversed all calculations on the Japanese side. With the whole idea of a Pan-Eurasian Axis shattered, Matsuoka now shifted to support the army's view that his Neutrality Pact should be abandoned, and the opportunity seized for an attack on the Soviet Union. This time Konoe did not agree, ${ }^{53}$ and some politicians in Kasumigaseki even argued that it was the Tripartite Pact that should be abolished, not the Neutrality Pact. ${ }^{54}$ Again, neither action was taken, and the Empire continued its uneasy partnership with the Reich while also maintaining the neutrality policy toward the Soviet Union.

Despite Matsuoka almost sabotaging his own treaty with Stalin, the Neutrality Pact proved surprisingly stable. Designed to be renewable and last a minimum of five years it was broken only on August 9, 1945 (the day the second atomic bomb obliterated Nagasaki), when the Soviet Union entered the Allied war against Japan. In effect, this meant that between December 1941 and August 1945, Japan and the Soviet Union were simultaneously neutral toward each other, while fighting their respective allies at the other end of the conflict. ${ }^{55}$ The Swiss envoy to Japan, Camille Gorgé, called this in his memoirs "the strangest neutrality one has ever seen"56 - an expression which, unsurprisingly, became popular among historians as well. ${ }^{57}$ For Swedish-Japanese relations the Neutrality Pact had its own significance. It meant that a land corridor connected their trade for as long as Stockholm could be reached through the Baltic Sea. That was a not unimportant detail when considering that for the next five years, Sweden's two main interests concerning Japan — trade and diplomacy — would both rely on accessibility.

\section{Diplomacy}

\section{From multilateralism to bilateralism}

To formulate a new foreign policy (and diplomacy) after the collapse of the League system, the Swedish Government had to balance the opposing wishes of the country's loudest pressure groups. On the one hand, the export industry claimed to represent prosperity and welfare by offering employment for Swedish workers and wanted as much economic engagement as possible with all actors inside and outside of Europe. On the other hand, leftist groups prioritized ideology and kept demanding distance from law-breaking states. Unlike in the early 1930s, the latter did not gain the upper hand this time. Internationalism and collective security were now associated with serious risks. Even stalwarts like Östen Undén began to accept the inevitable; the necessity for a new security strategy and a reformulation of Swedish diplomacy. Early in 1938, he received the unenviable task of clarifying the Swedish standpoint in Geneva where a committee for the reform of the League was in session. He reminded the members that economic sanctions were supposed to be mandatory and automatic in cases 
when the League had condemned aggression. But no nation had taken any action despite the resolutions adopted in autumn 1937. The sanctions system, he concluded, was "de facto suspended." ${ }^{58}$ His address was an implicit accusation of the Great Powers that they had not lived up to their responsibilities, although that also became a boomerang since, as everyone knew, the Swedish Government had been anything but active in Brussels (see previous chapter). Instead, Sandler began seeking a regional solution to the security problem. In April 1938, he announced that Sweden would be considering security in a Nordic framework. ${ }^{59}$

The reformulation of Sweden's security strategy away from the League and toward neutrality was, of course, highly problematic as it was neither clear nor desired and burdened by the past. To maintain at least a thin veil of policy consistency, its diplomats had to mask the new approach creatively. An example was Sweden's position toward the League's condemnation of Japan after the Brussels conference. On the one hand, the UD desired not to take sides, while, on the other hand, it had previously committed itself to solidarity with the conference declaration. In addition, since fall 1936, Sweden had been a nonpermanent member of the League Council, which gave more weight to its voice. Therefore, it had to pay lip service to the League's position. On top of that, as late as January 1938, the UD circulated instructions to its diplomats that the Swedish position on Japan and China remained unchanged. ${ }^{60}$ It continued viewing Japan as being at fault, which meant that its diplomats could not officially claim a form of "political neutrality" in the affair. But any further alienation of Japan was also not desired. This required serious diplomatic juggling. For example, when Japan's envoy to Sweden, Kuriyama Shigeru, during a conversation with the acting foreign minister, K.G. Westman, pleaded for Swedish neutrality in the League, Kuriyama received an unexpected reply. Westman pointed out that since the situation in China was merely an "incident" (which was the Japanese position) and because neutrality was a status that only applied during war, the question of Swedish neutrality, in this case, was irrelevant. ${ }^{61}$ It was a position that Kuriyama could not possibly reject but that relegated Swedish policy to a legalistic technicality. It must have left a shallow taste on Westman's tongue.

The weakness of the League became even more evident at the annual assembly in autumn 1938, when more rift came to the fore. Sweden and several other states explained their lack of confidence in the sanctions system just to be met with a critique about "defeatism" by Foreign Minister Maksim Litvinov of the USSR. Sandler for his part did not want to give support to the Chinese view of the situation. ${ }^{62}$ A sudden and unexpected League decision, on September 30, to demand sanctions against Japan was not heeded by any member. It is doubtful if the decision was even discussed at the UD in Stockholm. In May 1939, the Chinese envoy informed Sandler that China was going to demand the formation of a committee for the coordination of sanctions. But the UD replied that the preconditions for such cooperation were absent and that Sweden would not back the proposal. ${ }^{63}$ At the end of July, the Chinese Foreign Ministry sent a request to Sweden and other members of the League Council. It asked for an investigation of the Japanese aerial raids against civilian targets, which showed that nothing 
had happened since the resolution of autumn $1937 .{ }^{64}$ The situation would not change for China as the question was still under discussion when Hitler attacked Poland, which marked the end of the League's work dealing with the Far Eastern conflict. No more deliberations were possible after the war in Europe started.

In December 1939, the League of Nations expelled the Soviet Union because of its attack on Finland after which the League was never convoked again until its dissolution in $1946 .{ }^{65}$ The collapse of the League and the rejection of Sweden's proposal for a Nordic neutral bloc meant that Stockholm's diplomacy became inherently bilateral, since there was simply no multilateral forum left. It is worth noting, however, that the trend toward more bilateral diplomacy in Asia had already started earlier, the outbreak of the war in Europe merely marked the endpoint of that dynamic. For example, while Envoy J.E.E. Hultman was side-accredited to the Republic of China (meaning that he was also serving as Sweden's envoy to Nanking) the increasingly complex situation led Stockholm to diversify its diplomacy by appointing two separate successors, in late 1936. Johan Beck-Friis was sent to Shanghai, which was soon to be occupied by Japan, while Widar Bagge became the envoy to Tokyo. After September 1939, nearly all of Sweden's diplomacy vis-à-vis Japan became bilateral, with only few exceptions of inter-neutral collaboration. ${ }^{66}$ As an effect of this "bilateralization," Swedish diplomats in Tokyo gained in importance as front-line observers and negotiators. We should, therefore, pause for a moment to consider what the Swedish mission looked like and how it was organized.

\section{A new minister}

The head of the Swedish legation during the height of the war years was Widar Bagge. Born on April 30, 1886, he, like his predecessor Hultman, was a career diplomat who had been going through the required stages at the UD to become a senior diplomat, starting with the position of attaché, in 1919. His first postings abroad in junior positions were to Helsinki (1921-1922), followed by London, Brussels, and Rome (all in 1922). After that, he was sent back to Helsinki (1924) where he reached the rank of first secretary in 1925. He was then sent for the first time to Tokyo in 1928, where he started working as first secretary on May 24. The year of his arrival was also the time when the legation's head changed from Ewerlöf to Hultman. Bagge, therefore, worked for three years under the man whose position he would ultimately inherit nearly a decade later. His work in Tokyo was only interrupted by a short posting to Shanghai as consul general (May 23-September 1, 1930). He returned to Stockholm in early 1931, where he became the head of the trade division. He worked there for three years with two short postings abroad, one as chargé d'affaires in Warsaw (June-November 1934) and as counselor to the legation in Paris (September 1934). Bagge returned to Tokyo in January 1937, to assume the new position as envoy extraordinary and minister plenipotentiary, which made him Sweden's most senior diplomat in East Asia. He would hold that position until his departure on April 13, 1945, before the end of the war. Officially, he was the head of the Swedish legation until 
September 1945, although at that time the chargé d'affaires at the legation, Erik von Sydow, was Sweden's most senior diplomat in Japan. Bagge's last posting before retiring from the foreign service was that of envoy to Cairo (1945-1951), after which he worked as a representative for the Swedish multinational Atlas Copco (until the age of 80) and finally moved to Paris where he died in $1970 .{ }^{67}$

Bagge was, in many ways, an untypical diplomat. He was not married and never had children. While many World War II diplomats and statesmen kept diaries or later wrote memoirs about their experiences, Bagge did not create such private records - or if he did, they did not survive. ${ }^{68}$ Only the reports, telegrams, and letters he wrote in his official capacity are available today to reconstruct his experiences in wartime Japan. It also seems that he did not enjoy the limelight very much. Even pictures of him are rare. The following two photographs were discovered only after extensive research in Swedish newspaper archives. ${ }^{69}$

Little is known about Bagge's personal life. Although he was not a socialite in private, professionally he was not badly connected among his diplomat colleagues and his Japanese hosts. ${ }^{70}$ Sir Robert Craigie, the British ambassador, mentioned him as one of the few foreign members of the prestigious Fujizawara club house (a golf club), a place "where one could meet and play with Japanese political leaders and other prominent Japanese without seeming to arouse the suspicions of the security police. (...). Amongst the most assiduous visitors to Fujizawara was Prince Konoe, who plays an excellent and steady game of golf $(\ldots) .{ }^{\text {"71 }}$ Those were certainly the moments when Bagge tied friendships with Japanese politicians. His connection with Prince Konoe, for example, would prove influential in later years. ${ }^{72}$ Bagge was known among the Japanese elite as a friend to Japan and Japanese sources describe

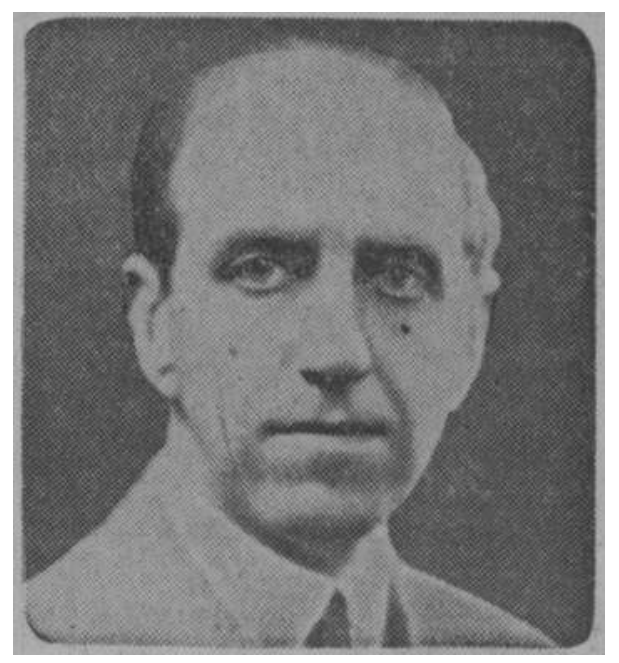

Picture 5.1 Widar Bagge in 1936. Source: Svenska Dagbladet, "Widar Bagge blir minister i Japan" [Widar Bagge becomes minister to Japan], November 28, 1936. 


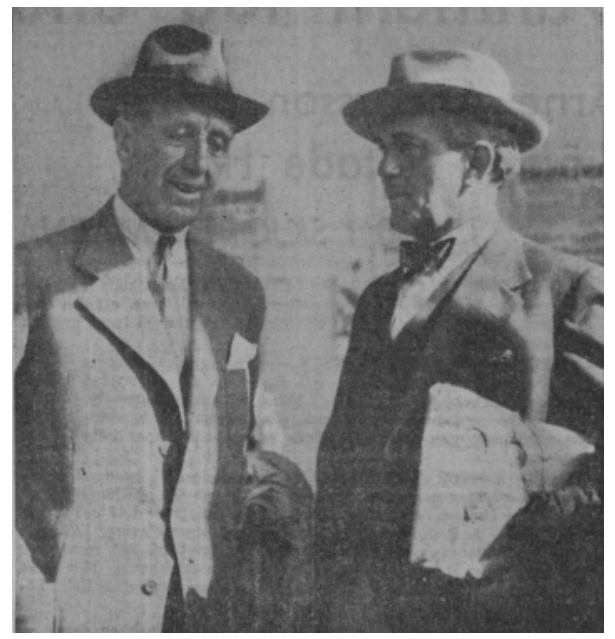

Picture 5.2 Widar Bagge in 1945. Source: Svenska Dagbladet, "Minister med Parisplanet" [Minister arriving with the Paris plane], July 14, 1945. Note: With Joen Lagerberg, Swedish minister to Italy.

him as a Japanophile. Shigemitsu Mamoru, for example, in his memoirs shows not only appreciation for Bagge's long service in Japan but describes him as someone who "knew Japan well and had a high reputation for sincerity."

A few more descriptions about Bagge are recorded in the diary of Camille Gorgé, the Swiss minister to Japan. With all due diplomatic nicety about a colleague of equal rank, Gorgé noted that Bagge "enjoys sailing on his flat boat, the type that is required here for regattas. If you visit him at his place, he looks more like a natural science professor than an athlete. You wouldn't think much of his musculature. But don't trust that impression! Outdoors, on the shores of the lake, he has the light-hearted ease of a young sailor. To untie a rope entangled by the wind, I saw him jump around on the boat like a gymnast." ${ }^{74}$ In another instance, Gorgé described Bagge as rather fearless in the face of threats. On December 16, 1944, when an earthquake shook the legation while the Swiss were dining with guests "everybody hurriedly stood up, fearing that parts of the ceiling might fall on their heads, except for Mr. Bagge, the Swedish minister, who remained immovable on his place." "75 However, one observation about Gorgé's recollection of Bagge deserves to be pointed out, which is that Bagge figured relatively little in the Swiss minister's diary when compared to other diplomats. Despite the fact that in the last years of the war the Swedish legation became the only other neutral mission to represent Allied interests in Japan alongside Switzerland and that the two mission heads collaborated frequently on issues that concerned them both, there is an ominous lack of description about these moments in Gorgé's personal diary of over 500 pages. Nor did the Swiss diplomat ever mention Bagge in the same cordial tone that he used, for example, to refer to the (other neutral) 


\section{Staying relevant}

Spanish minister, Santiago Mendez de Vigo y Mendez de Vigo, whom Gorgé constantly refers to as "my dear friend." No such bonds seem to have existed between Gorgé and Bagge. It is likely that the Swede kept a professional distance to his peers in the diplomatic corps.

\section{The Swedish mission}

The Swedish legation was small and constrained in its resources when Bagge arrived in early 1937. He only had one legation secretary at his disposal and one chancellor to take care of an equally small Swedish community of around 100 people. ${ }^{76}$ On the other hand, the legation was supported by a relatively large consular network. No less than five honorary consulates were operating in the Japanese Empire. A comparison with two other wartime neutrals illustrates how large this was: Switzerland operated not a single consulate in Japan at the time and Spain operated only one. ${ }^{77}$ Sweden, in contrast, had hired four honorary consuls on the Japanese mainland and one in Dairen, on the Kwantung Leased Territory. The personnel position of the Swedish mission in 1937 is illustrated in Table 5.1. ${ }^{78}$

The consulates were designated as "honorary" because they were not staffed with career diplomats from the UD, but with businessmen who were named consuls and furnished with the necessary insignia of the Swedish state to fulfill clerical work, mainly the facilitation of trade. Some honorary consuls were not even Swedish citizens. Frederik Ringer, in Nagasaki was a British national. Born in Japan, he was a merchant who served also as the Norwegian consul, all while being the general manager (and one of the owners) of the trading company Holme, Ringer \& Co. Similarly, Ernest William James in Kobe was also a British citizen, endowed with a large fortune (Picture 5.3). ${ }^{80}$

The consul in Yokohama, Gösta Guston, on the other hand, was a Swedish national and, as we have seen in the previous chapter, an outspoken personality

Table 5.1 Personnel of the Swedish mission to Japan in 1937

\begin{tabular}{|c|c|}
\hline \multicolumn{2}{|l|}{ Diplomatic Personnel } \\
\hline Minister Plenipotentiary & Widar Bagge \\
\hline First Secretary & Tor H. W. Wistrand \\
\hline Legation Chancellor & Johan J.W. Hjortzberg-Nordlund ${ }^{79}$ \\
\hline Honorary Positions & \\
\hline Honorary Consul Kobe & Ernest W. James \\
\hline Honorary Consul Yokohama & Gösta B.T. Guston \\
\hline Honorary Consul Dairen & Walter H. Winning \\
\hline $\begin{array}{l}\text { Honorary Vice Consul } \\
\text { Nagasaki }\end{array}$ & Frederik E.E. Ringer \\
\hline $\begin{array}{l}\text { Honorary Vice Consul } \\
\text { Shimonoseki }\end{array}$ & William H. Sainton \\
\hline
\end{tabular}

Note: At the beginning of Bagge's term.

Source: Sweden. Utrikesdepartementet. Kungl. utrikesdepartementets kalender, 1938, 70 . 


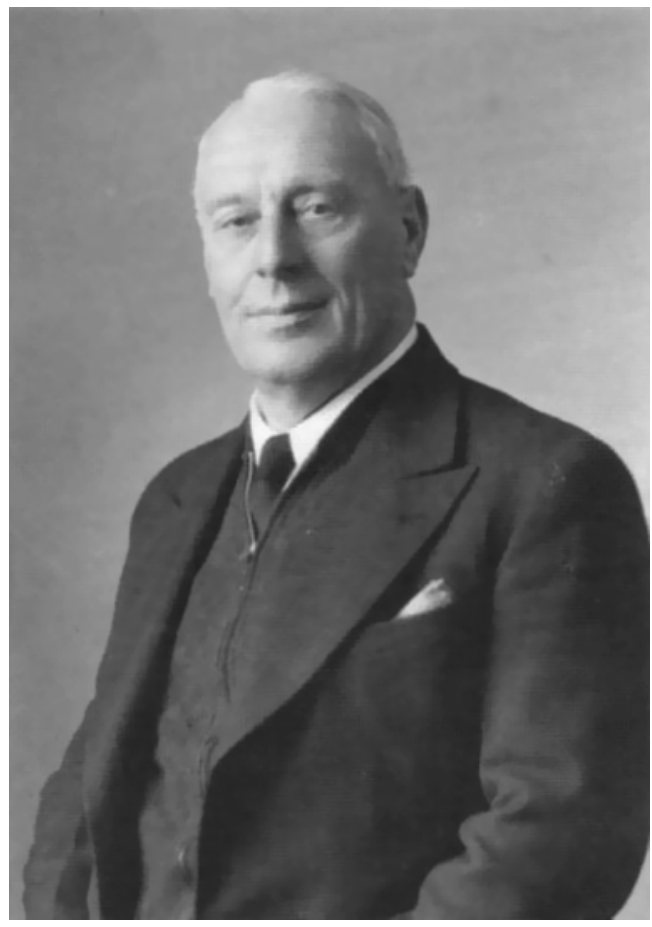

Picture 5.3 Ernest William James. Source: Photographer Unknown, "Picture of Ernest William James" in meiji-portraits.de by Bernd Lepach. Note: Despite his British nationality, he served as Sweden's consul in Kobe.

when it came to further Swedish trade interests. However, he left his position in late 1938 and, therefore, did not work much with Widar Bagge. Guston was replaced first ad interim by G.A. Neville, the manager of the foreign trading company Nickel \& Lyons Co., Ltd, and on May 12, 1939, permanently by R.G. Bell, the owner of another trading company. ${ }^{81}$ The biographies of the honorary consuls show how the Swedish consular network depended on the expatriate community of different countries. Many consuls were not Swedes but either worked for Swedish companies or had close ties with them. This made the positions relatively easy to staff, which contrasts with the situation for career diplomats, where replacements were less frequent and more tedious to achieve. In 1940, a new legation secretary arrived in Tokyo, Erik von Sydow, but only as a replacement for Hugo Wistrand, who was transferred to Berlin. The legation was only enforced from the outside in 1945, through Olof Ripa, who became second secretary, shortly before Bagge left the legation. Ripa stayed after the departure of von Sydow, becoming the last Swedish diplomat in Tokyo, during the American occupation, with the title of "Diplomatic Representative to the Supreme Commander of the Allied Powers." He left Tokyo in 1949.82 


\section{Staying relevant}

\section{Keeping relations alive}

Although Sweden and Japan were both not involved in the early stages of the war in Europe, Bagge was soon confronted with problems that threatened to become serious obstacles to Swedish interests. Swedish-Japanese sea traffic started to deteriorate in early 1940, which coincided with the German occupation of Denmark and Norway in April and the Winter War between Finland and the USSR. With three out of five Nordic countries under (quasi-)foreign control, many observers in Japan believed Scandinavia was no longer of any practical importance in international relations. According to Bagge, the Asahi Shimbun, one of Japan's largest daily newspapers, had written that war events made Japanese diplomatic presence in Sweden unnecessary. ${ }^{83}$ At first, Bagge reported only about newspaper articles that argued in this direction but it was an increasing popular opinion. In early January 1941, the Japanese minister to Sweden, Matsushima Shikao, was one of the diplomats whom Foreign Minister Matsuoka reposted: in his case to Berlin, as a special diplomatic representative for tripartite negotiations. Problematically, Matsuoka did not name a new envoy to Stockholm, which became a headache to the UD since it meant another hurdle for bilateral relations. ${ }^{84}$ Some even worried it signaled Japanese doubts that Swedish independence would last in a Germanoccupied Europe. Bagge held it for "undoubtedly important, from a Swedish point of view, that a Japanese minister is again accredited to Stockholm as soon as possible (...)." ${ }^{85} \mathrm{He}$ quickly paid a visit to the foreign minister to point out that the Japanese media was mistaken in forsaking Scandinavia, and to emphasize that Sweden would still be central for trade with Nordic countries once shipping restarted. ${ }^{86}$ Matsuoka assured that Matsushima's reposting to Germany was a necessity and had nothing to do with Japan's appreciation for Sweden. The delay in sending a new envoy, the foreign minister argued, was solemnly due to a shortage of adequate personnel for the position. ${ }^{87}$ However, either the Gaimushō was running severely low on skilled diplomats or Matsuoka's words were not entirely truthful. Until the end of his tenure, in summer of that year, he did not appoint a new envoy, nor did Matsuoka's successors see any diplomatic value in doing so. It took the Japanese side nearly two years to send a replacement. In the meantime, there were only three Japanese stationed in Sweden with diplomatic status.

Table 5.2 Japanese diplomats in Sweden in 1942

\begin{tabular}{ll}
\hline Position & Name \\
\hline Chargé d'Affaires & Kōda Jōtarō \\
Military Attaché & Onodera Makoto \\
Deputy Military Attaché & Higuchi Fukashi \\
\hline
\end{tabular}

Source: Swedish Academy of Science, Sveriges Statskalender för airet 1942 [Sweden's State Calendar for 1942], ed. Vetenskapsakademin (Uppsala: Almquist \& Wiksells, 1942), 54. 
The Gaimushō did not even appoint a consul to the city of Stockholm during this period. The only additional staff was an honorary consul working in Gothenburg. That person was, however, a Swede (Tor E.J. Broström) who had been filling that administrative position since $1934 .{ }^{88}$ And the military attaché and his deputy were not sent to Sweden by the Gaimushō but by the authorities of the army. That there was only a single representative of the Gaimushō-the chargé d'affaires - strongly suggests that it did not have much interest in Sweden as an outpost of trade and diplomacy. For two long years, Stockholm remained largely neglected despite the fact that Sweden became a Protecting Power for Japan after 1941. The Gaimushō obviously judged that one chargé d'affaires in Stockholm and a Swedish minister in Tokyo were enough for the management of bilateral relations.

In Tokyo, Bagge was confronted with another problem: the security of his compatriots and his own legation. In July 1941, he cabled to the UD that "considering the uncertain situation" the secret archives of the legation had become a liability and that he wished to destroy them. ${ }^{89}$ Although there was no danger to the diplomats per se-the Gaimusho had always respected international norms like diplomatic immunity — whether the military police, the Kenpeitai, would keep to the same standards was a different question. Should there be a fallout between Sweden and Japan, his legation might be in danger. Although no such event occurred, Bagge's fears were not unfounded. Enemy embassies and legations were indeed searched before they were sealed by the Kenpeitai once the war with the allies broke out later that year. Even without that foresight, signs of the deteriorating security situation for Westerners in Japan were clear to the expatriate community. Bagge reported that the dangers for all foreigners in Japan had risen over the past year. Although Sweden was not part of the Anglo-American bloc, with whom war was becoming ever more likely, that was no guarantee for the safety of Swedish citizens from the Kenpeitai. "The possibility of Japan's entry into the war carries special risks for its white inhabitants in view of the strong increase in xenophobia." ${ }^{90}$ Especially pressure against British nationals had been mounting with the worst incident occurring on July 27, 1940, when 12 Britons (all distinguished businessmen or professionals) were arrested across the country in a coordinated stunt against what was feared to be espionage activities. Both of Sweden's British consuls, Frederik Ringer of Nagasaki and Ernest James of Kobe, were among the arrested, on charges of violating the law on military secrets. ${ }^{91}$ James was released from custody after five days, but Ringer remained detained for over a month. He was released eventually but died later that year (whether his death was connected to the incident cannot be judged from the available records)..$^{92}$ Another detainee, Melville James Cox, a Reuters journalist, died in custody after falling from the third floor of the Kenpeitai headquarter two days after the arrest. ${ }^{93}$ The Japanese police reported the incident as a suicide, while British investigations found that Cox probably succumbed to intense mental pressure during the interrogation and leaped to his death. There were no indications for direct foul play. ${ }^{94}$ Nevertheless, among members of the foreign community in Tokyo, Kobe, and Osaka, many believed in a targeted assassination. ${ }^{95}$ It was a watershed moment for the foreign 


\section{Staying relevant}

community that marked the deterioration of the personal security situation and led to the departure of many in the expatriate community. Even long-term residents like James, who had been born and raised in Japan, decided to leave the country. Politically, Japan had become a hostile place.

Naturally, these developments were of great concern to Bagge. However, pressed with the question if Sweden should take action diplomatically, he advised against an official Swedish statement. Neither an evacuation of the Swedish colony nor a repatriation recommendation was warranted, in his opinion. He assured his ministry that he was in close contact with the Swedish companies to ensure that they took care of the safety of their employees and that companies would check the validity of employee passports but he also argued that "total evacuation

(...) seems excluded considering the financial interests of the companies." 96 The circumstances were not ideal, but they were not a life-or-death matter in his opinion. Maintaining Sweden's commercial position was more important than escaping the suspicions of certain circles in Japan. At the same time, he recognized how serious the situation had become, which is why he left the choice of remaining or leaving Japan to the concerned individuals. Consequently, a set of questions was sent to the 100 people of the expatriate community to inquire about their wishes. By September 1941, only 13 Swedes (which included two children) wished to be repatriated. Everybody else preferred to stay. ${ }^{97}$

\section{Trade}

\section{Keeping commerce alive}

International developments had spared Sweden from being dragged into the war in Europe and, simultaneously, deterred Japan from entering the fight on Hitler's side. The situation had also silenced Swedish criticism on Japanese actions in China, setting a course for Swedish-Japanese relations to continue on a "business as usual" basis. Once it was clear that Japan would seek a neutral position, Japanese and American newspapers predicted a considerable economic upswing, because during the First World War neutral trade also initially increased..$^{98}$ Although this could have heralded a new era of economic collaboration between Stockholm and Tokyo, obstacles soon emerged. The first visible trace thereof is the almost complete lack of trade records for the years 1940-1945 in the Swedish statistical yearbooks. The only official information available is import figures for 1944 and 1945, according to which Sweden received goods of a value of SEK 634,000 and SEK 277,000, respectively. Although these numbers mean that trade between Sweden and Japan never completely ceased, it represents only 5 percent of the SEK 10 million worth of goods imported in 1939. Japanese statistics are equally spotty although they record trade for a longer period into the war. For goods exported to Sweden, data was recorded up until 1941. Surprisingly, data on imports from Sweden was collected for every year until 1945, which is an astonishing testimony to Japan's administrative capacity when it came to import controls even while its empire was falling apart. These figures show that Swedish-Japanese bilateral trade gradually collapsed. 


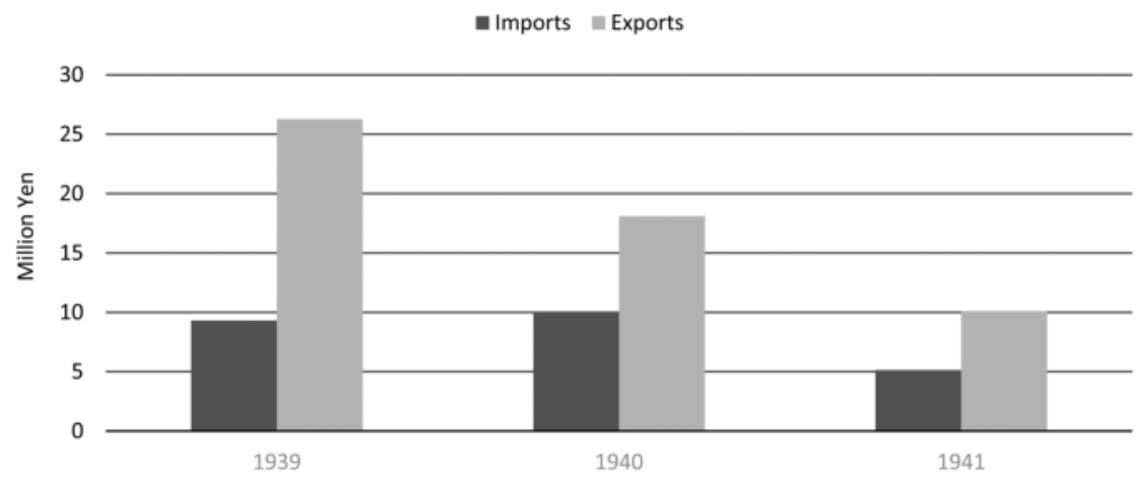

Figure 5.2 Swedish imports and exports to Japan 1939-1941. Source: Data from Honma, Nippon keizai tōkeishū 1868-1945, 35-47.

Between 1939 and 1941, the value of Swedish goods to Japan declined roughly 30 percent annually. ${ }^{99}$

Bagge was naturally trying to forestall the trend but 1940 turned out to breed ever new trade hurdles. Port calls of Swedish ships to Japanese harbors halved. The sea link between Sweden and Japan suffered from the dangerous situation in European waters. The land route via Siberia, Moscow, and Tallinn to Stockholm had, therefore, gained importance, but in August, the Soviet Government started to require certificates of origin for the transport of Japanese goods. Those could only be obtained through the Soviet embassy in Tokyo but "not without difficulties," as Bagge put it in a report in September $1940 .{ }^{100}$ He requested the UD to negotiate minimum fright contingents and install a local agent in Vladivostok to help expedite cargo clearance of Japanese goods traded by Swedish companies. ${ }^{101}$ That strategy seemed to work for the first few months with encouraging signs from the Japanese side as well. Bagge received the principal agreement by the Japanese finance minister that the export to Sweden of non-vital goods would still be allowed in the upcoming months. Trade numbers for the running period were still healthy. $\mathrm{He}$ reported that between August 19 and October 23, he had legalized documents for the transit of 3,030 tons of cotton, wool, and knitted goods for a total value of $¥ 6.4$ million. ${ }^{102}$ Considering that the UD had declared in February of the same year that it would use a one-to-one exchange ratio (one crown for one yen), that was a very high two-month average of exports, even in comparison to $1939 .{ }^{103}$ Around half of the transports were done via Siberia and the other half by ship. ${ }^{104}$ But the trend did not last long. Already in early January 1941, cargo transport through Siberia was suspended because of Soviet measures that required routing traffic solely to the German Königsberg (Kaliningrad) and Japan Railway's lower capacity for that route. This would have culminated in additional taxes and applications for waybills that made the transport all but impossible. The Swedes had to wait for the conclusion of Soviet-Japanese transit agreements as well as themselves negotiate with Japan Railways for additional space on their Siberian lines. ${ }^{105}$ 


\section{Staying relevant}

The sea route suffered, too. Whereas for 1938, a total of 47 Swedish ships called at the port of Yokohama and the following year still 40 were registered, the number fell to 25 in 1940 and not a single port call to Yokohama in 1941. ${ }^{106}$ Not only did the sea passage become more dangerous due to the war in Europe, but it also became much more cumbersome. Britain started patrolling the sea, demanding that neutral cargo must obtain its "navicerts" to be allowed to pass. A navicert - short for navigational certificate - was a document akin to a passport for neutral trade, which testified that the cargo on neutral ships was not destined for an enemy port. The navicert system was a British attempt at beating Germany by policing the high sea with its extensive maritime power. Different from passports, navicerts could not be issued by the country that wanted its goods to be traded but only by the British Government through its diplomatic representations abroad. Those could refuse the issuance if trade with the enemy was suspected or if goods had been (unilaterally) declared contraband. ${ }^{107}$ Thereby, navicerts became an instrument to expand the policy of sea blockades against enemy nations-a policy that was an infringement on international law but had worked well for Britain already in the First World War. ${ }^{108}$ To seafaring neutrals like Sweden, it was a heavyhanded infringement on the right to trade with both belligerents. However, since Great Britain with its extensive fleet controlled large portions of the Atlantic and the Pacific Oceans, there was little that could be done against the unilateral policy. Therefore, Bagge had to continuously apply for navicerts. The process could take weeks as it necessitated proof of the final destinations of the goods (separate cargo needed separate navicerts) and they were frequently rejected. ${ }^{109}$ During 1940 and 1941, Bagge and the UD repeatedly protested the withholding of navicerts for Swedish ships from or to Japan, usually to little avail. Many trade initiatives came to a late end because even when they were successfully negotiated between Swedish and Japanese stakeholders, their shipment could become impossible. The largest setback in this regard was the attempted export of Swedish nickel and cadmium of 125 tons and 12 tons, respectively, in October 1941. The sale had been in preparations for months, just to fail to receive British navicerts. ${ }^{110}$ It was a clear sign for London's distrust of Tokyo, which had not yet become a participant of the war. From May 1940 onward, refusals of navicerts for all Swedish-Japanese trade became the norm. ${ }^{111}$ In short, export and import became more and more difficult as the political situation and the security on the traffic routes deteriorated. Almost every shipment had to be negotiated with at least two or three actors like Japan, the USSR, Britain, Germany, and sometimes also Japanese railway companies. Goods had to pass through territories on land or sea which they controlled and demanded licenses for. However, the Swedes did not give up. As late as March 1941, Bagge reported to the foreign ministry that there was "significant Japanese interest" for the import of Swedish pulp, paper, and steel for a value of $¥ 7$ million through Mitsubishi Corporation. He argued that his ministry should use this opportunity to demand from Japan imports of equal value. ${ }^{112} \mathrm{He}$ was most likely eying for an increase in soybean imports from Manchukuo. However, trade reciprocity went both ways. To grant an import permit for these products, Japanese authorities requested a state guarantee from Bagge that Sweden would 
import goods from Japan of equal value. It was not acceptable to the Japanese side that the old trade deficit with Sweden would continue, even when it was the big Japanese firms, Mitsui and Mitsubishi, that requested these goods. ${ }^{113}$

Furthermore, the worsening political situation between Japan and the United States led Japan to openly consider the abolition of US dollars to pay for Japanese goods on world markets and instead switch to German Reichsmark for trade with Europe. Sweden's largest exporter, SKF, had already started negotiations with its trading partners to settle bills in German currency but Bagge came up with a different idea: a genuine Swedish-Japanese clearing system. The move was supposed to eliminate the need for a third intermediary currency and, thereby, remove the uncertainty about the availability of money. Bagge proposed to clear exchange directly through a Swedish-crown denominated account for Japan at the Enskilda Banken, a private bank, and a Swedish-owned yen account at the Yokohama Specie Bank (YSB). ${ }^{114}$ Bagge's proposal found open ears on both sides, especially the YSB was eager to move the plans forward. On the Swedish side, adjustments were made that excluded Enskilda Banken. But, in the end, the deal was implemented between the YSB and Sweden's central bank, the Riksbank. With the consent of Gunnar Hägglöf, the head of the UD's trade department, the agreement came into force on May 28, 1941. ${ }^{115}$ However, world affairs once again overturned strategic planning. Operation Barbarossa - the German invasion of the Soviet Union-started less than a month later, on June 22, turning Japan's military ally, Germany, into an enemy of the USSR. Despite the fact that Japan, as we have seen, remained neutral toward the Soviet Union, the upheaval that the German attack created was tremendous. All trade to and from Europe stopped for weeks. ${ }^{116}$ Goods from the Japanese mainland, as well as exports from Manchukuo, could not be transported via Siberia because the Königsberg had become enemy territory to the Soviet Union and the Estonian port of Tallinn was now a warzone. Only the limited sea link offered some possibilities for goods to leave or enter Japan, but those consignments were traded in German Reichsmark, Argentinian Pesos, or Swiss Francs. ${ }^{117}$ The Swedish-Japanese clearing system had, in this regard, only a limited impact. Especially in later years, the currency of Switzerland, the Swiss Franc, was more popular than the Swedish crown in Japan because it had a wider use in international transactions, owing to the dominance of the Swiss National Bank in international finance and the fact that the Swiss Franc was also the house currency of the Basel-based Bank for International Settlements, which operated throughout the war. ${ }^{118}$ However, the direct clearing system between Sweden and Japan remained an option for the settlement of payments when both sides accepted the other currency from which Swedish trading companies could benefit occasionally.

\section{Summary}

By the time Hitler attacked Poland, the Swedish attitude toward Japan had come full circle. It had moved from a relationship defined mainly by trade interests before 1930 , to one of "trade under protest" during the early years of Japan's expansionism, back to trade without protest when it became clear that international 


\section{Staying relevant}

anarchy was becoming the norm again. Developments at the League of Nations were pivotal for that shift. After the failure of sanctions against Italy and Japan, and a joint declaration of European neutrals, Swedish foreign policy became increasingly cautious. The new global situation with antagonistic Great Power blocs and diminishing respect for international treaties was indeed alarming, leading to calls for a return to Swedish neutrality. At the beginning of the 1930s that policy had only few friends among Swedish politicians. It was commonly emphasized that neutrality was incompatible with League membership. ${ }^{119}$ However, the winds changed between 1936 and 1939. After a period of internal struggle, all governmental parties agreed to support the return to Swedish neutrality, effectively abandoning the collective security approach through the League. At the same time, Japan, too, opted for a neutral policy in the ensuing European war, under the guise of "noninvolvement." Deterred by the Soviet Union in Nomonhan and surprised by Germany's sudden Non-Aggression Pact with Stalin, Tokyo chose to focus on its warfare in China while maintaining normal relations with all others. In comparison with Sweden, the Japanese approach came with the important difference that the Empire kept the option open to join the war in the future. Under these circumstances, Swedish-Japanese trade could have continued as usual after 1939, but it was eventually slowed down by external circumstances. The dangers of the high seas in connection with Britain's insistence to control commerce to and from Europe through navicerts and the difficulties to obtain permits from the Soviet Union for transit through Siberia resulted in a decline in trade. Inside Japan, the situation became more dangerous to Swedish citizens due to the rise of attacks against Westerners. But neither Minister Widar Bagge nor the UD believed that the situation warranted an evacuation. Only 10 percent of the Swedish colony left the Empire before the attack on Pearl Harbor. All in all, during the first two years of the War in Europe, Swedish-Japanese relations took a clear turn toward bilateralism, with an increasing role of Swedish diplomacy in trade questions. It was a trend that would become more pronounced during the dramatic years of the War in the Pacific.

\section{Notes}

1 Social-Demokraten, "England uppger Kina" [Britain surrenders China], July 26, 1939; Svenska Dagbladet, "Från tålamod till eftergift?" [From patience to concessions?], July 29, 1939; Svenska Morgonbladet, "Damoklessvärdet över Tokio" [Sword of Damocles over Tokyo], July 29, 1939.

2 United States, Peace and War: United States Foreign Policy 1931-1941 (Washington, DC: Government Printing Office, 1943), 475.

3 S.C.M. Paine, The Wars for Asia 1911-1949 (Cambridge: Cambridge University Press, 2012), 142.

4 Ibid., 144.

5 Stig Hadenius, Modern svensk politisk historia: Konflikt och samförstånd [Modern Swedish political history: Conflict and consensus] (Stockholm: Hjalmarson \& Högberg, 2003), 72-75; Gilmour, Sweden, the Swastika and Stalin, 35-36.

6 Gunnar M. Hägglöf, Svensk krigshandelspolitik under andra världskriget [Swedish trade policy during World War II] (Stockholm: Norstedt, 1958), 116, 
21; Ingela Karlsson, "Staten och rederierna. Den svenska handelsflottan 1937 1947" [War, state, and shipping companies. The Swedish merchant fleet, 19371947] (PhD diss., Gothenburg University, 2003), 43, 88; Ingela Karlsson, "Sig själv närmast" [Every man for himself] in En (o)moralisk handel? Sveriges ekonomiska relationer med Nazityskland [(Im)moral trade? Sweden's economic relations with Nazi Germany], ed. Charlotte Haider (Stockholm: Forum för levande historia, 2006), 24. See also chapter 1.

7 Wilhelm Agrell, Fred och fruktan. Sveriges säkerhetspolitiska historia 1918-2000 [Peace and fear. The history of Swedish security policy, 1918-2000] (Lund: Historiska Media, 2000), 61-62; Hadenius, Modern svensk politisk historia, 75-76.

8 Hadenius, Modern svensk politisk historia, 76-77.

9 Agrell, Fred och fruktan, 68, 77. See also notes of April 21, 1942, in Sven Grafström, Anteckningar 1938-1944, [Notes 1938-1944], ed. Stig Ekman (Stockholm: Kungliga Samfundets handlingar, 1989), 14. Grafström was a Swedish diplomat, secretary of the parliamentarian Foreign Policy Committee and, from 1941, employed at the foreign ministry's press section.

10 Agrell, Fred och fruktan, 75-76.

11 Hadenius, Modern svensk politisk historia, 81-85; Agrell, Fred och fruktan, 63-67.

12 Social-Demokraten, "Det mörka minnet" [The dark reminiscence], July 30, 1939; see also Göteborgs Handels- och Sjöfartstidning, "Amerika tager till orda" [America takes the floor], July 29, 1939.

13 Ingemar Ottosson, "Fujiwara Ginjirō och Japans möte med Sverige" [Fujiwara Ginjirō and Japan's encounter with Sweden], Orientaliska studier [Oriental Studies], no. 161, Stockholm, 2020, 56-7. According to Fujiwara, the propagation of the Japanese tea ceremony is an important method for cultural diplomacy, see Ginjirō Fujiwara, Bōkan sannen [Three years of work and leisure] (Tokyo: Tōyō Keizai Shinpōsha, 1942), 296-297; Shikao Matsushima, "Mission to Sweden," Svensk-Japanska Sällskapets ärsskrift [Yearbook of the Swedish-Japanese Association], Stockholm, 1940, 7. According to the directory of the Swedish-Japanese Association, it had 221 members in 1939, many of them from commerce and industry. Compared to some other similar associations, it was not an impressive figure but it represented an alltime high in the history of the Swedish-Japanese Association (ibid., 47-50) Symptomatically, Matsushima worked at the Trade Bureau of the Gaimushō which he had headed since 1936. He had also been stationed in Manchukuo. See "Matsushima Shikao" in Nihon gaiko shi jiten [The encyclopedia of Japanese diplomatic history. New ed.] (Tokyo: Yamakawa Shuppansha, 1992), 954.

14 Bernhard Karlgren, Japans väg och mål [Japan's path and goal] (Stockholm, 1940), 15-30.

15 Data obtained from searching the database "Svenska Dagstidningar" [Swedish Newspapers] at the Royal Library of Sweden Stockholm, for the period 19301946.

16 Malmborg, Neutrality and State-building in Sweden, 90-120.

17 Classina Albertina Kluyver, ed. Documents on the League of Nations (Leiden: International Intermediary Institute, 1920), 168-183, 240-250.

18 For a detailed account on Swedish attitudes toward the League, see Ingemar Ottosson, Krig i fredens intresse eller neutralitet till varje pris?: Sverige, NF och frågan om kollektiv säkerhet 1935-1936 [War in the interest of peace or neutrality at any cost?: Sweden, the League of Nations, and the question of collective security, 1935-1936] (Lund: Studentlitteratur, 1986).

19 Article 16 of the Covenant mandates that "should any Member of the League resort to war in disregard of its covenants (...), it shall ipso facto be deemed 
to have committed an act of war against all other Members of the League, (...)." The strong wording of the article meant that the League had, in fact, the character of a military alliance. Its modern-day analog would not be the United Nations (the successor of the League) but the North Atlantic Treaty Organization (NATO), which is the only military organization (as of the early 2020s) that promises a similarly strong adherence to the musketeer principle of "one for all, all for one."

20 John Ross, Neutrality and International Sanctions: Sweden, Switzerland, and Collective Security (New York: Praeger, 1989), 80.

21 Ottosson, Handel under protest, 289; Communist MP Hilding Hagberg rhetorically asked what China could have possibly gained by declaring itself neutral in 1937 (RP, 1939 AK, No. 4, 65).

22 For an overview of the Abyssinia debate at the League of Nations, see Byron Walfred Hunt, "The League of Nations and the Italo-Ethiopian Conflict," (PhD diss., University of Montana, 1957), 86-109.

23 RP, 1936 FK, No. 36, 15.

24 Ross, Neutrality and International Sanctions, 81.

25 Ibid.

26 RP, 1936 FK, No. 36, 33.

27 Ibid., 48.

28 Ibid., 26.

29 "Documents Relating to the Question of the Application of the Principles of the Covenant," League of Nations Official Journal, Special Supplement no. 154 (Geneva, 1936), 19.

30 Sandler, Strömväxlingar och lärdomar, 62. The speech was well noted by international media and political commentators. See Neue Zürcher Zeitung, "Schweden und der Völkerbund: Die Rede Sandlers in Uppsala" [Sweden and the League of Nations: Sandler's speech in Uppsala], November 14, 1937. See also Hans J. Morgenthau, "The Resurrection of Neutrality in Europe," American Political Science Review 33 (1939), 473-474.

31 Ibid., 474.

32 See, e.g., the discussion in the Riksdag in RP, 1938 FK, No. 40, 33.

33 Declarations of neutrality were not necessary for a country to acquire the status of a neutral power. They were, however, often issued to preempt misunderstandings.

34 Nakamura, Shōwashi, 228-234; Takemaro Mori, Ajia Taiheiyō sensōo [Asia Pacific war] (Tokyo: Shūeisha, 1993), 137-158; Michael A. Barnhart, Japan Prepares for Total War: The Search for Economic Security, 1919-1941 (Ithaca: Cornell University Press, 1987), 95-96.

35 Bagge to Sandler, Report, July 24, 1939 (UDA, 2210.03.1, HP 1, Xj, XV).

36 Article 3 of the "Pact of Friendship and Alliance between Germany and Italy." Original text in German in: Franz Alfred Six, ed. Dokumente der Deutschen Politik: Das Werden des Reiches, [Documents of German politics: The establishment of the Reich] vol. 7 (Berlin: Junker und Dünnhaupt, 1940), 49-50.

37 Bagge to Sandler, Report, July 24, 1939 (UDA, 2210.03.1, HP 1, Xj, XV).

38 Stuart D. Goldman, Nomonhan, 1939: The Red Army's Victory that Shaped World War II (Annapolis: Naval Institute Press, 2012).

39 See, e.g., "Cabinet keeps close watch on Polish crisis," The Japan Times, September 3, 1939.

40 The Japan Times, "Abe stresses China Affair is No. 1 Issue," September 1, 1939.

41 The New York Times, "Japan Determined to Remain Neutral," September 5, 1939. 
42 Newe Zürcher Zeitung, "Die Japanische Neutralitätspolitik” [Japan's Neutrality Policy], September 6, 1939.

43 Douglas Howland, "Japanese Neutrality in the Nineteenth Century: International Law and Transcultural Process," Journal of Transcultural Studies 1, no. 1 (2010).

44 The reports are titled "Precedent of declaration of neutrality as executed by Japan," and "Legal opinion about neutrality" (JACAR, B04013434900 and B04013453600, 1939).

45 Speech to the US public on September 3, 1939, by Franklin D. Roosevelt. In Fireside Chat, ed. Gerhard Peters and John T. Woolley, The American Presidency Project, https://www.presidency.ucsb.edu/node/209990.

46 The Japan Times, "Japan to Stay Clear of War, Abe Declares," September 6, 1939.

47 See, e.g., Aftonbladet, "Roosevelts ja och nej" [Roosevelt's yes or no] September 28, 1940; Göteborgs Handels- och Sjöfartstidning, "Och Ryssland" [And Russia] September 28, 1940; Social-Demokraten, "Den nya trippelalliansen" [The new Triple Alliance] September 30, 1940.

48 Ian Nish, Japanese Foreign Policy 1869-1942: Kasumigaseki to Miyakezaka, Foreign Policies of Great Powers (London: Routledge, 1977), 235.

49 Bagge to UD, Report, November 18, 1940 (UDA, 2210.03.1, HP 1, Xj, XV).

50 Nish, Japanese Foreign Policy 1869-1942, 237-239.

51 Boris Slavinsky, The Japanese-Soviet Neutrality Pact: A Diplomatic History, 1941-1945, trans. Geoffrey Jukes (London: RoutledgeCurzon, 2004).

52 Nish, Japanese Foreign Policy 1869-1942, 244.

53 Slavinsky, The Japanese-Soviet Neutrality Pact, 61-65.

54 Söderblom at UD to Adlercreutz, Telegram, Defense Staff, and Mission Chiefs, July 5, 1941 (UDA, 2210.03.1, HP 1, Xj, XVI).

55 Pascal Lottaz, "Neutrality and Wartime Japan," in Notions of Neutralities, ed. Pascal Lottaz and Herbert R. Reginbogin (Lanham: Lexington, 2019).

56 Diplomatic Documents of Switzerland (DDS), Debâcle au Soleil-levant: Journal de Camille Gorgé [Fiasco in the Land of the Rising Sun: Diary of Camille Gorgé]. Entry dated July 30, 1943. dodis.ch/50633.

57 G.A. Lensen popularized the term "strange neutrality" but he could not have known of Gorgé's use of the same expression as the latter's memoirs were not published until 2017. See George Alexander Lensen, The Strange Neutrality: Soviet-Japanese Relations during the Second World War, 1941-1945 (Tallahassee: The Diplomatic Press, 1972).

58 Swedish translation of Undén's address (UDA, 2210.03.1, HP 1, N, XI). However, a memorandum before the session of the Advisory Council on Foreign Affairs (UN), January 3, 1938, makes it clear that Sweden did not plan to terminate its membership of the League and that it was going to await how the sanctions debate developed (UDA, 2210.03.1, HP 1, N, XI). Undén himself continued to praise the Swedish membership until summer 1939 (RP, 1939 FK, No. 39, 47; RP, 1938 FK No. 40, 46-47).

59 "Vrida vrång värld rätt omöjligt för Norden. Parollen bör nu vara 'fred för Norden" " [To wind an evil world in the right direction impossible to Northern Europe. The slogan now should be 'Peace for the Nordic Countries'], Svenska Morgonbladet, April 5, 1938.

60 Minutes concerning foreign affairs, Cabinet meetings of January 14 and May 6, 1938, and January 12, 1939 (NF-byrain, B 1).

61 Meeting between Envoy Kuriyama and acting Foreign Minister K.G. Westman, October 17, 1938. See Memorandum, October 26, 1938 (UDA, 2210.03.1, HP 37, A, XI).

62 Aktstycken, 1938, 70-1. A secret Chinese telegram sent by Kong Xiangxi, Vice Chairman of the Executive Yuan, to the ambassador in Paris in 1938 (undated) 


\section{Staying relevant}

claimed that China could no longer expect much from the small states (see GMS/S, A.1.1.0.30-23-the encrypted telegram was deciphered by the Japanese). Envoy K.I. Westman reminded a Chinese representative in Geneva that it was dangerous for small states if certain clauses in the Covenant were seen as binding, and others not. See Westman to UD, November 7, 1938 (UDA, 2210.03.1, HP 37, A, XI). See also Westman to UD concerning Sandler's meeting with Gu Weijun, September 15, 1938 (HP 37, A, X).

63 H. Beck-Friis, Memorandum, May 10, 1939 (UDA, 2210.03.1, HP 37, A, XIV).

64 UD of the Republic of China to Swedish Government, Memorandum, July 27, 1939 (UDA, 2210.03.1, HP 37, A, XV); Erik Kronvall (Shanghai) to UD, August 8, 1939 (ibid).

65 "Resolution for the Dissolution of the League of Nations, Adopted by the Assembly on April 18, 1946," International Organization 1, no. 1 (1947).

66 See chapter 6.

67 Biographic information from: Sweden. Utrikesdepartementet. "Kungl. utrikesdepartementets kalender" (Almqvist \& Wiksell, 1938), 149; Bert Edström, "Widar Bagge, Japan and the End of the Second World War," Center for Pacific Asia Studies, Working Paper no. 41 (1995), 2. See also the obituary in Svenska Dagbladet, April 25, 1970.

68 Published and unpublished memoirs of World War II diplomats are extensive. Concerning Japan, the following are the most important personal accounts: Robert Craigie, Behind the Japanese Mask (London: Hutchinson \& Co., 1945); Joseph C. Grew, Ten Years in Japan (New York: Simon \& Schuster, 1944); John Pownall Reeves et al., The Lone Flag: Memoir of the British Consul in Macao during World War II (Hong Kong: Hong Kong University Press, 2014); Shigenori Tōgō, The Cause of Japan (Westport: Greenwood Press, 1977); Fumimaro Konoe, Konoe Fumimaro shuki: heiwa e no doryoku [Notes by Konoe Fumimaro: The peace efforts] (Chūōkōron Shinsha, 1947); Mamoru Shigemitsu, Japan and Her Destiny: My Struggle for Peace, ed. Francis S.G. Piggot, trans. Oswald White (London: E.P Dutton \& Co., 1958); Rodolfo Moreno, Más allá del Oriente [Beyond the East] (Buenos Aires: Editorial Sudamericana, 1946). See also Camille Gorgé's account in DDS, Debâcle au Soleil-levant.

69 For this research, Ingemar Ottosson, Bert Edström, and Pascal Lottaz have searched for pictures of Widar Bagge. Neither his niece, Lillebil Bagge, nor the relatives of his former colleague, Erik von Sydow, found any pictures of Bagge in their photograph collections. The two newspaper pictures were discovered by an expert archivist, Ronny Andersson.

70 See also the description of Bagge in Chapter 7, by Bert Edström.

71 Craigie, Behind the Japanese Mask, 98.

72 See Chapter 7.

73 Shigemitsu, Japan and Her Destiny, 339.

74 DDS, Debâcle au Soleil-levant. Entry dated August 10, 1943.

75 Ibid. Entry dated December 16, 1944.

76 Number based on Bagge's assessment in 1941. Bagge to UD, Telegram, September 5, 1940 (BA, 230033.2, E2, I).

77 Switzerland added one honorary consulate in Dairen in 1939.

78 Sweden. Utrikesdepartementet, Kungl. utrikesdepartementets kalender, 70.

79 Before June 18, 1937: John S. Widenfelt.

80 On the James Family, see the historiographic database of Bernd Lepach, Meiji Portraits. Accessible at meiji-portraits.de.

81 Neville had functioned as Guston's replacement during his absences before but was asked in late 1938 to function as consul until a permanent consul could 
be found. He was not entirely happy with this situation as he commenced asking about the progress of the situation from May 1939. See Neville to Bagge, Letters, May 8, 1939; Guston to Bagge, April 26, 1937; and Bell to Bagge, May 12,1939 (BA, 230033.2, E4, III).

82 Norstedts, ed., Vem är det? [Who is it?] (Stockholm: Kungl. Boktryckeriet, 1939).

83 Bagge to UD, Letter, February 20, 1941 (UDA, 2210.03.1 HP 1, Xj, XV).

84 Bagge to UD, Telegram, January 11, 1941 (BA, 230033.2, E2, I).

85 Bagge to UD, Letter, February 20, 1941 (UDA, 2210.03.1, HP 1, Xj, XV).

86 Whether he believed in this assessment is difficult to judge.

87 Bagge to UD, Letter, February 20, 1941 (UDA, 2210.03.1, HP 1, Xj, XV).

88 Swedish Academy of Science, Sveriges Statskalender för året 1942 [Sweden's State Calendar for 1942], ed. Vetenskapsakademin [Academy of Science] (Uppsala: Almquist \& Wiksells, 1942), 54.

89 Bagge to UD, Telegram, July 25, 1941 (BA, 230033.2, E2, I).

90 Bagge to UD, Telegram, August 30, 1941 (BA, 230033.2, E2, I).

91 Bagge to UD, Letter, September 27, 1940 (UDA, 2210.03.1, HP 1, Xj, XV). See also Bagge to UD, Telegram, August 1, 1939 (BA, 230033.2, E2, I).

92 Bagge to UD, Telegram, September 2, 1940 (BA, 230033.2, E2, I).

93 Bagge to KUD, Report, August 9, 1940 (UDA, 2210.03.1, HP 1, Xj, XV).

94 Hugh Cortazzi, "The Death of Melville James Cox (1885-1940) in Tokyo on 29 July 1940: Arrests of British Citizens in Japan in 1940 and 1941," in Britain and Japan: Biographical Portraits (Leiden: Global Oriental, 2013).

95 Donzé et al., Journal d'un témoin, 52.

96 Bagge to UD, Telegram, September 5, 1941 (BA, 230033.2, E2, I).

97 Bagge to UD, Telegram, September 8, 1941 (BA, 230033.2, E2, I).

98 The Japan Times, "Japanese, American Shipping Gains Business during Crisis," September 7, 1939; "Japanese Press Opinion," September 7, 1939; "Neutral Powers Will Prosper, Babson States," September 9, 1939.

99 Honma, Nippon keizai tōkeishū 1868-1945, 40.

100 Bagge to UD, Telegram, September 9, 1940 (BA, 230033.2, E2, I)

101 Bagge to UD, Telegrams, September 21 and October 22, 1940 (BA, 230033.2, E2, I).

102 Not all of it was Swedish trade though. The minister admitted that Swedish companies were only responsible for about 600 tons per month (a bit more than a third of the total transit volume). The rest he legalized for other companies, probably with the goal of re-exporting the goods from Sweden to their final destinations. See Bagge to KUD, Telegram, October 25, 1940 (BA, 230033.2, E2, I).

103 On the exchange rate, see Bell to Bagge, Letter, February 2, 1940 (BA, 230033.2, E4, III).

104 Bagge reported in a telegram in January 1941 that the transit of KR 3 million went through Siberia for the months of September, October, and November. See Bagge to UD, Telegram, January 22, 1941 (BA, 230033.2, E2, I).

105 Bagge to UD, Telegrams, January 8, 18, and 24, and February 13 and 22, 1941 (BA, 230033.2, E2, I).

106 Yokohama consulate, Quarterly Report (BA, 230033.2, E4, III).

107 Stephen C. Neff, The Rights and Duties of Neutrals: A General History (Manchester: Manchester University Press, 2000), 182-183.

108 On Navicerts and their history, see Neff, The Rights and Duties of Neutrals, 149150; Herbert R. Reginbogin, Faces of Neutrality: A Comparative Analysis of the Neutrality of Switzerland and other Neutral Nations during WW II (Berlin: Lit Verlag, 2009), 63. 


\section{Staying relevant}

109 Bagge to UD, Telegram, March 3, 17, and 28, 1941 (BA, 230033.2, E2, I).

110 Bagge to UD, Telegram, September 24, 1941, and October 3, 1941 (BA, 230033.2, E2, I).

111 Bagge to UD, Telegram, May 20, 1941 (BA, 230033.2, E2, I).

112 Bagge to UD, Telegram, March 21, 1941 (BA, 230033.2, E2, I).

113 Ibid.

114 The Enskilda Bank was frequently used by the Swedish Government for trade negotiations with all belligerents of the war. It was founded by André Oscar Wallenberg, the father of Gustaf Oscar Wallenberg, the above mentioned first Swedish minister to Japan.

115 On the clearing agreement, see Bagge to UD, Telegrams, November 2 and 11, and December 27, 1940, as well as June 21 and December 3, 1941 (BA, 230033.2, E2, I).

116 Bagge to UD, Telegrams, July 3 and 14, 1941 (BA, 230033.2, E2, I).

117 Bagge to UD, Telegrams, November 25, 1941 (BA, 230033.2, E2, I).

118 On the World War II dealings of the Bank for International Settlements see Pascal Lottaz and Herbert Reginbogin, "'Private Neutrality'-The Bank for International Settlements," in Notions of Neutralities, ed. Pascal Lottaz and Herbert Reginbogin (Lanham: Lexington, 2019); Roger Auboin, "The Bank for International Settlements 1930-1955," in Essays in International Finance, ed. Gardner Patterson (Princeton: Princeton University, 1955); Gian Trepp, Bankgeschäfte mit dem Feind: Die Bank für Internationalen Zablungsausgleich im Zweiten Weltkrieg: Von Hitlers Europabank zum Instrument des Marshallplans [Baking with the enemy: The bank for international settlements in the Second World War: From Hitler's Europe bank to an instrument of the Marshall plan] (Munich: Rotpunktverlag, 1997).

119 Ottosson, Krig i fredens intresse, 5. As late as in 1935, Nikolaos Politis, a prominent statesman in Geneva, had declared that the concept of neutrality was dead. Nikolaos Politis, Neutrality and Peace, trans. Francis Crane (Washington, DC: Carnegie Endowment for International Peace, 1935). 


\section{Fully engaged \\ Total war in the Pacific}

\section{International politics}

\section{A new war in the Pacific}

The recent developments in Japanese-American relations have unfortunately been such as to cause considerable concern on both sides of the Ocean. It is needed now, more than ever, to bring about a better understanding of each other's position in order to secure the interests and well-being of our two nations, thereby preserving the peace of the Pacific and maintaining the traditional friendship between us. ${ }^{1}$

With these words the new ambassador to the United States, Nomura Kichisaburō, greeted President Franklin D. Roosevelt on February 14, 1941. More than a year after the war in Europe had started, the political climate between Tokyo and Washington was deteriorating fast, and both sides knew it. Nomura, a retired admiral of the Imperial Navy who had served as foreign minister in the Abe cabinet, would hold negotiations with Roosevelt and his secretary of state, Cordell Hull, to find a formula for an understanding on Pacific and European affairs. Compared to Foreign Minister Matsuoka's negotiations in Moscow that resulted in the Neutrality Pact with Stalin, Nomura's aims in Washington were much broader, aimed at obtaining strategic objectives on several fronts. At the core of the initiative lay the desire for a negotiated settlement of Japan's imperial ambitions. They included US help in persuading Chiang Kai-shek's surrender in China, a new trade agreement with the United States, access to raw materials, the eventual neutralization of the Philippines, and principles of nonintervention in Europe. ${ }^{2}$ Naturally, such a wide-ranging "memorandum of understanding" was a Herculean task, considering that the United States was in the midst of abandoning its traditional neutrality toward Europe. Roosevelt enacted the Lend-Lease Act on March 11, 1941, and was already engaged in planning the post-World War II order with Great Britain, outlined in the Atlantic Charter of August 14. Neither was Nomura's task helped by the intransigent stance of Matsuoka, who rejected substantial concessions to the Americans, arguing for negotiations from a position of strength. ${ }^{3}$ But after Germany's attack on the USSR, on June 22, Matsuoka's approach lost rapidly in popularity among the cabinet. Only a month later, on July 18 , the government was

DOI: $10.4324 / 9781003182061-6$ 


\section{Fully engaged}

reshuffled yet again. With the approval of the Emperor, the army, and the navy, Konoe Fumimaro dissolved the cabinet just to form it anew with mostly the same members, save Matsuoka, who was replaced by Admiral Toyoda Teijirō. It was a peculiar political maneuver. Never before had a Japanese Prime Minister directly succeeded himself. The whole reshuffle was only necessary to dismiss the impulsive and Germanophile foreign minister without signaling an American-friendly turn, which in fact, it was. ${ }^{4}$ Konoe hoped to achieve more in his negotiations with the United States through a new direction at the Gaimushō.

Unfortunately, the new cabinet did not have more success with Washington. To avoid the semblance of weakness, the new foreign minister declared that his tenure would not break with the goals of his predecessor. At the same time, the relentless pressure of the Japanese army in Indochina against the French also signaled no shift in Japan's position. In meetings with Ambassadors Grew and Craigie in Tokyo, Foreign Minister Toyoda was conciliatory, assuring the American and British representatives of Japan's benign intentions in Southeast Asia. But neither Washington nor London thought this was much more than lip service. ${ }^{5}$ On July 26, Roosevelt froze Japanese assets in the United States. Toyoda's efforts toward Ambassador Grew did not pay off, nor did the overtures of Prime Minister Konoe for a summit meeting with President Roosevelt. The Americans did not buy into the Japanese narrative. On August 1, Roosevelt extended the sanctions to include an oil embargo, which was a particularly sensitive point to Tokyo as 80 percent of its oil was coming from the United States and its reserves would not last for much more than two years. Oil was the Achilles heel of the Japanese Empire.

On September 4, Envoy Widar Bagge telegraphed a highly pessimistic account to Stockholm, calling Grew's hopes for a solution without a military confrontation "utopian." Even though Bagge recognized Konoe's last-minute stunt to broker an understanding with Washington, he viewed the unwavering demand of the military for a "New Order" in East Asia as incompatible with US foreign policy. His observations were not mistaken. Only two days later, at a secret imperial conference, the use of force against the United States was decided should Nomura's talks fail to produce results. Shortly thereafter, Hull declined Toyoda's offer for a summit meeting. Within a month, Konoe's options were exhausted, leading to his resignation on October 16. He was succeeded by the former war minister and active-duty general, Tōjō Hideki, a hardliner with little sympathy for diplomatic overtures. In the evening hours of December 8, 1941, Bagge sent a short telegram to Stockholm: "the Japanese foreign ministry has officially notified the legation about the state of war between Japan, the USA, Great Britain, and the British dominions." In the morning hours Japan had attacked Pearl Harbor.

\section{National politics}

\section{No more debates}

News of the unprovoked attack and the following chain reaction-a wave of declarations of war-led, once again, to strong reactions in the Swedish press. 
Left-wing publications almost unisono interpreted Japan's move as another aggression but this time one that would spell the Empire's end. Norrskensflamman, the main paper of the Communist Party, even wrote polemically that Japan "will not survive this adventure. The samurai are on their way to commit harakiri." The Social-Demokraten similarly predicted that Japan's inferior naval forces could only outmaneuver the Anglo-Saxon navies in the short run, but that the attack was, overall, a "desperate move." The conservative Svenska Dagbladet, too, believed that this was foolish (although not unexpected) and that in contrast to the Russo-Japanese War of 1905, this war would turn out completely different, since Dagbladet viewed the United States as undefeatable. ${ }^{10}$ Also the liberal Göteborgs Handels- och Sjöfartstidning believed that the only chance of success for Japan was through a quick series of victories, as a protracted war would be unwinnable. ${ }^{11}$ The only paper that expressed a faint shimmer of optimism for Japan was the strongly German-friendly Aftonbladet, which framed the attack as the result of misguided US policy and that no one could know the outcome of the war but that it would be a chance to eliminate the "Russian peril" from Europe. That was not much more than wishful thinking as the Japanese had now clearly decided to fight the United States, not the USSR. In fact, Tokyo and Moscow would remain neutral toward each other's wars until August, 1945.

Most newspapers noted that this was the beginning of a true world war as the implications of the attack reverberated immediately to Europe, where the other Axis Powers declared war on the United States and vice versa. Swedish commentators tried to estimate what the impact of the monumental event would be for their country, but only a few of them mentioned Sweden's direct interests like the trading companies. Most analysts tried to estimate the secondary impact in terms of the shift in the balance of power in Europe, where now a new reality with direct US involvement would begin. Also, the tone and aim of these publications stand in contrast to those of earlier events-the outbreak of hostilities in China in 1931 and again in 1937, when editorials were still asking about what Sweden could or should do. The idea of a boycott movement, or the calls for Swedish condemnation, or action at the League were, as we have seen, actively discussed back then. In 1941, demands for Swedish involvement in the management of the crisis were ominously absent from the papers. Commentators and readers seem to have come to the conclusion that world events in Asia were now clearly beyond the reach of Sweden. Consequently, the most prominent call to action was that for a more robust Swedish neutrality. ${ }^{12}$

Politically, interest in Asian affairs was on an all-time low in Stockholm. So much so that the Utrikesutskottet, the Foreign Policy Committee (UU), barely took note of the new war. Far Eastern matters were discussed for only few minutes and solely in the context of what the situation meant for trade and Sweden's role as a Protecting Power. It was mostly Foreign Minister Günther informing parliament of a few facts on the ground. Neither during its meeting on December 9, 1941, nor on February 17, 1942, did the UU discuss Swedish reactions to the new theater of war, it merely took note of the entry of more belligerents into an already catastrophic situation. ${ }^{13}$ This absence of a debate about Japan also had 
structural reasons. In a situation where four out of five political parties were in the government, parliamentary power was weak. During 1941-1943 neither the UU nor the Advisory Council of Foreign Affairs were convoked often. Nevertheless, as a way of contrast a comparison with a "real" security threat is instructive. In the UU protocol of February 1942, Germany is mentioned on 180 pages, while Japan appears only nine times. Also the Riksdag debate of the same day did not include talks about Japan or the new War in the Pacific, in a meaningful way. The only mention of Japan was in the context of what kind of weaponry the Empire had used, and which of them seemed to be effective in air-battles. The expansion of World War II to dozens of new countries was to no practical concern of Swedish law makers. It was the national situation and European developments that occupied the legislature. ${ }^{14}$ Also in 1943, Japan was discussed only on the margins, as on November 3, when it was briefly mentioned that the Empire controlled the bulk of world rubber exports. ${ }^{15}$ On a national level, Japan had become a footnote to Sweden's foreign policy debate.

The marginalization of East Asian affairs is no surprise, since the situation in Scandinavia was bleak. Germany had occupied Denmark and Norway. Finland had joined the German invasion of the Soviet Union, and Iceland was under British control. Public debate in Sweden was still muffled, daily necessities were rationed, and many men had been drafted to the military to guard the borders. In this situation it was not Japan but national security that was naturally the top priority of the early 1940s. Intelligence, for example, became essential, but genuine Swedish intelligence services had only been formed in 1938-unknown to the public until 1943. The military intelligence, the so-called Section $U$, was headed by Colonel Carlos Adlercreutz-problematically a man with close relations to the military attachés of the Axis Powers. The second organization was the Allmänna Säkerhetstjänsten, the General Security Service, which enjoyed extensive powers. Over a few years, it opened 50 million private letters and wiretapped 11 million telephone calls. Thus, culminated the period of national alert (beredskapsaren). ${ }^{16}$ That was also no coincidence, as Stockholm had come to play a role as a meeting place for spies and secret missions of foreign powers. On neutral soil it was not only possible to collect and exchange sensitive information, but all belligerents also disseminated their propaganda-even Chinese and Japanese newsletters were distributed to a handful of concerned Swedes. ${ }^{17}$

After el-Alamein and Stalingrad it was evident that the war had reached a turning point. This was soon mirrored in official Swedish policy. Late in 1942, Colonel Adlercreutz was replaced and the police headquarters began to receive Danish, Norwegian, and Anglo-Saxon guests, in contrast to earlier days when German police officials had been in the majority. In the summer of 1943, the government in Stockholm finally announced that German soldiers would not be allowed to cross Swedish territory on their way home from Norway anymore. From now on, Swedish neutrality policy tilted in favor of the Allies. In October 1944, all exports of ball bearings to the German Reich were suspended-although ball-bearing steel was still sold. ${ }^{18}$ Swedish immigration policy, too, became more lenient. In a humanitarian action in October 1943, Sweden received more than 7,000 Danish 
Jews, shortly before their planned deportation to Germany. Even more spectacular was an agreement that Folke Bernadotte reached with Heinrich Himmler, under which a large number of concentration camp inmates could be evacuated to Sweden. That happened in parallel to the most well-known Swedish wartime effort to rescue Jews, achieved in Budapest by Raoul Wallenberg, the grandson of Sweden's first envoy to Japan. He worked for the American War Refugee Board but was subsequently arrested by the Red Army and never returned from internment. ${ }^{19}$ A similar fate awaited the hundreds of Baltic and German ex-soldiers who had escaped to Sweden by boat. The Hansson government extradited them to the Soviet Union. That sparked a furious moral debate in the newspapers, but it took until 1994 before the Swedish Government officially apologized to the last Baltic survivors. ${ }^{20}$

\section{Diplomacy}

\section{Sweden as a Protecting Power}

In contrast to the small impact that Pearl Harbor had on political discussions in Stockholm, it had an immediate effect on the UD-especially on its diplomats. The war in Europe, coupled with Sweden's neutrality and its diplomatic capacity with legations and consulates in most countries and territories of the world, had already led to a number of requests for Sweden's so-called Good Offices. The institution of Good Office was (and still is) a diplomatic practice in which one state lends its civil administrative capacity to another state. Good Office services can be rendered for different reasons, but especially when nations break relations, it is common that both ask third states to help them in civil matters toward the state with which direct relations are terminated. ${ }^{21}$ The reason for that is simple: even during intense conflicts (like wars) there are moments when enemies have common interests that can be resolved through negotiation. But to do so, they need intermediaries. The protection of citizens on enemy soil, the repatriation of diplomats and civilians, or the care for prisoners of war (POWs) are examples for shared belligerent interests. For instance, in the case of Japan, British, American, Dutch, and other enemy diplomats were immediately interned in their embassies and were in need of help to communicate and, eventually, return to their home countries. Simultaneously, the same was true for Japanese diplomats like Ambassador Nomura in the United States. The country rendering Good Office services is then also referred to as a "Protecting Power." Two aspects are important to note on this issue: firstly, Good Office/Protecting Power services are rendered with the full knowledge of both parties. This is only natural because the receiving state has to consent to the representative function of the third state. Usually, this is not a problem as all belligerent states want their interests protected and therefore grant the same treatment to their enemies. Reciprocity in diplomacy is a basic principle that is adhered to even during war. Consequently, Sweden did not commit an unfriendly act when assisting a state on the territory of its enemy. Secondly, Sweden did not become a part of the diplomacy of the 
protected state and did not commit an unneutral act by doing so. Sweden only took over clerical functions toward the citizens of the states it protected but did not itself become part of a foreign government's diplomacy, even when Sweden transmitted messages and notes between the two enemy states.

Sweden already had had some experience in handling requests for its Good Offices. In the nineteenth century it did so once, protecting Sardinian-Italian interests in Austria (1859-1866), and during World War I, Stockholm first safeguarded Bulgaria's interests in Great Britain from 1915 onward and later accepted 16 more Protecting Power mandates. Among those were the protection of Chinese interests in German-occupied Belgium and Japanese interests in Russia. ${ }^{22}$ Therefore, Sweden was a well-established and well-prepared Protecting Power when the war in Europe started. One week after Germany attacked Poland, the UD created an office which was tasked exclusively with handling Protecting Power mandates under the name Section B. The activities of the B-Section were referred to as the "representation of foreign interests." For example, Sweden was immediately asked to become the Protecting Power for Poland and South Africa in the German Reich, and for Germany in France and Egypt. In diplomatic parlance, Sweden "represented the interests" of these countries in the respective enemy territories.

With the spread of war, Swedish engagements as Protecting Power also grew. At its busiest, the Section B employed 20 people in Stockholm and approximately 150 people abroad at the legations and consulates. Sweden's administrative capacity was crucial for the orderly execution of the mandates. In 1943 alone, the Section B received and sent about 15,000 documents and telegrams and used up a budget of SEK 5 million. ${ }^{23}$ However, it needs to be stressed that Protecting Power mandates also had a formalistic side. In some instances, belligerents appointed a Protecting Power in territories where they had little to no interests, as a pro-forma arrangement, which resulted in little work for the Protecting Power. On the other hand, there were also instances when political

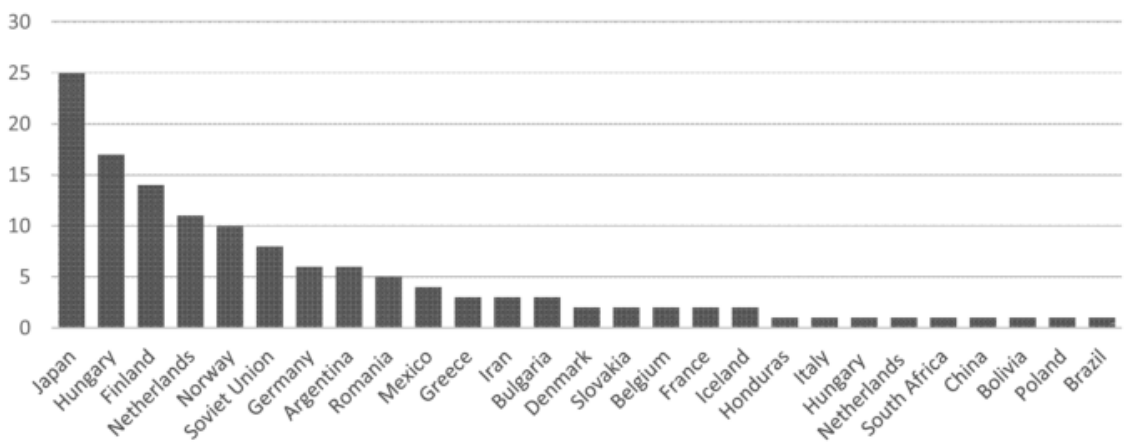

Figure 6.1 Number of Swedish Protecting Power mandates for country 1939-1945. Source: Lists in UDA, 2210.03.1, P19, A. See appendix. 
issues prevented Sweden from becoming a Protecting Power officially but when its diplomats were still able to help foreign citizens. The Section B referred to such cases as "informal" or "de-facto" mandates (underhandsuppdrag). For example, because Japan often refused to accord diplomatic rights to occupied countries, it did not recognize Sweden as the representative of Norwegian and Greek interests when their governments in exile approached Stockholm for help in Japan. At the same time, however, the Gaimushō did not object to the Swedish legation functioning as a point of contact for Norwegians and Greek subjects in Japan and protect them de facto. Bagge also initiated requests at the UD whether and how to help Norwegians in Hong Kong when it became clear that the Gaimushō had refused Argentina as Norway's Protecting Power there (in April 1942). ${ }^{24}$ Also Luxembourgian subjects were among the ones the consulate checked on regularly, starting from July 1942. ${ }^{25}$ The nonrecognition of enemy governments in

Table 6.1 Countries/Territories in which Sweden represented Japanese interests

\begin{tabular}{|c|c|}
\hline Name & Date \\
\hline Netherlands & $1941-12-12$ \\
\hline Hawaii $^{\mathrm{a}}$ & $1941-12-12$ \\
\hline India & $1941-12-12$ \\
\hline Burma & $1941-12-12$ \\
\hline Ceylon & $1941-12-12$ \\
\hline South Africa & $1941-12-12$ \\
\hline Chile & 1943-01-29 \\
\hline Belgium & 1944-06-10 \\
\hline Finland & 1944-09-30 \\
\hline Romania & $1944-11-17$ \\
\hline Bulgaria & $1944-11-24$ \\
\hline Iran & 1945-01-19 \\
\hline Iraq & 1945-01-19 \\
\hline Turkey & 1945-01-19 \\
\hline Bolivia & 1945-05-04 \\
\hline Brazil & 1945-05-04 \\
\hline Costa Rica & 1945-05-04 \\
\hline Lebanon $^{\mathrm{b}}$ & 1945-05-04 \\
\hline Nicaragua & 1945-05-04 \\
\hline Paraguay & 1945-05-04 \\
\hline Peru & 1945-05-04 \\
\hline Uruguay & 1945-05-04 \\
\hline Denmark & 1945-06-29 \\
\hline Mexico & 1945-06-29 \\
\hline Switzerland & 1945-11-02 \\
\hline
\end{tabular}

Source: Lists in UDA, 2210.03.1, P19, A. See appendix.

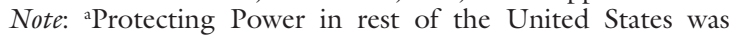
Spain. ${ }^{b}$ French mandate of Lebanon and Syria. 
Table 6.2 Countries whose interests Sweden represented in Japan

\begin{tabular}{ll}
\hline Name & Date \\
\hline Netherlands & $1941-12-12$ \\
Belgium & $1941-12-12$ \\
Bolivia & $1942-02-06$ \\
Mexico & $1941-12-12$ \\
Norway $^{\mathrm{a}}$ & $1942-03$ \\
Honduras $_{\text {Greece }}^{\mathrm{a}}$ & $1942-04-17$ \\
Argentina & $1942-08$ \\
Denmark & $1944-01-28$ \\
Finland & $1944-05-25$ \\
Romania & $1944-09-29$ \\
Bulgaria & $1944-11-17$ \\
Italy & $1944-11-24$ \\
\hline
\end{tabular}

Source: Lists in UDA, 2210.03.1, P19, A. See appendix. Note: ${ }^{a}$ De facto mandates.

exile was primarily meant to delegitimize those governments. It was not followed consistently, however. Japan did accept Sweden's representation of the interests of the Dutch Government in exile, which probably had to do with the relatively important status of the Dutch East Indies, where Japan had sought the protection of its interests by Switzerland.

Sweden accepted Protecting Power mandates both formally and informally, leading to a total of 135 mandates between 1939 and $1945 .{ }^{26}$ Roughly a third of these mandates were directly or indirectly the consequence of Japan's entry into the war. ${ }^{27}$ In addition, Japan was the country for which Sweden held the most Protecting Power mandates. Stockholm accepted 25 mandates for Japan, as can be seen in Figure 6.1 and Table 6.1. Vice-versa, Japan was also the country in which Sweden protected most foreign interests, with a total of 13 mandates (Table 6.2). ${ }^{28}$

\section{Protecting Japan-and her enemies}

On December 10, the Gaimushō handed the Swedish legation in Tokyo a list of territories where it wished to receive Swedish protection of Japanese interests. They included the possessions of the British Empire in East and Southeast Asia: Burma, Ceylon, and the northwestern parts of India (Baluchistan, Punjab, and Kashmir), ${ }^{29}$ but also the US islands of Hawaii. That was a peculiar request since Japan had turned to Spain for its representation on the US mainland. The reason for the exception in Hawaii was one of practicality because Spain did not operate a consulate there, but the islands were home to over 400,000 people of Japanese 
descent. That was more than a third of the Hawaiian population. ${ }^{30}$ Many of them were already second or third generation emigrants who felt more Hawaiian than Japanese but for others, the ties to Japan were still intact. Japan also had a large consulate in Honolulu, infamously staffed with several spies who had sent information about Pearl Harbor's military base to the Japanese Navy. ${ }^{31}$ Those were important reasons to have a genuine and effective Protecting Power on the island with the capacity and willingness to intervene on behalf of Japan. Sweden was a natural choice for that, since it had been operating an honorary consulate there since the 1850s. By 1941, the unsalaried position was filled by a US-Swedish dual national, Gustaf Wilhelm Olson. Having emigrated to the United States in 1888 , and worked for hospitals and hospital associations for decades, Olson was 65 years old at the time of his appointment and well qualified especially for the humanitarian aspect of the work for Japanese internees. ${ }^{32}$

Protecting Power mandates can be confusing. In the case of US-Japanese relations and the neutral go-betweens, one more factor complicated the situation, because belligerents did not have to ask the same neutral state to serve as their common Protecting Power. Japan was represented by Spain in the United States but since Washington did not trust Francoist Spain, it asked Switzerland to do the same job in Tokyo. That meant that Sweden was the third neutral involved in US-Japanese wartime diplomacy, responsible only for Japan's interests in Hawaii. This had implications on a topic that immediately appeared on the records of the legation: the question of how to evacuate the diplomats and civilians of the Empire's new enemies who were now so unfortunately stranded in Japan. Already by the beginning of January 1942, the Swiss announced a plan to organize a prisoner exchange on the neutral territory of LourençoMarques (Maputo), the capital of Portuguese Mozambique at the southeastern coast of Africa. The largest stakeholders in this civilian exchange program were the United States, Great Britain, and Japan, because they had the most people on each other's soil. Since Sweden was Japan's Protecting Power in Hawaii, it had to join the negotiating table. In addition, the decision of Washington and London to coordinate their efforts for exchanges added another layer of difficulty because Britain's Protecting Power in Japan was Argentina at the time (London switched to Switzerland only in May 1942). Adding four neutrals to the discussions between three belligerents meant the involvement of seven governments in highly sensitive negotiations. It was a confusing situation with a lot of potential for misunderstanding. ${ }^{33}$ Minister Bagge had to coordinate on a daily basis with his Swiss and Argentinian counterparts to drive the discussion on the exchanges forward. ${ }^{34}$ The only thing he could do to simplify the situation was to make sure that Sweden left all the sensitive negotiation to the main Protecting Powers. He held that "although Sweden protects Japanese interests in Hawaii, the principles of the evacuation must be prepared through Swiss mediation." 35 Switzerland was leading the negotiations in Tokyo and Bagge followed them closely. Over the next year, the Swedish legation cabled regular information on the state of evacuation ships and the negotiations between the United States and Japan back to the UD. 


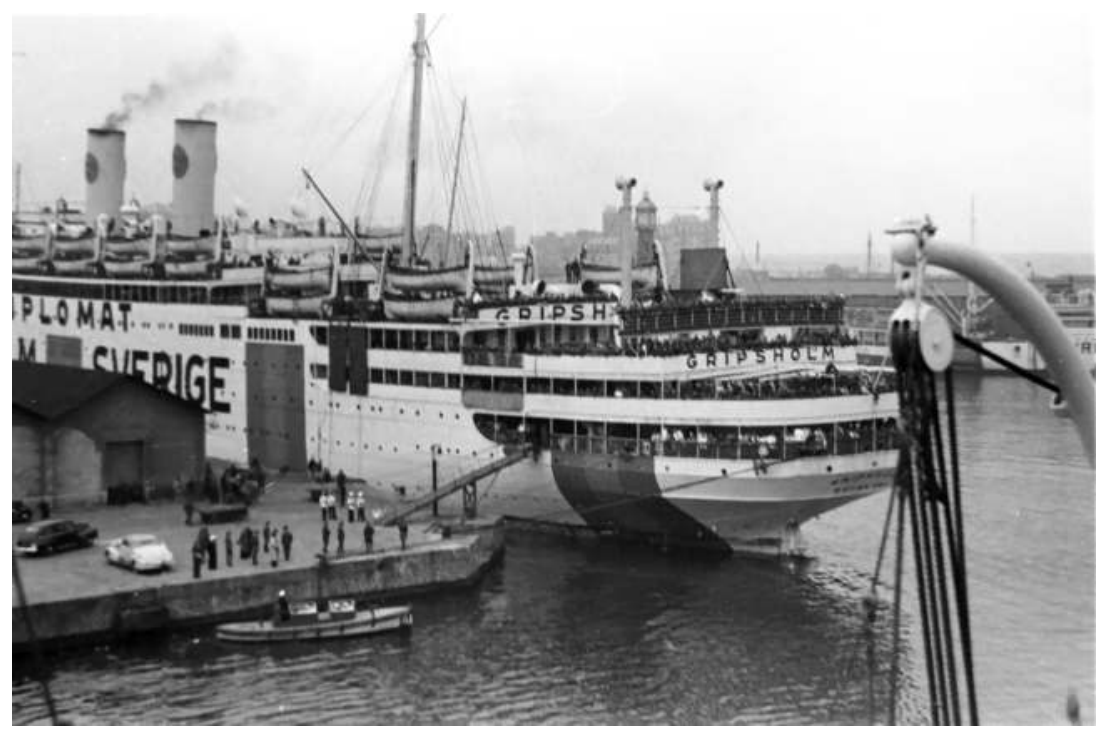

Picture 6.1 The Gripsholm anchoring in Barcelona. Source: ICRCAA, V-PHIST-00985-22. 1944. International Committee of the Red Cross, "War 1939-1945." Barcelona. German-allied exchange. Departure of the hospital ship "Gradisca" which passes near the Swedish boat "Gripsholm" having in its board British and American prisoners."

A particularly important issue that was handled by Stockholm was the provision of ships. Because Switzerland had only few ships sailing under its flag and none of them big enough to accommodate the more than 1,000 passengers that the exchange plans envisioned, the Swedes organized a cruiser of theirs-the Gripsholm. The splendid ship was painted in the colors of the Red Cross to signal to all submarines and war ships that it was a hospital ship under international diplomatic protection.

In Tokyo, Minister Bagge started working immediately on the interests of the nationals under his protection. The Dutch were the first to solicit Sweden's help after their government in exile had declared war on Japan alongside the United States and Britain. Like the Anglo-American embassies also the legation of the Netherlands was sealed off and its diplomats were made prisoners in their homes. Bagge was able to speak to the Dutch minister on December 10 and transmit information about the meeting via Stockholm to the government in exile. A day later, the Swedish legation forwarded the first telegram of Belgian Ambassador Forthomme to Stockholm since his Foreign Ministry (also in exile) had decided to break diplomatic relations with Japan-one step short of declaring war. The same was true for the Norwegian and the Mexican legations. Their governments broke relations on December 9, which for their diplomatic missions in Tokyo meant becoming subject to the same treatment as the missions of those states who had 
declared war. The Japanese Military Police, the Kenpeitai, refused to differentiate between enemy states and nations without diplomatic contact. Communication with their governments was interrupted and their buildings were isolated. ${ }^{36}$

Over the course of a few days, the Swedish legation took over also the protection of nationals from Belgium, Bolivia, Honduras, and Mexico. Bagge was allowed to visit the heads of the missions that were under his protection but only occasionally-much less than he would have wanted. He protested the restrictions at the Gaimushō, but often to little avail as even the Gaimushō was not always able to alter the behavior of the Kenpeitai. This was all the more reason to evacuate enemy diplomats and civilians as soon as possible. After months of negotiations, Bagge's American protégés from Bolivia, Honduras, and Mexico were included in the first exchange ship to the United States, and the Europeans from Belgium, the Netherlands, Norway, and Greece were on the second ship for the British exchange a few days later. British Ambassador Craigie, who was in the second batch of evacuees, recalls in his memoirs distinctively the joy of meeting again the colleagues with whom no contact had been possible for nearly eight months. ${ }^{37}$ To alert potential evacuees of the possibility to be repatriated, the legation posted several notices in Japanese newspapers. An example of such a notice is the following extract from the Japan Times of May 25, 1942 (Picture 6.2).

\title{
THE SWEDISH LECATION
}

\author{
being in charge of the interests in Japan of
}

\section{BELCIUM \\ BOLIVIA \\ HONDURAS \\ MEXICO and \\ THE NETHERLANDS}

desires to inform nationals of these countries, who maty wish to be included in the forthcoming evacuation and who have no: already made known their intention in this respect. that applications should be sent in as soon as possible either directly to the Swedish Legation or to the Swedish Consulate in Kobe.

\section{W. BACGE \\ Swedish Minister}

Swedish Legation, 22 Nishimachi, Azabu-ku, Tokyo.

Swedish Consulate, 93 Yedo-machi, Kobe.

Picture 6.2 Evacuation notice by the Swedish legation in the Japan Times. Source: Japan Times, May 25, 1942 (BA, 230033.2, F2b, I). Note: Posted by the Swedish legation to alert potential evacuees. 


\section{Fully engaged}

\section{New diplomats for Swedish jobs}

Literally overnight, the Swedish legation in Tokyo acquired a broad range of new responsibilities. To Minister Bagge, it was clear that this situation would result in a significant increase in the workload for his staff. Before the end of the year, he requested more diplomatic personnel—a Swedish diplomat from Moscow, if possible, as that person would be able to travel to Tokyo relatively quickly. Additionally, Bagge asked his ministry for a free hand in hiring local staff, Japanese or foreign. ${ }^{38}$ It was a reasonable request. The diplomatic correspondence between the legation and Stockholm became twice as extensive for the four years of the war. Compared to earlier days, when only one or two telegrams per week were exchanged between the legation and the UD, after December 7 , daily telegrams - often pertaining to several issues-became the norm. Already on December 11, Bagge hired two new (Swedish) consuls. Ivan Troedsson, a civil engineer, was appointed to the consular district of Yokohama and Tokyo, and Lorens Wirén, a businessman, became the successor of James in Kobe and Osaka. Troedsson, although named consul for Yokohama, had his workplace in the legation in Tokyo, not in the Yokohama consulate. The latter office was staffed with a new vice-consul in January 1942 - the Swedish national Nils Kallin. He had been one of the local directors of SKF and was only 35 years old at the time of his appointment. ${ }^{39}$ He took over the entire administrative affairs of the consulate, that is, the dossiers that Guston (and others) had been working on before him. ${ }^{40}$ However, the content of his work was drastically different from that of his predecessors. The multiplication of all the humanitarian and legal cases he had to deal with increased communications from the consulate to the legation from a few letters each month to daily correspondence with Bagge. Kallin's workload was soon too much for one person, which prompted Bagge to expand the mission staff through administrative positions. In May 1942, he appointed Gunnar Wester, also a Swedish national, to support the Yokohama consulate as a secretary. ${ }^{41}$ The minister also hired new legation staff. On January 1, 1942, Mr A. Olofson, another Swede, entered the service. Between February and April two more Swedes joined Bagge's staff. First Ulf Wendbladh and then Nils E. Ericson, the representative of Carl Ekman \& Co., whom Bagge had known and worked with for many years. The legation also hired a Japanese typist (Mrs Uchiyama), an errand boy (K. Oyama), and a chauffeur (K. Kawahara). Together with Ericson and Wendbladh, they were assigned to work in the newly established Section B of the legation, which mirrored the Section B at the UD. ${ }^{42}$ The only person who was removed from his position was a Japanese interpreter, Mr Kokubu, whom Bagge reported was "undoubtedly working as a special agent of the police (...)."43 Bagge knew that this was nothing extraordinary and happened in other legations too, but the circumstances compelled him to replace the employee with a new interpreter, Mr Hashimoto.

What stands out regarding the new arrivals at the legation is that almost exclusively Swedish and Japanese nationals were taken in. The times when honorary consuls with a different nationality could be contracted were over. Only a 
Swedish passport could guarantee some recognition by Japanese military and civilian personnel. That is not to say, though, that Bagge did not try to extend the diplomatic umbrella to other nationals. There were cases in which he tried to hire people into his services to protect them from repercussions. Mr George-Adis was the earliest example of that tactic. George-Adis had been living in Yokohama for nearly two decades but did not have a valid passport that could certify his nationality. He claimed to be Greek but since he spent his youth in Romania, the Greek legation did not believe him and refused him a passport, making him effectively stateless. ${ }^{44}$ After Bagge had failed to convince the Greek minister to recognize George-Adis, he tried to hire the unlucky man into his legation under the highly dubious pretext that he was in need of an interpreter for Greek-English translations-never mind that the Swedish legation was not in charge of Greek interests. The military authorities denied the request. ${ }^{45}$ Bagge was, however, able to hire other foreigners. A Danish national, Mr E.F. Johansen was working for the legation until mid-May 1945, when he was arrested by the Japanese police after Denmark had been liberated by the Allies from the German occupation. ${ }^{46}$ Also a Portuguese citizen was in Bagge's service, Mr R. da Silva, as well as a Korean office boy. ${ }^{47}$ By May 1943, 18 months after Pearl Harbor, the mission staff had grown to 20 people, out of which 11 were Swedes. But even that was not enough. Bagge requested to receive at least one more official from Sweden to support the career diplomats in Tokyo. The UD proposed to send a senior official to take over the Section B. However, by that time, Bagge had already given this position to Ericson, whom he judged to be perfectly equipped for the task because he had been living in Japan for 20 years and spoke Japanese fluently. Those qualities, Bagge insisted, were absolutely necessary for the head of the Section B whose duties consisted of regular POW-camp visits and delicate negotiations with local Japanese civilian and military officers. The pragmatic solution to the problem was to convert Ericson into a full-fledged diplomat. Bagge requested a diplomatic passport for him, through which Ericson became a legation secretary. ${ }^{48}$

\section{New jobs for Swedish diplomats}

There were many instances when Bagge's advocacy for his protégés clashed with Japanese authorities. To be fair, however, it must be said that the outbreak of the war with the Allied Powers caused a considerable amount of confusion also among Japanese agencies. The question of how to proceed with Protecting Powers who represented enemy interests had probably not been studied ahead of the war. It took the Gaimushō three months to release official guidelines pertaining to the rights and duties of Protecting Powers. Japan promised therein to adhere to common practices, granting diplomatic representatives (agents of embassies, legations, or consulates) the following rights:

1. Visit the diplomatic personnel of the represented country.

2. Take over the buildings, archives, and the furniture of the Protected Power. 


\section{Fully engaged}

3. Assist the diplomats of the Protected Power in matters concerning their private life.

4. Inquire about the status of enemy civilians, including interned or arrested subjects.

5. Manage financial affairs of the Protected Power, including that of interned and arrested subjects. ${ }^{49}$

All five clauses were accompanied by the condition that, in accordance with international law, the Gaimushō and concerned Japanese agencies had to be informed before any of these steps were taken and that permissions by them had to be granted beforehand. ${ }^{50}$ The regulations clarified much. For example, that the property of enemy legations remained in their possession-despite the state of war. Enemy buildings, real estate, and bank accounts were not seized by Japanese forces, only sealed off for the time of the war. Bagge was, therefore, also charged with the caretaking of foreign assets. Bank accounts were often not released for his use but the private funds of diplomats and the cash that legations and consulates held on their premises could mostly be transferred to the Swedish legation. Bagge kept accounts for the countries under his protection and credited them whenever financial assets of theirs could be secured.

The protection of buildings was more difficult. In the beginning the stranded enemy diplomats took care of their own premises because they were interned therein but after the evacuations in summer 1942, Bagge had to find other solutions. First, he arranged for the former Japanese staff of the defunct diplomatic missions to occupy and take care of the buildings. But especially for the Dutch legation, this arrangement did not work well. Bagge, therefore, moved his own staff into the Dutch buildings with von Sydow and Ericson designated to live there. Physical presence was the best form of protection. ${ }^{51}$

In a similar way, visits to POW camps became an important part of the Swedish mandate in Japan which, according to the regulations, could only be accomplished by Swedish nationals with diplomatic status. From February 1942 onward, representatives of Bagge's legation visited internment camps roughly three to four times a month. The most visited site was the Den'nenchōfu camp near Tokyo, but also the camps in Urawa (also near Tokyo), Nagasaki, Kogane, and Kobe were visited frequently. Nils Ericson, the head of the Section B, and Consul Troedsson were most often in charge of the inspections. They were supported by Consul Wirén and the secretaries Gawell and von Sydow, and sometimes also directly by Minister Bagge. After all visits, reports were written about the situation in the camps. Three examples of 1942 are reproduced in the appendix of this book. Over the course of the first 16 months, the Swedes made about 50 camp visits. ${ }^{52}$ Considering that Japan was running hundreds of POW camps and prisons in the country, the visits were not as plentiful or extensive as they would have needed to be to provide a comprehensive assessment of the situation of all POWs. In addition, the Gaimushō did not concede to neutral inspections of camps outside Japan proper (with few exceptions). Requests for visits to the Changi internment camp in occupied Singapore, for example, were 
quickly denied. ${ }^{53}$ A regulatory gray area were the camps located in the overseas territories of the Japanese Empire-that is the territories that were part of the Japanese Empire already before the outbreak of hostilities on the continent. Camps in Formosa (Taiwan) were one example, the other was civilian internees on the Kwantung Peninsula. Consul Kjellin, Sweden's representative in Dairen, reported that although he did not have an official mandate as part of the Swedish Protecting Power

(...) as I am one of the few neutral foreigners living here, I have considered it a humanitarian duty to try to assist the British citizens interned here in different ways and to help them with food, tobacco, etc. The local authorities have also been accommodating in this respect and given me permission to visit the interned persons. ${ }^{54}$

Some limited impact outside Japan was possible, but certainly only with the benevolent consent of local Japanese authorities. It is also unclear how long such unofficial activities could be sustained. Beyond this one letter from Kjellin, there are no more reports pertaining to the situation of interned foreigners in Dairen.

Beyond diplomats and POWs, the legation's new responsibilities extended also to the caretaking of enemy civilians. The first such case pertained to seven Dutch businessmen in Kobe who, right after the outbreak of the war, were arrested and imprisoned. They were directors of trading companies or bank managers. Like their British colleagues, a year earlier they were accused of espionage, a charge that allowed Japanese authorities to imprison subjects indefinitely and without trial. Bagge reported that the charges were "in my opinion, only pretext, the real purpose is to take hostages." 55 The best that he could do was to launch repeated complaints toward the Gaimushō and try to evacuate these civilians through the exchange ships as soon as possible. In the meantime, he would look after their physical well-being for as long as their confinement lasted.

These jobs were new and incomparable to the time before Pearl Harbor when the legation was working almost exclusively on economic questions. The contrast was also felt in the consulates. The work of the consuls in Yokohama used to consist mainly of granting visas, indexing Swedish trade at the ports, and assisting Swedes in case of illness or accidents. But by 1942, the new vice-consul in Yokohama, Kallin, was suddenly ordered to take care of the Dutch, Belgian, Mexican, and later also the Bolivian consulates in his district. Bagge instructed him to secure the consular archives and their belongings and report about the treatment of the former consuls. Kallin also started visiting the Negishi internment camp as soon as February 25. Dutch and Belgian nationals were imprisoned there and needed the help of their diplomatic representative to pass messages to their home governments and families or to request better treatment in case of illness or financial hardship. ${ }^{56}$ Kallin made regular cash payments to the foreign nationals (interned or free) under his care to allow them to buy food and clothes for the winter months-even in an internment camp one still needed money. 
Soon, Kallin also started filing legal claims toward the Japanese authorities in the name of the people and companies he represented. In late March, he intervened in the name of the Dutch "Japan-China Trading Company" against the capture and sale of a steamship that was seized in the port of Yokohama when the war broke out. ${ }^{57}$ Captured civilian enemy vessels were subject to confiscation and liquidation by Japanese prize-courts. Kallin and his boss Troedsson helped in such cases the defendants to protect their property-even if the chances of success were scant..$^{58}$

In short, the jobs of the entire Swedish mission had become exceedingly diverse. Bagge and his staff became heavily involved in issues of other nations while, at the same time, Swedish diplomats at home and abroad lent their Good Offices to Japan. That was not self-evident- the UD could have rejected the requests of either side. But Bagge and UD decided that a refusal to serve as Protecting Power was not a suitable course of action. In one of the first telegrams to Stockholm, after the attack on Pearl Harbor, Bagge explicitly recommended to the UD that Sweden should accept the responsibilities for Japan since "the fulfillment of such tasks might result in benefits in other respects (...). ${ }^{\prime 59} \mathrm{He}$ was hopeful that the Japanese authorities would extend their goodwill to Sweden in matters of trade. His superiors seemed to have shared his opinion. None of Japan's requests was rejected.

\section{Swedish-Swiss collaboration and the Neutral Committee of the YMCA}

The closest diplomatic friend to the Swedish legation was the Swiss mission. Although they were not the only two neutral legations left in Tokyo-Argentina, Portugal, Spain, the USSR, Afghanistan, and the Vatican also still had diplomats in Japan-there are several episodes indicating that Bagge and his team collaborated particularly closely with the Swiss. Vice-Consul Kallin, for instance, wrote to Bagge in July 1942 that he recommended seeking out the opinion of the Swiss minister before advancing on a matter concerning Axis and neutral legations in Tokyo. The question was how neutral states among themselves should coordinate to achieve concessions from the Gaimushō. Kallin did not mention the Spanish, the Soviets, or any other neutral, only the Swiss seemed relevant to him to coordinate inter-neutral interest. ${ }^{60}$

A more important case was the collaboration of the Swedish and the Swiss legation to inspect POW camps in Formosa (Taiwan) in the fall of 1943. It was one of the few cases in which the Gaimushō sanctioned the inspection of camps outside the mainland. Because Formosa had been part of the Japanese Empire since 1895, the military permitted a joint Swedish-Swiss inspection of six POW internment camps there between September 21 and October 2, 1943. ${ }^{61}$ Why the visit was done by two representatives from different neutral countries is not clear. It might have had to do with the death of the Swiss delegate, Robert Bossert, who perished on a mission to Formosa a year earlier. ${ }^{62}$ Sending two diplomats might have been a security measure for the personnel. The collaboration seemed 
to have been fruitful on a different level. Ericson, head of the Section B, concluded in his final report that

[t]he arrangements for a joint visit by the Swiss and Swedish delegates seemed before our start somewhat dubious but I am now of the opinion that the advantages were many and that further visits to camps inside Japan Proper ought to be made jointly. No doubt the Swiss delegate who proved to (sic.) an experienced and valuable companion, and I are to a great extent able to supplement each others informations (sic.) and impressions. ${ }^{63}$

Evidently, the collaboration between the Swedish and the Swiss legations produced results. On the other hand, there was little alternative left. Japan's enemies used the Good Offices of either Sweden or Switzerland. They were the only possible partners. This point also transpires from the legations telegraphic records. In 1942, Bagge referred to the Swiss Government, the Swiss minister, and the Swiss legation on 22 separate instances. Spain, Portugal, and the Soviet Union were not mentioned a single time.$^{64}$ However, that does not mean that collaboration was a simple task for the two legations. On the contrary, joint initiatives had to be carefully planned and executed if they were to succeed since the political environment in Japan was highly suspicious of neutral interventions. The best example for the delicate situation was the way in which the legations had to deal with the Young Men's Christian Association (YMCA), the only other international humanitarian organization besides the International Committee of the Red Cross (ICRC) that was left in Japan.

The YMCA was founded in 1844 in London. It grew into a worldwide organization to promote Christian values and offer young men sports and mental health-related activities. ${ }^{65}$ A century later, it was well established and, like the ICRC, headquartered in Geneva. National committees existed all around the world, including Japan. In March 1942, the international YMCA contacted the Swedish legation to ask for their help in organizing relief work for POWs in Japan and the occupied territories. The legation, willing to assist, forwarded the request to the national Japanese YMCA, which was headed by Saitō Sōichi, a well-known public intellectual, devout second-generation Christian, and a strong supporter of peaceful relations with the United States. He was among the last delegates of the YMCA in the United States in 1941 and the second Japanese man to visit the United States again after the war in 1948. On the other hand, he also had a track record of defending Japanese actions in Manchukuo and criticized the international YMCA heavily for its siding with the League of Nations. Under his leadership, the Japanese YMCA withdrew from the international YMCA in 1941. ${ }^{66}$ His ambivalent nationalist stance proved to be a major hurdle for the success of the relief efforts initiated by the Geneva-based mother organization. A legation report on the issue stated that

lengthy discussions with the Ministry of Foreign Affairs and the military administration ensued and it gradually became evident that the Japanese 


\section{Fully engaged}

YMCA were not only helpless in the matter of dealing with the authorities, but also that they were more inclined, perhaps forced by the prevailing situation, to become active for benefit of the Japanese soldiers. ${ }^{67}$

Saitō had made such a bad impression on the legation that Bagge and his staff decided that to save the initiative, a neutral committee had to be formed to carry out the task. It was inaugurated on June 22, 1942, under the patronage of both the Swedish and the Swiss legations in the configuration seen in Table 6.3.

The actual work of the committee was handled by Ericson, since the staff who carried out the committee's missions was the Section B. ${ }^{68}$ Through this arrangement, the Section B gained a second identity as the Office of the "Neutral Committee of the YMCA." The Swiss stayed on the sidelines of this initiative. Although the Swiss envoy, Camille Gorgé, lent his name to the Neutral Committee, giving it a more international footing, he and his staff were scarcely involved in the actual work. Their only real collaboration happened through K. Bernath who, together with Ericson, formed the "working committee" to guide the actions. The absence of the Swiss minister and especially of the Swiss ICRC delegate, Fritz Paravicini, from the real work of the committee had two reasons. On the one hand, the Swiss were already deeply engaged in other relief actions through the ICRC. It, therefore, "seemed to be a reasonable and rational division of work, if the Swedish Legation undertook to assist the YMCA." ${ }^{69}$ In contrast to the ICRC, the Neutral Committee of the YMCA decided not to engage in any efforts relating to the treatment of POWs. On the contrary, to forestall negative reaction by the Japanese authorities and not to confuse the two mandates, the Neutral Committee of the YMCA explicitly decided not to check on the situation of POWs in the camps. They were only trying to deliver relief goods for the mental and physical recreation of the prisoners. They distributed books, sports gear, gardening tools, and musical instruments to POW camps, to allow the prisoners to engage in activities that would help ease the intense stress and deprivation that they were under. This was not only in line with YMCA goals but ensured that the

Table 6.3 Composition of the Neutral Committee of the YMCA

\begin{tabular}{lll}
\hline Name & Position & Function \\
\hline Widar Bagge & Swedish Minister & Chairman \\
Camille Gorgé & Swiss Minister & \\
F. Paravicini & Red Cross Delegate & \\
K. Bernath & Swiss Legation & \\
I.P. Troedsson & Swedish Consul & \\
N.E. Ericson & Swedish Legation & Secretary \\
\hline
\end{tabular}

Source: "Confidential Memorandum concerning the international YMCA activities in Japan," November 25, 1943 (BA, 230033.2, F2c, I). 
Neutral Committee would not duplicate the work of Paravicini and the ICRC, who oversaw the delivery of foodstuffs, medicine, and clothing. Secondly, the YMCA initiative came with a risk to other activities that the two legations had to carry out. The Swiss legation was especially sensitive to this, as it did not want to jeopardize its relationship with Japanese authorities. At the beginning of the YMCA initiative, when the military showed nothing but rejection and suspicion toward the committee's requests

the Swiss Legation appeared rather uneasy about the effects these negotiations might have on their work as a protective (sic.) power and for their work with the ICRC, and even felt it advisable to withdraw one of their members from the YMCA Neutral Committee, in order not to risk having his work among civilian internees impeded..$^{70}$

The Swiss had to be careful because their own mandates were already delicate. Supporting yet another initiative to help Japan's enemies by lending Swiss personnel would certainly seem even more objectionable to Japanese bureaucrats who did not trust neutral activities in the first place. After all, the fear of espionage and the distrust toward foreigners was at its absolute height in those years.

Only after some months the Neutral Committee achieved first successes, when the resistance of the Ministry of War to the distribution of relief goods started fading. Ericson was finally able to approach the War Prisoners Information Bureau and initiate confidence-building measures. Bagge's personal involvement in this phase was crucial. Through repeated dinner invitations of the Bureau's chief, Major General Hamada, he built the necessary trust to receive permits for his staff to visit POW camps and carry out the YMCA mandates. Nevertheless, difficulties always remained since even with Major Hamada's consent local authorities could block camp visits at the last minute. "The military authorities have had to be treated with the utmost discretion and at the least sign of disapproval a back out has had to be effected (sic.)." In In the end, the efforts and the great care with which the missions were carried out paid off to some extent. By the end of 1943, Ericson and Bernath reported that more than 16,000 books and magazines had been distributed; $¥ 25,000$ were spent on musical instruments; and roughly the same amount went to sports equipment, indoor games, and other recreational articles. To put these numbers in perspective: the highest-paid monthly salary for the Swedish staff working at the office of the Neutral Committee at the time was $¥ 800 .^{72}$

The Neutral Committee was also able to work in the other direction. Several thousand Japanese books were sent to Japanese internees in the United States and Canada, to support the YMCA relief efforts there. The committee also tried to expand its operations to other territories by soliciting the help of Swedes and Swiss outside the Japanese mainland. In Shanghai, the Swede Gustaf Asker was appointed local representative of the Neutral Committee. In Hong Kong, it was F. Kengelbacher, a Swiss, who accepted the position, and in Bangkok and Manila, Swedish consuls F. Enstedt and H. Janson did the same. Unfortunately, only the representative in Thailand could carry out concrete relief work in POW camps. 


\section{Fully engaged}

The others did not receive the consent of the local Japanese authorities to enter the camps, nor were they acknowledged as YMCA representatives. The impact of the international network of the Neutral Committee was, therefore, limited. ${ }^{73}$ Nevertheless, the episode demonstrates the willingness of the Swedish legation to utilize any possible chance to extend its humanitarian work beyond the narrow margins of mainland Japan.

\section{Japan's late appreciation for Swedish intelligence}

In Stockholm, diplomatic developments moved more slowly. The unsatisfactory situation with only one Japanese chargé d'affaires from the Gaimushō and one military attaché from the army continued well into 1942. Although the Swedish Government wished for a stronger Japanese representation, neither the UD nor Bagge had any leverage to move the Japanese side. The only thing Envoy Bagge could do was to keep mentioning the unfortunate situation whenever he met with high-ranking Japanese officials. It was only after a meeting with Prime Minister Tōjō Hideki, in late October 1942, that he finally met with serious interest in the reappointment of a senior diplomat. ${ }^{74}$ Okamoto Suemasa was named minister extraordinary and plenipotentiary to Sweden. He was the former general consul to Shanghai and had resided in Calcutta when the war with the Allies broke out. He was interned by the British authorities in India but came free in August through the very prisoner exchange program in Lourenço-Marques that the neutrals had organized. ${ }^{75}$ Okamoto was nominated envoy to Sweden by the Emperor on November 26, 1942, assuming his post the next month. ${ }^{76}$

This appointment was an interesting development because it coincided with the creation of the Ministry of Greater East Asia on November 1, 1942, which absorbed the Gaimushō's East Asia and South Sea Bureaus - a move that cut the Gaimushō's personnel in half and undermined its standing within the cabinet. That at this moment the diplomatic connection to Sweden was strengthened, is not self-evident. Whether the decision was based purely on Prime Minister Tōjō's intuition, or if it was part of an emerging strategy toward the European neutrals cannot be judged from the available sources. However, as time went by, the previous Japanese disdain for Stockholm turned into its opposite. The more the war in the Pacific and Europe deteriorated, the more personnel the Gaimushō, the army, the navy, and even the air force sent to the Scandinavian outpost. By early 1945, Sweden hosted 15 Japanese diplomats-a remarkable change compared to three years earlier.

With the arrival of Okamoto in late 1942, the Gaimushō started using Stockholm more proactively as an outpost for spying activities. Okamoto began sending intelligence reports back to Tokyo. In the beginning, they contained only his personal observations, generalities about the opinions of Swedes, and assessments about meetings he had with high-ranking officials like Gunnar Hägglöf, the head of the foreign trade section. ${ }^{77}$ However, over time, his assessments became more refined. The lack of adequate sources precludes a precise description of the nature of his contacts but what can be judged from the telegrams intercepted 
Table 6.4 Japanese diplomats in Sweden in 1945

\begin{tabular}{lll}
\hline Position & Name & Date Assigned \\
\hline Minister Plenipotentiary & Okamoto Suemasa & 1942 (Dec.) \\
Attaché & Satō Kazutoshi & 1942 \\
Attaché & Takeuchi Goichi & 1943 \\
Second leg. Secretary & Tsuchiya Jun & 1944 \\
Third leg. Secretary & Uryū Matao & 1944 \\
Third leg. Secretary & Hattori Gorō & 1944 \\
Attaché & Tō Ken'ichi & 1944 \\
Attaché & Andō Ryūichi & 1944 \\
Attaché & Abe Ken'ichi & 1944 \\
Military Attaché & Onodera Makoto & 1941 \\
Deputy Military Attaché & Itō Kiyokazu & 1944 \\
Deputy Military Attaché & Satō Tatsuya & 1944 \\
Deputy Military Attaché & Inaba Masaki & 1944 \\
Naval Attaché & Mishima Iori & 1942 \\
Deputy Air Attaché & Kigoshi Yasukazu & 1944
\end{tabular}

Source: Sweden. Vetenskapsakademin. "Sveriges Statskalender" [Sweden's State Calendar]. Uppsala och Stockholm, Almquist \& Wiksells Boktryckeri A.B., 1945, 68.

by US intelligence is that he used his acquaintance to high-ranking diplomats and well-connected individuals in Stockholm to produce reports not only on Swedish affairs but on the security situation of the Soviets, the Germans, and the United States, too. For example, he speaks of one of “(...) my agents here who has contacts in Russia (...)" to inform his ministry of an alleged meeting between US Secretary of State Cordell Hull and Soviet Ambassador Maxim Litvinov. ${ }^{78}$ On another occasion, Okamoto telegraphed back to Tokyo that he had talked with "an authority on Russia here who has connections with the Soviets (...)" to report about the situation of Soviet military preparations for the next German attacks. ${ }^{79}$ The minister was trying to find ways to extend the reach of his intelligence assessments through local informants.

Another source of Japanese spying was the military attaché, Onodera Makoto. Until 1940, Japan did not station military attachés in Stockholm, as the Scandinavian post used to be located in Helsinki, staffed by Officer Nishimura Toshio. But with the onset of the Soviet-Finnish Winter War, Helsinki became too dangerous and all Japanese diplomats were evacuated. Nishimura relocated to Stockholm and, in early 1941, was replaced by Onodera who had had some experience in the Baltic region through an earlier posting in Riga (1936-1938). He started working in Stockholm in February 1941.$^{80}$ Within months he had rebuilt connections to former friends and informants from his time in Latvia. His wife, Onodera Yuriko, chronicled in her memoirs the life of her husband and her family in Sweden. According to her, Onodera received important intelligence from 


\section{Fully engaged}

Hungarian, German, Estonian, and Polish informants. ${ }^{81}$ For instance, his Polish partners provided information about developments in Moscow and London. He forwarded reports based on his Polish sources to Tokyo under the heading "BU-Info." The records of United States counterintelligence reports, the so-called Magic Summaries, reveal that the US codebreakers were able to catch some of that information but not all. One of the summaries, written on August 24,1943 , states that

[t] here has come to hand a 'BU Intelligence' report (...) dated May $8(\ldots)$. Note: 'BU Intelligence' reports all seem to come from the Japanese military attaché in Stockholm and to cover information purporting to come from London and Moscow. The British believe that the information is supplied by agents. As yet there are not enough 'BU' reports available to permit dependable evaluation. ${ }^{82}$

Onodera's Polish connection was maintained throughout the war without his spies being uncovered. Although some of his reports were picked up by British and US intelligence services, not enough of them could be intercepted. Minister Okamoto, on the other hand, like many Japanese diplomats, left a visible trail of his activities. He did not believe that the Japanese cypher code had been broken and continued to send his reports via telegraph to Tokyo, which the Allies intercepted with ease. The Magic Summaries speak a clear language. Before December 1942, there were only little and sporadic news about Japanese activities in Stockholm, but once Okamoto commenced his activities Stockholm appears regularly in the reports.

Two insights can be deduced from these episodes. Firstly, it was the development of the war in Europe that increased Tokyo's interest in Stockholm. Otherwise, Minister Bagge would not have had to fight for nearly two years to receive a new minister plenipotentiary for Sweden. Secondly, Swedish authorities obviously had little objections to receiving such an extensive number of Japanese diplomats, since they could have blocked the arrival of them by withholding their accreditation. Hosting 15 Japanese diplomats meant more than adhering to etiquette, it signified consent to Japan's newly found use for Sweden. But then again, why would the UD oppose that development? It granted the same rights to all belligerents. In 1945, Germany and the USSR both had 21 accredited diplomats in Stockholm, the British were represented with 29 and the United States with 45. More importantly, the UD was not opposed to closer relations with Japan, as those could be used for Swedish interests in East Asia. As a neutral, Sweden only had to provide a level playing field.

\section{Trade}

\section{The quasi-nationalization of Swedish commerce}

Unsurprisingly, the events after Pearl Harbor did not help Swedish-Japanese trade relations. Only during the first two years of Japan's war against the Allies, 


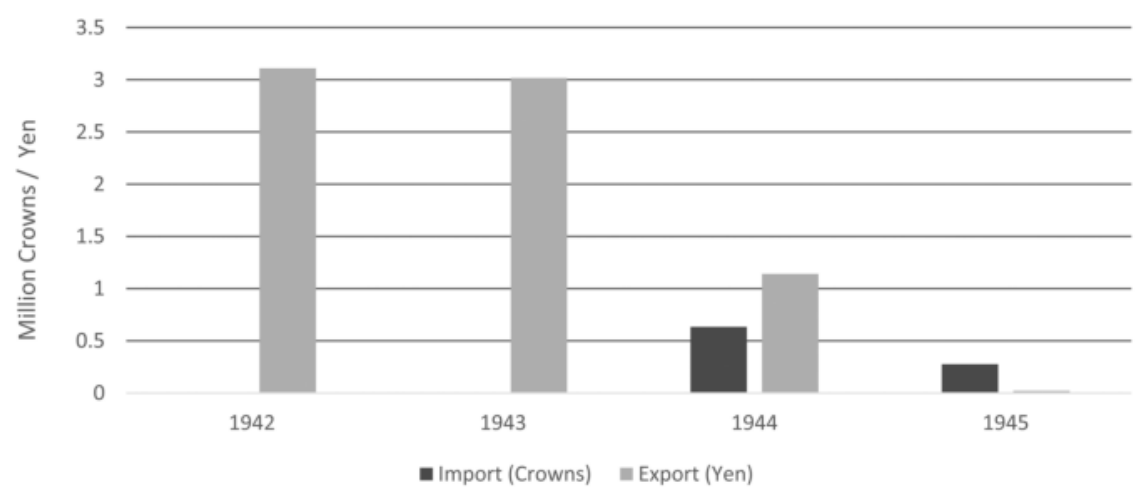

Figure 6.2 Swedish imports and exports to Japan 1942-1945. Source: For the Swedish data, see Centralbyrån, Statistisk årsbok 1946, 167. For the Japanese data, see Honma, Nippon-keizai, 40-41. Note: The graphic shows a mix of two datasets with imports in Swedish crowns and exports in Japanese yen. The official currency exchange rate between 1941 and 1945 was near parity. On international exchange rates, see Eidgenössisches Statistisches Amt, Statistisches Jabrbuch der Schweiz 1943 [Statistical Yearbook of Switzerland 1943] (Basel: E. Birkhäuser \& Cie, 1944), 210-211.

Sweden maintained limited levels of exports at a value of roughly 3 million. That was only a third of the export value for 1941 and only a fraction of the $¥ 49$ million that Japan used to import from Sweden in 1937. Figure 6.2 shows the low levels of trade that can be found in the official statistics. Import data for the years 1942 and 1943 are missing in the Japanese and the Swedish data. ${ }^{83}$ Even the existing numbers need to be interpreted with caution. It is possible that the Japanese figures are somewhat undervalued, especially for the first two years of the war. From Bagge's telegrams, it can be judged that Swedish exports were worth several million crowns. In March 1942 alone, there were still ball bearings worth SEK 2.3 million in the port of Yokohama and another SEK 2 million worth of SKF goods in transit in Siberia. ${ }^{84}$

The commodities that Sweden still wanted to import from Japan were rubber, soybean, tin, and tungsten. ${ }^{85}$ Japan on the other hand wanted to make use of Swedish raw materials like nickel and cadmium, and the country's ball bearings and piano wire, all of which had military use. Swedish wool and yarn were also still a welcome commodity ${ }^{86}$ Both sides agreed that negotiations should be held but under the cloak of secrecy. The Swedish Bureau of Foreign Trade, under Gunnar Hägglöf, was aware that trade with Japan would not only meet fierce resistance from the Allied side but would probably also be unpopular among the Swedish workers who made the goods ${ }^{87}$ Nevertheless, negotiations continued for several reasons. For one, Bagge was constantly afraid of Swedish merchandise being confiscated for the war without due payment to the owners. 


\section{Fully engaged}

Ever since summer 1941, he reported about the danger of expropriation or undervalued payments, especially of nickel shipments. ${ }^{88}$ One of them-69 tons of nickel and cadmium-had arrived at Yokohama in late November 1941, but was blocked in the port for months, which left Bagge to negotiate back and forth for the release at an advantageous price. ${ }^{89}$ These efforts were complicated by Japan's economic development that went into a steep inflation. Bagge reported that the price level had increased four-fold compared to $1937 .{ }^{90}$ Modern economic estimates of Japanese war inflation levels range around the same estimates, between a two- and six-fold increase compared to 1936 levels. ${ }^{91}$ The volatility of the general price level made the Swedish negotiations thornier and more difficult.

Without doubt the most significant change in trade relations occurred due to a radical transformation of Japan's mode of production. From early 1942 onward, the country's main industries reached a level of integration with the national government that made the two nearly indistinguishable. Markets were eliminated and all trade was refocused on the needs of the war economy. The largest national companies like Mitsubishi and Mitsui were ordered by the government to execute trade in compliance with its wishes. Bagge reported in February 1942 that

the Finance Ministry has given Mitsubishi an exclusive mission on behalf of the Japanese government to act as buyer of the goods. The legation is negotiating with the Foreign Ministry on the selling principles while a final contract and a delivery is made to Mitsubishi that will have all the details about the goods and is working in cooperation with the Planning Board and the military authorities who will have the right to decide. ${ }^{92}$

This nationalization of Japan's industry changed the way of trade with Sweden distinctly and put Bagge at the center of business interactions. As the official representative of the Swedish state, he had the strongest bargaining position. Trading companies like Ekman, Gadelius, and SKF did not matter anymore. Bagge could receive much higher price concessions when he intervened on their behalf. With a certain sense of pride, he reported in March that "regarding the nickel question (...) of last October, Gadelius could not even get half of the price I did." ${ }^{93}$ In the same telegram, Bagge describes clearly that the trading companies were in no position to take care of their core business anymore:

[T] he legation considers itself able to save considerable values otherwise threatened by war risks. The firms seem to have small qualifications in this respect and have not by themselves taken any initiatives in this direction which would have eliminated war risk responsibility. In the current situation, interference from the firms in the sales procedures would be inappropriate and harmful. However, the firms, in their own interest, will be contacted by the legation in order to keep the prices up. That is for instance of importance for band- and frame-saw steel. For this purpose, Gadelius has been consulted regarding the steel shipments. ${ }^{94}$ 
Indeed, over the next three and a half years the legation remained at the center of business interactions, negotiating prices and quantities of goods imported and exported. Some trading companies complained about this interference from the side of the legation but Bagge was convinced that under the new circumstances individual foreign firms needed state intervention on their behalf. He argued his case as follows.

It is desirable that stranded goods are sold as soon as possible, considering the risk of confiscation and damage. If this task was entrusted to the private firms, they would not be able to escape the sales and price controls exerted by government agencies and business organizations. The sales would be separated, and the shipments subdivided. Only the most sought-after parts would be sold with much reduced profit margins. The legation has been able to discuss the matter with the Foreign Office and the Ministry of Finance and the principles have been adjusted under a negotiation with them, skipping otherwise normal control procedures. The sales can now be organized following uniform procedures quicker and bigger in scale. (...) The criticism from Gadelius is not trustworthy and bears witness of an inability or unwillingness to understand the situation. ${ }^{95}$

Be that assessment correct or not, the record of the legation suggests that over the next years all trade issues exceeding a few thousand yen went through the hands of the legation. From wool and yarn to large shipments of ball bearings, nickel, and piano wire, the legation was involved. Entire telegram threats were labeled as pertaining to the so-called "nickel question" or the "rubber question," the former being a good that Bagge helped to import to Japan, whereas the latter was the major export item that the Swedish Trade Bureau wanted to receive from Japan. ${ }^{96}$

In connection to this role as Swedish trade organizer, the legation also functioned as a financial intermediary through its account at the Yokohama Specie Bank, which enabled the clearing system with the Riksbank in Stockholm. Any trade that was settled in Japanese yen but had to generate income in crowns needed to go through that clearing. This had the beneficial side effect that liquidity for other work areas of the legation was created. Bagge only had to debit the accounts that he kept for the trading companies on which they then earned interest. After some negotiations with the Gaimushō, the Japanese side agreed that the funds could be used in the entire yen-block. That enabled the use of funds for the well-being of the Ningpo and Miramar crews in Hong Kong and Saigon (see below); the payments of the consulates in Shanghai, Saigon, Hong Kong, and Dairen; as well as for the legation itself to fulfill its Protecting Power mandates. ${ }^{97}$ In summer 1942, for example, Bagge informed the UD that the Section $\mathrm{B}$ during the six months that it existed had had roughly $¥ 175,000$ in costs for which he borrowed SKF's money at 4.25 percent interest. ${ }^{98}$ This availability of yen denominated funds explains why the legation was never caught in a liquidity 
crunch. Money for its humanitarian activities was available due to its undertakings for Swedish companies.

From these records it can only be judged that the nationalization of industries in Japan led to a quasi-nationalization of Swedish trade under the legation. Although Swedish companies were not nationalized as such, their Japanese subsidiaries became completely dependent on the legation and Bagge's powers as a plenipotentiary to negotiate directly with Japanese ministries. The companies were reduced to executing offices. The integration of trade and diplomacy is also evident from the many former businessmen, like Ericson, who became legation staff-in his case even a diplomat.

\section{Worsening relations on all fronts}

Overall, the small concessions that Bagge could still get for Swedish trade could not forestall the worsening situation for its commerce in Asia. On December 30, 1941, Japanese forces had seized the Swedish steamer S.S. Miramar at the port in Saigon. ${ }^{99}$ Bagge learned of this event only ten days later when the consulate in Vietnam informed him about the capture of the ship and its Swedish crew, who were taken to an unknown location. ${ }^{100}$ The reason given by Japanese officials was that the neutral ship was suspected of carrying contraband and would therefore be handed over to a prize-court. Bagge protested this treatment and the possible appropriation immediately. He took the case to Foreign Minister Tōgō, where he protests sharply: "I have insisted toward the Japanese authorities (...) that the benevolence and good-will of Sweden as a neutral, friendly country must not be taken for granted. (...) the gain that Japan can achieve by confiscating Swedish property can hardly outweigh the damage caused by the loss of trust."101 Unfortunately, nothing was gained by the strong words. Over the next two years, the Miramar case became a major strain on Swedish-Japanese relations. The Japanese side simply refused to release the ship. The Swedes, therefore, had to settle for a compromise according to which the Miramar would be leased to the Japanese Navy at an advantageous rate that was to be paid in yen. ${ }^{102}$ The crew went free and could be repatriated, but the ship had effectively been surrendered to Japan. ${ }^{103}$ Minister Bagge stressed in one of his many reports regarding the affair that "this is not a question of free negotiations since the Japanese dictate the terms through prize-courts and confiscations." 104 The Miramar was thereby involuntarily leased to the Japanese state and that was not the only such case. At least one other ship, the Ningpo $M V$, shared the same fate. After suffering heavy collateral damage during the Battle of Hong Kong, where it was anchored at the time when the war broke out, the ship was repossessed by Japan to serve as a merchant steamer. ${ }^{105}$ It was sunk sailing under Japanese flag on June 29,1944 , torpedoed by a US submarine. ${ }^{106}$

A similar high-profile case was the treatment of Swedish interests on Japaneseoccupied territories in China. Although the official foreign policy of the Empire was not to interfere with neutral interests, the reality looked different-especially in the case of the American Far Eastern Match Co., a subsidiary of Svenska Tändsticks $A B$ (STAB), a producer of matches, lighters, and tobacco products. ${ }^{107}$ 
Because of the unfortunate naming, the Shanghai-based subsidiary was seized by the Japanese army at the beginning of the war. Bagge tried to correct the misunderstanding, stressing that the company was fully owned and controlled by Swedish capital but his repeated demarches at the Gaimushō had little effect. ${ }^{108}$ The company was not returned and could not operate anymore. The issue was so important to the Swedes that the UD got involved as well, negotiating the case still a year later with the newly appointed Minister Okamoto. ${ }^{109}$ The treatment of Swedish interests regarding STAB and the Miramar were the two most contentious bilateral issues plaguing Swedish-Japanese relations until well into 1943, partially shattering Minister Bagge's initial hopes that Sweden's Good Offices for Japan would translate into benevolent treatment.

By 1944, the situation of the European war had deteriorated for the Axis Powers to the point that the only possible transport route for cargo from Sweden to Japan was by submarine from Germany. Steel balls, ball bearings, and piano wire were brought to Japan underwater. ${ }^{110}$ Onodera's office organized the purchases in Stockholm but a Swedish company carried out the actual transport. ${ }^{111}$ The quantities were, of course, much smaller than what they used to be when proper shipments or rail transports via Siberia were still possible. On the side of the Swedish legation, all business correspondence related to rubber exports for Sweden came to an end in late 1943 and the last telegram pertaining to the sales of nickel to Japan is dated February 1, 1944. During the last 18 months of the war, trade between the two nations came to a near standstill.

Diplomatic relations between Sweden and Japan also started suffering in 1944. A wedge was driven between the Swedish mission and its host by the mandatory evacuation of the legation to Karuizawa, a town in the mountains of Nagano prefecture. Bagge and his neutral colleagues from Spain, Switzerland, Portugal, and Turkey jointly protested with verbal notes against the forceful removal of their legations from Tokyo. But the Gaimushō argued that the evacuation was necessary to protect the diplomats from the danger of US air raids and that there was no practical downside to the legations because there would be a Gaimushō branch office in Karuizawa to allow for continuous communication with the Japanese Government. Bagge and the other neutral ministers did not believe this line of argument. To them, the measures were nothing but an attempt at constraining their access to information about the development of the war. Tokyo was the center of political activities and an isolation from it impeded the Protecting Powers' ability to carry out their mandates. Especially the strict order not to travel to Tokyo without permission and police escort came as a blatant infringement on the freedom of movement guaranteed to diplomats under international law. Most suspiciously, the representatives of Axis Powers were not under that restriction, which made it all too clear that the primary concern of the Gaimushō was not to keep the diplomats safe but to cut off the flow of information from Tokyo to neutral governments - who might forward them to the Allied Powers. ${ }^{12}$ The written complaints did not help, the policy remained in force, and the diplomats were cut off from Tokyo. 


\section{Fully engaged}

In all fairness, it must be said that the evacuation to Karuizawa also did keep the legation safe, as the Gaimushō claimed. Nobody from the legation staff came to harm during the extensive bombings of Tokyo, in 1945. Still, the lack of access to the capital was an acute problem because the representation of foreign interest and the caretaking of Swedish citizens had become by far the most important tasks for the legation. Living conditions worsened on the Japanese mainland and its shrinking Empire overseas. In February 1944, Bagge had already reported of another joint neutral demarche, together with the Swiss and the Spanish legation, to request the evacuation of their citizens from Japanese-occupied territories in the Pacific. Especially the Swiss had been vocal for months that they wanted their citizens in occupied territories evacuated. The Japanese side had been ignoring these requests repeatedly. Joint diplomatic action was, therefore, aimed at increasing the pressure on the Gaimushō to receive at least an amelioration of the living conditions of the concerned neutral nationals. But again, the initiative failed. Neutral objections to their treatment inside or outside of Japan had rarely an impact anymore. At the same time, reports from Hong Kong and the Philippines of mistreatment of neutral nationals kept pouring in, especially in the latter half of 1944 and early 1945. The worst atrocities were committed in Manila, where more than a hundred Spanish and 20 Swiss citizens were executed by Japanese soldiers during the final battle for the city. The Swedes were luckier. Not a single casualty was reported. All 17 Swedish families who resided in Manila survived the slaughter. Only one Swede, Adolf Greiffe, was wounded by a shot from a Japanese officer but he and his family were alive. ${ }^{113}$

The incident in Manila was the reason why the Spanish finally relinquished their representations of Japanese interests in the Americas. For Sweden, no such question arose. In one of his last telegrams before departing back to Sweden (in April 1945), Bagge instructed his ministry to prepare for the Japanese request to take over the country's interests in the United States, which were previously protected by Spain. He emphasized that if the Swedish Government decided to accept the mandate, it should not do so without using the request as a bargaining chip to receive important concessions for the Swedish mandates as Protecting Power in Japan. He wanted more food rations for the POWs, to have imprisoned Norwegians and Swedes freed, and arbitrary arrests stopped. ${ }^{114}$ In the end, Japan convinced the Swiss to represent Japan's interests in the Americas and Bagge could not make his demands heard. Nevertheless, the episode shows that the Swedish diplomats, much like their Swiss colleagues, tried to use every possible way to receive concessions from the Gaimushō to improve the way they and their protectees were treated. ${ }^{115}$

Despite all the problems, one of Sweden's most important wartime favors to Japan was yet to come. Toward the second half of 1944, it became increasingly clear that Japan would not end up on the victorious side of this total war. With the US Navy approaching, the imperial forces in retreat, and American bombers bringing havoc to mainland cities, many Japanese inside and outside of political circles became aware of the urgency to end the war. But how to do that? A negotiated peace that would spare Japanese militarism from dismantlement was out of the question for the United States who made it clear that nothing short 
of unconditional surrender was acceptable to Washington. But in Tokyo, even to peace-minded cabinet members like Foreign Minister Shigemitsu, only an end that was "consonant to the honor of Japan" was an acceptable solution. ${ }^{116}$ The central issue was to preserve Japan's polity (kokutai), with which the survival of the institution of the Emperor was inextricably linked. The possibilities of the Emperor's political (and physical) survival had to be sounded out. ${ }^{117}$ One of the best chances for that would occur through the Good Office of Minister Bagge.

\section{Summary}

Pearl Harbor was a watershed moment for Swedish-Japanese relations. Diplomatically, Sweden became Japan's second largest Protecting Power and one of the three neutrals tasked with organizing the exchange of enemy nationals among the belligerents. Especially its role as Japan's Protecting Power in Hawaii and as provider of exchange ships made it a crucial neutral partner to Tokyo. On the other hand, Sweden collaborated in several areas with Switzerland to protect Allied POWs, diplomats, and civilians. It also became an enabler for private humanitarian relief efforts by lending a helping hand to the Neutral Committee of the YMCA, consisting of Swedish and Swiss diplomats, which acted as the Japan-based branch of the international YMCA. Through the committee, the Swedes could channel YMCA goods and funds to interned enemy nationals in the Empire. While Switzerland was the diplomatic partner of the ICRC, Sweden became the partner of the YMCA.

For Swedish business, everything changed with Japan's new mode of production for the war economy. Trade and diplomacy became so interconnected that they were barely distinguishable. Widar Bagge suddenly was not only Sweden's highest diplomatic representative in Japan, but also became the chief representative of Swedish commerce. Only he had the necessary authority to negotiate prices with the Ministry of Finance. Japan's nationalization drove, to a large extent, a quasi-nationalization of Swedish trade in the country under its diplomatic outpost. This went so far that Swedish companies complained about the interference of the legation in their business. Minister Bagge defended the measures, arguing that under the new rules of the game, only the Swedish state-as represented by him-had an adequate standing for negotiations with Japan. Indeed, he was able to get higher concessions than the company directors.

Paradoxically, the new role Sweden came to play occurred in tandem with Japan's declining interest in bilateral relations with the Scandinavians. For nearly two years (January 1941-November 1942), Japan did not have a minister plenipotentiary stationed in Stockholm, operating its legation on minimum capacity only. Sweden strongly disliked the situation since it meant even fewer possibilities to make its interests and grievances heard in Tokyo. The official reason the Gaimushō gave was a lack of skilled personnel, but the truth was probably more mundane-the geopolitical situation of these years had isolated Sweden in the eyes of Japan, making diplomatic efforts there unnecessary. That perception changed radically toward the final years of the war. Once the Gaimushō and 


\section{Fully engaged}

Japan's armed forces realized the value of Stockholm as an outpost for intelligence gathering, Japan sent not only a new minister but a dozen delegates to gather information on Allied activities.

Sweden's new role as a provider for diplomatic and humanitarian services increased the workload of the UD considerably. To cope with the situation, it founded a division dedicated only to foreign interests, the Section B. In Japan, Bagge made a former Swedish company director the head of his local chapter of that section. In general, Bagge had to hire many more Swedish and Japanese employees to cope with the increased workload. His mission grew from a handful of people to over 20. Besides the apparent necessity to assist individuals in danger, Bagge recommended to his government not to turn down request for Sweden's Good Offices because he hoped that these favors would grant Sweden an advantageous position for its own interests, especially inside Japan. These expectations, however, did not come true. With every year of the war, it became more difficult for Bagge to uphold commercial interests and to protect even Swedish citizens in the Japanese Empire.

\section{Notes}

1 Nomura to Roosevelt, Transcript of speech (GMS, M.2.1.013-6).

2 Draft text of Bilateral Agreement, June 21, 1941. (JACAR, B02030738100).

3 Nish, Japanese Foreign Policy 1869-1942, 244.

4 Nish, Japanese Foreign Policy 1869-1942, 244-245.

5 Grew, Ten Years in Japan, 350-355.

6 Bagge to UD, Telegram, September 4, 1941 (BA, 230033.2, E2, I).

7 Bagge to UD, Telegram, December 8, 1941 (BA, 230033.2, E2, I).

8 Norrskensflamman, "Alla världsdelar och världshav i krig" [All continents and oceans at war], December 8-15, 1941.

9 Social-Demokraten, "Kampen om Stilla havet" [The struggle over the Pacific], December 9, 1941.

10 Svenska Dagbladet, "Världsbranden vidgas" [The world conflagration expanding], December 8, 1941, and "Rovriddarens väg" [The path of the Robber Baron], December 9, 1941.

11 Göteborgs Handels- och Sjöfartstidning, December 8, 1941. "Tigersprånget i öster" [The tiger leap in the east].

12 Svenska Dagbladet, "Julmånadens krigsbudskap" [The war message of the Christmas month], December 12, 1941 .

13 For the deliberations of the Foreign Policy Committee, see Lars Frykholm and Margareta Brundin, eds., Samråd $i$ krigstid: Utrikesutskottets memorialprotokoll 1940-1945 [Wartime consultation: The Foreign Affairs Committee's memorial protocol 1940-1945] (Stockholm: Sveriges Riksdag, 2007).

14 Parliamentary Records 1942 FK, No. 3 and AK, No. 3.

15 Parliamentary Records 1943 FK, No. 30, 11.

16 Agrell, Fred och fruktan, 64, 66; Wilhelm M. Carlgren, Svensk underrättelsetjünst 1939-1945 [Swedish intelligence service, 1939-1945] (Stockholm: Liber, 1985), 10, 100-102; Wilhelm Agrell, Stockholm som spioncentral: spairen efter tre hemliga städer [Stockholm as a spy center: Traces of three secret cities] (Lund: Historiska Media, 2020), 59-62, 115.

17 Agrell, Fred och fruktan, 63; Agrell, Stockholm som spioncentral, 59-62, 68. Allmänna säkerhetstjänstens arkiv [Archives of the Swedish Public Security Service], F 2 BB:2 and F 2 BB:3. 
18 Agrell, Fred och fruktan, 75-76, 84; Agrell, Stockholm som spioncentral, 59-62, 115 .

19 Hadenius, Modern svensk politisk historia, 78-79.

20 Agrell, Fred och fruktan, 89-92. Svenska Dagbladet, "Svenskarnas tårar kommer aldrig att torka" [The tears of the Swedes will never run dry], January 25, 2016.

21 Newsom, Diplomacy under a Foreign Flag.

22 Nils R. Larsson, Sverige som skyddsmakt: historik och praxis [Sweden as a Protecting Power: History and practice] (Stockholm: Norstedt, 1988), 10-11.

23 Larsson, Sverige som skyddsmakt, 12-13.

24 Bagge to UD, Telegram, April 25, 1942 (BA, 230033.2, E2, I).

25 Kallin to Bagge, Letters, July 2 and 3, 1942 (BA, 230033.2, E4, III).

26 Protecting Power mandates were dynamic, starting and ending at different times. The number of 136 mandates is derived from various lists that the UD kept for the World War II period (UDA, 2210.03.1, P19, A).

27 Forty-seven Protecting Power mandates involved Japan or Siam or the United States and Mexico which entered the war as a direct result of Pearl Harbor. See lists in UDA, 2210.03.1, P19, A.

28 Ibid.

29 Bagge to UD, Telegrams, December 8 and 10, 1941 (BA, 230033.2, E2, I).

30 Eleanor C. Nordyke and Scott Y. Matsumoto, "Japanese in Hawaii: A Historical and Demographic Perspective," Hawaiian Journal of History 11 (1977), 165166.

31 M. Slackman, Target: Pearl Harbor (Honolulu: University of Hawaii Press, 1991).

32 Kaori Akiyama, Hawai nikkeijin no kyōsei shüyōshi: Taiheiyō sensō to yokuryüsho no bensen [The history of Japanese internment in Hawai' $\mathrm{i}$ : Changes in the camps and camp life during the Pacific War] (Tokyo: Sairyūsha, 2020).

33 Paul Scott Corbett, Quiet Passages: The Exchange of Civilians between the United States and Japan during the Second World War (Kent: Kent State University Press, 1987), 46.

34 Bagge to UD, Telegram, December 30, 1941 (BA, 230033.2, E2, I).

35 Bagge to UD, Telegram, January 5, 1942 (BA, 230033.2, E2, I).

36 Bagge to UD, Telegrams, December 22 and 30, 1941 (BA, 230033.2, E2, I). On December 20, the declaration of war from Belgium on Japan followed and that of Mexico was proclaimed four months later. On the Belgian declaration of war, see also: Raoul Delcorde, Belgian Diplomats, ed. Pierre Mardaga (Wavre: Mardaga, 2010), 65.

37 Craigie, Behind the Japanese Mask, 152.

38 Bagge to UD, Telegram, December 22, 1941 (BA, 230033.2, E2, I).

39 No records are detailing how and why Kallin was appointed, but there exists a short record on him. See Kallin to Bagge, Letter, December 31, 1942 (BA, 230033.2, E4, III).

40 From the records of the consulate it is not clear why there was another change from Heseltine to Kallin because there is a considerable gap in the documentation. Between October 31, 1940, and January 20, 1941, no files are available in the folder of consular correspondence.

41 Kallin to Kondo, Letter, May 14, 1942 (BA, 230033.2, E4, III).

42 Bagge to UD, Telegram, June 15, 1942 (BA, 230033.2, E2, I). On the employees of the B-Section, see also the financial statements of the legation, March 3, 1943 (UDA, 2212.02, F 1 Grupp 1, Xj).

43 Bagge to UD, Telegram, February 23, 1942 (BA, 230033.2, E2, I).

44 Kallin to Bagge, Letter, July 29, 1942 (BA, 230033.2, E4, III).

45 Kallin to Bagge, Letter, July 31, 1942 (BA, 230033.2, E4, III). 
46 Ericson to Yokohama Consulate, Letter, July 3, 1945 (BA, 230033.2, E4, IV).

47 There are no lists of the mission personnel, but they are mentioned sometimes in reports from the legation. In addition to the already mentioned people, the following employees were also on the legation's payroll but in less important positions: John Andersson (mechanical engineer), Arne Svenson (captain), Oscar Petterson, and E. B. Gawell. See Memorandum, November 25, 1943 (BA, 230033.2, F2c, I).

48 Bagge to UD, Telegram, May 7, June 11 and 21, 1943 (BA, 230033.2, E2, I).

49 Gaimushō to Swedish Legation, Note Verbale, March 9, 1942 (BA, 230033.2, F2b, I). Also available in Lottaz, "Neutral States and Wartime Japan," 467-468.

50 These provisions were only valid for Japan proper. The Gaimushō explicitly ruled out the authority of Protecting Powers on occupied territories. See: Gaimushō to Swedish Legation, Note Verbale, October 1, 1942 (BA, 230033.2, F2b, I).

51 Bagge to UD, Telegram, February 11, 1943 (BA, 230033.2, E2, II).

52 The most reliable source of the visits is a list of camp visits for the time between February 1942 and June 1943. The list mentions that some visits to Kobe were not recorded. The average of three to four visits per month is an estimate. See "Visit to Civilian Internment Camps," List, July 5, 1943 (BA, 230033.2, F2b, I).

53 Gaimushō to Swedish Legation, Note Verbale, July 7, 1943 (BA, 230033.2, $\mathrm{F} 2 \mathrm{~b}, \mathrm{I})$.

54 Kjellin to Bagge, Letter, December 25, 1941 (BA, 230033.2, F2b, I).

55 Bagge to UD, Telegram, January 19, 1942 (BA, 230033.2, E2, I).

56 E.g.: Heseltine to Bagge, Letter, February 27, 1942 (BA, 230033.2, E4, III).

57 Kallin to Bagge, Letter, March 27, 1942 (BA, 230033.2, E4, III).

58 For example, the case of the S.S. Herleik, sailing under Panama flag and seized in the port of Hong Kong. Kishi Law \& Patent Office to Troedsson, Documents, June 27, 1942 (BA, 230033.2, F2b, I).

59 Bagge to UD, Telegrams, December 8 and 10, 1941 (BA, 230033.2, E2, I).

60 The request concerned the property of the Yokohama Amateur Rowing Club which was a private club, jointly owned by several legations and embassies. The club was designated as "enemy property" and seized by the Japanese police, in early 1942. Since diplomats of Axis Powers as well as many neutrals were among the owners of the club, Kallin was involved in a joint intervention toward the Gaimushō. Kallin to Bagge, Letter, July 21, 1942 (BA, 230033.2, E4, III).

61 Political Department to Dubois, Telegram, September 28, 1945 (Swiss Federal Archive, E2001D\#1000/1553\#1980*).

$62 \mathrm{He}$ was sent there to officially close the British consulate but died under mysterious circumstances on the voyage back home. He was most likely murdered on board of the ship from Formosa to Kobe. See Lottaz, "Neutral States and Wartime Japan," 412-413.

63 Ericson "Report on Visit to the Formosa War Prisoners' Camps," Report, September 21-October 2, 1945 (BA, 230033.2, F2e, III).

64 The Soviet Union was mentioned only as part of Bagge's political observations on the situation of the war and Japanese-Soviet mutual distrust (BA, 230033.2, E2, I).

65 The YMCA became an object of popular culture in 1978 when the US-American disco group Village People created the iconic pop song Y.M.C.A.

66 Jon Thares Davidann, Cultural Diplomacy in U.S.-Japanese Relations, 19191941 (New York: Palgrave Macmillan, 2007); R. J. Jensen, J. T. Davidann, and Y. Sugita, Trans-Pacific Relations: America, Europe, and Asia in the Twentieth Century (Westport: Praeger, 2003).

67 "Confidential Memorandum concerning the international YMCA activities in Japan," November 25, 1943 (BA, 230033.2, F2c, I). 
68 Ibid., 6.

69 Ibid., 2.

70 Ibid.

71 Ibid., 3.

72 Ibid., 6.

73 "International YMCA-7th Meeting of the Working Committee," Meeting Minutes, June 4, 1943 (BA, 230033.2, F2c, I).

74 Bagge to UD, Telegram, November 4, 1942 (BA, 230033.2, E2, I).

75 Onodera, An den Gestaden der Ostsee, 156.

76 See dossier on Okamoto's appointment (JACAR, B14090870300).

77 LHMA, MAGIC Summary No. 332, February 21, 1943.

78 Ibid., No. 382, April 12, 1943.

79 Ibid., No. 384, April 14, 1943.

80 Also the military attaché in Riga, Hiroshi Onouchi, was evacuated to Stockholm. Onodera, An den Gestaden der Ostsee, 57.

81 Onodera, An den Gestaden der Ostsee, 110.

82 LHMA, MAGIC Summary No. 516, August 24, 1943.

83 Swedish statistics between 1940 and 1945 only hold data for imports in 1944 and 1945. The Japanese data is complete on imports (i.e., Swedish exports) until 1945 but only records exports (i.e., Swedish imports) until 1941.

84 Bagge to UD, Telegrams, March 24, 27, and 31, 1942 (BA, 230033.2, E2, I).

85 LHMA, MAGIC Summary No. 272, December 23, 1942, 6.

86 Bagge to UD, Telegrams, April 25 and June 10, 1942 (BA, 230033.2, E2, I).

87 LHMA, MAGIC Summary No. 272, December 23, 1942, 7.

88 Bagge to UD, Telegrams, August 30 and September 29, 1941 (BA, 230033.2, E2, I).

89 Bagge to UD, Telegrams, December 1 and 12, 1941, and January 13, 1942 (BA, 230033.2, E2, I).

90 Bagge to UD, Telegram, June 29, 1942 (BA, 230033.2, E2, I).

91 Mark Harrison, The Economics of World War II: Six Great Powers in International Comparison (Cambridge: Cambridge University Press, 2000), 261.

92 Bagge to UD, Telegram, February 17, 1942 (BA, 230033.2, E2, I).

93 Bagge to UD, Telegram, March 24, 1942 (BA, 230033.2, E2, I).

94 Bagge to UD, Telegram, February 17, 1942 (BA, 230033.2, E2, I).

95 Bagge to UD, Telegram, March 14, 1942 (BA, 230033.2, E2, I).

96 The indices of the telegraphic correspondence of the legation were recorded with content tags for certain issues. Evacuation-related telegrams were labeled "Evak.," foreign interests received an "S," YMCA issues were called "KFUM", and among the same tags we also find "Gummi" for the rubber business and "Ni." for nickel issues.

97 Bagge to UD, Telegram, February 2, 1942 (BA, 230033.2, E2, I).

98 Bagge to UD, Telegram, July 2, 1942 (BA, 230033.2, E2, I).

99 LHMA, MAGIC Summary No. 384, April 14, 1943.

100 Bagge to UD, Telegram, January 10, 1942 (BA, 230033.2, E2, I).

101 Bagge to UD, Telegram, March 3, 1942 (BA, 230033.2, E2, I).

102 Bagge to UD, Telegram, July 7, 1942, (BA, 230033.2, E2, I).

103 Bagge to UD, Telegrams, January 14 and 15, 1943, (BA, 230033.2, E2, II).

104 Bagge to UD, October 24, 1942 (BA, 230033.2, E2, I).

105 Bagge to UD, Telegram, February 19, 1942 (BA, 230033.2, E2, II).

106 The Wrecksite Database. "Ningpo MV (1938-1943)," accessible at www.wrecksite.eu/wreck.aspx? 178046.

107 Swedish legation to Gaimushō, Memorandum (JACAR, B02032937000).

108 Bagge to Gaimushō, Letter, July 8, 1942 (JACAR, B02032937100). 


\section{Fully engaged}

109 LHMA, MAGIC Summary No. 378, April 8, 1943.

110 LHMA, MAGIC Summary No. 988, December 8, 1944.

111 Onodera, An den Gestaden der Ostsee, 177.

112 Bagge to UD, Telegram, July 17, 1944 (BA, 230033.2, E2, II).

113 UD to Legation, Telegram, March 17, 1945 (BA, 230033.2 E1, II).

114 Bagge to UD, Telegram, April 11, 1945 (BA, 230033.2, E2, III).

115 On Switzerland, see Lottaz, "Neutral States and Wartime Japan," 331-440.

116 Shigemitsu, Japan and Her Destiny, 339.

117 Krebs, "Aussichtslose Sondierung." 


\title{
$7 \quad$ In the end \\ Widar Bagge, Japan, and the end of World War II
}

\author{
Bert Edström ${ }^{1}$
}

In the final phase of the war, Sweden became involved in a maneuver aimed at attaining peace for Japan on terms acceptable to its military and political leadership. In the autumn of 1944, it was obvious to some influential Japanese that defeat in the war was inevitable, and various channels were used to sound out the possibility of reaching a peace agreement. One of these channels involved the Swedish minister to Tokyo Widar Bagge in what is now known as the Bagge kosaku, "the Bagge maneuver," often also called "the Bagge peace feeler." The endeavor in which he was involved differed in one important respect from all other peace efforts in that two (successive) Japanese foreign ministers supported it. Although none of the initiatives came to fruition, it is still worth pausing to consider this moment of a failed peacemaking effort, as it exemplifies both the possibilities and limitations of neutral diplomacy. Bagge's deed has entered the annals of Japan's diplomatic history but is mentioned only in passing in the standard work on Swedish foreign policy during World War II written by Wilhelm Carlgren, the head of the archive of the Swedish Foreign Ministry 1965-1987. Bagge appears only briefly in a footnote in this monumental work of almost 600 pages. $^{2}$

Carlgren's history was published in 1973. The following year he was contacted by the diplomat Erik von Sydow, who, as we have seen, had worked under Bagge at the Swedish legation in Tokyo during the war. Von Sydow had been contacted by the British historian Louis Allen, who wanted him to comment on a prospective book chapter about "the Bagge peace feeler." Von Sydow forwarded the query to Carlgren and asked for his comments. In his response, Carlgren

1 This is a revised and updated version of a paper presented at the Fourth Nordic Symposium on Japanese and Korean Studies, University of Aarhus, Aarhus, Denmark, September 5-8, 1995, and subsequently issued as Center for Pacific Asia Studies at Stockholm University, Working Paper 41 (October 1995), $22 \mathrm{pp}$. The idea of writing the original paper was suggested by Professor Ōhata Tokushirō, Waseda University, Tokyo, in a discussion with the author about the role Widar Bagge briefly played in the final stage of World War II. The original paper benefited from discussions with Dr Berndt Fredriksson, Head, The archive of the Foreign Ministry, and Ambassadors Gunnar Jarring, Erik von Sydow, Sven Dahlman, and Mrs Onodera Yuriko.

2 Carlgren, Svensk utrikespolitik 1939-1945, 582.

DOI:10.4324/9781003182061-7 
suggested that the background to Bagge's involvement in the move (instigated by peace-inclined Japanese) might have originated in Sweden's achievements as a peace broker in the Continuation War (1941-1944) between Finland and the Soviet Union. They might have given the Japanese "the impression that [Foreign Minister] Günther and his collaborators possessed the discretion and dexterity needed in this kind of delicate matters."3 Maybe von Sydow's letter made Carlgren look into Bagge's deed a bit more thoroughly than he had found necessary when he wrote his 1973 history. In 1985 he included a description of Bagge's effort in a study of Swedish mediation during World War II. ${ }^{4}$ In any event, the following is the most detailed historical account (as of 2020) of "the Bagge maneuver" based on published and unpublished sources from Sweden and Japan.

\section{The Bagge peace feeler}

Widar Bagge was a senior diplomat but never belonged to the upper echelons of the Swedish foreign service. ${ }^{5}$ According to one of his colleagues in the Swedish diplomatic corps, he was known as a demanding head of mission who had a pedantic disposition and was very conscious of diplomatic etiquette and his own dignity. ${ }^{6}$ Another colleague who worked under Bagge at the Swedish legation in Tokyo 1940-1945 describes him as annoyed that he had only one embassy secretary at his disposal while the Swiss minister had one counsellor and two embassy secretaries. 7 This colleague described Bagge as a "difficult person,"

3 Wilhelm Carlgren to Erik von Sydow, Letter, October 13, 1974. Copy of letter provided by Ambassador von Sydow.

4 See Wilhelm Carlgren, "Die Mediationstätigkeit in der Außenpolitik Schwedens während des Zweiten Weltkrieges," in Schwedische und schweizerische Neutralität im Zweiten Weltkrieg, eds. Rudolf L. Bindschedler et al. (Basel, Frankfurt am Main: Helbing und Lichtenhahn, 1985), $109 f$.

5 For bibliographic information, see chapter 4. See also Pl Widar Bagge, vol. 2, Utrikesdepartementets arkiv 1920 års dossiersystem, Riksarkivet [The archive of the Foreign Ministry, Filing system of 1920, Swedish National Archives] (henceforth: UD).

6 Gunnar Jarring, Memoarer 1939-1952 [Memoirs, 1939-1952] (Stockholm: Bonnier, 1981), $144 \mathrm{f}$.

7 Personal communication from Erik von Sydow, January 29, 1994. According to Sweden's official gazette, the staff at the Tokyo legation in 1945 were Envoy Widar Bagge, First Legation Secretary Erik von Sydow, Second Legation Secretary Olof Ripa, and First Secretary Johan Hjortzberg-Nordlund. See Sveriges statskalender för året 1945 [Sweden's official gazette 1945] (Stockholm och Uppsala, 1945), 266. However, the staff was larger. After his return to Sweden in May 1945, Bagge stated in an interview that four officials and nine clerks worked at the legation. See "Svenskarna i Tokyo välbehållna" [The Swedes in Tokyo well], Dagens Nybeter, May 27, 1945.

8 Personal communication from Erik von Sydow, July 11, 1993. 
while a close relative characterizes him as "a loner." $\mathrm{He}$ certainly was a bit of a busybody. ${ }^{10}$

Bagge took up his post as Swedish minister to Japan on January 1, 1937, and was to remain in the country until mid-April 1945, except for short trips to other countries. When he left Japan for Sweden, he was the dean of the diplomatic corps in Tokyo. In standard reference works on Japanese foreign policy, he is described as a Japanophile. ${ }^{11}$ According to one of Japan's wartime foreign ministers, Shigemitsu Mamoru, who knew the Swedish diplomat, "Bagge had long resided in Tokyo, knew Japan well and had a high reputation for sincerity." 12 His good reputation in Japan seems to have been the reason why he was approached by peace-inclined Japanese and asked to assist in the attempts to bring the war to an end. Another consideration was that he was the representative of neutral Sweden, one of the few countries who could function as a go-between between Japan and its enemies.

The peace feeler was initiated in mid-September 1944 when Suzuki Bunshirō, an influential journalist and managing director of the Asabi Shimbun, one of Japan's largest dailies, contacted Bagge. They were old acquaintances. Mushakōji Kintomo, a former Japanese minister to Sweden, had introduced Bagge to Suzuki in 1937. ${ }^{13}$ According to Bagge's affidavit at the International Military Tribunal for the Far East (IMTFE), "Mr. Suzuki told me that Prince Konoye and a group of men around him were responsible for this plan which they wanted me to forward to the Swedish Government with the request that through Swedish channels a feeler should be made in London." 14 Bagge reported his conversation with Suzuki and the Japanese request in a telegram to the Foreign Ministry in Stockholm:

Telegram in Cl. I code from the Royal Legation in Tokyo, $19 / 91944$, at $12.0 \mathrm{~s}$

Arrived $19 / 9$ at 1350

Primo. I learn from a reliable source that influential civilian circles are discussing the peace problem with increasing concern. They expect a speedy German collapse and do not believe that Japan can resist. It is therefore

9 Personal communication from Lillebil Bagge, January 31, 1994.

10 Personal communication from Gunnar Jarring, September 5, 1994.

11 See Nihon gaikō hyakunen shōshi [A short history of the past century of Japanese diplomacy], ed. Gaimushō, rev. ed. (Tokyo: Yamada shoin, 1958), 230; and Nihon gaiköshi jiten [The encyclopedia of Japanese diplomatic history], ed. Gaimushō gaikō shiryōkan Nihon gaikōshi jiten hensan iinkai, 2nd ed. (Tokyo: Yamakawa shuppansha, 1992), 396.

12 Mamoru Shigemitsu, Japan and Her Destiny: My Struggle for Peace (London: Hutchinson, 1958), 339.

13 Suzuki Bunshirō, "Wahei kōsaku misui no ki" [Account of an attempted peace move], in Shüsen shiroku [Historical record of the termination of the war], ed. Gaimushō, vol. 2 (Tokyo: Hokuyōsha, 1977), 111.

14 Widar Bagge affidavit, in International Military Tribunal for the Far East (IMFTE), Record of Proceedings, 1946-1948 (Washington, DC: Library of Congress, microfilm, 1974), 34,560. 
considered necessary to attain peace as soon as possible before the countryside and towns are destroyed. They count on certain British war fatigue and generally consider

Secundo. a peaceful settlement with England would be easier than with the United States. To this end, they are prepared to return all areas taken from Great Britain during the war and recognize all former British interests and investments in East Asia. They are said to realize that other areas occupied during the war would have to be returned and

Tertio. that even the sacrifice of Manchukuo may be necessary. They want this explored in London and believe that this could be done through Swedish mediation on condition no British publicity. If understanding was found in London, they are prepared for preliminary discussions via Sweden.

Quarto. Behind my informer is primarily one of the best-known statesmen of the country and the above is without any doubt to apprehend as a serious feeler. If you deem it appropriate you may inform the English minister of the section secundo. Other sections only for your confidential information. Request that you communicate to me your opinion prima vista.

Bagge $^{15}$

On the copy of the telegram kept in the Swedish National Archives, two brief notes have been scribbled: "the Yellow cupboard" and "Mallet told by Günther 19/9." The Yellow cupboard in the office of the head of the political section of the Foreign Ministry was used for documents that were so sensitive that they had to be kept so secret that their existence was not even admitted. ${ }^{16}$ Günther was Christian Günther, the Swedish foreign minister, who contacted the British minister to Stockholm, Sir Victor Mallet, and personally informed him of Bagge's message. Ignoring Bagge's suggestion that the British minister should only be informed of the second point in the telegram, Günther gave him an account of the entire contents. Mallet reported immediately to the British Foreign Office the information that he had received from Günther and the Tokyo minister's assessment that there was "no doubt that this attempt must be considered as a serious one." 17 The Foreign Office shared this view. On September 24 the British minister to the United States, Lord Halifax, was instructed by the Foreign Office to inform US Secretary of State Cordell Hull. Hull agreed with a British proposal that the Swedish Foreign Ministry should be told that the Allies were not prepared to respond to indirect Japanese approaches. ${ }^{18}$

15 Bagge to Foreign Ministry, Telegram i Kl. I chiffer från Kungl. Maj:ts Beskickning i Tokio, no. 365-367, September 19, 1944. Politik: allmänt, Japan, 1944, aug.-jan. 1946, HP 39F, vol. 671 [henceforth: vol. 671], UD.

16 Personal communication from Berndt Fredriksson, Head, The Archive of the Foreign ministry, August 30, 1995.

17 Sir Llewellyn Woodward, British Foreign Policy in the Second World War (London: Her Majesty's Stationery Office, 1976), vol. 5, 50lf.

18 Ibid., 502. 
Allegedly, behind this peace proposal was Prince Konoe Fumimaro, the close relative of the Emperor and former prime minister, whom we have met in Chapter 3. Pondering the possibility of finding a neutral mediator for peace, Konoe had supposedly asked Suzuki to contact Bagge. Suzuki's idea was that Sweden should take action on its own initiative as a neutral country. ${ }^{19}$ According to the researcher Kobayashi Tatsuo, Konoe, in reality, knew nothing of all this. Suzuki only mentioned his name to attract Bagge's attention and add weight to the suggestion but he briefed Konoe about it afterwards. ${ }^{20} \mathrm{~A}$ week later, Bagge informed Stockholm, "Even the foreign minister is said to be considering the possibilities for peace." 21 This telegram was in a special code used when dealing with sensitive matters.

When Victor Mallet on September 30 met Erik Boheman, the undersecretary of state for foreign affairs, he was briefed about Bagge's telegram of September 27. Mallet told Boheman that Washington and London were not prepared to respond to indirect Japanese approaches but the Swedish minister "could reply if he wished that he knew it would be useless to deliver the Japanese message to us." 22 Later the same day, Boheman sent a telegram to Bagge and informed him, "Since we know from previous experiences that the English side does not respond to approaches that are not of an official character, we have not seen it suitable to pass on the message." 23 Thus, Bagge was kept in the dark about how the Foreign Ministry in Stockholm had handled his information.

Boheman's telegram was the first reaction from the Foreign Ministry in Stockholm to reach Bagge. The sensitive nature of the contents of this telegram is clear from the fact that it was kept in the same special safe, "the Yellow cupboard," as Bagge's telegram of September 19. According to Boheman, the telegram was "of considerable interest," and he asked Bagge to maintain the contact. This must have been reassuring for Bagge at the same time as it must have been a disappointment to learn that the Swedish Government had decided not to pass on a part of his information to the British authorities, as he had suggested in his telegram.

From other telegrams sent by Bagge to the Foreign Ministry in Stockholm during the coming months, it can be seen that he had met the Japanese foreign minister as well as the deputy foreign minister. This was natural since he was the dean of the diplomatic corps in Tokyo, but it also testified to his excellent contacts with the Japanese political leadership due to Sweden's role as Protecting

19 Letter from Suzuki Bunshirō to Shimomura Hiroshi, April 9, 1945, in Shüsen shiroku, vol. 2,113 .

20 Kobayashi Tatsuo, "Suēden o tsūjiru Taiheiyō sensō shūketsu kōsaku" [Maneuvers to end the Pacific War by way of Sweden], Kokugakuin högaku 18, no. 4 (February 1980), 97f.

21 Bagge to Foreign Ministry, Telegram i speciellt maskinchiffer från Kungl. Maj:ts Beskickning i Tokio, no. 381, September 27, 1944, vol. 671, UD.

22 Woodward, British Foreign Policy in the Second World War, 502.

23 Foreign Ministry to Legation Tokyo, Telegram i specialchiffer, no. 328, September 30, 1944, vol. 671, UD. 


\section{In the end}

Power for Japan, as explained in the previous chapter. In a cable on December 12, 1944, Bagge notified Stockholm that the Japanese Government was sincerely grateful for the actions taken by Sweden on behalf of Japan. ${ }^{24}$ In another telegram sent the same day, Bagge informed Stockholm about who was behind the approach mentioned in his telegram on September 19. "The individual referred to in my code 365 quarto first point resigned as prime minister two months before the war." Bagge also responded positively to the request to keep in touch with this person, but pointed out that it was "at present extremely sensitive and risky for the person concerned." ${ }^{25}$ On the telegram kept in the Swedish National Archives is jotted in pencil "this is Prince Konoe, who resigned 16 Oct. 1941." Other scribbled notes on the telegram suggest that Bagge's information was considered so vital that it had been brought to the attention of Foreign Minister Christian Günther.

The various meetings that Bagge had with peace-inclined Japanese seem to have provided renewed impetus to try to open the door to peace. In a telegram sent on April 3, 1945, Bagge referred again to the efforts that were being made toward peace. Based on his meetings and discussions in Tokyo, he reported that "unconditional surrender" was out of the question given Japanese views. For the Japanese, this concept meant disgrace and forcing it on them might lead to acts of desperation by the Japanese people. On the other hand, it was likely that far-reaching conditions reached through negotiations would be accepted. People realized that the war could not be won but, at the same time, believed that it impossible to defeat or occupy Japan. One could expect the Japanese to fight to the last man. A change in the Japanese constitution was out of the question. The Emperor was unassailable, but democratizing the power of the Emperor in much the same way as had happened in Britain with the King might be possible. The Institute of Pacific Relations had recently demanded the abolishment of the imperial family, which had caused apprehension and would certainly be an obstacle to any peace attempt. ${ }^{26}$

The day after Josef Stalin denounced the Soviet Neutrality Pact with Japan on April 5, Eric von Post, the head of the political section of the Foreign Ministry, conveyed Bagge's information to Herschel Johnson, the US minister

24 Bagge to Foreign Ministry, Telegram i Kl. I chiffer från Kungl. Maj:ts Beskickning i Tokio, no. 511, December 19, 1944, vol. 671, UD. In January 1945, Bagge reported that the Japanese foreign minister in his policy speech in the Japanese parliament on the 21 st had expressed Japan's gratitude to Sweden. See Bagge to Foreign Ministry, Telegram i Kl. II chiffer från Kungl. Maj:ts Beskickning i Tokio, no. 44, January 28, 1945, vol. 671, UD.

25 Bagge to Foreign Ministry, Telegram i Kl. I chiffer från Kungl. Maj:ts Beskickning i Tokio, no. 512, December 19, 1944, vol. 671, UD.

26 Bagge to Foreign Ministry, Telegram i Kl. II chiffer från Tokio, April 3, 1945, nos. 127128, vol. 671, UD. The Institute of Pacific Relations was an international nongovernmental organization that existed between 1925 and 1960, headquartered first in Honolulu then in New York, producing research on matters concerning Asia-Pacific. See Paul F. Hooper, "The Institute of Pacific Relations and the Origins of Asian and Pacific Studies," Pacific Affairs 61, no. l (1988). 
in Stockholm, who immediately forwarded it to the State Department. ${ }^{27}$ The next day he reported that Vilhelm Assarsson, the acting undersecretary of state for foreign affairs, had told him that the information that he had been given by von Post "represented views expressed to Swedish Minister Bagge in Tokyo by 'Jap officials of very high rank'." Johnson wrote further, "It is Foreign Office opinion although Bagge did not say so that these views were intentionally given to Bagge in the expectation they would come to [the] attention of United States and British Governments."28

In February 1945, Bagge met Sakaya Tadashi, a Japanese diplomat with whom he had become acquainted at the end of the 1920s. ${ }^{29}$ In early 1945, Sakaya returned from Finland where he had served as the minister. In his meetings with Bagge, Sakaya found that they had roughly the same view of the need for Japan to end the war. After their meeting in February, the two diplomats met more than ten times to discuss the prospects for peace. ${ }^{30}$

According to Sakaya's affidavit to the IMTFE, Bagge had volunteered his services as a token of gratitude for the help he had received during his years in Japan and asked whether Sakaya thought that Foreign Minister Shigemitsu Mamoru would agree to the Swedish Government sounding out US intentions concerning what most worried the Japanese: the security of the imperial family. ${ }^{31}$ Sakaya immediately informed Shigemitsu. According to Sakaya's later testimony, the foreign minister was very happy when he learned of Bagge's comment and asked Sakaya to write a memorandum and said that he wanted to meet Bagge. ${ }^{32}$ Sakaya's information made Shigemitsu add Bagge to three other possible channels for sending out peace feelers: approaching the UK through Japan's minister in Madrid, through Switzerland, and through the Vatican. ${ }^{33}$

A meeting between Bagge and Shigemitsu materialized shortly before the latter left as foreign minister when the Koiso government resigned on April 7. In his account of their meeting, Shigemitsu later wrote that

27 The Minister in Sweden (Johnson) to the Secretary of State, April 6, 1945, in U.S. Department of State, Foreign Relations of the United States (henceforth: FRUS), 1945, Diplomatic Papers, vol. 6: The British Commonwealth, The Far East (Washington, DC: U.S. Government Printing Office, 1969), 477.

28 The Minister in Sweden (Johnson) to the Secretary of State, April 7, 1945, in ibid.

29 Interview with Sakaya Tadashi, in Show ashi no tenno [The emperor in the history of the Shōwa period], ed. Yomiuri Shimbunsha, vol. 2 (Tokyo: Yomiuri Shimbunsha, 1967), $401 \mathrm{f}$.

30 Ibid., 402. In his affidavit at the IMTFE, Bagge mentions that he had met Suzuki several times after September 1944, but he does not give any indication of exactly how often they met. See Bagge affidavit, 34,560.

31 Sakaya affidavit, in IMTFE, Record of Proceedings, 1946-1948, 34,455f.

32 Sakaya, in Shöwashi no tennō, 402.

33 Miyasugi Hiroyasu, "Dainijitaisenki chūritsukoku Supein-Porutogaru de no Nihon no jōhō katsudō to gaikō-gunji e no eikyō" [The impact on Japan's intelligence activities and diplomacy and military affairs in the neutral Spain and Portugal during the Second World War], Takushoku daigaku kokusai Nibon bunka kenkyü l (2018), 34. 
Bagge was shortly returning to Sweden and readily offered to assist, saying, "I cannot bear to think of the ruin of Japan, which has such a 'glorious past'." After careful thought, I asked him to ascertain what peace terms the U.S. and Britain had in mind and to inform me through Okamoto, our Minister in Stockholm. I stipulated only that the terms must be consonant with the honour of Japan. ${ }^{34}$

According to Shigemitsu, Bagge "had agreed to mediate on his return to Stockholm." ${ }^{35}$ What Bagge told the IMTFE in his affidavit was that Shigemitsu "requested me very earnestly to do whatever I could to find out the possibilities for peace." Shigemitsu had also asked Bagge to collaborate with Japan's minister in Stockholm, Okamoto Suemasa, who was then to report to Tokyo. ${ }^{36}$ For reasons that are not clear, Bagge waited until April 11 to report to the Swedish Foreign Ministry:

Telegram in machine code from Tokyo

Sent $11 / 41945$ at 1100

Arrived 11/4 1945 at 1245

I have kept in touch with my political friend-your 328-and repeatedly discussed the situation and the peace problem. He has also had useful contacts within the government and recently informed the foreign minister about our talks. At my farewell visit with Shigemitsu he dealt with the subject during our hour-long conversation along similar lines. Asked for my sincere opinion I did not hide that I believe the war is lost for Japan and that continued fighting would only ruin the country and the people without changing the outcome. The foreign minister did not object to this. He emphasized the emperor's desire for peace and hinted at his wish to bring an end to the war with the inevitable sacrifices. He expressed his sincere trust and asked me to participate in producing a proposal for an acceptable solution. He asked that after my return [to Sweden] I should cooperate with Okamoto to this end and in the interest of peace.

A representative of Shigemitsu visited me today and emphasized that the matter was urgent and that Okamoto had been informed about the contents of our conversation. Based on this, Okamoto should shortly bring up this subject with His Excellency.

Bagge $^{37}$

34 Shigemitsu, Japan and Her Destiny, 339.

35 Ibid., 355; cf. Sakaya affidavit, 35,455f.

36 Bagge affidavit, in IMTFE, Record of Proceedings, 1946-1948, 34,561. The gist of the meeting is described in the letter from Suzuki to Shimomura, April 9, 1945, referred to above.

37 Bagge to Foreign Ministry, Telegram i maskinchiffer från Tokio, no. 133-134, April 11, 1945, vol. 671, UD. 
The day for Bagge's return to Sweden was approaching and he sent a new telegram on April 12 to Stockholm, obviously to wind up and organize the information he had received before he left for Sweden. He referred to his telegram the previous day and indicated that he now wanted to present "some summarizing impressions." The telegram was less specific than the one he had sent the day before as to who were the actors on the Japanese side. In the later telegram, Bagge ascribed the opinions expressed to an unspecified agent, "man"-which can be interpreted as "the Japanese," "Japan," "his discussion partner (or partners)," etc. Interpreted literally, it indicates that the peace feeler was broaderbased than he had reported earlier.

Initially, Bagge noted that there was a strong desire in Japan for a negotiated peace settlement. However, the Japanese were not going to take any initiative as it could be interpreted as a sign of weakness. Therefore, help was needed to get negotiations started, and the Japanese would be pleased if proposals from the Swedish side were presented or, at least, information was obtained about the views of the counterpart. Above all, they hoped for UK understanding; in certain quarters it was found regrettable that war had ever been declared against the UK, which was seen as unnecessary and unwise. They counted on English war fatigue and worries over US successes in the Pacific Ocean that had put the UK in the back seat. On the other hand, the Japanese were prepared to continue to the bitter end, if acceptable conditions were not offered. Bagge noted that his conversation with Shigemitsu had confirmed his conclusions in his telegram on April 3. He added that it was believed that the Americans at this stage must understand how exceptionally costly a decisive victory would be and that even the United States might, therefore, prefer to discuss conditions that would not humiliate the Japanese with their strong national pride, rather than continue the bloodshed. ${ }^{38}$

It is clear from notes in pencil on the telegram kept in the Swedish National Archives that the information conveyed by Bagge was handled at the highest level in the Swedish Foreign Ministry. Three passages must have caught the attention of the ministry officials. One was the eagerness on the part of the Japanese to reach a negotiated peace, the reported inviolability of the Emperor, and the fact that the Japanese foreign minister had explicitly asked Bagge to participate in bringing about an acceptable solution. The reason for Bagge's and Sweden's involvement was said to be that it would make it possible for Japan to avoid taking any initiative which might be interpreted as a sign of weakness. At the same time, the officials could probably not help noticing the shift of emphasis in his telegrams of April 11 and 12. In the first telegram, he reported that the foreign minister had expressed his trust in Bagge and asked him to participate in bringing about an acceptable solution and to cooperate with the Japanese minister in Stockholm. In his later telegram, Bagge reported that his Japanese contacts

38 Bagge to Foreign Ministry, Telegram i Kl. I chiffer från Tokio, no. 137-138, April 12, 1945, vol. 671, UD. 
wanted Sweden to be active, which had been the main message in his telegram of September 19.

The shift of emphasis in the contents of the two telegrams may be connected to the fact that Bagge had met Sakaya the same day. It is not clear exactly when Bagge sent the second telegram but as it arrived in Stockholm on April 13 at $1 \mathrm{pm}$, it seems likely that he finalized it after his meeting with Sakaya, who had come to him to report the views of the new foreign minister, Tōgō Shigenori. In his meeting with Tōgō on April 9, Sakaya gave the impression that Shigemitsu had stopped short of making a formal request for mediation, and simply asked the Swedish Government to sound out US intentions at "its own instance." No meeting between Tōgō and Bagge took place before the envoy departed for Sweden, but the new foreign minister's positive views were conveyed to Bagge in no uncertain terms by Sakaya. He informed Bagge that the new foreign minister's stance to the peace question was the same as his predecessor ${ }^{39}$ According to Sakaya, Bagge "looked very much delighted" when he was informed of Tōgō's stance. $^{40}$

On the copy of the telegram of April 12 in the Swedish National Archives, it is noted in pencil that Foreign Minister Shigemitsu "resigned at the beginning of April 1945; the new is Togo (former ambassador to Moscow)." This information created uncertainty as to whether or not the information Bagge had sent to Stockholm was still valid. Shigemitsu had resigned on April 7, the new foreign minister had assumed his duties two days later, and Stockholm knew about the conflicting views among Japan's political leadership. In another telegram to Stockholm the next day, sent immediately before Bagge departed from Haneda, the envoy reported that the Japanese Foreign Ministry "has informed me that he [Tōgō] has been briefed about of my conversation with Shigemitsu and that the change of government does not mean any change of the approach to the question we have been discussing." ${ }^{41}$ His telegram must have assuaged some of the uncertainties about Japan's moves in the immediate future.

The Swedish Foreign Ministry certainly noted Shigemitsu's shift of focus from Bagge to Sweden, which activated the neutrality reflexes of the ministry. They had come to the fore shortly before. In February 1945 the German foreign minister, Joachim von Ribbentrop, had launched a plan to negotiate a separate peace with the Soviet Union. This initiative was effectively killed when the head of the political section of the Swedish Foreign Ministry, Erik von Post, clarified Sweden's disinterest in taking part in establishing the necessary contacts in what was seen as futile plans for a separate peace. ${ }^{42}$ A key consideration was that the United States

39 Bagge affidavit, 34,562f.

40 Sakaya affidavit, 35,457 .

41 Bagge to Foreign Ministry, Telegram i Kl. II chiffer från Tokio, no. 143, April 13, 1945, vol. 671, UD. According to Bagge, it was Sakaya who was the messenger, see Bagge affidavit, 34,562 .

42 Erik von Post, head of the political section, Foreign Ministry, to Arvid Richert, Swedish minister to Berlin, personal letter [Handbrev], March 12, 1945, as quoted in Leif Leifland, 
had made it clear that it did not appreciate any German peace feelers. ${ }^{43}$ It was an overriding concern of the Swedish Government to nurture good relations with the Allied Powers. The Swedish Government abstained from poking its nose into the business of the Great Powers. Swedish actions had to be tolerable to all sides for Stockholm to agree involving itself. This had been the case when Sweden got involved in bringing about peace between Finland and the Soviet Union. ${ }^{44}$ As far as royal interventions were concerned, in fresh memory was the disastrous outcome of King Gustaf V's effort in 1940 to mediate between Hitler and Georg VI, which became so embarrassing for Sweden and the Swedish Government that no one wanted to bring it up afterwards. ${ }^{45}$

A reason for the Swedish Foreign Ministry to proceed cautiously was its distaste for doing anything that the Allied Powers would see as not compatible with their vital interests. The US and UK Governments had declared that they were not interested in anything but a Japanese unconditional surrender and this could not be ignored. The Allied war efforts against the Japanese had produced significant successes and the United States was preparing for an all-out effort to take on Japan once Germany was defeated. The response of the Foreign Ministry to what Bagge reported in his telegrams of April 11 and 12 was conveyed in a telegram to him on April 14. It was short and could not be misunderstood: "No initiative Sweden either regarding proposals or information." ${ }^{46}$ Bagge is certain to have noted that while Sweden would not act in any way, nothing was said about his role. When this message reached him is, however, not clear. The telegram is dated April 14 and by that time he had already left Japan on a special flight arranged by the Gaimushō taking him to Manchukuo from where he embarked on the TransSiberian Railway.

\section{Diplomats in action in Stockholm}

Bagge reached Stockholm on May 10. His first duty after his arrival should have been to report to Foreign Minister Christian Günther, but conscious of the role he had been assigned by Shigemitsu, Bagge instead first called Minister Okamoto Suemasa and asked for an immediate confidential meeting. He rushed from the

General Böhmes val: Sverige och det nazistiska Tyskland vairen 1945 [General Böhme's choice: Sweden and Nazi Germany, Spring 1945] (Stockholm: Norstedt, 1992), 29.

43 Kent Zetterberg, "Svensk säkerhetspolitik i krigsslutet och inför det nya Europa 1945" [Swedish security policy at the end of the war and encountering the new Europe 1945], in Horisonten klarnar: 1945 - krigsslut [The horizon dawns - the end of the war], eds. Bo Huldt and Klaus-Richard Böhme (Stockholm: Svenskt Militärhistoriskt Bibliotek, 2002), 179.

44 The predicament is described in Alf W Johansson, Per Albin och kriget [Prime minister Per Albin Hansson and the war] (Stockholm: Tiden, 1984), chapter 16.

45 Until the embarrassment lifted, McKay was one of the few who brought up Gustaf V's attempt at mediating, see C.G. McKay, From Information to Intrigue: Studies in Secret Service based on the Swedish Experience, 1939-1945 (London: Frank Cass, 1993), $208 \mathrm{f}$.

46 Foreign Ministry to Bagge, Telegram i Kl. I chiffer, April 14, 1945, vol. 671, UD. 
ferry to the Japanese legation, eager to discuss his role as a go-between to the Allied Powers with Okamoto. He had left Tokyo before the telegram arrived and the sensitivity of the topic was such that the ministry had most likely been unable to convey the information to him when he was on his way to Stockholm. This indicates that he was still in the dark about the Foreign Ministry decision taken in mid-April in which the Swedish Foreign Ministry discarded any involvement in Japan peace matters.

The two diplomats met at the Japanese legation at 11 o'clock. Bagge expected to enter into serious talks with Okamoto about how to work for peace for Japan, which Shigemitsu had discussed with him, and which he knew that Shigemitsu's successor Tōgō supported. According to Bagge's affidavit to the IMTFE:

I asked him [Okamoto] whether he had received any confidential telegrams about efforts to negotiate peace and I told him that I had several serious talks with Mr. Shigemitsu as Foreign Minister before leaving Japan. I told him that Mr. Shigemitsu had been very frank and had asked me to make a peace feeler. Mr. Okamoto replied that this was a very serious matter but that he had not heard anything about it. [...] I asked Mr. Okamoto to make inquiries as to whether or not I should continue my work on this peace effort. Mr. Okamoto said that he would send a telegram. ${ }^{47}$

Okamoto's subsequent report to Foreign Minister Tōgō the same day was much less specific about what Bagge had brought up, as it was described as "the matter brought up by Minister Sakaya." This vagueness was likely a precaution considering the top-secret nature of the matter. Okamoto stressed that, if the intention was that the Swedish Government was to pursue peace negotiations wholly on its own initiative, it was necessary to be able to confidentially confirm this to Bagge. ${ }^{48}$

When Bagge met Foreign Minister Christian Günther, the topics of their exchange remain guesswork as no notes were taken. ${ }^{49}$ Given the situation, a few topics must have been in focus: Sweden's stance vis-à-vis the Japanese interest in a Swedish mediation, the situation in Japan, and the Japanese interest in a role

47 Bagge affidavit, 34,563.

48 Okamoto to Tōgō, Telegram, no. 950, May 10, 1945, in Nihon gaikō bunsho dejïtaru korekushon, Taibeiyō sensō [Digital collection of Japanese diplomatic documents: The Pacific War] (2017), ed. Gaimushō, vol. 3, https://www.mofa.go.jp/mofaj/annai/honsho/shiryo/ archives/pdfs/taiheiyo3_03.pdf, accessed April 11, 2019.

49 Günther did not have the habit of writing down what he said or did in various contexts according to his closest collaborator, see Erik Boheman, På vakt: Kabinettssekreterare under andra världskriget [On guard: As undersecretary of state for foreign affairs during the Second World War] (Stockholm: Norstedt, 1964), 40. Another senior foreign ministry official, Sverker Åström, claims that Günther seldom gave an account for his talks with others, see Sverker Åström, Ögonblick: Från ett halvsekel $i$ UD-tjänst [Moments: From half a century in the foreign ministry] (Stockholm: BonnierAlba, 1992), 104. 
for Bagge. As to the first topic, the decision had been taken a month before. The Swedish Government was not prepared to take any initiative. For Günther, it was out of the question that Sweden would become involved in any Japan imbroglio. However, he knew that the US Government should be informed. On April 19, US Secretary of State Edward Stettinius had sent a message to his minister in Stockholm, Herschel Johnson, about the information the Swedes had provided in early April:

Although the Department desires that the Legation show no interest or take any initiative in pursuit of the matter because to do so might be misconstrued as indicating room for modification of this Government's demand for unconditional surrender, there would be no objection if, in reference to this or future communications of this nature, the Legation as on its own initiative were to express orally its own thanks for the courtesy of the Swedish Government in the matter. ${ }^{50}$

The message revealed that the US disinterest in anything but Japanese unconditional surrender did not mean a lack of US interest in being informed of Japanese approaches. It indicated that if any such moves were noted, the US Government was interested in knowing about them. ${ }^{51}$ This made it urgent to pass on Bagge's information and Günther made immediate arrangements for a lunch to which he invited Johnson and Bagge.

The hastily arranged lunch took place on April 12.52 Johnson reported to Washington three days later what proceeded during the lunch. Bagge had talked about the possibility of Soviet entry into the war and said that the Japanese would never accept unconditional surrender. They would rather commit national suicide, especially if the Japanese imperial institution would be attacked. Johnson's response had been to point out that the United States would never allow Japan to put up conditions. ${ }^{53}$

This report clarifies three matters. First, Bagge had not in any way touched upon the Japanese interest in a Swedish involvement in a peace effort or the significant role that influential Japanese had assigned to him. This was maybe not

50 The Secretary of State to the Minister in Sweden (Johnson), April 19, 1945, FRUS 1945, vol. 6,478 .

51 The same way of acting can be noted on the British side. See Foreign Office to British legation, Stockholm, Telegram, April 26, 1945, Japanese surrender. Code 23 File 630 (to paper 5179), FO 371/46453, The National Archives, London.

52 The date of the lunch is noted in Herschel V. Johnson, Series 6. Additions, Folder 371, Planner 1945, Herschel Vespasian Johnson Papers, 1880-1969, Wilson Library, University of North Carolina at Chapel Hill. I am grateful to Mr Matthew Turi, Manuscripts Research and Instruction Librarian, who checked Herschel Johnson's papers.

53 Herschel Johnson, Telegram, no. 1798, May 15, 1945, as summarized in Gerhard Krebs, "Aussichtslose Sondierung: Japanische Friedensfühler und schwedische Vermittlungsversuche 1944/45," Viertelsjahrbefte für Zeitgeschichte 45, no. 3 (July 1997), 440. 
so surprising because at the dinner he was sitting next to his boss who had categorically rejected any Swedish involvement in Japanese peace overtures. Second, Johnson's comment that the United States would not allow Japan to put up conditions can be seen as a veiled criticism of Bagge's stance. The Swedish Foreign Ministry had briefed the US legation in Stockholm about Bagge's past reporting from Tokyo, so Johnson was aware that Bagge had spoken up for Japan's interest. Third, Günther does not figure in Johnson's report. Given that the Swedish foreign minister is known as a very skilled and experienced diplomat, his way of acting, first bringing together Bagge and Johnson and then making Bagge do the talking was a way to demonstrate that as far as Japan peace matters were concerned, the Swedish Government was not involved.

Two days later Bagge learned at the Foreign Ministry that Japan's military attaché in Stockholm, Onodera Makoto, had launched a move similar to the one Bagge had been entrusted with. ${ }^{54}$ The Swedish businessman Eric Erickson, who had been on the blacklist in London, had been asked by Onodera to try to establish contacts with the US and UK ministers in Stockholm. In order to establish these contacts, Onodera had asked Erickson to approach Prince Carl Senior, a brother of the king. In a meeting with the prince's chamberlain Gustaf Crispin Löwenhielm, Erickson asked if the prince as the chairman of the Swedish Red Cross "in some way could fix (mediate) the contact that General Onodera wished with the US and English ministers here." 55

On April 16 Bagge met with Okamoto, who reported to Foreign Minister Tōgō the following day. According to Okamoto, Bagge had without further ado brought up Onodera's move and told him that the Swedish Foreign Ministry had immediately (sokuza ni) rejected it as an interference of no value. A military attaché could not take such an action on such an important matter and, not only that, the ministry found the move clumsy. Bagge warned that if Onodera continued his activities, it would disturb the main thread [the Bagge track] and become very dangerous. ${ }^{56}$

A strictly confidential memo in the Swedish Foreign Ministry archive confirms Okamoto's report that the prince had immediately informed the Foreign Ministry about Onodera's request and that the ministry had equally immediately rejected

54 The date is based on that Okamoto reported to Tokyo that Bagge had told him when they met on May 16 that he had been informed "the day before yesterday." See Okamoto to Tōgō, Telegram, no. 952, May 17, 1945, in Nihon gaikō bunsho dejitaru korekushon, Taiheiyō sensō (2017), ed. Gaimushō, vol. 3.

55 Prince Carl Senior, "PM" [Memo], May 10, 1945, Vapenstillestånd och fred, HP 39F, vol. 1637 [henceforth: vol. 1637], UD, vol. 1637, UD.

56 Okamoto to Tōgō, May 17, 1945. The Okamoto version of what took place in May 1945 referred to in Japanese history writing often relies on a memo he wrote in 1951, presented in, for example, Shüsen shiroku, 122f. When he wrote this memo, he does not seem to have refreshed his memory by rereading the telegrams he sent to Foreign Minister Tōgō immediately after his meetings with Bagge in May 1945. In Okamoto's first telegram sent on May 10, 1945, he reported correctly that the Swedish businessman Eric Erickson and Prince Carl Senior were involved; in his 1951 memo the two Swedes are said to be "a German businessman" and Prince Carl Junior, both claims erroneous. 
the proposal. ${ }^{57}$ This response should not be a surprise as it was based on the government's decision in mid-April how to handle Japanese overtures. A month later it was even less reason to act on a proposal from an inveterate Nazi friend on behalf of a Japanese general. Nazi Germany had just been defeated by the Allied Powers, and they were not interested in anything but the unconditional surrender of the last remaining enemy, Japan. That Onodera's proposal had not only been discarded by the Foreign Ministry but that this was also communicated to the Japanese side is corroborated by another jotting, added by hand to the strictly confidential memo in the Foreign Ministry archive: "Bagge advised the Japanese minister to have General Onodera end further contact searching." Thus, as it takes two to tango and the Swedish side was not interested in Onodera's invitation, his move was terminated so quickly that it had hardly begun. ${ }^{58}$

Having informed Okamoto that Onodera's move had been discarded, Bagge went on to ask if Okamoto had received any response from Tokyo about his own action but was told this was not the case. According to Bagge, they needed to know Tōgō's view, which meant that they had to wait for a while. However, when Okamoto asked Bagge if he had had contact with the British and Americans in Stockholm, Bagge told him that he had met the US minister and had reported objectively about what he had observed about the situation in Japan. He had done so as someone who had worked for about ten years in the country and was a friend of Japan. ${ }^{59}$

What Bagge told Okamoto is striking in two respects. First, despite that Bagge knew by now that his government had rejected taking any initiative whatsoever vis-à-vis Japanese peace overtures, he did not inform Okamoto of the official decision. Instead, he queried whether anything had been heard from Tokyo. This might be because Bagge still believed that he could function as an intermediary between Japan and the United States and the United Kingdom because the warring parties lacked channels of communication. His role continued to be potentially important. Second, it is evident that Bagge overplayed his hand in his encounter with Johnson. Their meeting allowed Bagge to impress on a leading US diplomat his capacity as a diplomat, but he missed this chance. Although he might be seen as a suitable mediator in Japanese eyes, a go-between has also to be acceptable to the other party. Presenting Johnson with an "objective" view is what can be expected from a diplomat but talking as "a friend of Japan" at a meeting with the top diplomat in Stockholm representing Japan's No. I enemy in the ongoing war did not impress Johnson as was shown by his veiled criticism of Bagge.

57 Strictly confidential foreign ministry memo, typed, unsigned (May 10, 1945?), vol. 1637, UD. The date has been added by hand.

58 For a detailed analysis of "the Onodera peace feeler" based on Japanese sources as well as on wartime documents in Swedish archives, see Bert Edström, The Untold Story of Onodera Makoto and Swedish Intelligence: "They acted as I expected": The Surveillance of Japan's Military Attaché and His Intelligence Work 1941-1945, (forthcoming), chapter 8.

59 Okamoto to Tōgō, May 17, 1945. 


\section{In the end}

On the Japanese side, Foreign Minister Tōgō's concerns must have increased when he read Okamoto's telegram of May 17. When Bagge was still in Tokyo, Sakaya had told Tōgō that the Swedish Government would work on its own initiative. What he had learned from Okamoto about his meeting with Bagge on May 10 was different-if the intention was that the Swedish Government was to pursue peace negotiations wholly on its own initiative, it was necessary to confidentially confirm this to Bagge. This would require preparations within Japan, for the simple reason that the hard-liners within the army were not willing to allow Japan to take part in something tantamount to admitting that the war was lost. Unconditional surrender that the Allied Powers requested was out of the question. "Had such a move been made," Paul Kecskemeti concluded in his analysis of the diplomatic moves in the final stage of the war, "the extremist elements of the Army, among whom the mystique of the 'holy war' for Japan held unlimited sway, would have staged a coup d'état." ${ }^{60}$ In such an event, not even the members of the government would have been safe. Kase Toshikazu claimed in his book about the end of the war that it was "extremely difficult and dangerous, for in those days even the foreign minister's contacts with foreign envoys were apt to invite the suspicions of the vigilant military police." ${ }^{11}$ To anyone pursuing a peace option, a warning of what could happen had been given when hundreds of people were arrested in April on suspicion of harboring anti-war sentiments. ${ }^{62}$

A major consideration on the Japanese side all along had been that any Swedish intervention should be made as if Sweden were acting on its own initiative so that Japan might avoid showing any kind of weakness. Tōgō had to be careful. What Bagge told Okamoto about his meeting with Johnson might not be all that took place. If it were revealed that an attempt to establish contact with the enemy was backed by influential Japanese, even a member of the Japanese Government, the army hard-liners would ruin whatever prospects the budding peace endeavor might have. Therefore, Tōgō's response to Okamoto on May 18 was noncommittal: "What happened during the previous government needs to be investigated carefully and this will take time." 63 Tōgō's response was a signal that the Bagge kosaku had been abandoned also by the Japanese side.

\section{Concluding remarks}

When the war began to turn into a disaster for Japan, various peace proposals were mooted. However, as US Acting Secretary of State, Dean Acheson, testified at the end of 1945, "there is no evidence of any peace offer or of any statement looking toward peace transmitted to this Government before 10 August 1945,

60 Paul Kecskemeti, Strategic Surrender: The Politics of Victory and Defeat (New York: Atheneum, 1964), 174.

61 Toshikazu Kase, Journey to the Missouri (New Haven: Yale University Press, 1950), 220.

62 One of those arrested was Yoshida Shigeru, who became prime minister in 1946.

63 Tōgō to Okamoto, Telegram, no. 953, May 18, 1945, in Nihon gaikō bunsho dejitaru korekushon, Taiheiyō sensō (2017), ed. Gaimushō, vol. 3. 
from official Japanese sources or from any person authorized to act as an agent for the Japanese Government." ${ }^{64}$ Acheson's claim is not entirely correct as "the Bagge peace feeler" had the backing of Foreign Minister Shigemitsu and his successor Tōgō, at least initially.

In standard treatises on Japanese foreign policy, Tōgō is seen as the one who discarded the attempt to take advantage of Bagge to open a channel to the United States and the United Kingdom. ${ }^{65}$ A recent standard work claims, "Shigemitsu displayed some interest, but Togo, who succeeded him, was skeptical and terminated the overtures." ${ }^{\prime 6}$ As we have seen, this does not square with what happened. Initially, Tōgō was positive to Bagge as an intermediary. The Swede was informed of this shortly before he left Japan. Later, Tōgō's stance changed as was revealed by his telegram to Okamoto on May 17. The reasons are not entirely clear. Bagge's immediate reaction was that it lay with Tōgō's "strong position in Moscow since the time he was Japanese Ambassador there." ${ }^{67}$ Shigemitsu wrote in his recollections: "Togo put a stop to any possible activities by saying that the Cabinet had changed in the meantime. Presumably, he had more faith in a continuation of existing relations with Russia." ${ }^{68}$ In his early account, Kase claimed, "throughout the Pacific War our main diplomatic endeavors were concentrated upon Moscow, creating a sort of habit of mind which, I think, partly explains why we chose the Soviet government as the channel for addressing the Allied powers prior to our surrender." 69

Shigemitsu's claim that Bagge had agreed to be a mediator on his return to Stockholm is consonant with Tōgō's view. Tōgō had been led to believe that Sweden was willing to sound out the United States and the United Kingdom, but this does not fit what Bagge reported to the Swedish Foreign Ministry. In his telegram of September 19, 1944, he reported what amounted to a peace feeler, not towards the Allied Powers but singling out the UK as the counterpart for an agreement with the initiative being Japanese. In his telegram of April 11, 1945, he reported that he had been asked by Shigemitsu "to participate in bringing about a proposal for an acceptable solution" and to that end to "cooperate with Okamoto for this purpose and in the interest of peace." The stance taken by the Swedish Foreign Ministry was that Sweden was not going to take any initiative,

64 The Acting Secretary of State [Dean Acheson] to Representative Bertrand W. Gearhart, of California, December 18, 1945, FRUS, 1945, vol. 6, 4966 .

65 See, e.g., Fujiwara Akira, "Haisen” [Japan's defeat], in Iwanami kōza: Nihon rekishi, vol. 21: Kindai [Iwanami series: A history of Japan, vol. 21: The modern period, 8] (Tokyo: Iwanami shoten, 1977, 350; Nihon gaikō hyakunen shōshi, ed. Gaimushō, 230f; Ōhata Tokushirō, Nihon gaiköshi [A Japanese diplomatic history] (Tokyo: Azuma shuppan, 1978), 200.

66 Ikeda Kiyoshi, "Anglo-Japanese Relations, 1941-1945," in The History of Anglo-Japanese Relations, 1600-2000, vol. 2: The Political-Diplomatic Dimension, 1931-2000, eds. Ian Nish and Yoichi Kibata (New York: St. Martin's Press, 2000), 129.

67 Bagge affidavit, in IMTFE, Record of Proceedings, 1946-1948, 34,564.

68 Shigemitsu, Japan and Her Destiny, 355.

69 Kase, Journey to the Missouri, 166. 
neither regarding proposals nor information. At the same time, the ministry had asked Bagge to keep in touch with his source, which indicated an active interest in the action he was involved in.

The British historian Richard Storry contacted Bagge in 1960 to get his comments about what took place in the final phase of the war. ${ }^{70}$ Bagge's response clarifies how he looked at matters in hindsight. In his letter, Storry brought up Onodera's move, which Storry believed had "complicated things for you." comment was natural as although Bagge's and Onodera's peace endeavors were separate and not at all interrelated, they were occasionally mixed up. ${ }^{72}$ According to Bagge, Storry's impression was not entirely without foundation: "The efforts made by General Onodera were certainly not very fortunate, but I do not think they did any real harm." Bagge went on to describe how Shigemitsu at their meeting had been

very frank and outspoken and there was no question of any 'veiled intimation' as $\mathrm{Mr}$ Kase puts it in his book. We readily agreed upon the general lines of how to proceed. That there had to be concessions from the Japanese side was evident, but Mr Shigemitsu did not specify. As he says in his memoirs: "I stipulated only that the terms must be consonant with the honour of Japan."73

The most important clarification made by Bagge dealt with the mission he had accepted to shoulder:

In the collection of documents published by Gaimusho [Shisen shiroku] there are two erroneous and misleading passages that I should like to point out. From the statement of Mr Tadashi Sakaya as well as from the one attributed to $\mathrm{Mr}$ Shigemitsu himself one must get the impression that I did propose myself to act as mediator for peace negotiations. This is quite wrong and you will see from what I have written above that all the time my attitude was carefully reserved, although I was prepared to act for the good sake when I was asked to do so. ${ }^{74}$

70 The contact resulted in an exchange of letters: Storry to Bagge, February 25, 1960; Bagge to Storry, March 9, 1960; and Storry to Bagge, March 9, 1960. Copies of the letters exchanged were handed over to the author by Ambassador Erik von Sydow in 1996. He had received the material in 1974 from the British historian Louis Allen, who had asked von Sydow to comment on a prospective book chapter about the Bagge kosaku. Personal communication from Erik von Sydow, April 21, 1996.

71 Richard Storry to Widar Bagge, Letter, February 25, 1960, copy in the author's private collection.

72 Author's interview with Mrs Onodera Yuriko, Tokyo, June 14, 1991.

73 Widar Bagge to Richard Storry, Letter, March 9, 1960, in Collected Writings of Richard Storry, ed. Ian Nish (London: Routledge, 2002), 150-152.

74 Ibid. 
While Bagge argued that "all the time my attitude was carefully reserved" and that he had not proposed himself "as mediator," he also claimed that he had been "prepared to act for the good sake when I was asked to do so." Thus, what he explicitly denied was that he had proposed himself as mediator. He was prepared to shoulder the responsibility if asked. But just at the moment when he had the opportunity to boost his putative role as an intermediary, his lack of understanding of what was needed from such a go-between became obvious. The question is why he ruined any prospects by overplaying his hand when he met Johnson? Maybe it is explained by an observation made by a Swedish foreign-policy insider about three diplomats named Bagge, who were working at the Swedish Foreign Ministry at the same time. According to the insider, they were called Big Bagge, Medium Bagge, and Little Bagge, in the order of ability. Unfortunately, the insider said, Widar was Little Bagge. ${ }^{75}$ What took place when Bagge met Johnson seems to confirm how the insider characterized Sweden's former envoy to Japan.

Bagge was only too aware of his failure and admitted it to a Japanese correspondent in Stockholm in the final phase of the war. ${ }^{76}$ Yet in hindsight, he recollected with affection the short period in May 1945 when "Japan's national fate was decided" and he had been a participant in the Great Power game that decided the fate of nations and liked to talk about it. ${ }^{77}$ When he was offered the post of envoy to Cairo after Tokyo, he was not enthusiastic. ${ }^{78}$

\section{References}

\section{Unpublished}

Kungliga biblioteket [National Library of Sweden]

Östen Undéns samling

Privata dagböcker, I (27/6 1945-27/9 1946) [Private diaries, vol. 1 (June 27, 1945-September 27, 1946)], L108

75 Personal communication from Ambassador Kaj Björk, October 13, 1999. Björk was a central figure in Swedish politics from 1945 in various capacities, the editor-in-chief for a period of the Social Democratic theoretical organ, Tiden, and later the editor-in-chief of Social Democratic newspapers, a member of the Riksdag, an advisor to Foreign Minister Torsten Nilsson, and ambassador to China and Canada.

76 Ena Takio interview in Shögen: Watashi no shöwashi [Testimony: My Shōwa history], ed. Tōkyō 12 channeru hōdōbu, vol. 5 (Tokyo: Gakugei shorin, 1969), 69.

77 When Gunnar Jarring was stuck in Cairo for three weeks in 1946 on his way to his posting as acting chargé d'affaires in Addis Ababa, he had ample opportunities to listen to Bagge, who often talked about his Tokyo years. Personal communication from Gunnar Jarring, September 5, 1994.

78 Foreign Minister Östen Undén noted in his diary on September 17, 1945: “Offered diplomatic postings—-generally met with sour looks. Bagge from Tokio accepted reluctantly Cairo.” See Östen Undén, Privata dagböcker, I (27/6 1945-27/9 1946) [Private diaries, vol. 1 (June 27, 1945-September 27, 1946)], L108, Östen Undéns samling, Kungliga Biblioteket [National Library of Sweden]. 
Utrikesdepartementets arkiv 1920 års dossiersystem, Riksarkivet [The archive of the Foreign Ministry, Filing system of 1920, Swedish National Archives]

HP 39F, vol. 671, Politik: allmänt, Japan, 1944, aug.-jan. 1946

HP 39F, vol. 1637, Vapenstillestånd och fred

Pl Widar Bagge, vol. 2

Pl Erik von Sydow

The National Archive, London

FO 371/46453, Japanese surrender. Code 23 File 630 (to paper 5179)

Wilson Library, University of North Carolina at Chapel Hill

Herschel Vespasian Johnson Papers, 1880-1969

Herschel V. Johnson, Series 6. Additions, Folder 371, Planner 1945

Author's private collection

Richard Storry, Letter to Widar Bagge, February 25, 1960

Wilhelm Carlgren, Letter to Erik von Sydow, October 13, 1974

Author's interview with Mrs Onodera Yuriko, Tokyo, June 14, 1991

\section{Published}

Åström, Sverker. Ögonblick: Från ett halvsekel $i$ UD-tjänst [Moments. From half a century in the foreign ministry]. Stockholm: BonnierAlba, 1992.

Bagge, Widar. "Letter to Richard Storry, 9 March 1960." In Collected Writings of Richard Storry, edited by Ian Nish, 150-152. London: Routledge, 2002.

Boheman, Erik. På vakt: Kabinettssekreterare under andra världskriget [On guard. As the state secretary for foreign affairs during the Second World War]. Stockholm: Norstedt, 1964.

Carlgren, Wilhelm M. Svensk utrikespolitik 1939-1945 [Swedish foreign policy, 19391945]. Stockholm: Allmänna Förlaget, 1973.

Carlgren, Wilhelm M. "Die Mediationstätigkeit in der Außenpolitik Schwedens während des Zweiten Weltkrieges." In Schwedische und schweizerische Neutralität im Zweiten Weltkrieg, edited by Rudolf L. Bindschedler, Hans Rudolf Kurz, Wilhelm Carlgren, and Sten Carlsson, 97-110. Basel, Frankfurt am Main: Helbing und Lichtenhahn, 1985.

Edström, Bert. "The Untold Story of Onodera Makoto and Swedish Intelligence: "They acted as I expected": The Surveillance of Japan's Military Attaché and His Intelligence Work 1941-1945 (forthcoming).

Fujiwara Akira. "Haisen” [Japan's defeat]. In Iwanami kōza: Nihon rekishi, vol. 21: Kindai [Iwanami series: A history of Japan, vol. 21: The modern period, 8], 322370. Tokyo: Iwanami shoten, 1977.

Hooper, Paul F. "The Institute of Pacific Relations and the Origins of Asian and Pacific Studies.” Pacific Affairs 61, no. 1 (1988), 98-121.

Ikeda, Kiyoshi. "Anglo-Japanese Relations, 1941-1945." In The History of AngloJapanese Relations, 1600-2000, vol. 2: The Political-Diplomatic Dimension, 
1931-2000, edited by Ian Nish and Yoichi Kibata, 112-134. New York: St. Martin's Press, 2000.

International Military Tribunal for the Far East (IMTFE). Affidavits by Widar Bagge and Sakaya Tadashi. Record of Proceedings, 1946-1948. Washington, DC: Library of Congress, 1974.

Jarring, Gunnar. Memoarer 1939-1952 [Memoirs, 1932-1952]. Stockholm: Bonnier, 1981.

Johansson, Alf W. Per Albin och kriget [Prime minister Per Albin Hansson and the war]. Stockholm: Tiden, 1984.

Kase, Toshikazu. Journey to the Missouri. New Haven: Yale University Press, 1950.

Kecskemeti, Paul. Strategic Surrender: The Politics of Victory and Defeat. New York: Atheneum, 1964.

Kobayashi, Tatsuo. "Suēden o tsūjiru Taiheiyō sensō shūketsu kōsaku" [Maneuvers to end the Pacific War by way of Sweden]. Kokugakuin högaku 18, no. 4 (February 1980), 91-136.

Krebs, Gerhard. "Aussichtslose Sondierung: Japanische Friedensfühler und schwedische Vermittlungsversuche 1944/45." Viertelsjabrhefte für Zeitgeschichte 45 , no. 3 (July 1997), 425-448.

Leifland, Leif. General Böhmes val: Sverige och det nazistiska Tyskland våren 1945 [General Böhme's choice: Sweden and Nazi Germany, Spring 1945]. Stockholm: Norstedt, 1992.

McKay, C.G. From Information to Intrigue: Studies in Secret Service based on the Swedish Experience, 1939-1945. London: Frank Cass, 1993.

Miyasugi Hiroyasu. "Dainijitaisenki chūritsukoku Supein-Porutogaru de no Nihon no jōhōkatsudō to gaikō-gunji e no eikyō" [The impact on Japan's intelligence activities and diplomacy and military affairs in the neutral Spain and Portugal during the Second World War]. Takushoku daigaku kokusai Nihon bunka kenkyū l (2018), 1-57.

Nihon gaikō bunsho dejitaru korekushon, Taiheiyō sensō [Digital collection of Japanese diplomatic documents: The Pacific War], vol. 3, edited by Gaimushō, https:// www.mofa.go.jp/ mofaj/annai/honsho/shiryo/archives/pdfs/taiheiyo3_03.p df. Accessed April 11, 2019.

Nihon gaikō hyakunen shōshi [A short history of the past century of Japanese diplomacy], edited by Gaimushō, rev. ed. Tokyo: Yamada shoin, 1958.

Nihon gaiköshi jiten [The encyclopedia of Japanese diplomatic history], edited by Gaimushō gaikō shiryōkan Nihon gaikōshi jiten hensan iinkai. 2nd ed. Tokyo: Yamakawa shuppansha, 1992.

Ōhata Tokushirō. Nihon gaikōshi [A Japanese diplomatic history]. Tokyo: Azuma shuppan, 1978.

Shigemitsu, Mamoru. Japan and Her Destiny: My Struggle for Peace. London: Hutchinson, 1958.

Shögen: Watashi no shōwashi [Testimony: My Shōwa history], edited by Tōkyō 12 channeru hōdōbu, vol. 5. Tokyo: Gakugei shorin, 1969.

Shöwashi no tennō [The emperor in the history of the Shōwa period], vol. 2, edited by Yomiuri Shimbunsha. Tokyo: Yomiuri Shimbunsha, 1967.

Shüsen shiroku [Historical record of the termination of the war], edited by Gaimushō, vol. 2. Tokyo: Hokuyōsha, 1977.

"Svenskarna i Tokyo välbehållna" [The Swedes in Tokyo well]. Dagens Nyheter, May 27,1945 . 
Sveriges statskalender för året 1945 [Sweden's official gazette 1945]. Stockholm and Uppsala, 1945.

U.S. Department of State. Foreign Relations of the United States, 1945, Diplomatic Papers, vol. 6: The British Commonwealth, The Far East. Washington, DC: U.S. Government Printing Office, 1969.

Woodward, Sir Llewellyn. British Foreign Policy in the Second World War, vol. 5. London: Her Majesty's Stationery Office, 1976.

Zetterberg, Kent. "Svensk säkerhetspolitik i krigsslutet och inför det nya Europa 1945" [Swedish security policy at the end of the war and encountering the new Europe 1945]. In Horisonten klarnar: 1945 - krigsslut [The horizon dawns the end of the war], edited by Bo Huldt and Klaus-Richard Böhme, 175-202. Stockholm: Svenskt Militärhistoriskt Bibliotek, 2002.

\section{Personal communications}

Bagge, Lillebil, January 31, 1994

Björk, Kaj, Ambassador, October 13, 1999

Fredriksson, Berndt, Head, The archive of the Foreign Ministry, August 30, 1995

Jarring, Gunnar, Ambassador, September 5, 1994

Sydow, Erik von, Ambassador, July 11, 1993, January 29, 1994, April 21, 1996 


\section{Conclusion}

\section{After war}

As the war in Europe approached its inevitable end, Finland sued for peace with Moscow; Denmark and Norway were liberated; and on May 2, 1945, two days after Hitler had committed suicide, Berlin fell to Soviet troops. Although not all occupied nations were liberated (the unfortunate Baltic States would not regain independence for half a century), on May 7, Stockholm witnessed boisterous peace celebrations, observed by dismayed Japanese diplomats. As we know, relations between Stockholm and Tokyo remained normal, which contrasted with Finland and Denmark that broke off diplomatic contact, and Norway that even declared war. ${ }^{1}$ On July 31, 1945, Sweden's national coalition government was dissolved and replaced by a Social Democratic cabinet, with Östen Undén as the new foreign minister. The war in Europe was over and the road to postwar prosperity lay open. ${ }^{2}$

The situation could not have been more different for Japan. On August 15, the Emperor's voice was aired in a radio broadcast for the first time. Announcing the unconditional surrender of the nation, he ordered all forces to lay down their weapons. Two weeks later, on September 2, Foreign Minister Shigemitsu Mamoru signed the instrument of surrender on the USS Missouri. The Long Second World War that had begun at a railway track in Manchuria ended on board a battleship in the Pacific. Japan accepted defeat. With that started seven years of US occupation, a transitional leadership in Tokyo, war crime trials, and the restructuring of the former Empire. Korea became an independent state again but soon broke up into two separate countries, later suffering from another devastating war-the first one of the emerging Cold War. Manchukuo was reintegrated into China, while Taiwan was liberated and later became the home of Chiang Kai-shek's Republic of China after he lost the mainland to the Communists, who proclaimed the People's Republic of China from the old capital Peking, in 1949. Large parts of the Empire's diaspora-Japanese soldiers and civilians-returned to Japan, sometimes after years of imprisonment. They came home to a destroyed country, where major cities lay in ashes. Hiroshima and Nagasaki being only the most infamous examples because of their obliteration by the first atomic bombs. Many other cities had suffered similar destruction by conventional weapons. 


\section{Conclusion}

The firebombing raid of Tokyo on the night of March 9-10 alone killed more than 100,000 people-roughly similar to the death that the A-bombs wreaked. Minister Bagge did not have to witness the devastation anymore, but his Swiss colleague, Camille Gorgé, described the capital in September 1945 as "a moonlike city, disfigured. Ruins, kilometers on end. I do not know any more where I am. I do not recognize a single district. I am somewhere else, on a different planet." 3

The Gaimushō, too, lay in ashes, as did its diplomacy. With the loss of sovereignty, all decision-making power on Japan's external affairs passed to the United States occupying forces under General Douglas MacArthur and the US government. The Americans swiftly forbade an independent Japanese diplomacy, ordering its embassies, legations, and consulates abroad to be handed over to US representatives. It was the end of official diplomatic contact between third states and Japan. Only for administrative purposes were foreign representatives allowed to interact with the beaten-down Gaimushō in its temporary premises, but not for political contact with the provisional Japanese cabinet. Until mid-November 1945 when Japan broke the diplomatic relation with Sweden, Erik von Sydow served as charge d'affaires. Later, Olof Ripa took on the role as Diplomatic Representative to the Supreme Commander of the Allied Powers. Sweden could no longer appoint a new plenipotentiary to Tokyo nor receive new Japanese representatives in Stockholm. It is an irony of history that Swedish-Japanese diplomacy survived 15 years of war but not the reestablishment of peace.

To be fair, Shigemitsu's signature on the Missouri did not technically restore peace, it just ended hostilities. A peace agreement was not signed until 1951, in San Francisco. Only then Japan regained its sovereignty, after which SwedishJapanese diplomatic relations were promptly reestablished. In the meantime, Sweden's other primary interest - trade-started to recover from the disruptions of the war. Surprisingly fast, commerce became possible again. Although the official statistics in Sweden are empty for the year 1946, trade figures reappear

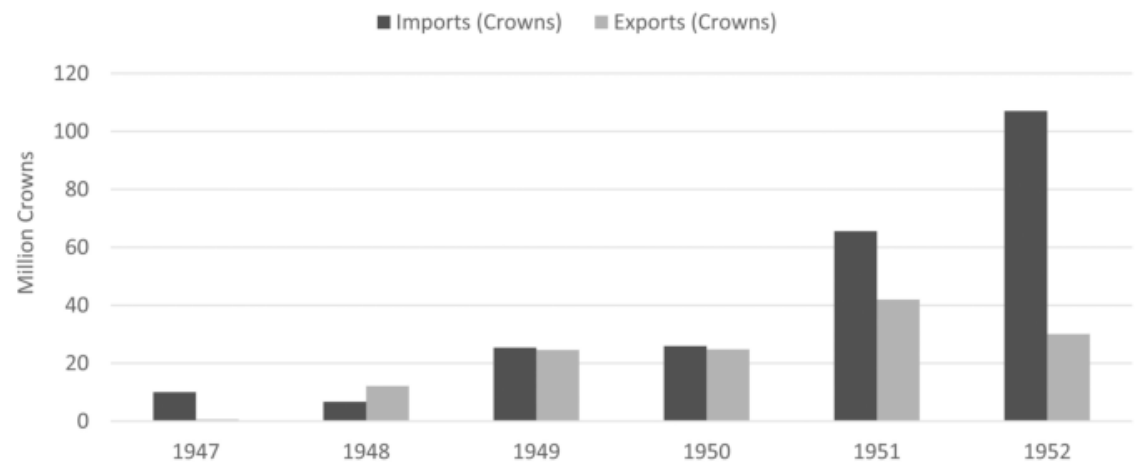

Figure 8.1 Value of imports from and exports to Japan 1947-1952. Source: Statistisk årsbok för Sverige, 1950, 142-143; 1953, 132-133. 
already for 1947 again. They show that although exports were only worth a meager SEK 0.5 million, imports were valued already at over SEK 9 million. That is nearly the level at which imports stood right before Pearl Harbor. The following years of US occupation would see further growth in both directions. By the time Japan became independent again, trade was worth many times what it was before the Pacific War (see Figure 8.1). Hence, although the occupation ended the official diplomatic contact between Sweden and Japan, it did not terminate their trade relationship. On the contrary, the end of belligerency was conducive to the return to business as usual.

\section{Final remarks}

The purpose of this book was to study Sweden's interactions with Japan during a volatile and violent moment of its history, with the goal of shedding light also on the wider international context of the Long Second World War. So, what did we learn? For one, we can now answer the question why SwedishJapanese relations remained intact during the warfare in China and the War in the Pacific. The trivial but honest answer is that it simply always made sense for Sweden and Japan to continue normal relations. The Swedish experience was, as social scientists call it, path dependent. In the same way that Sweden continued its relationship with the United States and Great Britain, there was no reason for Stockholm to give up its relationship with Japan. After 1905, Japan was a pivotal state for Sweden's Far Eastern trade strategy. Although commerce with Japan and China was far less extensive than trade with Western Great Powers or Scandinavian countries, individual firms and the business community in general wanted to maintain access to this region, which they saw as an important market with much potential. Although Japan's actions in the League of Nations went strongly against Sweden's strategic interests for a law-based international society, Japanese provocations were never directly targeted against Stockholm. There was no Swedish "Pearl Harbor moment," not even a "Manila moment," as for Spain. Japan was never responsible for the death of many Swedes or infringements on other vital interests. Bilaterally, Stockholm was unhappy with Tokyo's actions but never ostracized to a point that would have called for a rupture of relations. In addition, once the war turned against Japan, Sweden had become so deeply engaged in diplomatic activities for Tokyo and the Allies that cutting ties with Japan would have been to the detriment of both sides. From a humanitarian perspective, Sweden was useful as a neutral that could act diplomatically between the fronts. It did so in the name of all parties. Be it well understood, however, that these actions were not taken out of pure generosity. As Envoy Bagge so clearly formulated, Sweden's Good Office services were part of its engagement strategy that was supposed to enable its own (trade) interests. It was a tactic that did not always produce direct results-especially during the last years of the Pacific War-but considering how quickly trade rebounded after the end of hostilities, one is tempted to conclude that it was not completely without merit. 
The previous chapters also show that Sweden's return to its traditional neutrality in the late 1930s was influenced not only by the Abyssinian sanctions fiasco, and the threat from a rearming Germany, but also by Japan's aggressive challenge in East Asia. Sweden was among the most outspoken voices in Geneva against these aggressions, but without collective action in the form of sanctions or an intervention, there was no way of reining in Japan's militarists. Tokyo even withdrew from the League of Nations, but no consequences followed. This is not to argue that Sweden was on higher moral ground. Stockholm, too, did not try to impose punishment from its side. Unilateral action would, theoretically, have been an option but even a grassroots consumer boycott, after the bombing of Chinese cities, failed to gather enough support. There were prominent voices not only in the business community but also among diplomats and publicists, who subscribed to Japan's version of the "Manchurian question" which held that Japan was only policing a lawless region. In short, there was no common interpretation of Manchuria or the "Chinese incident," neither domestically nor internationally, and that paralyzed attempts at collective security through the League. Only once this failure became painfully evident (increased by the Abyssinian crisis) Stockholm returned to the principles of neutrality since that was the last available security paradigm in the absence of multilateral forums.

Once that decision was taken, it was clear that there would be no more question about opposing Japan politically or commercially. In addition, during World War I, Sweden's foreign trade policy had been strictly impartial, which the government at the time had viewed as a pillar of an equidistant neutrality. But trade based on "fairness" toward both belligerent parties instead of the needs of the Swedish population had caused serious food shortage which translated into widespread social unrest. In 1939, it was clear that neutrality would have to be more flexible, less concerned about symmetric trade, and more about national priorities. Just like other states, the neutrals, too, had a right to put their own interests first. It was nobody less than the ardent internationalist Östen Undén who formulated that policy in $1938 .{ }^{4}$ Over the course of the European war, Sweden consequently traded asymmetrically with the Allied and Axis Powers. Which belligerent received what kind of economic benefits depended mostly on the development of the war and the relative threat level. ${ }^{5}$ In light of this European strategy, and the fact that Sweden had already strictly separated commerce and politics when dealing with Japan, it comes as no surprise that the "business as usual" approach continued all along, until 1945 (and beyond). Although to do so, Sweden needed to leverage its full weight in the form of Envoy Bagge actively taking over the trade interests of the companies in the Empire-even to the point where the directors of the trading companies would complain about his interferences in setting prices and negotiating terms with customers. Then again, that was but a natural reaction to the nationalization of the Japanese industry under government ministries. As private enterprise in Japan was integrated into the state (although the zaibatsu never were purely private), Swedish trade had to parallel the development if it wanted to maintain eye-level in negotiations. It is important to note, however, that the integration of diplomacy and commerce was a two-way 
street. When the Pacific War led to a massive increase in the diplomatic work and costs for Bagge and the legation, because of the Protecting Power mandates and the new humanitarian work, it was only the availability of Swedish personnel and capital in Japan and around the world that allowed him and the Swedish state to cope with the situation. The ability to hire Swedish staff from the companies into his services and use their funds was necessary for the functioning of Bagge's legation. The time when foreign nationals could act as agents of Swedish diplomacy in the form of honorary consuls was over. Between 1941 and 1945, only a Swedish passport had any chance of opening doors to internment camps or persuading the Kenpeitai to let their holders fulfill their Protecting Power duties. In short, the private-public partnership of the Swedish network abroad was essential to neutral trade and diplomacy alike.

It is also worth noting that Sweden was busy diplomatically during the entire 15 years. First, Stockholm was deeply involved in the processes in Geneva, during the period when it implemented a multilateral foreign relations strategy through the League of Nations. Later it was engaged mostly bilaterally with Japan and other belligerents when warfare made its position as a diplomatic service provider valuable. That engagement even came during a time when Japan had lost all political relevance to Sweden and when Swedish politicians and the general public were occupied with the European situation. Neutrality did not mean passivity. The UD never disengaged. On the contrary, it made additional resources available to cope with the increased workload that its active diplomacy needed. On the other hand, it must also be pointed out that semantics mattered surprisingly greatly. That Mukden and the Marco Polo Bridge were both known as "incidents" (just like Nomonhan), and that Japan's belligerency in China was framed in a similar low-key manner, impacted the way in which Sweden could deal with these situations. That becomes clear in comparison to the official "war" that Japan started with the United States and the Allies. Tokyo even transmitted an official declaration of war through its embassy in Washington-albeit only after the attack on Pearl Harbor. Although none of these instances led to a termination of Swedish-Japanese relations, their impacts on the bilateral relationship were distinctly different, as we have seen.

Lastly, although this was clearly a story of change - the waves of violence of Japanese militarists in 1931, 1937, and 1941, all led to visible changes in the way that Sweden interacted with Japan-in the end, it was also an uninterrupted experience. From the Swedish perspective, the Long Second World War was akin to the Cold War-a conflict that raged around it and was dangerous but never actually turned "hot" for Stockholm. Although the Long Second World War impacted the international sphere heavily, and with that the way in which a neutral country could engage with its international partners, those wars of others never created an all-or-nothing situation for Sweden. Certainly, the warfare of the 1940s could also have engulfed its shores-it was a highly contingent moment. But the fact that it did not, opened possibilities for Sweden to act internationally in a way that was different from the possibilities of belligerents but consistent with its interests and historical developments. In this sense, the present narrative 
shows how neutrality for Sweden was not only a security paradigm at home but also an effective instrument of its foreign policy - even as far away as in Japan.

\section{Notes}

1 Onodera, An den Gestaden der Ostsee, 218-219; Yoshitake, Nihonjin wa Hokuō kara nani wo mananda ka, 34.

2 Hadenius, Modern svensk politisk historia, 80-81.

3 DDS, Debâcle au Soleil-levant, 404.

4 Undén to UD, undated reply to memorandum of August 10, 1938, UD to Undén (UDA, 2210.03.1, H 40, Ct). See also Martin Fritz, "Sveriges ekonomiska relationer med Nazityskland" [Sweden's economic relations with Nazi Germany], in Sverige och Nazityskland: Skuldfrågor och moraldebatt [Sweden and Nazi Germany: Questions of guilt and the moral debate], ed. Lars M. Andersson and Mattias Tydén (Stockholm: Dialogos, 2007), 257-258.

5 On the economic aspects of Swedish World War II neutrality with European belligerents, see Eric B. Golson, "The Economics of Neutrality: Spain, Sweden, and Switzerland in the Second World War" (PhD diss., The London School of Economics and Political Science, 2011). Especially chapters 2 and 5. 


\section{Bibliography}

\section{Archive materials}

East Asian authorities

GMS - Gaimushō Archive, Tokyo

(Ministry of Foreign Affairs of Japan/Early Shōwa Period 1926-1945)

A.1.1.0.21-12-1 League of Nations Negotiations

A.1.1.0.21-12-1-4 Records of conversations with Matsuoka Yōsuke

A.1.1.0.21-12-1-5 Negotiations concerning the Sino-Japanese incident, including with the United States

A.1.1.0.30 Documents concerning the China incident, in general

A.1.1.0.30-23 China's appeal to the League of Nations

A.1.1.0.30-32 The Nine Power Conference

A.1.1.0.30-51 Collected proclamations due to the China incident

A.1.1.0.30-6-1 Measures to stop the material help to Chiang Kai-shek via Burma and Hong Kong

E.4.5.0.13 Foreign matchmaking industry and mixed trade matters

L.1.3.0.1-9 Prince Takamatsu's visit to Scandinavia in 1930

M.2.1.013-6 Miscellaneous Documents Relating to the Appointment and Dismissal of Ambassadors or Ministers Stationed in Foreign Countries, U.S. version

JACAR - Japan Center for Asian Historical Records, National Archives of Japan

B04013434900 103. Precedent of declaration of neutrality as executed by Japan

B04013453600 18. Legal opinion about neutrality

B14090870300 7. Okamoto Suemasa

B02032937000 5. Protection of interests of Swedes concerning enemy country trading companies in China (including "American Far Eastern Match Co." in Shanghai) / From December 31, 1941 to February 9, 1942 
B02032937100

B02030738100
5. Protection of interests of Swedes concerning enemy country trading companies in China (including “American Far Eastern Match Co." in Shanghai) / From March 30, 1942 to June 30, 1942

3. Materials on diplomacy: Record of Japan-US negotiations-Materials on Japan-US negotiations (1): The 2nd Konoe Cabinet 2

\section{Swedish authorities}

1919 års tull-och traktatkommittés arkiv, Riksarkivet, Stockholm (Archives of the Tariff and Treaty Committee of 1919, at the Swedish National Archives)

Vol. 120

Archives of the Allmänna säkerhetstjünsten

(Swedish Public Security Service), at the Swedish National Archives

F 2 BB:2 Handels- och propagandarapporter 1941-1942

(Reports on trade and propaganda 1941-1942)

F 2 BB:3 Handels- och propagandarapporter 1943-1945

(Reports on trade and propaganda 1943-1945)

Archives of the NF-byrain

(League of Nations Bureau, Swedish Foreign Ministry), at the Swedish National Archives

B $1: 1$

BA - Beskickningsarkiv, Riksarkivet, Stockholm

(Missions Archive, at the Swedish National Archives)

Beskickningsarkiv Tokyo: 230033.2

E 1 II Inkommande chiffertelegram, 1943-1945 (Incoming Cipher Telegrams)

E 2 I Avgående chiffertelegram, 1933-1942

(Outgoing Cipher Telegrams)

E 2 II Avgående chiffertelegram, 1943-1944

(Outgoing Cipher Telegrams)

E 2 III Avgående chiffertelegram, 1945-1948

(Outgoing Cipher Telegrams)

E 4 III Korrespondens, 1937-1943

(Correspondence)

E 4 IV Korrespondens, 1944-1948

(Correspondence)

F 2b I Administrativa handlingar, 1941-1946

(Administrative documents) 
F 2c I Handlingar rörande Y.M.C.A., 1942-1944

(Documents Concerning Y.M.C.A.)

F 2e III Passansökningar och krigsfångeärenden, 1943

(Passport Applications and Prisoner of War Cases)

Försvarsstabens Arkiv, Krigsarkivet, Riksarkivet, Stockholm

(Archive of the Defense Staff, War Archives, at the Swedish National Archives)

Serie Ö I:10 Militära översikter, utredningar och sammanställningar. Japan 1936-1952

(Military surveys, investigations and summarized reports)

Svenska Handelsdepartementets Arkiv, Huvudarkivet, Riksarkivet, Stockholm (Archive of the Swedish Ministry of Trade, main archive of the Swedish National Archives),

F II aa: 203 Rapporter från UD. Utomeuropa, 1938 (Reports from the Ministry of Foreign Affairs. Overseas)

UDA - Utrikesdepartementets Arkiv, Riksarkivet, Stockholm

(Archive of the Swedish Ministry of Foreign Affairs at the Swedish National Archives)

1902 års dossiersystem: 2210.02

(1902 Dossier System)

$1 \mathrm{~K} \quad$ Rapporter från beskickningarna i Tokyo och Beijing, 19011919 (Reports from the Tokyo and Beijing legations)

21 U 1 Rapporter från beskickningarna, 1914-1931 (Reports from legations)

103 A $8 \quad$ Uppsägning av svensk-japanska handelstraktaten av 1896 samt underhandlingar om ny traktat (Termination of the SwedishJapanese Trade Treaty of 1896 and negotiations on a new treaty)

1920 års dossiersystem 1918-1952: 2210.03.1

(1920 Dossier System)

H $6 \mathrm{Xj} \quad$ Allmänt angående handel och industri, Japan (General regarding trade and industry, Japan)

H 6 Xm Allmänt angående handel, industri och hantverk, Manchukuo, 1934- (General concerning trade, industry and handicrafts, Manchukuo)

H $40 \mathrm{Ct} \quad$ Järn och stål, Tyskland (Iron and steel, Germany)

$\mathrm{H} 100 \mathrm{Xj} \quad$ Export- och import- samt transiteringsförbud, Japan, 19211952 (Export and import and transit ban, Japan) 
HP I N Handlingar från utrikesnämnden (Documents from the Advisory Council of Foreign Affairs)

HP I S Utrikesministerns samtal med utländska beskickningschefer (Foreign Minister's talks with heads of foreign missions)

HP I Xj Politik: allmänt, Japan (Politics: Japan in general)

Vol. XIII: $\quad$ 1937-1938

Vol. XIV: $\quad$ 1938-1939

Vol. XV: 1939-1941

Vol. XVI: $\quad$ 1941-1942

Vol. XVII: $\quad$ 1942-1944

Vol. XVIII: 1944-1946

HP I Xk Politik: allmänt, Kina

(Politics: China in general)

HP $12 \mathrm{Xm}$ Statsformer och konstitutioner samt frågor om erkännande av nya stater (Forms of government and constitutions as well as issues of recognition of new states)

HP $20 \mathrm{G} \quad$ Konflikter i Fjärran Östern (Conflicts in the Far East)

HP $22 \mathrm{Ab}$ Politik: allmänt, 1939-1940 (Politics: General)

HP 35 A Italiensk-abessinska konflikten, 1934- (Italian-Abyssinian conflict)

HP 37 A Japansk-kinesiska kriget 1937-. Allmänt (Japan-China War 1937- . General)

HP 37 B Japansk-kinesiska kriget 1937-. Medlingsförsök. Brysselkonferensen m.m. (Japan-China War 1937-. Mediation attempts. The Brussels Conference, etc.)

HP 37 D Humanitär hjälpverksamhet i Kina (Humanitarian aid operations in China)

HP $64 \mathrm{Xj}$ Handel och sjöfart i övrigt: diplomatiska framställningar, underhandlingar och avtal. Japan (Trade and shipping in general: diplomatic petitions, negotiations and agreements with Japan)

HP 64 Xk Handel och sjöfart i övrigt: diplomatiska framställningar, underhandlingar och avtal. Kina (Trade and shipping in general: diplomatic petitions, negotiations and agreements with China)

HP $64 \mathrm{Xk}^{1}$ Traktatfrågor: vapenexporten till Kina (Treaty issues: arms exports to China)

HP 64 Xm Handel och sjöfart i övrigt: diplomatiska framställningar, underhandlingar och avtal. Manchukuo 1935- (Trade and shipping in general: diplomatic petitions, negotiations and agreements. Manchukuo)

P 19 A Skyddsmaktsuppdrag: Allmänt (Protecting Power mandates: General)

P $83 \mathrm{Xk} \quad$ Missioner, Kina (Mission, China) 
Utrikesdepartementet Andra B-avdelningen, 1939-1969: 2212.02

(Ministry for Foreign Affairs Second B Section)

F l Grupp 1 Xj Inkommande chiffertelegram, 1943-1945 (Incoming Cipher Telegrams)

\section{Swedish nongovernmental sources}

Arvid Lindmans Samling, Riksarkivet, Stockholm (Arvid Lindman's Collection, at the Swedish National Archives)

Vol. 18 Utrikesnämnden, 1931-1935 (The Advisory Council of Foreign Affairs)

Gadelius' arkiv, Centralarkivet, $\mathrm{ABB}$, Västerås

(Gadelius's Archive, ABB, Västerås, Sweden)

Vol. 191.02.003 Knut Gadelius, brev 1930-1932 (Knut Gadelius, Letters)

Vol. 191.02.025 Familjen Gadelius, intervjuer och ihågkomster (The Gadelius family, interviews and reminiscences)

Brauns, Eric. Gadelius \& Co - 50 år i Japan 1907-1957, otryckt företagshistorik (Gadelius \& Co. - 50 Years in Japan, 1907-1957, unpublished corporate history)

LO:s arkiv, Arbetarrörelsens Arkiv, Stockholm

(Archives of the National Federation of Labor, Archives of the Workers' Movement)

Landssekretariatets protokoll 1937-39

(Minutes of the National Secretariat)

Ostasiatiska Kompaniets Arkiv, Gothenburg (Archives of the East Asian Company)

Förvaltningsberättelse, balansräkning och revisionsberättelse över 1937 års verksamhet (Administrative report, balance sheet account, and audit report for 1937)

Förvaltningsberättelse, balansräkning och revisionsberättelse över 1938 års verksamhet (Administrative report, balance sheet account, and audit report for 1938)

Styrelseprotokoll (Board Meeting Minutes), 1934-1938

Sven Hedins samling, 720827, Riksarkivet, Stockholm

(Sven Hedin's Collection) Vol. 328

Diaries 1937-1939

Svenska kommittén av världssamling för fred, arkiv, Riksarkivet, Stockholm (Archive of the Swedish Committee of the International Peace Campaign, at the Swedish National Archives)

A 1: 1 Mötes- och AU-protokoll, 1936-1939 (Minutes from meetings and the executive committee) 


\section{International sources}

DDS - Diplomatic Documents of Switzerland

dodis.ch/50633 Debâcle au Soleil-levant - Journal de Camille Gorgé

Federal Archives of Switzerland

E2001D\#1000/15531980* Vertretung amerikanischer Interessen in Japan und von ihm besetzten Gebieten, Burma, Hongkong, Philippinen, Singapore, Mandschukuo, Shanghai, 1941-1945 (Representation of American interests in Japan and occupied territories: Burma, Hongkong, Philippines, Singapore, Manchukuo, Shanghai, 1941-1945)

ICRCAA - International Committee of the Red Cross Audiovisual Archive, Switzerland

V-P-HIST-00985-22 International Committee of the Red Cross, War 19391945. Barcelona. German-allied exchange. Departure of the hospital ship "Gradisca" which passes near the Swedish boat "Gripsholm" having in its board British and American prisoners

League of Nations Archive, Geneva

League of Nations Official Journal

Records of the Special Session of the Assembly: Convened in virtue of Article 15 of the Covenant at the Request of the Chinese Government.

1932 Volume I: $\quad$ Special Supplement No. 101

1932 Volume II: $\quad$ Special Supplement No. 102

1933 Volume III: $\quad$ Special Supplement No. 111

Documents Relating to the Question of the Application of the Principles of the Covenant

1936 Special Supplement No. 154

LHMA - Liddell Hart Military Archives, King's College, London

MAGIC Summary No. 272, December 23, 1942.

332 , February 21, 1943.

378, April 8, 1943.

382, April 12, 1943.

384, April 14, 1943.

516, August 24, 1943.

988, December 8, 1944. 


\section{Official publications}

\section{Official Swedish publications}

Aktstycken utgivna av Kungl Utrikesdepartementet, Nationernas Förbunds första (etc.) församling i Genève, Stockholm 1921-40 (Documents issued by the Royal UD, first (etc.) meeting of the League of Nations in Geneva, Stockholm 1921-40)

Årgång (Year) 1931

1932

1938

Export Committee, Betänkande med utredning och förslag angående åtgärder till den svenska exportnäringens främjande, avgivet av 1938 års exportutredning [Report with survey and proposal concerning measures for the promotion of Swedish exports, presented by the Export Committee of 1938], Stockholm: Norstedt, 1938.

Statistiska Centralbyrain (Central Office for Statistics), Stockholm

Levnadskostnadsindex/KPI (juli 1914=100), Historiska tal 1830- (Cost of living index since 1830). Online at https://www.scb.se/hitta-statistik/statistik-efter -amne/priser-och-konsumtion/konsumentprisindex/konsumentprisindex-kpi/ pong/tabell-och-diagram/konsumentprisindex-kpi/kpi-historiska-tal-1830.

Statistisk årsbok för Sverige (Statistical Yearbook for Sweden)

Årgång (Year) 1914

1923

1929

1938

1939

1946

1950

1953

Handel, Berättelser från Kommerskollegium (Trade, Reports from the National Board of Trade)

Årgång (Year) 1919-1938

Redogörelser avgivna till Utrikesnämnden i enlighet med $\$ 54$ RF, Stockholm 1928-1942 (Reports submitted to the Advisory Council of Foreign Affairs in accordance with $\$ 54$ of the Instrument of Government)

$\begin{array}{ll}\text { Report } & 1930 \\ \text { Report } & 1932 \\ \text { Report } & 1935 \\ \text { Report } & 1938 \\ \text { Report } & 1939\end{array}$


RP - Riksdagens Protokoll (Parliamentary Records of the Swedish Riksdag)

Första kammaren (FK) (First Chamber)

$$
\begin{aligned}
& \text { 1933, No. } 14 \\
& \text { 1936, No. } 3,36 \\
& \text { 1938, No. } 1,24,40 \\
& \text { 1939, No. } 39 \\
& \text { 1942, No. } 3 \\
& \text { 1943, No. } 30
\end{aligned}
$$

Andra kammaren (AK) (Second Chamber)

$$
\begin{aligned}
& \text { 1933, No. } 5 \\
& \text { 1936, No. } 4 \\
& \text { 1938, No. } 4 \\
& \text { 1939, No. } 4 \\
& \text { 1942, No. } 3
\end{aligned}
$$

Utrikesdepartementet (Swedish Ministry of Foreign Affairs)

Kungl. utrikesdepartementets kalender [Calendar of the Royal Foreign Ministry]. Stockholm: Almqvist \& Wiksell.

Årgång (Year) 1938

1955

\section{Official international publications}

Documents on British Foreign Policy, 1919-1939, Second Series, Vol. XII. London 1972.

Eidgenössisches Statistisches Amt. Statistisches Jahrbuch der Schweiz 1943 [Statistical Yearbook of Switzerland 1943]. Basel: E. Birkhäuser \& Cie, 1944.

Gaimushō Jōyakukyoku (ed.), Kyū Jòyaku isan [Former Treaties]. Tokyo, 1934.

Gaimushō Tsūshōkyoku (ed.), Kaigai Keizai Jijōo [Overseas Economic Conditions]. Tokyo, 1939.

"Resolution for the Dissolution of the League of Nations, Adopted by the Assembly on April 18, 1946." International Organization 1, no. 1 (1947): 146-251.

United States. The Conference of Brussels: November 3-24, 1937. Convened in Virtue of Article 7 of the Nine-Power Treaty of Washington of 1922. Washington, DC: Government Printing Office, 1938.

- Peace and War: United States Foreign Policy 1931-1941. Washington, DC: Government Printing Office, 1943.

\section{Magazines and journals}

Hvar 8 Dag [Every Eight Days]. Stockholm

Idun. Stockholm

Mellanfolkligt samarbete [International Cooperation]

Sfüren. Tidning för SKF-folk [The Sphere. Journal for SKF Employees]

Shükan Jihō [Weekly Announcements] 
Svensk Export [Swedish Exports]

Svensk Tidskrift [The Swedish Journal]

Svensk-Japanska Sällskapets arsskrift [Yearbook of the Swedish-Japanese Association]

Sveriges Försvar [Sweden's Defense]

The International Gleanings from Japan

Tiden [Times]

\section{Newspapers}

Aftonbladet, 1830-now.

Arbetaren, 1922-now.

Chügai Shōgyō Shinpō, 1889-1942.

Dagens Tidning, 1911-1914.

Den Svenske Nationalsocialisten, 1933-1950.

Göteborgs Handels- och Sjöfartstidning, 1823-1973.

Japan Advertiser, 1913-1940.

Japan Times \& Mail, 1918-1940.

Neue Zürcher Zeitung, 1780-now (until 1821 Zürcher Zeitung).

Norrskensflamman, 1906-now (called Flamman since 1998).

Nya Dagligt Allehanda, 1859-1944.

Östergötlands Dagblad, 1890-1959.

Social-Demokraten, 1885-1944 (called Morgon-Tidningen 1944-1958).

Stockholms-Tidningen, 1889-1984 (interruption 1966-1981).

Svenska Dagbladet, 1884-now.

Svenska Morgonbladet, 1890-1958.

The Japan Times, 1897-now.

The New York Times, 1851-now.

Tökyō Asahi Shimbun, 1879-now.

Tōkyō Nichi Nichi Shimbun, 1872-1943.

Tōyō Keizai Shinpōsha, 1895-now.

Yomiuri Shimbun, 1874-now.

\section{Databases}

Meiji Portraits (by Bernd Lepach), www.meiji-portraits.de.

Statistics Sweden, www.scb.se.

The Wrecksite, wrecksite.eu.

Svenska Dagstidningar [Swedish Newspapers], Royal Library of Sweden. 


\section{Literature}

Agrell, Wilhelm. Fred och fruktan. Sveriges säkerhetspolitiska historia 1918-2000 [Peace and fear. The history of Swedish security policy, 1918-2000]. Lund: Historiska Media, 2000.

- Stockholm som spioncentral: spåren efter tre hemliga städer [Stockholm as a spy center: Traces of three secret cities]. Lund: Historiska Media, 2020.

Akiyama, Kaori. Hawai nikkeijin no kyösei shüyōshi: Taiheiyōsensō to yokuryūsho no hensen [The history of Japanese internment in Hawai' $i$ : Changes in the camps and camp life during the Pacific War]. Tokyo: Sairyūsha, 2020.

Ankarcrona, Sten S:son. "A Review of the Commercial Relations between Sweden and Japan." In Svensk-Japanska Sällskapets àrsskrift [Yearbook of the SwedishJapanese Association], edited by Svensk-Japanska Sällskapet, 49-52. Stockholm: Victor Pettersson, 1934.

Arakawa, Ken'ichi. "Japanese Naval Blockade of China in the Second Sino-Japanese War, 1937-1941." In Naval Blockades and Seapower: Strategies and CounterStrategies 1805-2005, edited by Bruce A. Elleman and S.C.M. Paine, 105-166. Oxon: Routledge, 2006.

Arima, Manabu. Teikoku no shōwa [The Empire during the Shōwa era]. Tokyo: Kōdansha, 2010.

Auboin, Roger. "The Bank for International Settlements 1930-1955." In Essays in International Finance, edited by Gardner Patterson, 1-49. Princeton: Princeton University, 1955.

Auslin, Michael R. Negotiating with Imperialism: The Unequal Treaties and the Culture of Japanese Diplomacy. Cambridge: Harvard University Press, 2004.

Bagge, Gösta. Politiska tal àr 1937 [Political speeches in 1937]. Stockholm: Egnellska Boktryckeriet, 1937.

Barnhart, Michael A. Japan Prepares for Total War: The Search for Economic Security, 1919-1941. Ithaca: Cornell University Press, 1987.

Boëthius, Maria-Pia. Heder och samvete: Sverige och andra världskriget [With honor and conscience: Sweden and the Second World War]. Stockholm: Norstedt, 1991.

Boheman, Erik. På vakt: Kabinettssekreterare under andra världskriget [On guard: As the state secretary for foreign affairs during the Second World War]. Stockholm: Norstedt, 1964.

Boldt-Christmas, Gustaf E.F., Lilljequist, Olof and Cederberg, Carl-G., eds. Ostasiat. Utgiven med anledning av AB Svenska Ostasiatiska Kompaniets femtioarsjubileum 1957 [Ostasiat. Published on the occasion of the fiftieth anniversary of the Swedish East Asia Co.]. Gothenburg: Svenska Ostasiatiska Kompaniet, 1957.

Bosworth, Richard James Boon. Explaining Auschwitz and Hiroshima: History Writing and the Second World War 1945-1990. London: Routledge, 1993.

Buck, Pearl S. The Good Earth. New York: John Day, 1931.

Burkman, Thomas W. Japan and the League of Nations: Empire and World Order, 1914-1938. Honolulu: University of Hawai'i Press, 2008.

Carlander, Axel. Dagboksanteckningar frän resan rundt jorden 1891-1892 [Diary notes from the world tour in 1891-1892]. Gothenburg: Göteborgs Handelstidnings Aktiebolags Tryckeri, 1893.

Carlgren, Wilhelm M. Svensk utrikespolitik 1939-1945 [Swedish foreign policy, 19391945]. Stockholm: Allmänna Förlaget, 1973. 
Svensk underrättelsetjänst 1939-1945 [Swedish intelligence service, 19391945]. Stockholm: Liber, 1985.

Cassel, Hjalmar. Det nya Östasien [New East Asia]. Stockholm: Alberts Bonniers Förlag, 1906.

Cederschiöld, Gunnar and Feilitzen, Einar. Den svenska tändsticksindustriens historia före de stora sammanslagningarna [The history of the Swedish match industry before the big mergers]. Stockholm: Natur och Kultur, 1946.

Corbett, Paul Scott. Quiet Passages: The Exchange of Civilians between the United States and Japan during the Second World War. Kent: Kent State University Press, 1987.

Cortazzi, Hugh. "The Death of Melville James Cox (1885-1940) in Tokyo on 29 July 1940: Arrests of British Citizens in Japan in 1940 and 1941." In Britain and Japan: Biographical Portraits, 491-506. Leiden: Global Oriental, 2013.

Craigie, Robert. Behind the Japanese Mask. London: Hutchinson \& Co., 1945.

Davidann, Jon Thares. Cultural Diplomacy in U.S. Japanese Relations, 1919-1941. New York: Palgrave Macmillan, 2007.

Delcorde, Raoul. Belgian Diplomats. Edited by Pierre Mardaga. Wavre: Mardaga, 2010.

Donzé, Pierre-Yves, Hauser, Claude, Lottaz, Pascal and Maître, Andy, eds. Journal d'un témoin: Camille Gorgé, diplomat Suisse dans le Japon en guerre 1940-1945 [Journal of a witness: Camille Gorgé, Swiss diplomat in wartime Japan]. Vol. 10, Quaderni di Dodis, Berne: Diplomatic Documents of Switzerland, 2018.

Dower, John W. War Without Mercy: Race and Power in the Pacific War. New York: Pantheon Books, 1986.

Drea, Edward J. The 1942 Japanese General Election: Political Mobilization in Wartime Japan. Kansas: Center For East Asian Studies at the University of Kansas, 1979.

Edele, Mark. The Soviet Union: A Short History. New Jersey: Wiley Blackwell, 2019.

Edström, Bert. "Widar Bagge, Japan and the End of the Second World War." Center for Pacific Asia Studies at Stockholm University, Working Paper 41, 1995.

-. "Sweden: 23-30 April 1873." In The Iwakura Mission in America and Europe: A New Assessment, edited by Ian Nish. London: RoutledgeCurzon, 2004.

-. "Japan as a Distant Friend: Scandinavian Countries Adjusting to Japan's Emergence as a Great Power." In The Decade of the Great War: Japan and the Wider World, edited by Tze-ki Hon Tosh Minohara and Evan Dawley. Leiden: Brill, 2014.

Edström, Bert and Svanberg, Ingvar, eds. Fjärrannära: kontakter mellan Sverige och Japan genom tidern [Far and near - Contacts between Sweden and Japan through the ages], Stockholm: Arena, 2001.

Fransson, Stig A. Bofors 350 år [Bofors 350 years]. Stockholm: Probus Förlag, 1996.

Fritz, Martin. "Sveriges ekonomiska relationer med Nazityskland" [Sweden's economic relations with Nazi Germany], in Sverige och Nazityskland: Skuldfraggor och moraldebatt [Sweden and Nazi Germany: Questions of guilt and the moral debate], edited by Lars M. Andersson and Mattias Tydén. Stockholm: Dialogos, 2007.

Frykholm, Lars and Brundin, Margareta, eds. Samråd i krigstid: Utrikesutskottets memorialprotokoll 1940-1945 [Wartime consultation: The Foreign Affairs Committee's memorial protocol 1940-1945]. Stockholm: Sveriges Riksdag, 2007.

Fujiwara, Ginjirō, Bōkan sannen [Three years of work and leisure]. Tokyo: Tōyō Keizai Shinpōsha, 1942. 
Gerhard, Ingemar. Problem rörande Sveriges utrikeshandel 1936/8 [Problems related to Swedish foreign trade, 1936/8]. Gothenburg: Elanders Boktryckeri, 1948.

Gilmour, John. Sweden, the Swastika and Stalin: The Swedish Experience in the Second World War. Edinburgh: Edinburgh University Press, 2010.

Goldman, Stuart D. Nomonhan, 1939: The Red Army's Victory that Shaped World War II. Annapolis: Naval Institute Press, 2012.

Golson, Eric Bernard. "The Economics of Neutrality: Spain, Sweden, and Switzerland in the Second World War." PhD diss., London School of Economics and Political Science, 2011.

Gordon, Andrew. A Modern History of Japan: From Tokugawa Times to the Present. Oxford: Oxford University Press, 2003.

Gorgé, Camille. Débâcle au Soleil-levant: Journal d'un témoin [Fiasco in the land of the Rising Sun: The diary of a witness]. Berne: Diplomatic Documents of Switzerland, 1940-1945.

—. "Les Trois Japons" [The three Japans]. In Nippon-Helvetia, edited by Comité du Centenaire. Tokyo: Akatsuki Insatsu, 1964.

Grew, Joseph C. Ten Years in Japan. New York: Simon \& Schuster, 1944.

Hadenius, Stig. Modern svensk politisk historia: Konflikt och samförstånd [Modern Swedish political history: Conflict and consensus]. 6th ed. Stockholm: Hjalmarson \& Högberg, 2003.

Hägglöf, Gunnar M. Svensk krigshandelspolitik under andra världskriget [Swedish trade policy during World War II]. Stockholm: Norstedt, 1958.

—. "A Test of Neutrality: Sweden in the Second World War." International Affairs 36 (1960): 153-167.

- Möte med Europa. Paris-London-Moskva-Genève-Berlin 1926-1940 [Encounter with Europe. Paris-London-Moscow-Geneva-Berlin, 1926-1940]. Stockholm: Norstedt, 1971.

Handō, Kazutoshi. Shōwashi [The history of the Shōwa era]. Part I (1926-1945). Tokyo: Heibonsha, 2005.

Harrison, Mark. The Economics of World War II: Six Great Powers in International Comparison. Cambridge: Cambridge University Press, 2000.

Hedin, Sven. Sverige och den Stora Östern [Sweden and the Far East]. Stockholm: Alberts Bonniers Förlag, 1905.

Hellyer, Robert I. Defining Engagement: Japan and Global Contexts, 1640-1868. Cambridge: Harvard University Asia Center, 2009.

Hildebrand, Bengt. "Ewerlöf, släkt" [The family Ewerlöf]. In Svenskt biografiskt lexikon [Dictionary of Swedish national biography]. Stockholm: Riksarkivet, 1953; online ed., 2020. https://sok.riksarkivet.se/sbl/artikel/15574.

Holmberg, Åke. Världen bortom västerlandet: Svensk syn på fjärran länder och folk frä 1700-talet till första världskriget [The world beyond the West: Distant lands and peoples through Swedish eyes from the 18th century to the First World War]. Gothenburg: Kungl. Vetenskaps- och vitterhets-samhället, 1988.

Honma, Ryūshi, ed. Nippon keizai tōkeishū 1868-1945 [Japanese economic statistics, 1868-1945]. Tokyo: Nichigai Associates, 1999.

Howland, Douglas. "Japanese Neutrality in the Nineteenth Century: International Law and Transcultural Process." Transcultural Studies 1, no. 1 (2010): 14-37.

Hunt, Byron Walfred. "The League of Nations and the Italo-Ethiopian Conflict." PhD diss., University of Montana, 1957. 
Jacobson, G., "David Kristian Bergström.” In Svenskt biografiskt lexikon [Dictionary of Swedish national biography]. Stockholm: Riksarkivet, 1922; online ed., 2020. https://sok.riksarkivet.se/sbl/artikel/18677.

Jangfeldt, Bengt and Watson, Harry D. The Hero of Budapest: The Triumph and Tragedy of Raoul Wallenberg. London: Tauris, 2014.

Jensen, R.J., Davidann, J.T. and Sugita, Y. Trans-Pacific Relations: America, Europe, and Asia in the Twentieth Century. Westport: Praeger, 2003.

Johansson, Alf W. and Torbjörn, Norman. "Sweden's Security and World Peace." In Creating Social Democracy. A Century of the Social Democratic Labor Party In Sweden, edited by Klaus Misgeld, Karl Molin and Klas Åmark. Pennsylvania: Pennsylvania State University Press, 1992.

Jones, S. Shepard. The Scandinavian States and the League of Nations. Princeton: Princeton University Press, 1939.

Karlgren, Bernhard. Japans väg och mål [Japan's path and goal]. Stockholm: Utrikespolitiska institutet, 1940.

Karlsson, Ingela. "Staten och rederierna. Den svenska handelsflottan 1937-1947" [War, state, and shipping companies. The Swedish merchant fleet, 1937-1947]. PhD diss., Gothenburg University, 2003.

_. "Sig själv närmast" [Every man for himself]. In En (o)moralisk handel? Sveriges ekonomiska relationer med Nazityskland [(I)moral trade? Sweden's economic relations with Nazi Germany], edited by Charlotte Haider. Stockholm: Forum för levande historia, 2006.

Kawasaki, Seirō. "Kenkyu Nōto: Meiji jidai no Tōkyō ni atta Gaikoku kōkan (4)." [The foreign missions in Tokyo of the Meiji period (4)]. Gaimusho Chösa Geppō, no. 1, 2014.

__. "Kenkyū Nōto: Meiji jidai no Tōkyō ni atta Gaikoku kōkan (5)." [The Foreign missions in Tokyo of the Meiji period (5)]. Gaimusho Chösa Geppō, no. 2, 2014.

Kluyver, Classina Albertina, ed. Documents on the League of Nations. Leiden: International Intermediary Institute, 1920.

Konoe, Fumimaro. Konoe Fumimaro shuki: heiwa e no doryoku [Notes by Konoe Fumimaro: The peace efforts]. Tokyo: Chūōkōron Shinsha, 1947.

Krebs, Gerhard. "Aussichtslose Sondierung. Japanische Friedensfühler und schwedische Vermittlungsversuche 1944/5" [Hopeless probing. Japanese peace feelers and Swedish mediation attempts 1944/45]. Vierteljahrshefte für Zeitgeschichte 45, no. 3 (1997): 425-448.

Larsson, Jan. Diplomati och industriellt genombrott. Svenska exportsträvanden på Kina 1906-1916 [Diplomacy and industrial breakthrough: Swedish export ambitions in China, 1906-1916]. Uppsala: Almqvist \& Wiksell, 1977.

Larsson, Nils R. Sverige som skyddsmakt: historik och praxis [Sweden as a Protecting Power. History and practice]. Stockholm: Norstedt, 1988.

Laver, S. Michael. The Sakoku Edicts and the Politics of Tokugawa Hegemony. New York: Cambria Press, 2011.

Leitz, Christian. Sympathy for the Devil: Neutral Europe and Nazi Germany in World War II. New York: New York University Press, 2011.

Lensen, George Alexander. The Strange Neutrality: Soviet-Japanese Relations during the Second World War, 1941-1945. Tallahassee: Diplomatic Press, 1972.

Lönnroth, Erik. Den svenska utrikespolitikens historia, 1919-1939 [The history of Swedish foreign policy, 1919-1939]. Vol. V, Stockholm: Norstedt, 1959. 
Lottaz, Pascal. "Neutral States and Wartime Japan: The Diplomacy of Sweden, Spain, and Switzerland toward the Empire." PhD diss., National Graduate Institute for Policy Studies, 2018.

- "Neutrality and Wartime Japan." In Notions of Neutralities, edited by Pascal Lottaz and Herbert R. Reginbogin, 113-134. Lanham: Lexington, 2019.

Lottaz, Pascal and Reginbogin, Herbert R. "'Private Neutrality' - The Bank for International Settlements." In Notions of Neutralities, edited by Pascal Lottaz and Herbert R. Reginbogin. Lanham: Lexington, 2019.

Lottaz, Pascal and Rodao, Florentino. "The Vatican, WWII, and Asia: Lessons of Neutral Diplomacy." In Notions of Neutralities, edited by Pascal Lottaz and Herbert R. Reginbogin. Lanham: Lexington, 2019.

Makko, Aryo. European Small States and the Role of Consuls in the Age of Empire. Leiden: Brill, 2020.

Malmborg, Mikael af. Neutrality and State-building in Sweden. New York: Palgrave, 2001.

Matsushima, Shikao. "Mission to Sweden.". In Svensk-Japanska Sällskapets årsskrift [Yearbook of the Swedish-Japanese Association], edited by Svensk-Japanska Sälls. Stockholm: Victor Pettersson, 1940.

Mitter, Rana. China's War With Japan, 1937-1945: The Struggle for Survival. London: Penguin Books Limited, 2013.

Möller, Yngve. Rickard Sandler: folkbildare, utrikesminister [Rickard Sandler: educator, foreign minister]. Stockholm: Norstedt, 1990.

Moreno, Rodolfo. Más allá del Oriente [Beyond the East]. Buenos Aires: Editorial Sudamericana, 1946.

Morgenthau, Hans J. “The Resurrection of Neutrality in Europe." American Political Science Review 33 (1939): 473-486.

Mori, Takemaro. Ajia Taiheiyō sensōo [Asia Pacific war]. Tokyo: Shūeisha, 1993.

Nakamura, Takafusa. Shōwashi [The History of the Shōwa Era]. Vol. I. Tokyo: Tōyō Keizai Shinpōsha, 1992.

Neff, Stephen C. The Rights and Duties of Neutrals: A General History. Manchester: Manchester University Press, 2000.

Newsom, David Dunlop. Diplomacy under a Foreign Flag: When Nations Break Relations. London: Hurst \& Company, 1990.

Ninagawa, Arata. Sino-Japanese War and Nullified Nine Power Treaty. Tokyo, 1937.

Nish, Ian. Japanese Foreign Policy 1869-1942: Kasumigaseki to Miyakezaka. Foreign Policies of Great Powers. London: Routledge, 1977.

- Japan's Struggle with Internationalism. Japan, China and the League of Nations 1931-1933. London: Routledge, 1993.

- Japanese Foreign Policy in the Interwar Period. Westport: Praeger, 2002.

- The Iwakura Mission in America and Europe: A New Assessment. London: RoutledgeCurzon, 2004.

Nittzell, Gunnar O. "Gustaf Oskar Wallenberg - En bortglömd Japanvisionär" [Gustaf Oskar Wallenberg - A forgotten Japan visionary]. Orientaliska Studier 55/56 (1994): 39-69.

Nordyke, Eleanor C. and Matsumoto, Scott Y. "Japanese in Hawaii: A Historical and Demographic Perspective." Hawaiian Journal of History 11 (1977): $162-174$.

Norstedt. ed. Vem är det? [Who is it?]. Stockholm: Kungl. Boktryckeriet, 1939. 
Olsson, Kent. Göteborgs historia [The history of Gothenburg] Vol. 3. Stockholm: Nerenius \& Santérus, 1996.

Onodera, Yuriko. An den Gestaden der Ostsee: Onodera Makoto als japanischer Heeresattaché in Riga und Stockholm: (1936-1938, 1940-1945) [On the shores of the Baltic Sea: Onodera Makoto as Japanese military attaché in Riga and Stockholm: (1936-1938, 1940-1945)]. Translated by Ryōji and Mariele Onodera. Edited by Gerhard Krebs. Tokyo: OAG, 1999.

Ottosson, Ingemar. Krig i fredens intresse eller neutralitet till varje pris?: Sverige, NF och fraigan om kollektiv sükerhet 1935-1936 [War in the interest of peace or neutrality at any cost?: Sweden, League of Nations, and the question of collective security, 1935-1936]. Lund: Studentlitteratur, 1986.

—. "Svensk frihandelsimperialism. Det ojämlika fördraget med Japan 18681896" [Swedish Free-trade Imperialism: The unequal treaty with Japan, 18681896]. Historisk Tidskrift 2 (1997): 199-223.

—. "Att framtvinga ett vänskapsavtal - Sverige och Japans öppnande" [Enforcing a treaty of amity: Sweden and the opening of Japan]. In Fjärrannära: Kontakter mellan Sverige och Japan genom Tiderna [Far and near - Contacts between Sweden and Japan through the ages], edited by Bert Edström and Ingvar Svanberg, 65-79. Stockholm: Dialogos Förlag, 2001.

- Handel under protest: Sverige och Japan på väg mot andra världskriget 19311939 [Trade under protest: Sweden and Japan on the way to the Second World War 1931-1939]. Lund: Sekel, 2010.

- Trade under Protest: Sweden, Japan and the East Asian crisis in the 1930s. Tokyo: Center for International Research on the Japanese Economy, 2012.

- Möten $i$ monsunen. Sverige och Kina genom tiderna [Encounters in the monsoon. Sweden and China through the ages]. Stockholm: Dialogos, 2019.

—. "Fujiwara Ginjirō och Japans möte med Sverige" [Fujiwara Ginjirō and Japan's encounter with Sweden] in Orientaliska studier [Oriental Studies], no. $161(2020)$.

Paine, S.C.M. The Wars for Asia 1911-1949. Cambridge: Cambridge University Press, 2012.

Pauer, Erich. "Deutschland-Japan: Überblick über die wirtschaftlichen Beziehungen, 1900-1945 [Germany-Japan: Overview of economic relations, 1900-1945]. In Japan und Deutschland im 20. Jahrhundert [Japan and Germany in the 20th century], edited by Klaus Kracht, Bruno Lewin and Klaus Müller. Wiesbaden: Harrassowitz, 1984.

Peifer, Douglas Carl. Choosing War: Presidential Decisions in the Maine, Lusitania, and Panay incidents. New York: Oxford University Press, 2016.

Politis, Nikolas. Neutrality and Peace. Translated by Francis C. Macken. Washington, DC: Carnegie Endowment for International Peace, 1935.

Ramel, Fredrik. "Från årets förbundsförsamling i Genève” [From this year's General Assembly in Geneva]. In Meddelanden rörande Nationernas förbund [Bulletins concerning the League of Nations]. Stockhom: Svenska föreningen för Nationernas förbund, 1931.

Reeves, John Pownall, Day, Colin, Garrett, Richard and Calthorpe, David. The Lone Flag: Memoir of the British Consul in Macao during World War II. Hong Kong: Hong Kong University Press, 2014.

Reginbogin, Herbert R. Faces of Neutrality: A Comparative Analysis of the Neutrality of Switzerland and other Neutral Nations during WW II. Berlin: Lit Verlag, 2009. 


\section{Bibliography}

Reischauer, Edwin O. Japan: The Story of a Nation. 4th ed. New York: Alfred A. Knopf, 1990.

Roberts, Michael. Sweden as a Great Power 1611-1697: Government, Society, Foreign Policy. London: Edward Arnold, 1968.

Rodao, Florentino. Franco y el Imperio Japonés [Franco and the Japanese Empire]. Barcelona: Plaza \& Janés, 2002.

Roosevelt, Franklin D., Fireside Chat. Online by Gerhard Peters and John T. Woolley, The American Presidency Project, (n.d.) https://www.presidency.ucsb.edu/node /209990.

Ross, John. Neutrality and International Sanctions: Sweden, Switzerland, and Collective Security. New York: Praeger, 1989.

Sai, David Keanu. "Hawaiian Neutrality: From the Crimean Conflict through the Spanish-American War." Paper presented at the University of Cambridge, UK, Centre for Research in the Arts, Social Scineces and Humanities, Sovereignty and Imperialism: Non-European Powers in the Age of Empire, September 10-12 (2015).

Salmon, Patrick. Scandinavia and the Great Powers 1890-1940. Cambridge: Cambridge University Press, 2002.

Sandler, Rickard. Ett utrikespolitiskt program [A program for foreign policy]. Stockholm: Tiden, 1934.

—. Svenska utrikesärenden. Anföranden 1934-1935 [Swedish foreign affairs. Speeches 1934-1935]. Stockholm, 1936.

—. Strömväxlingar och lärdomar: utrikespolitiska anföranden, 1937-1939 [Changing currents and lessons learned: speeches on foreign policy, 1937-1939]. Stockholm: Tiden, 1939.

Seidensticker, Edward. Tokyo Rising: The City Since the Great Earthquake. Tokyo: Knopf, 1990.

Shigemitsu, Mamoru. Japan and Her Destiny: My Struggle for Peace. Edited by Francis S.G. Piggot. Translated by Oswald White. London: E.P. Dutton \& Co., 1958.

Shinohara, Hatsue. Kokusai renmei: Sekai heiwa e no yume to zasetsu [League of Nations: The dream of world peace and how it was shattered]. Tokyo: Chūō Kōron Shinsha, 2010.

Sibre, Olivier. La Saint-Siège et l'Extrême-Orient (Chine, Corée, Japon): De Léon XIII à Pie XII (1880-1952) [The Holy See and the Far East (China, Korea, Japan): From Leo XIII to Pius XII (1880-1952)]. Rome: École Française de Rome, 2012.

Six, Franz Alfred, ed. Dokumente der Deutschen Politik: Das Werden des Reiches [Documents of German Politics: The Establishment of the Reich] vol. 7. Berlin: Junker und Dünnhaupt, 1940.

Slackman, Michael Target: Pearl Harbor. Honolulu: University of Hawaii Press, 1991. Slavinsky, Boris. The Japanese-Soviet Neutrality Pact: A Diplomatic History, 19411945. Translated by Geoffrey Jukes. London: RoutledgeCurzon, 2004.

Steckzén, Birger. Bofors: En kanonindustris historia [Bofors: The history of a cannon industry]. Stockholm: Esselte, 1946.

Sveriges socialdemokratiska ungdomsförbund [Swedish Social Democratic Youth League]. "Protokoll fört vid Sveriges socialdemokratiska ungdomsförbunds sjunde ordinarie kongress i Stockholm den 11-15 nov. 1934" [Minutes from the 7th ordinary congress of the Swedish Social Democratic Youth League in Stockholm, November 11-15, 1934]. Stockholm, 1935. 
Swedish Academy of Science. Sveriges Statskalender för året 1942 [Sweden's State Calendar for 1942]. Edited by Vetenskapsakademin [Academy of Science]. Uppsala: Almquist \& Wiksells, 1942.

Taube, Carl. Kriget som inte var något krig. Som krigskorrespondent $i$ Manchuriet 18 september 1931-9 mars 1932 [The war that wasn't a war. As a war correspondent in Manchuria, 18 September 1931-9 March 1932]. Stockholm: Bonnier, 1932.

Tōgō, Shigenori. The Cause of Japan. Westport: Greenwood Publishing Group, 1977.

Tōyō Keizai Shinpōsha, ed. Nippon bōeki seiran [Japanese trade survey]. Tokyo, 1935.

Traung, Olof. Dan Broström: 1870-1/2-1920.: Några kapitel sjöfartshistoria utgivna med anledning av 50-årsdagen [Dan Broström 1870-February 1-1920 : A few chapters of naval history, published on the occasion of his 50th birthday]. Gothenburg: Nautics, 1920.

Trepp, Gian. Bankgeschäfte mit dem Feind: Die Bank für Internationalen Zahlungsausgleich im Zweiten Weltkrieg: Von Hitlers Europabank zum Instrument des Marshallplans [Banking with the enemy: The bank for international settlements in the Second World War: From Hitler's Europe bank to an instrument of the Marshall plan]. Munich: Rotpunktverlag, 1997.

Tsurumi, Shunsuke. "Chishikijin no sensō sekinin" [The intellectual's responisibility for the war]. Chūō kōron 71, no.l (January 1956): 57-63.

- An Intellectual History of Wartime Japan. London: KPI, 1986.

Unno, Yoshirō. Kokusai renmei to Nihon [The League of Nations and Japan]. Tokyo: Hara Shobō, 1972.

Wahlbäck, Krister. Finlandsfraigan i svensk politik 1937-1940 [The Finnish question in Swedish politics, 1937-1940]. Stockholm: Norstedt, 1964.

Walters, Francis Paul. A History of the League of Nations. London: Oxford University Press, 1965.

Wang, Jianlang. Unequal Treaties and China. Hong Kong: Enrich Professional Publishing, 2015.

Weinberg, Gerhard L. Hitler's Foreign Policy 1933-1939: The Road to World War II. New York: Enigma Books, 2010.

Wetterberg, Gunnar. Wallenberg: The Family That Shaped Sweden's Economy. Möklinta: Gidlunds Förlag, 2014.

Wilson, Sandra. "Rethinking the 1930s and the '15-Year War' in Japan." Japanese Studies 21, no. 2 (2001): 155-164.

Wolfers, Arnold. Discord and Collaboration: Essays on International Politics. Baltimore: Johns Hopkins University Press, 1962.

Yoshitake, Nobuhiko. Nihonjin wa Hoknō kara nani wo mananda ka. NihonHokno seiji kankeishi nyūmon [What did the Japanese learn from Scandinavia? An introduction to the history of Japanes-Scandinavian political relations]. Tokyo: Shinhyōron, 2003. 
Appendix 


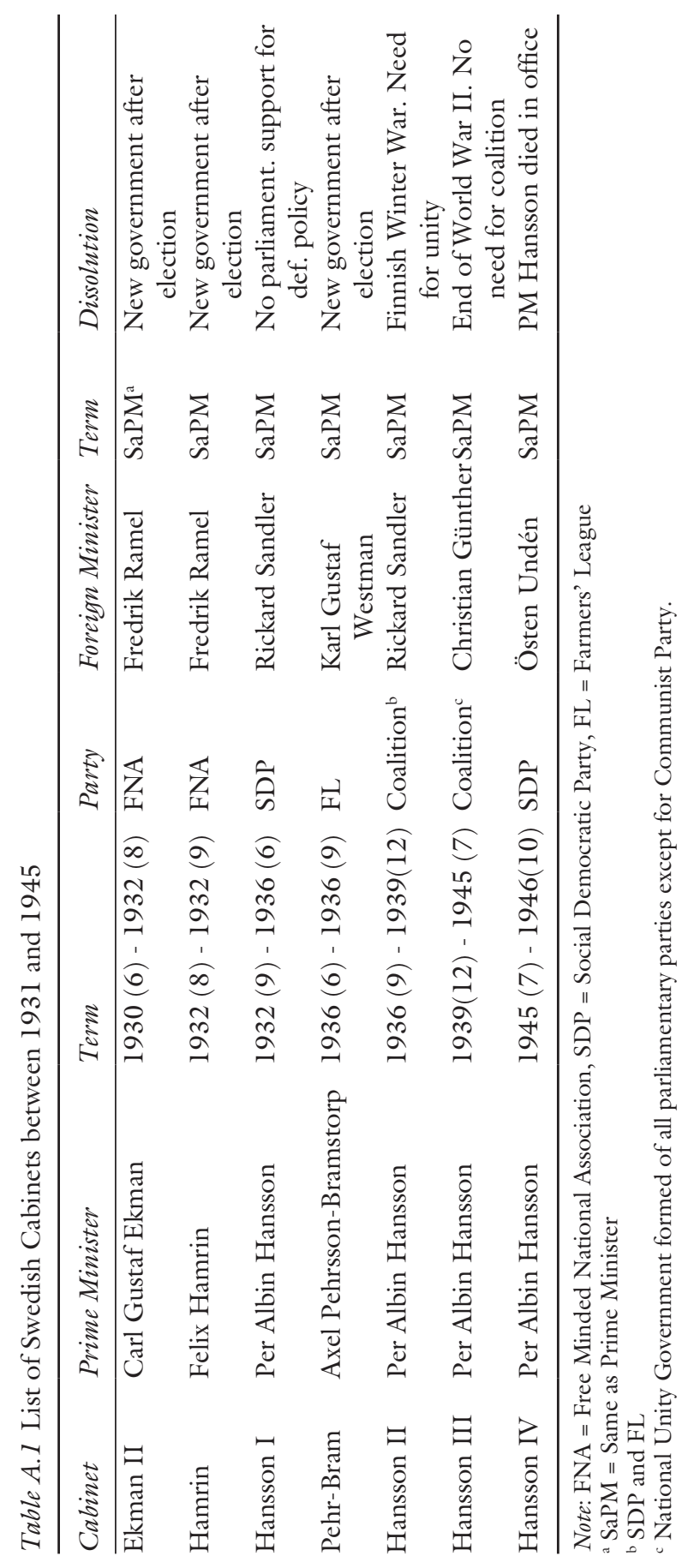




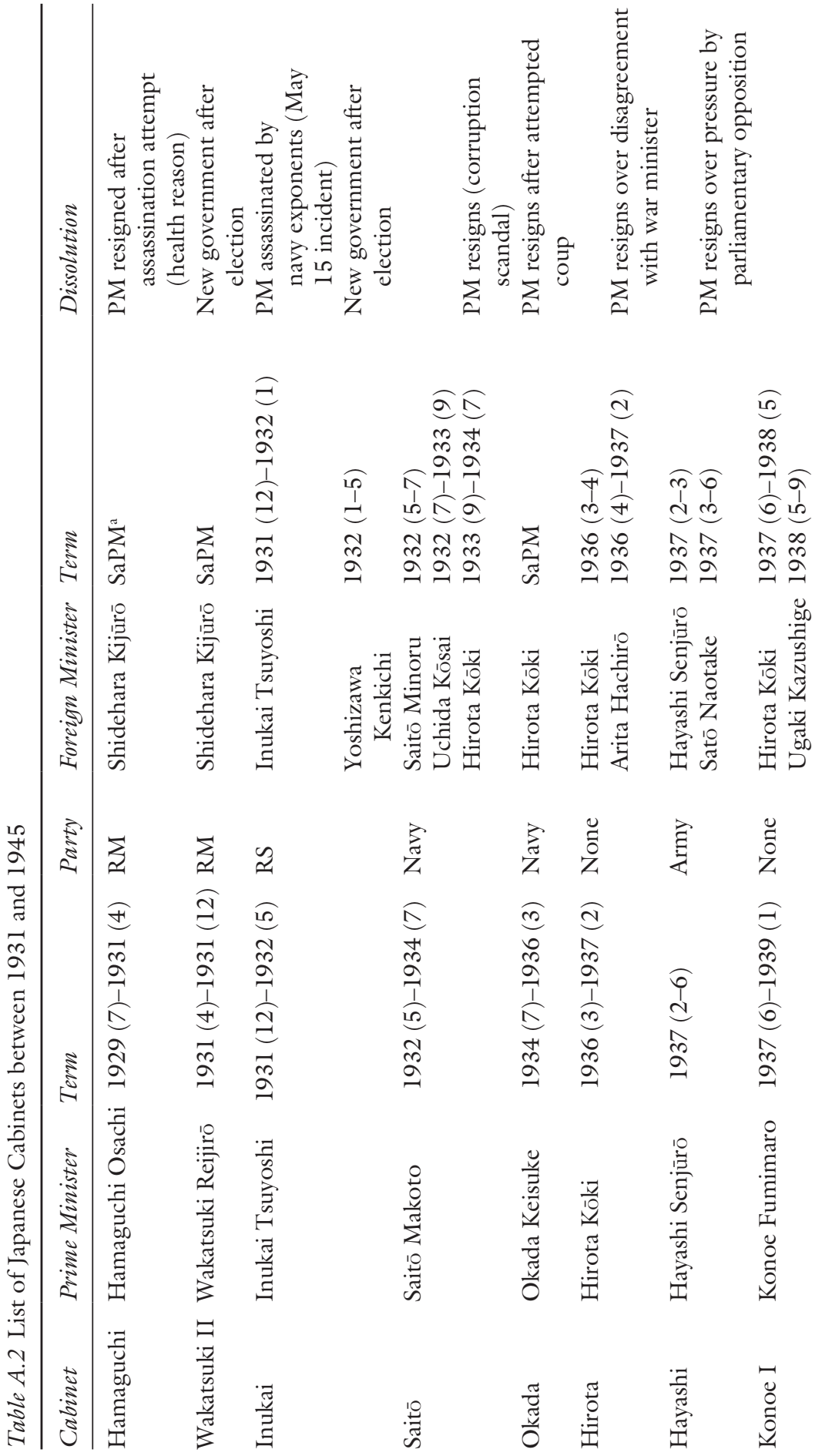




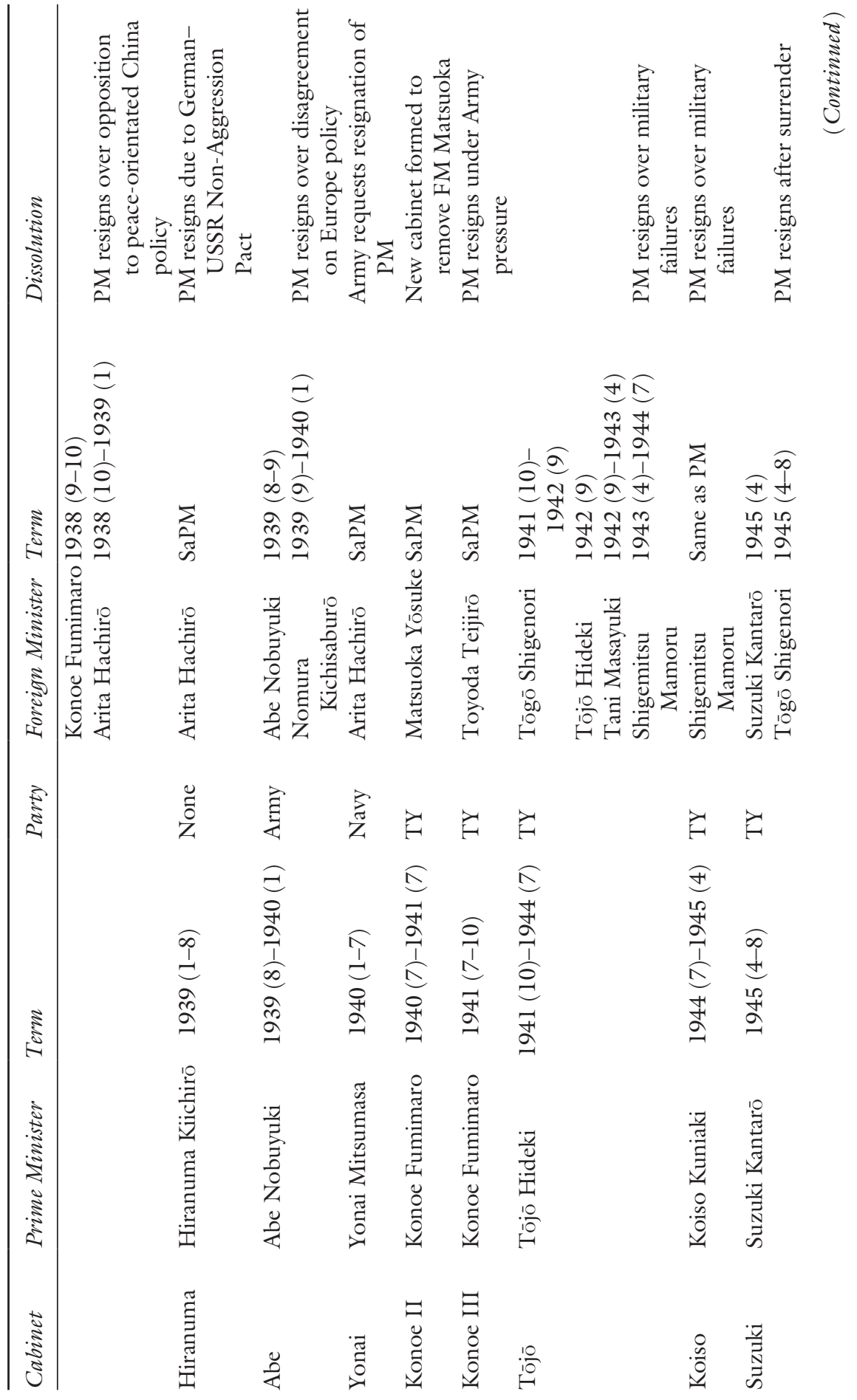




\section{Speech by Eliel Löfgren at the League of Nations Assembly, March 5, 1932}

This speech was held by Eliel Löfgren at the League of Nations to express the opinion and views of the Swedish Government on the "Mukden Incident." While Löfgren spoke in French, the following is the English translation as to be found in the League of Nations Official Journal, "Records of the Special Session of the Assembly: Convened in virtue of Article 15 of the Covenant at the Request of the Chinese Government.” Geneva, Vol. I, 1932.

In his speech during the general discussion of the Disarmament Conference, Baron Ramel, the Swedish Minister for Foreign Affairs, drew attention to the growing anxiety with which, in Sweden as in many other countries, events in the Far East are being followed, involving, as they do, a serious threat to the results obtained at Geneva in the organization of peace. On behalf of the Swedish Government, he expressed the most earnest hope that peace might be promptly restored by the energetic action of the League and the Powers principally concerned.

From that time until the last few days the position in the Far East has become worse, and although the news appears to be contradictory, no one can deny that what is taking place is war in everything but name. At this moment I will say nothing as to what has been done by the organs of the League to put an end to this deplorable conflict. I note, however, with satisfaction that, from the first phase of the conflict, the Council has laid stress on the fact that it could not be solved satisfactorily without the withdrawal of the troops concerned. No one can deny, especially after the report by the Committee of the League at Shanghai dated February 3rd, that the military means employed in the conflict between China and Japan are not in conformity with existing treaties.

Sweden, for her part, has maintained on several occasions during the League discussions that the provisions of the Covenant prohibiting the use of armed force retain their entire validity whether either of the Parties describes the use of armed force as war or not. Without wishing at this moment to give any opinion on the respective claims underlying the conflict, I wish to state that, in the opinion of the Swedish Government, the landing of troops and their use in military operations on the territory of another Power are contrary to the provisions of the Covenant and of the Pact of Paris. Any such attempt to extend the conception of legitimate defence in the manner adopted in the present case would render it impossible to maintain any legal international order.

Consequently, my Government unhesitatingly gives its support to the note addressed to Japan by the twelve members of the Council on February 16th last, and, in my opinion, the Assembly should endorse this appeal. I realise the complicated nature of the conflict and the special conditions prevailing in the Far East. These special circumstances cannot, however, be invoked by one of the Parties as an excuse for evading the procedure of conciliation and arbitration laid down in the Covenant. 
It is, however, evident that, at the present time, the first duty of the special Assembly is to obtain, not only the cessation of firing, but also the definite cessation of hostilities. The latter is an indispensable condition in order that the organs of the League may contribute to a peaceful settlement of the SinoJapanese conflict. The cessation of hostilities should, however, take place in such a manner that the position of the Parties to the dispute may not, in view of the settlement of the dispute, be influenced by military pressure and that invasion of Chinese territory may be stopped. I welcome the appeal adopted yesterday by the Assembly as first step towards this result.

I wish, however, to point out that, once hostilities have ceased, it will naturally be the essential duty of the League to ensure the peaceful settlement of the conflict in the spirit of the Covenant. In this connection I may recall the remarks contained in $\mathrm{M}$. de Brouckère's report, which was adopted as a valuable guide by the 1927 Assembly.

At this moment a heavy responsibility weighs on the special Assembly of the League and on all the States taking part in it. As M. Hymans, the President of the Assembly, stated in his opening speech, we must conscientiously seek for ways and means of restoring concord through justice. It is true that small countries like ours have less possibility than the Great Powers of influencing the course of events; but our interest in the maintenance of legal international order is all the greater.

If the League does not succeed, in present circumstances, in establishing peace based upon justice, the proper and loyal application of its own constitution, there is a danger of the more or less complete collapse of those ramparts which we have built up together with so much patience and zeal in order to prevent force from supplanting justice.

\section{Reports by Nils E. Ericson on POW Camp Visits, 1942}

The following documents are the records of Ericson's first visits to the POW camps in Nagasaki, Zentsūji, and Kobe (originals in: BA, 230033.2, F2b, I). The documents have been retyped for this publication. All mistakes (grammar and spelling) are reproduced.

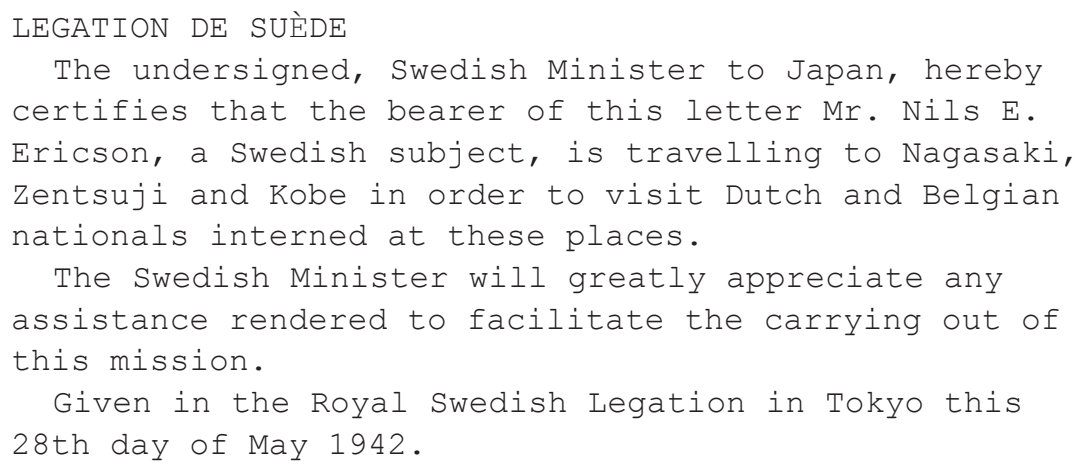




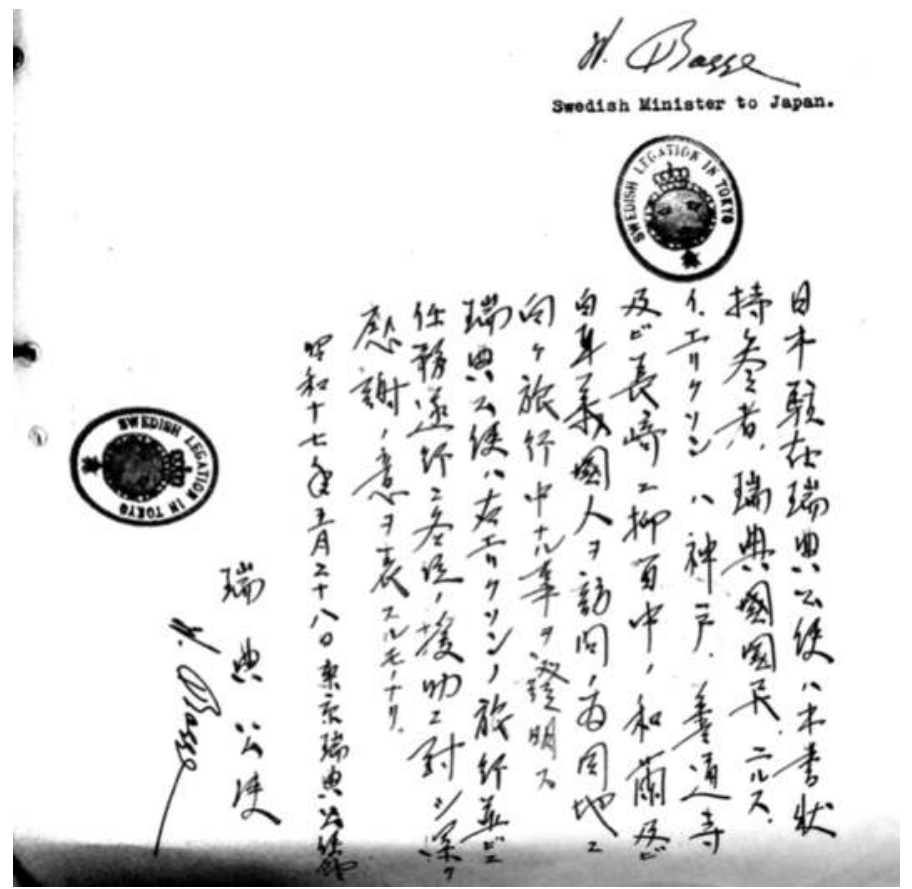

Tokyo, the 3rd June 1942.

H. Ex. Envoyee W. Bagge, Royal Swedish Legation Tokyo

Your Excellency,

I wish to inform Your Excellency, that I returned yesterday from my trip to Nagasaki, Zentsuji and Kobe. As instructed I requested permission from the Okayama Police Station to visit the interned Belgian missionary at Hiroshima, but as there was no mention of this visit neither in the letter from Gaimusho nor in the police permit, this request was refused. I attach my reports on the visits to the above mentioned camps.

I returned herewith attached documents received before my departure:

1 letter from Gaimusho, introduction

1 " " Legation, "

2 " copies from Legation

1 p.m. from Legation

I also enclose my travelling account 


\section{Appendix}

amounting to $¥ 1.101: 00$ and $¥ 899$ :00 in cash remaining from the amount of $¥ 2.000: 00$ received from the Legation.

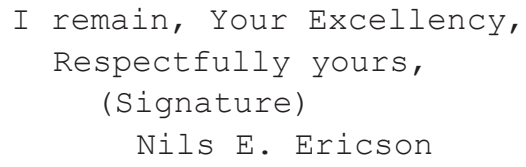

Tokyo, the 3rd June 1942.

Report No.1 - visit to Nagasaki.

The enemy nationals are interned at the St. Marie School on the outskirts of Nagasaki bity. The school is located high up on the hills in very pleasant surroundings. Chief Inspector Hamamoto of the Foreign section of Nagasaki Ken-cho is in charge of the camp and he has made a special trip to inspect the camps in Tokyo, Yokohama and Kobe. He told me that he has tried to make his camp better than the others in every respect and I am pleased to report that he has succeeded very well. The interned were unanimous that they were treated very well, received sufficient and good food (cooked by some of the interned Canadian priests). I also partook in one of their meals, which consisted of peasoup, braised beef with fried eggs and potatoes, bread, milk and fruits. There were about 30 people interned, and they had complete freedom to play games in the school compound, read, play cards and they were even to a certain extend allowed to write letters and to receive letters and parcels. The wifes were permitted to visit there husbands daily.

The interned seemed not to know anything about the evacuation and I made the Belgian and Dutch subjects aquainted with the evacuation scheme in general, their probable destination and also about the baggage regulations as far as known at present. I also wish to mention that there have been no official visitors there before. 
BELGIAN subjects. Contrary to the Legation list I found two Belgian subjects interned at this camp, namely Messrs. Pourbaix and Somers.

1) Mr. Paul Pourbaix. He requests that the Legation try to obtain permission from the proper authorities for him to return to his home as soon as ever possible on the plea that he is suffering from high blood preasure for which reason he must have special $x x$ diet, which is impossible to get at the camp. I have discussed the question with Mr. Hamamoto, who states that a Japanese physician has examined him and that he expressed the opinion that there is no immediate need for such special treatment. However, in view of the delayed evacuation, it might be advisable to consider some action in this matter.

Mr. Pourbaix confirmed that neither he nor his wife desire to evacuate and he also stated that he has sufficient funds.

2) Mr. Julien Somers. He confirms that he wishes to remain in Japan. He has ample funds and is not in need of funds at present, but is anxious to know if he can count on his pension in the future.

$-2-$ Report No.1

He receives a pension from the Netherlands Government, but has not received anything since the outbreak of the war. I have discussed this question with our Consul at kobe and I find that he has received funds from the Legation to effect payment of pensions, including Mr. Somers, but that he cannot pay out this money without permits from the Finance Department.

NETHERLANDS subjects. There were four Netherlands subjects interned, as per the Legation list. I presented them and the Belgians with the following items:

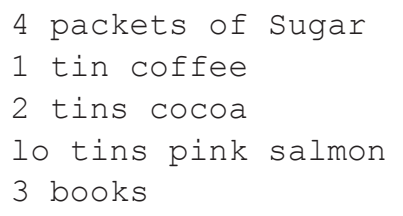

and I have been asked to convey their apprechiation for these gifts as well as their gratitude for the courtesy 


\section{Appendix}

in sending a special respresentative of the Legation all the way down to Nagasaki.

1) G.W. Calicher is anxious to be evacuated, but he insists upon that his wife must go with him. The reason for his fear in this respect is that she still, despite the fact that she is legally married and holds a Netherlands passport, is contained in the village register at Minami Takigun, Nagasaki-ken as a Japanese subject. She wishes, if possible, to retain her dual registration, but if this is impossible, she wishes to cancel her Japanese citizen ship, as she naturally desires to follow her husband. He asks if an answer could be given on this point and he also desires an assurance that whatever happens his wife will be evacuated with him. He stated that his passports had expired on May 6th, but as same were kept by Ken-cho, he was unable to have them prolonged. By arrangement with Mr. Hamamoto I obtained the two passports, but unfortunately I received them at the very last moment and I now find that he was mistaken and that same are valid until next year. I regret this unavoidable mistake and ask you to return them to Foreign Section of Nagasaki Ken-cho. At the same time I was able to recover some private documents, that the Ken-cho had taken from him. He further desired to obtain from the Netherlands Consulate-General in Kobe a certificate, that he has only obtained his pension for November 1941 (about $¥ 600: 00$ ) and also part for December, or $¥ 270: 00$. He must have this certificate to prove his claim for further payments after his evacuation. I have discussed this matter with Mr. Pennink, who promissed to make the certificate and to send same through our local consulate.

2) Mr. D.H. Grootes requested an advance of money as he only had a small sum left. He asked for and received $¥ 250: 00$, receipt for which I will attach

3) to the statement of accounts. His passport expired on 6th March 1942 and I enclose the same for 
extention. It should be returned through Nagasaki Ken-cho.

He is very anxious to be evacuated.

4) K.L. van Teyn. He does not desire to be evacuated nor does his wife. He was worried about various documents including marriage certificate, insurance policy etc. taken by the Kencho, but I received an assurance from Mr. Hamamoto that everything would be returned at the time they are set free. He holds an endowment policy with the Hollandske Societee for Lifforsakring (spelling?), Amsterdam, on which he received Gil. 250:00 for each period of 3 months, but he has not received anything for the last 2 years, and is anxious to know if arrangements for payments could be made through the London Government.

5) P.G. Wisse desires to be evacuated. As he only had $¥ 10: 00$ left, he requested $¥ 200: 00$, which amount was handed to him. His receipt will be attached to my statement of travelling expenses.

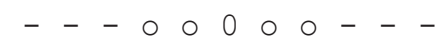

3) cont. His and his wifes joint passport, which expired on the 14th July 1929, has never been renewed. He asks that the same is prolonged or new passports made out. I enclose the same and wish to add, that should photographs be required, same could be obtained through the Nagasaki Kencho.

1) cont. Mrs. Calichers address is not as stated on the Legation list, but as follows:

c/o Mrs. Tsune Hashibe, 21, Ouraizuno-machi, Nagasaki.

Tokyo, the 3rd June, 1942

Report No.2 - visit to Zentsuji.

I visited the war prisoners camp at Zentsuji in the morning of May 30 th and all the prisoners were busily engaged to clean the camp, as the Prime Minister, General Tojo was expected that afternoon. I was met with great courtesy and I was introduced to the Commandant of the camp and his assistant. They both seemed 


\section{Appendix}

to be retired officers called up for special service. Some disused military barracks have been turned in to a camp and there were about 450 war prisoners there, chiefly Americans from Guam. The general impression was that they were not very happy, as they have no occupation and also as the food does not seem to suit them. They receive the same ration as Japanese soldiers and the ingrediences are delivered to their kitchen and they themselves can make the food to suit their own taste. One of the nurses from Guam, who has now been transferred to the Eastern Lodge in Kobe, were I met her, told me that most of the prisoners have lost 10 - 20 lbs during the first two months at the camp.

To occupy themselves they have lectures on various subjects, they keep rabbits and try to do some gardning. They have their own shoe repair shop, tailoring shop, barber etc. and they also have a canteen, which however is only open for a few hours a day, as they have very little to sell there.

I inspected the whole camp and I found that they were housed according to their rank. The commanding officers had rooms in the administration building and they were generally 2 persons in each room, the subalterns were generally 8 in one room and the ratings were in larger rooms.

The two Netherlands subjects in the camp were (please note the spelling of their names, as the spelling on the Legation list is wrong):

Looijen, Abraham Arnoldus Naval Engineer with Commanders rank.

Beudeker, Herman, Diederik Lieutenant of the Navy

They were both on a Netherlands sub-marine, which was captured at an island north of New Zealand and were together with the rest of the crew taken to Hongkong, were they arrived in under-pants and slippers. They received some clothes from the British stores there and for some unknown reason only the two of them were brought to Japan and the rest of the crew was left at Hongkong. They were both most anxious to inform their wifes that they are safe and if direct communication with the Netherlands East Indies is impossible, they wondered if it would not be possible to send a message through the International Red cross. The addresses of their respecttive wifes are as follows: 
Mrs. T. K. T. Looijen,

47, Tegalsarie,

Soerabaia.

Mrs. C. L. Beudeker,

8, Sedepmalemweg,

Soerabaia.

Mr. Beudeker was also most anxious to send a message to his parents, address as below, to the effect that he is safe.

Mr. Beudeker,

52, Montfoorlaan,

The Haag.

They told me that they found the winter very cold as they had no warm under clothes and if it is possible to obtain some under clothes for the coming winter they, should be very grateful. They are respectively 169 and $184 \mathrm{~cm}$ in high and both are very lean. They further asked me to try to find an English-Dutch dictionary for them and I am pleased to report that Mr. Pennink has kindly donated this dictionary, which I attach with a request that it is forwarded to the commandant of the prisoners camp at Zentsuji. I have already inquired if the dictionary and the below mentioned books could be send direct in this manner and the answer was affirmative. As they are being paid the same salaries as Japanese officers of corresponding rank, they have money and they have asked us if we could try to buy the following books for them. By the permission of the camp authorities, they will be in the position to remit by postal money order the cost of the books.

Looijen Technical book re steam engines

" " " turbines

" pocket book

The three books are by DUBBEL and are written in German

Beudeker Higher mathematics Books on navigation

No special books have been specified and there is no objection to German or English language. 


\section{Appendix}

I presented them with one large slab of chocolate each, 38 tins of Salmon and 4 tins of sardines for which they were extremely grateful and they have both asked me to convey their apprechiation. By special permission I was also allowed to give them three books (novels).

$$
\text { - - - } 00000 \text { - } 0 \text { - }
$$

Tokyo, the 3rd June 1942.

Report No.3 - visit to Kobe.

All below mentioned visits were made together with our acting Consul - Mr. L. Wiren, who very kindly held himself at my disposal during my stay there. In accorande with instructions we tried our very best to obtain permission to visit the four Netherlands subjects in prison, but this proved impossible, as prisoners cannot be visited before the judgement has been passed. The matter was discussed over the 'phone between the judicial officials and the Foreign Section of the Kencho, but as the prison was referred to as "amari omoshiroi tokoro ja nai", they decided to make the above excuse for not giving the permission. All interned people in Kobe, both officials and civi- lians seem to be treated quite well, but the rules about visits have become stricter. They were all well informed regarding the evacuation, but the civilians were worried as they had been told by the police that they could not bring any books, documents or other written papers with them on the evacuation ship. I wish to report on the individual visits as follows: Netherlands Consulate-General. I met Mr. J.B.D. Pennink, the Consul General, his wife, Mr. de Voogd, Censul and two other consulate officials, who were all interened in Mr. Pennink private house. I have already in my previous reports mentioned some subjects I discussed with Mr. Pennink. There are, however, two other subjects on which he is most anxious to obtain some more definite information and they are as follows:

1) Baggage. He stated that he and the other officials have together 120 cubic meters or more of furniture etc. and he is anxious to know, if the ship is really coming to Kobe to fetch the luggage. If not, he is anxious to send all their cases and heavy luggage by 
freight train to Yokohama, but as such forwarding would require several weeks, he trusts that a definite answer to this question can be given in the very near future.

2) Insurance. He has been informed through Mr. Wiren that insurance can be effected abroad, but as no detailed information has been given, he asks to be informed xxx about the name of the company, the rate of premium etc.

Norwegian Consulate. The Kencho was very unwilling to give their permission for us to visit the Norwegian Consulate, as they have no information from Tokyo, that Sweden is permitted to look after the Norwegian interests and also as nothing was mentioned in the Gainmusho letter that I was supposed to visit this Consulate. However, we

finally succeeded to get the permission and we met Mr. T. B. Gansmoe and his wife. They expressed their great pleasure at the news that they will now be looked after by the Swedish Government and they have asked me to convey greetings and thanks for all the trouble Your Excellency has taken on their behalf. There were two thing Mr. Gansmoe has asked me to convey, namely:

1) that O.E.N. Samuelsen, 69 years old and his Japanese wife, residing at Sano, Awaji have been informed by the police at Awaji, that they must evacuate. They are both anxious to remain, as they have property both at Awaji and in Kobe and as they have sufficient means of support. Mr. S. is a retired official of the Chinese Maritime Customs. He went to Kencho in Kobe on the 1st inst. regarding this police order and they confirmed that he must evacuate. He now requests through Mr. Gansmoe, that everything possible may be done to permit him to remain in his home in Awaji. In view of his age I consider that his request is reasonable.

2) that he wishes to point out that a Norwegian subject residing in Nagasaki - Mr. Albretson is anxious to evacuate, probably with his wife. If they are not on the evacuation list, he asks 


\section{Appendix}

that investigation is made and their names added to the list.

Eastern Lodge, Kobe.

Belgian subject:

1) Joseph Spae states that he under no circumstances wishes to evacuate unless he is forced to do so. He wonders if it would not be possible to make an other request to Gaimusho that he may be allowed to return to Peking, as there is not a single missionary there, who can speak Japanese for which reason he ought to be very useful. If this is quite impossible, he wishes to return to Kyoto, where he is studying for a Doctors degree and where $\mathrm{xx}$ he is publishing a book.

Netherlands subjects:

1) C.W. Brand wishes to evacuate only on the condition that his chief - Mr.van Ketel is allowed to go. Otherwise he considers it his duty to remain to give him any assistance that he can

2) H.J.Heuperman are not on the evacuation list, but they are now anxious to be evacuated and have requested that their names be placed on the list

3) W. Lengkeek requests that we cable his principal (address below) for permission for him to evacuate, as he otherwise feels obliged to remain, as they have stocks of considerable value in Japan. Address: PRINS CARE WINTER COMPANY, 106 WALLSTREET, NEWYORK

4) H. Meyer states that he has been informed by the police that his name has been taken off the

$$
-3-
$$

evacuation list, as he has a court case pending against him. The nature of the case was not disclosed, but I understand that it concerns transactions in exchange etc. He is very anxious to evacuate and requests that everything be done to assure his evacuation.

5) A.C.van Nahuys confirms wish to evacuate. He is also anxious to get news from his wife. Latest 
address: Mrs. G.F. van Nahuys c/o Mrs. Kilsdonk, 16 Mampangweg, Batavia.

6) H. Olk has lost his pass port and requests that a new one is made out. He states that he is personally known to the Netherlands acting Minister. The particulars required for the passport are as follows:

$\begin{array}{ll}\text { Birth p lace: } & \text { Amsterdam } \\ \text { " date: } & \text { 10/7/1898 } \\ \text { Domicile: } & \text { Japan } \\ \text { Shape face: } & \text { Round } \\ \text { Colour eyes: } & \text { Greyish-green } \\ \text { Special marks: } & \text { Spectacles }\end{array}$

As he was employed by a Japanese firm he is worried about getting some work after the evacation and asks if it would be possible to notify his friend - Mr. Gielgud, Secretary-General of the International Red Cross, Geneva that he would much apprechiate some work upon arrival at the destination of the evacuation. P.S. He will send photographs for the passport through Mr. Wiren in a few days time.

7) J.G. Oost Lievense wishes to evacuate only on the condition that his chief - Mr. Holtkamp is allowed to go. Otherwise he considers it his duty to remain to give him any assistance that he can.

8) C.T. Rolandus confirms wish to evacuate.

9) O.J. Rookmaaker could not be visited, but Mrs. R. definitely states that they do not wish to evacuate (acc. To Mr. Wiren)

10) B. Spanjaard confirms that he and his wife wish to evacuate together. He also stated that he has now been able to arrange for the total payment of the fine and that required permits have been obtained, but that it might take some time before he can make the final payment. 


\section{Appendix}

Table A.3 List of Swedish representation of foreign interests in World War II

\begin{tabular}{|c|c|c|}
\hline Interests of Country & Represented in Country/Territory & Starting Date \\
\hline Argentina & Bulgaria & $1944-02-07$ \\
\hline Argentina & France Vichy & Unknown \\
\hline Argentina & Germany & Unknown \\
\hline Argentina & Hungary & Unknown \\
\hline Argentina & Japan & 1944-01-28 \\
\hline Argentina & Romania & 1944-02-07 \\
\hline Belgium & Japan & $1941-12-12$ \\
\hline Belgium & Thailand & $1942-03-06$ \\
\hline Bolivia & Japan & $1942-02-06$ \\
\hline Brazil & Romania & $1945-07-31$ \\
\hline Bulgaria & Argentina & 1944-06-02 \\
\hline Bulgaria & Iran & $1941-09-19$ \\
\hline Bulgaria & Japan & $1944-11-24$ \\
\hline China & Denmark & 1941-09-19 \\
\hline Denmark & Japan & $1944-05-25$ \\
\hline Denmark & Soviet Union & $1941-06-28$ \\
\hline Finland & Australia & Unknown \\
\hline Finland & British Empire $^{a}$ & $1941-07-31$ \\
\hline Finland & Burma & $1941-07-31$ \\
\hline Finland & Ceylon & 1941-07-31 \\
\hline Finland & China & $1944-9$ \\
\hline Finland & Egypt & $1942-01-16$ \\
\hline Finland & Faroe Island & 1942-01-01 \\
\hline Finland & Iraq & $1942-01-23$ \\
\hline Finland & Italy & 1944-08 \\
\hline Finland & Japan & 1944-09-30 \\
\hline Finland & New Zealand & $1941-07-31$ \\
\hline Finland & Romania & $1945-03$ \\
\hline Finland & South Africa & Unknown \\
\hline Finland & Soviet Union & $1941-06-28$ \\
\hline France & Mexico & 1942-11-01 \\
\hline France & Port Louis (Mauritius) & $1942-02-02$ \\
\hline Germany & Egypt & 1939-09-06 \\
\hline Germany & France & 1939-09-03 \\
\hline Germany & Greece & 1941-04-09 \\
\hline Germany & Iceland & $1940-05-17$ \\
\hline Germany & Iran & $1941-08-30$ \\
\hline Germany & Mexico & $1941-12-12$ \\
\hline Greece & Hungary & $1945-04-30$ \\
\hline Greece & Japan & 1942-08 \\
\hline Greece & Territories in Far East & $1942-08$ \\
\hline Honduras & Japan & 1942-04-17 \\
\hline Hungary & Argentina & 1944-02-11 \\
\hline Hungary & Australia & Unknown \\
\hline
\end{tabular}

(Continued) 
Table A.3 (Continued)

\begin{tabular}{|c|c|c|}
\hline Interests of Country & Represented in Country/Territory & Starting Date \\
\hline Hungary & Brazil & 1942-04-17 \\
\hline Hungary & British Empire & 1941-04-09 \\
\hline Hungary & Chile & $1943-05-27$ \\
\hline Hungary & Dutch East Indies & 1940-06-11 \\
\hline Hungary & Egypt & $1941-12-19$ \\
\hline Hungary & Fiji and Cyprus ${ }^{\mathrm{b}}$ & Unknown \\
\hline Hungary & Finland & 1944-09-30 \\
\hline Hungary & Iran & 1941-09-19 \\
\hline Hungary & Italy & $1944-7$ \\
\hline Hungary & New Zealand & Unknown \\
\hline Hungary & Paraguay & 1942-05-08 \\
\hline Hungary & Romania & 1944-09-14 \\
\hline Hungary & Tangier Morocco & 1941-04-30 \\
\hline Hungary & Uruguay & 1942-05-08 \\
\hline Hungary & USA & $1941-12-12$ \\
\hline Hungary & Iraq & $1941-11-21$ \\
\hline Iceland & Germany & 1940-07-02 \\
\hline Iceland & Italy & 1940-07-19 \\
\hline Iran & Bulgaria & $1941-10-10$ \\
\hline Iran & Hungary & 1942-05-29 \\
\hline Iran & Romania & $1941-10-10$ \\
\hline Italy & Japan & 1945-07-31 \\
\hline Japan & Belgium & 1944-06-10 \\
\hline Japan & Bolivia & 1945-05-04 \\
\hline Japan & Brazil & 1945-05-04 \\
\hline Japan & Bulgaria & $1944-11-24$ \\
\hline Japan & Burma & $1941-12-12$ \\
\hline Japan & Ceylon & $1941-12-12$ \\
\hline Japan & Chile & 1943-01-29 \\
\hline Japan & Costa Rica & 1945-05-04 \\
\hline Japan & Denmark & 1945-06-29 \\
\hline Japan & Finland & 1944-09-30 \\
\hline Japan & Hawaii & $1941-12-12$ \\
\hline Japan & British India & $1941-12-12$ \\
\hline Japan & Iran & 1945-01-19 \\
\hline Japan & Iraq & 1945-01-19 \\
\hline Japan & Lebanon $^{\mathrm{c}}$ & 1945-05-04 \\
\hline Japan & Mexico & 1945-06-29 \\
\hline Japan & Netherlands & $1941-12-12$ \\
\hline Japan & Nicaragua & 1945-05-04 \\
\hline Japan & Paraguay & 1945-05-04 \\
\hline Japan & Peru & 1945-05-04 \\
\hline Japan & Romania & 1944-11-17 \\
\hline
\end{tabular}

(Continued) 


\section{Appendix}

Table A.3 (Continued)

\begin{tabular}{|c|c|c|}
\hline Interests of Country & Represented in Country/Territory & Starting Date \\
\hline Japan & South Africa & $1941-12-12$ \\
\hline Japan & Switzerland & $1945-11-02$ \\
\hline Japan & Turkey & 1945-01-19 \\
\hline Japan & Uruguay & $1945-05-04$ \\
\hline Mexico & France & $1942-11-13$ \\
\hline Mexico & Germany & $1941-12-12$ \\
\hline Mexico & Italy & $1941-12-12$ \\
\hline Mexico & Japan & $1941-12-12$ \\
\hline Netherlands & Denmark & 1940-05-10 \\
\hline Netherlands & Finland & $1941-06-28$ \\
\hline Netherlands & France Vichy & $1940-09-13$ \\
\hline Netherlands & Germany & $1940-05-10$ \\
\hline Netherlands & Greece & 1941-04-09 \\
\hline Netherlands & Hungary & 1941-04-09 \\
\hline Netherlands & Italy & $1940-06-14$ \\
\hline Netherlands & Japan & $1941-12-12$ \\
\hline Netherlands & Norway & Unknown \\
\hline Netherlands & Romania & $1941-02-14$ \\
\hline Netherlands & Thailand & $1941-12-12$ \\
\hline Netherlands & Belgium & Unknown \\
\hline Norway & Belgium & Unknown \\
\hline Norway & Denmark & $1940-05-07$ \\
\hline Norway & Finland & Unknown \\
\hline Norway & France Vichy & $1940-09-13$ \\
\hline Norway & Germany & 1940-04-09 \\
\hline Norway & Japan & $1942-03$ \\
\hline Norway & Netherlands & Unknown \\
\hline Norway & Romania & 1943-11-19 \\
\hline Norway & Territories in Far East & Unknown \\
\hline Norway & Thailand & $1942-05-22$ \\
\hline Poland & Germany & 1939-09-01 \\
\hline Romania & Argentina & 1944-02-11 \\
\hline Romania & Brazil & $1942-04-17$ \\
\hline Romania & British Empire & 1941-02-14 \\
\hline Romania & Japan & $1944-11-17$ \\
\hline Romania & USA & $1941-12-12$ \\
\hline Slovakia & Iran & $1941-11-21$ \\
\hline Slovakia & Soviet Union & $1941-06-25$ \\
\hline South Africa & Germany & 1939-09-06 \\
\hline Soviet Union & Denmark & $1941-06-28$ \\
\hline Soviet Union & Finland & $1941-06-28$ \\
\hline Soviet Union & France Vichy & $1942-03-27$ \\
\hline Soviet Union & Germany & $1941-06-25$ \\
\hline Soviet Union & Hungary & $1941-06-25$ \\
\hline Soviet Union & Italy & $1941-06-28$ \\
\hline
\end{tabular}


Table A.3 (Continued)

\begin{tabular}{lll}
\hline Interests of Country & Represented in Country/Territory & Starting Date \\
\hline Soviet Union & Romania & $1941-06-28$ \\
Soviet Union & Slovakia & $1941-06-25$ \\
\hline
\end{tabular}

Source: Various lists in UDA, 2210.03.1, P19, A.

Notes: Names of countries or territories are standardized, e.g., Siam = Thailand. No differentiation between de jure and de facto mandates. Starting dates are not reliable, use with caution. Some lists in the sources mention different dates for same mandates.

a Refers to British oversee territories, including South and North Rhodesia, Pacific Islands, Cyprus, Hong Kong, the Bermudas, British Honduras, British Guyana, Barbados, Port Castries, Jamaica, the Bahamas, and Trinidad and Tobago.

${ }^{b}$ Unclear why mentioned together.

c French mandate of Lebanon and Syria. 


\section{Index}

Note: Italicized page numbers indicate figures, bold indicates tables and numbers with " $n$ " indicates endnotes in the text.

AB Bofors 48

AB Nobelkrut 48

Abe, N. 102-4, 125, 145

Abyssinia (Ethiopia) 5, 32, 98-100

Acheson, D. 174-5

Addis Ababa $32,177 \mathrm{n} 77$

Adlercreutz, C. 128

Advisory Council on Foreign Affairs 24, $37,39,63,12 \ln 58,128$

after war 181-3

Aftonbladet 127

Algeria 83

Allen, L. 159

Allied Powers 2, 7-8, $1 \operatorname{lnl} 1,94,109$, $137,151,169-70,174,184$

Allies 2, 3, 6, 137, 144, 146, 162

Allmänna Säkerhetstjünsten 128

American Far Eastern Match Co. 69,150

American Federation of Labor (AFL) 67

American War Refugee Board 129

Andorra 9

Anti-Comintern Pact 32, 45-6, 92, 101-2

Aoki, T. 81

Arabia 9

Argentina 10, 79, 133, 140

arms export 41, 44, 59n100-1

Article XVI 36, 42, 72, 98-9; see also

Covenant of the League

Asabi Shimbun 112, 161

Asia 1, 3, 5, 18-19, 23, 37, 41, 75-6, $79,92,103,107,150$

Asker G. 143

Assarsson, V. 165

Association of Free-minded Women 67
Atlantic Ocean 116

Atlas Copco 108

Axis Powers 2, 32, 75, 94, 102, 104, $127-8,151,184$

Bagge, G. 68, 98-9, 113, 115, 131, $133-4,136-40,143-4,146-9$, $151-2$

Bagge, L. 122n69

Bagge, W. 1-2, 4, 1ln2, 70-1, 80-1, 107-11, 108-9, 115, 117-18, 122n69, 126, 153, 159, 159nl, 160-9, 171, 182

Bagge maneuver 1, 159, 174

Baltic Sea 105

Baltic States 3, 94

Bangkok 143

Beck-Friis, J. 75, 82, 107

Belgium 3, 34, 45, 74, 97, 135

Bell, R, G. 111

belligerents $2-7,10,76-7,84,97,103$, $116,127-30,133,146,153,184-5$

Beneš, E. 42

Bergman, S. 29

Bergström, D. 23

Berlin 8, 45-6, 92, 101-4, 111-12

Berlin-Rome-Moscow-Tokyo 104

Bernadotte, F. 129

Bernath, K. 142-3

Bernhard Dieden \& Co 27n21

bilateral diplomacy after fallout 44-6

bilateral relations: international politics 95-6; Japanese protest 41; between Stockholm and Tokyo 8; Sweden with Japan 9

bilateralism $81,105-7,118$ 
bilateralization 107

Blue Papers 37

Boëthius, M.-P. 2

Boheman, E. 5-6, 62, 163

Bolivia 135

Bolshevism 37, 45, 101

Bossert, R. 140

Boxer Protocol 61

Boxer Rebellion (1900) 17

boycott movement 66-9

Branting, H. 39

Brazil's diplomatic relations with Japan 10

British Empire 132

British Government 116

Broström, D. 18

Broström, Tor E. J. 113

Brussels 73-4, 107

BU Intelligence 146

Buck, P. 64

Bulgaria 130

Burma 132

business $32-6,46-9$

Cairo 108

Canary Islands 83

Canton (Guangzhou) 46, 61

Carl Ekman \& Co 27n21, 47, 70, 136

Carlgren, W. 159-60

Cassel, H. 17

Catholics 9

Ceylon 132

C.G. Ekman 33-4, 36, 38-9, 83, 148

Chamberlain, N. 98

Chang Tso-lin (Zhang Zuolin) 32, 48

Chiang Kai-shek 31, 41, 48, 61-2, 70, $75,84,89$ n $88,93,103-4,125,181$

China 3, 5, 8, 16-18, 20, 24, 29-30, $34,36,40,42,44,46,48,51-2$, 59n100-1, 63, 66, 69, 72, 74-5, 77-9, 82, 84, 93, 99, 101-2, 107, $122 \mathrm{n} 62,150$; ability to resist Japanese actions 73 ; belligerency 93 ; crisis in 32 ; defense 79 ; foreign policy toward Asia 24; invasion of 70; Japan aggression against 5; "lawlessness" 37; Manchu territory 31; natural resources 69; Open-Door policy 23; sea blockade of 76; sovereignty over Manchuria 31; warfare in 82,95

China Incident 61

Chinese activists 29

Chinese affair 103

Chinese Communist Party 61
Chinese terrorist act 30

Christianization 29

Chügai Shögyō Shinpō 23

Chungking (Chongqing) 61

Civil War 100

Cold War 181, 185

Communism 69

Communist Party 127

Communists 31,36

conference $73-5$

conflict and corporate world 69-71

Congress 93

consensus 32-5

Conservative Party 33

Conservatives 45,97

Continuation War 160

Coordination Committee of the League 100

corporate world 69-71

country-of-origin 19

country-of-purchase 19

Covenant of the League 32-3, 40-1, $62,72,75,78,96,98,100,119$ n19

Cox, M. J. 3, 113

C.P. Thunberg memorial 22

Craigie, R. 108, 135

crisis management 76-7

cultural barrier 30

Czechoslovakia 40, 42, 48, 54

da Silva, R. 137

Dairen (Dalian) 32, 56n18, 110, 149

Danzig 92

Davis, N. 73

de Brouckère, M. 210

debates 126-9

defeatism 106

defending national interests $37-8$

Defense Act of 192534

Delbos, Y. 73

Den Svenske Nationalsocialisten (The Swedish National Socialist) 65

Denmark 3, 6-7, 18, 24, 39, 74, 94, $100,112,128,137,181$

Den'nenchōfu camp 138

Der Stürmer 65

diplomacy: Asia 75-6; China 71-7; conference $73-5$; crisis management 76-7; Europe 105-14; Japan's late appreciation for Swedish intelligence 144-6; league response 71-3; Neutral Committee of the YMCA 140-4, 142; new jobs for Swedish diplomats 137-40; new diplomats for Swedish 
jobs 136-7; in the Pacific 129-46; protecting Japan 132-5; Sweden 75-7, 129-32, 130; Swedish-Swiss collaboration 140-4; trade under protest 37-46

Dongsansheng (The Three Eastern

Provinces) 29

Drummond, E. 42

Dutch East Indies 9, 132

Dutch Government 132

early Swedish-Japanese relations 14-25; decision makers 24-5; Great War 19-24; impact of 1905 16-19; institutions 24-5; interwar period 19-24; Swedish representatives to Japan $\mathbf{1 5}$

East Africa 100

East Asia 1, 17-18, 29-31, 34-7, 45, $47,51,53,56 n 36,61-5,70-1,77-8$, $82,84,107,128,132,144$; colonial goods 48; commercial decline 80; Japanese policy 75; Swedish relations with 84; Swedish-Japanese relations 95

economical yellow peril $27 \mathrm{n} 18,49$

Ecumenical Board of Sweden 66

Eden, A. 73

Eguchi, K. 8

Egypt 130

Ekman Foreign Agencies Ltd. 69

Enander, M. 67

Engberg, A. 39, 56n36

Engelbrecht, H. C. 93

England 162

Enskilda Bank/Enskilda Banken 117, $124 \mathrm{nl} 14$

Enstedt, F. 143

Ericson, N. E. 70, 136, 138, 141-3, $150,172,210-21$

Ethiopia 53, 75

Eurén, S. Y. 69

Europe 3-7, 16, 29, 31-2, 49, 64, 79, 92-3, 97, 102-3, 105, 112, 114, $116-17,125,127,129-30,146,181$

European war 92-5

Ewerlöf, O. 23, 37, 107

Extraordinary Assembly 38, 42

Far East 9, 18, 20, 32, 36-9, 42, 46-7, $65,74,102,209$

Farmers' League 33, 39, 97, 99

Fascism 69

“fifteen-year war" (jügonen sensō) 8
Finance Ministry 81

Finland 7, 40, 93, 100, 112, 128, 165, 169,181

First World War 5, 114, 116

Foreign Ministry 77

foreign policy 24; indictment of Swedish 2; Japan 10, 103, 161, 175; making of 38-41; solidaristic 63; Stockholm 24; Sweden 4-6, 9, 12n16, 16-17, 24, 33, 37-8, 53, 63, 70-1, 96, 118 ; United States 126

Foreign Policy Committee 127

foreign trade $17,25,29,46,53,68,78$, $94,144,184$

Formosa (Taiwan) 140

France 14, 16, 24, 35, 48, 73-4, 92, 94, $98,102-3,130$

Franco, F. 32, 73

Franco y el Imperio Japonés (Franco and the Japanese Empire) (Rodao) $1 \ln 5$

Free-Minded National Association 33

French Indochina 62

Fujiwara, A. 8

Fujiwara, G. 50, 95

Fujizawara 108

fukuzatsu kaiki 92

Gadelius 22, 32, 47, 69, 70, 81, 83, $148-9$

Gadelius, K. 18, 36

Gaimushō 30, 77, 103, 113, 126, 131-2, 135, 137-40, 144, 149, $151-3,156 n 50,156 n 60,182$

General Export Association 82-3

Geneva 33, 35-9, 42, 44, 46, 48, $54,63,72,74,84,95,98,104-5$, $122 \mathrm{n} 62,141,185$

George VI 169

German Krupp Company 83-4

German-Manchukuo Trade Agreement 52

German Reich 78-9, 83, 94, 128, 130

German Reichsmark 117

German-Soviet Non-Aggression Pact 104

Germany 3, 5-7, 16, 19, 32, 45, 76, $92,94,101-4,112,116-17,125$, 128-30

global turmoil 92-5

Good Earth, The (Buck) 64

Good Offices 129-30, 140-1, 154

Gorgé, C. 105, 109-10, 142, 182

Göteborgs Handels- och Sjöfartstidning (Gothenburg Trade and Shipping 
Gazette) 35-6, 58n81, 65, 68, 75, $87 \mathrm{n} 35,94,127$

Gothenburg 6, 18, 46, 48, 67-8, 78

Great Britain 3, 6, 14, 16, 24, 32, 35, $48,65,67,73-5,77,79,92,98$, $102-4,116,125-6,130,133-4,167$, 175,183

Great Depression of 192946

great Kantō earthquake (1923) 22

Great Powers 14, 34-8, 44, 53, 63, $71-3,75,92-3,97-9,106,210$

Greece 135

Greiffe, A. 152

Grew, J. C. 8, 126

Gripsholm 134

Grossraumwirtschaft 6

Günther, C. 93, 127, 162, 164, 169-70, 170n49

Gustaf V (King) 94-5, 169

Gustav, A. 22-3

Guston, G. 50-3, 60n121, 69-71, 83,110

Hagberg, H. 48

Hägglöf, G. 6, 117, 144, 147

Hangzhou 61

Hanighen, F. C. 93

Hansson, P. A. 5-7, 41, 56n36, 64, 93-5, 99

Hanstholm 94

harakiri 81

hardliners 41

Hata, S. 104

Hawaii 9, 10, 132-3, 153

Hearn, L. 17

Heder och samvete (With honor and conscience) (Boëthius) 2

Hedin, S. 17

Helsinki 45, 107, 145

Haile Selassie 98

Himmler, H. 129

Hioki, E. 23

Hiranuma, K. 92, 102, 104

Hirohito (Shōwa Emperor) 22-3

Hiroshima 4, 181

Hirota, K. 71, 87

Hitler, A. 7, 35, 64, 92-3, 100, 102, $104-5,107,114,117,169,181$

Hoare-Laval Plan 98

Holme, Ringer \& Co. 110

Honduras 135

Hong Kong 48, 131, 143, 149

Honolulu 133

Hota, E. 8
Hsinking (Xinjing/Changchun) 71, 82

Hu Shize 71, 75

Hull, C. 92, 125, 145, 162

Hultman, J. E. E. 32, 37, 70, 107

Hungary 18

Hvar 8 Dag (Every Eight Days) 17

Hymans, M. 210

Iceland 3, 128

idealism and realism $32-5$

Imai, S. 8

Imperial Navy 125

India 48,132

Indochina 9, 104, 126

Indonesia 9

industrial modernization 20

Informationsbyrain Mellanfolkligt Samarbete för Fred (Information

Bureau on the International

Co-operation for Peace) 67

Institute of Pacific Relations 164, $164 n 26$

International Committee of the Red Cross (ICRC) 141-2, 153

International Concession of Shanghai 61 international law 5, 31, 34, 47, 94, 103

International Military Tribunal for the Far East (IMTFE) 161, 165-6, 170

International Peace Campaign 66

international politics 29-32; bilateral relations 95-6; bridge to war 61-2; Europe 92-6; in the Pacific 125-6

internationalism 1, 41, 54, 105

Iran 3

Ireland 42

Irish Free State 9

Italy $5,16,24,32,44,71,75,98$, 100,103

Iwakura, T. 16

J.A. Kjellberg \& Sons 27n21, 47, 83

James, E. 113, 136

James, W. 110, 111

Janson, H. 143

Japan $1-2,5,8-9,1 \ln 4,24,29,31-2$, $35,41-2,44,46-50,62-3,65,67$, $74,79,82-4,92-5,101,103-4$, $106,112,114,133,137,161$, 183; actions as illegal 74; actions in China 95, 114; aggression 5, 127; aggressive challenge in East Asia 184; belligerency 31, 71, 76, 185; economic development 148; economy 69; euphemism 93; foreign 
policy 161; industrial modernization 20; invasion of Manchuria 49; late appreciation for Swedish intelligence 144-6; military actions 38; military alliance 102 ; military expenditures 44 ; military occupation 42 ; military repression 4; modernization 14 ; nationalization 80, 150, 153; opendoor policy 69; parliamentarism 31; political leadership 159; polity (kokutai) 153; power structures 37; Privy Council 84; protection 132-5; "sakoku" 25nl; Sweden collaboration with 3; war against the Allies 146; war in China 68; warfare in China 96

Japan Railway 115

Japan Times 135, 135

Japan-China Trading Company 140

Japanese Cabinets 206-8

Japanese diplomats in Sweden

\section{2,145}

Japanese Empire 29, 51-2, 101, 110,139

Japanese Government 10, 31, 70, 76, $81,85,92,148,151,164,174-5$

Japanese Military Police 3, 135

Japanese Ministry of Foreign Affairs (Gaimushō) 10

Japanese Navy 76, 133, 150

Japanese Sea 1

Japanese "strange" neutrality 100-5

Japanese trade with Sweden 22

Japanese-American relations 125

Japanese-British alliance 92

Japanese-Soviet relations 102

Japan's Feet of Clay (Utley) 49

Jarring, G. 177n77

Jews 18

Johansen, E. F. 137

Johnson, H. 164, 172

Kallin, N. 136, 139-40

Kantō Army 30-1, 54, 64

Kantō Leased Territory 71, 110

Kantō Peninsula (Liaodong) 30, 139

Karlgren, B. 95

Karuizawa 152

Kase, T. 174-6

Kaunas 7

Kecskemeti, P. 174

keeping commerce alive 114-17

keeping relations alive 112-14

Kellogg-Briand Pact 84, 96

Kengelbacher, F. 143
Kenpeitai 113, 135

Kjellberg 83

Kjellén R. 17

Kobayashi, T. 163

Kobe 113

Kong Xiangxi (H. H. Kung) 12ln62

Königsberg (Kaliningrad) 115

Konoe, F. 75-6, 104-8, 163-4

Koori, T. 58n66

Korea 9, 16, 29, 181

Krebs, G. $11 n 15$

Kristiansand 94

Kuriles 29

Kuriyama, S. 79

Kurusu, S. 75

Kwantung Army 38, 101

Labour Party 67

Latin American Chaco War 44

Latvia 145

Law of Neutrality 2, 5, 7

League Council 38-9, 106

League Covenant 36, 66

League of Nations 1, 5, 10, 24, 30-1, $33-4,36,38-9,42,44-5,48,53-4$, 56n36, 62, 64, 67, 71, 73-5, 78, $84,95-7,99,107,118,141,183-5$, 209-10

Lend-Lease Act 125

Lensen, G. A. $12 \ln 57$

Liaison Conference 102

Liberal Party 97

Liechtenstein 97

Lindhagen, C. 66, 69, 96

Lindman, A. 39-40

Litvinov, M. 73, 106, 145

Löfgren, E. 40-1, 54, 209-10

London 8, 44, 71, 92, 103, 107, 141, 146,163

Long Second World War 7-9, 181, 183,185

Lord Halifax 162

Lord Lytton 31

Lourenço-Marques (Maputo) 133, 144

Lugouqiao 61

Luxemburg 97

Lytton Commission 41

Lytton Report 41-2, 44

MacArthur, D. 182

Madame Butterfly (Puccini) 17

Madariaga, S. 42

Madrid 32, 165

Mallet, V. 162-3 
Manchukuo 30, 42, 44, 51-4, 52, 70-1, $75,81,101,116,141,162,169$

Manchuli (Manzhouli) 1

Manchu-Mongolian 101

Manchuria 4, 29, 32-3, 38, 45, 49, $54 \mathrm{n} 4,69,72,181$

Manchurian 37, 48, 88n49

Manchurian Incident 29, 32

Manila 143, 152

Manila Massacre 8, 183

Mao Zedong 62

Marco Polo Bridge Incident 8, 61, 71 84,185

Matsuoka, Y. 42-3, 43, 104-5, 112, 125-6

Matsushima, K. 71

Matsushima, S. 95, 112

Meiji Government 14

Mendez de Vigo, Santiago Mendez de Vigo y 109

Merchants of Death (Engelbrecht and Hanighen) 93

Mexico 135

Middle Kingdom 69

milieu goals 38

militant extremism 30

military action and its aftermath 29-32

military invasion 30

Ministry for Foreign Affairs 12nl6

Ministry of Greater East Asia 144

Ministry of Trade (MOT) 25

Miramar 149-50

"Missions Archive" (Beskickningsarkiv) $12 \mathrm{nl} 6$

Mitsubishi Corporation 116-17, 148

Mitsui 117, 148

modernization 14, 20, 82

Molotov-Ribbentrop Non-Aggression Pact 92

Monaco 9

Moreno, R. 10

Moscow 1, 33, 103, 115, 125, 127, $136,146,175,181$

most-favored-nation 14

Mozambique 133

Mukden Incident 8, 33, 69, 95, 209

Mukden (Shenyang) 29, 37, 44

multilateralism to bilateralism 105-7

Mushakōji, K. 29-30, 43, 45, 161

Mussolini, B. 32, 53, 64, 98, 100

Nagasaki 4, 22, 181

Nanking Massacre (Nanjing Massacre) 61,68
Nanking (Nanjing) 61-2

National Board of Trade 25, 83

national politics $32-6$; boycott movement 66-9; China 61-71; conflict 69-71; corporate world 69-71; debates 126-9; Europe 96-105; freezing trade with Japan 66-9; in the Pacific 126-9; shifting opinions 64-6; Swedish foreign policy 62-4; war in East Asia 62-4

National Socialists 65

nationalism 69,81

Nationalist Party 48, 62

Nazi Germany 2-3, 64, 173

Nazis 18

Negishi internment camp 139

Netherlands 3, 9-10, 24, 37, 42, 100,135

Neutral Committee of the YMCA $140-4,142,153$

neutral wartime diplomacy 3

neutrality 4-7, 120n33, 124n1 19

Neutrality Pact 104-5, 125

Neville, G. A. 111

new minister 107-10

Nihon Yūsen K.K. (NYK) 48

Nine-Power Treaty of 1922 23-4, 62, 73,84

Ningpo (M/S) 78, 149-50

Nippon $(M / S) 78$

Nippon Yūsen Kaisha (NYK) 48, 78

Nishimura, T. 145

Nitobe, I. 22

Nomonhan (Khalkhin-Gol) 92, 102

Nomura, K. 125-9

Non-Aggression Pact 102, 105, 118

non-belligerent 94; see also belligerents

Non-Intervention Committee 73

Normandy 6

Norrskensflamman 127

North America 5

North Asia 101

Northeast Asia 48, 101

Northern China 63

Northern Europe 6, 94

Norway 3, 6-7, 17, 24, 39, 74, 93-4, $100,112,128,131,135,181$

Nya Dagligt Allehanda 44, 58n81, 65, 68

Nye Committee 93

Ohlin, B. 49

Ōji Seishi (Ōji Paper) 50

Okada, K. 31 
Okamoto, S. 144-6, 151, 166, 169-70,172-5, 172n56

Olofson, A. 136

Olson, G. W. 133

Onodera, M. 45, 112, 145-6, 151, 172-3, 176

Onodera, Y. 32, 145

Operation Barbarossa 117

Opium War 14, 75

Osaka 49, 113

Ōshima, H. (Ambassador) 102

Ostasiatiska Kompaniet 78-9

Pacific Ocean 1, 116, 167

Pacific War 8, 10, 96, 175, 183, 185

"Pact of Steel" 102

Palairet, M. 62

Paravicini, F. 142

Paris 7, 71, 92, 103, 107

parliament 32-6

Parliamentary Committee on Foreign

Affairs see Utrikesutskottet

Parliamentary Treaty Committee 70

Pearl Harbor 4, 7-8, 92, 118, 126, 129, 133, 137, 139, 146, 153, 183, 185

Peking (Beiping/Beijing) 24, 46, 61

Perry, M. C. 14

Philippines 9, 152

Poland 7, 92-3, 100, 102, 117, 130

"political neutrality" 106

Politis, N. 124nl19

Popular Front 62

Portugal 24, 140, 151

possession goals 38

post-crisis 49-51

post-World War II 125

Prince Carl Senior 172

prisoners of war (POWs) 10, 129, $138-43,152-3$

private foreign policy 68 ; see also foreign policy

pro-Allied 94

pro-Axis 94

Protecting Power 129-33, 130, 137, $139,151,153,155 \mathrm{n} 26,156 \mathrm{n} 50$, $163-4,185$

Prytz, B. 83, 87n36

Pu Yi 31

public, national politics $32-5$

public opinion 64

Puccini, G. 17

quasi-nationalization of Swedish commerce 146-50 racial equality 23

Ramel, F. 29, 37-41

realism see idealism and realism

Red Army 101-2

Reginbogin, H. 124n118

Reischauer, E. O. 8

Republic of China 31, 55n4, 74-5, 77, 107, 181

Rhineland 32, 98

Riga 7, 145

Riksbanken 117

Riksdag 18, 36, 39, 98, 100, 128

Ringer, F. 3, 110, 113

Ripa, O. 111, 182

Rodao, F. $1 \ln 5$

Rome 8, 102-4, 107

Roosevelt, F. D. 92, 125

Russia 14, 16, 23, 145, 175

Russo-Japanese War of 1905 15, 30, 41,127

Saigon 149-50

Saitō, S. 141-2

Sakaya, T. 165-6, 168, 170, 176

sakoku $25 \mathrm{nl}$

San Francisco 182

San Marino 9

Sandler, R. 5, 40-3, 45, 53, 62-3, $66,73-5,77,79,93,98-100,106$, $120 \mathrm{n} 30$

Sandviken 81

Scandinavia 2-4, 46, 65, 76, 112, 128

Second Hague Convention of 190710

Second Sino-Japanese War 61

Second World War (1939 to 1945) 7-9

Section B 130, 136-7, 141-2, 149, 154

Section U 128

Segerstedt, T. 35, 65, 68

Shanghai $30,34,37-40,46,48,61$, $74-6,78,82,107,143,149$

Shanghai Chamber of Commerce 41

Shigemitsu, M. 109, 153, 161, 165-70, $175-6,181-2$

Shiratori, T. 45

Siberia $115,117,147$

Simon, J. 41

Singapore 138

Sino-Japanese conflict 36, 88n49

Sino-Japanese War 64, 93

Skagerrak Barrage 80, 94

"small state-side" (shōkokugawa) 4l-4

Social Democratic Party 34, 67

Social Democratic Workers Party 33 
Social-Demokraten (The Social

Democrat) $34,41,56 n 36,62,67$, $72,95,98-100,127$

Socialist Party 36, 98-9

Söderblom, K G. 76

South Africa 130

South Manchurian Railway 29-30, 32-3

South Sea Bureau 144

Southeast Asia 48, 101, 104-5, 126,132

Soviet Government 115

Soviet Neutrality Pact 164

Soviet Russia 79, 94

Soviet Union 1, 3, 7-8, 46, 49, 54, $82,92-4,101-5,107,117,128-9$, 156n64, 160, 169

Soviet-Finnish Winter War 145

Sovietization 69

Spain 1, 1ln4, 24, 40, 42, 100, 110, 132-3, 140-1, 151

Spanish Civil War 32, 68, 73

Special Conference on Chinese Customs Tariff 23

S.S. Miramar 150

Stalin, J. 102, 164

Stettinius, E. 171

Stockholm 1-8, 15, 23-4, 29, 33, 35-6, $38,41-3,45-6,50-1,54,71-4$, $77-8,83,93-5,98-9,105,107,112$, 114-15, 126-8, 130-2, 134, 144-6, $154,163,165-74,185$

Storry, R. 176

“strange neutrality" $12 \ln 57$

Sugiyama, H. 61

Suzuki, B. 161, 163

Svensk Tidskrift (The Swedish Journal) 69

Svenska Dagbladet (Swedish Daily) 35,127

Svenska Kullagerfabriken (SKF) 32-3, $47,50,69,80,83,117,147-9$

Svenska Morgonbladet (Swedish Morning Post) $34,36,39,87 \mathrm{n} 35$

Svenska Tändsticks AB (STAB) 150-1

Sweden 1, 8, 24, 38, 41-2, 45, 48-53, $67,75-8,80,92-5,100,103,106$, $110,112,117,141,147,159$; achievements 160; collaboration with Japan 3 ; colonial-era policies 75; "colonial goods" 48; defense 93; diplomatic protests 77; economy 20; experience of World War II 2; exports to Japan 21 ; food security 51 ; foreign policy 4-6, 9, 12nl6, 16-17, $24,33,37-8,45,53,63,70-1,84$, 96-7, 118, 128; foreign trade 46, 94, 184; Good Offices 141; immigration policy 128; imports and exports 4 , 19, 19-20, 47, 80, 115, 147, 147; interactions with Asia 7; international policy 97; loyalty to the League 63; military defense 99; national security 7 ; neutrality policy 100; as protecting power 129-32, 130; representation of Japanese interests 131-2; secession from the League 44; security strategy 106; statistical bureau 82 ; trade 21 , 78,123 n 102; "traditional neutrality" 96; wartime bilateral relations with Japan 9; wartime foreign policy 6 Swedish Bureau of Foreign Trade 147

Swedish Cabinets 205

Swedish Christian mission 55nl

Swedish Communist Party 98

Swedish Defense Committee 44

Swedish East Asia Company 18, 32

Swedish Federation of Trade Unions (LO) 67

Swedish Foreign Ministry 159, 162, 167, 169, 176

Swedish General Association of Exporters 25

Swedish Government 63, 105, 144, $161,169,171,174$

Swedish legation 110, 110-11, 135

Swedish Liberal Party 23

Swedish Match Corporation (STAB) 69

Swedish National Archives 162, 164,167

Swedish Navy 15

Swedish Olympic Committee 68

Swedish representation of foreign interests in World War II 222-5

Swedish State Railways 6, 94

Swedish "strict" neutrality 96-100

Swedish Trade Bureau 149

Swedish-Japanese Association 29, $45,119 \mathrm{nl} 3$

Swedish-Japanese bilateral trade 114

Swedish-Japanese relations 49, 95-6, 104-5, 114, 150, 153, 185

Swedish-Japanese trade relations 146

Swedish-Japanese trade value 80

Swedish-Swiss collaboration 140-4

Swiss Government 141

Switzerland 1, 7-8, 14, 40-2, 97, 100, 109-10, 133, 141, 151, 153, 165 


\section{Index}

Taisei Yokusankai (the Imperial Rule Preservation Association) 104

Taishō Democracy 23

Taiwan 9, 16

Takahashi, K. 31

Takamatsu (Prince) 23

Tallinn 7, 115

Tani, M. 82

Taube, C. 32

Tennberg, I. 70

Tenno's Empire 16, 44, 64

Thailand 143

"theory faction" (rironha) 41

Third Reich 35

Thörnell, O. 94

Thune, R. 69

Tianjin 46

Tientsin (Tianjin) 61

Tōgō, S. 150, 168-75

Tōjō, H. 126, 144, 150

Tokyo 1-3, 7-8, $1 \ln 12,12 \mathrm{nl} 6,16$, $18,30,35,37-8,41,44,49-51,62$, $71-3,75-8,81-2,92,101-4,107$, $111,113-14,125,127,132,134$, $136,138,140,144,146,151,153$, $160,181-2$

Tokyo Olympic Games of 194068 total war in China 61-85; diplomacy 71-7; international politics 61-2; national politics $61-71$; trade $77-84$

total war in Europe 92-118; diplomacy 105-14; international politics 92-6; national politics 96-105; trade 114-17 total war in the Pacific 125-54; diplomacy 129-46; international politics 125-6; national politics 126-9; trade 146-53

Toyada, T. 126

trade 46-54, 77-84; China trade with Japan 79-82; China trade with Manchukuo 82-4; commercial difficulties 77-9; Europe 114-17; in the Pacific 146-53; quasinationalization of Swedish commerce 146-50; Sweden 123n102; worsening relations on all fronts 150-3

Trade Bureau of the Gaimushō 81 trade deficit 81

trade policy $25,53,184$

trade realism $51-4$

trade under protest 29-54; diplomacy 37-46; international politics 29-32; national politics $32-6$; trade $46-54$
Trans-Siberian Railway 169

Treaty of Commerce and Navigation (1911) 92

Treaty of Kanagawa 25n2

Treaty of Versailles 75

Tripartite Pact 103-5

Troedsson, I. 136, 138, 140

Tsingtao (Qingdao) 61

Tsurumi, S. 8

Turkey $8,45,151$

Undén, Ö 5, 33-4, 38-9, 41-3, 63, $72-4,98-9,105,12 \ln 58$, $177 \mathrm{n} 77,181$

Under brinnande krig 87n35

unequal treaties 64

United States 1, 3, 5, 7, 14, 16, 20, $23-4,35,46,48,63,67,73-4,77$, $79,92-3,104,117,125-7,133,141$, $152,162,168,172,175,183,185$; arms trade 93; counterintelligence 146; intelligence 145; neutrality laws 61, 101; treaty between Japan $25 \mathrm{n} 2$; "true neutrality" 103 ; weapons exports to China 93

Uppsala University 34,100

US-Japanese relations 133

US-Japanese wartime 133

USS Missouri 181-2

USS Panay 76

USSR $3,5,92,101-4,112,117,125$, $127,140,146$

Utley, F. 49, 67

Utrikesdepartementet (UD) 2, 4-5, 24-5, 26n9, 37-8, 45, 62, 72-4, 77, $79,84,93,106,110,112,113,115$, $133-4,136-7,140,146,149,151$, $154,155 \mathrm{n} 26,185$

Utrikesnämnden (UN) 24, 63, $12 \ln 58$

Utrikesutskottet 127-8

Utrikesutskottet (UU) 25

van Polsbroek, Dirk de Graeff 14

Vatican 140, 165

Versailles 98

Vietnam 150

Vladivostok 115

von Dardel, G. 73-5

von Post, E. 164, 168

von Ribbentrop, J. 168

von Sydow, E. 108, 111, 122n69, 138, $159,176 \mathrm{n} 70$ 
Wachtmeister, C. F. 73

Wägner, E. 67

Wakatsuki, R. 30

Wallenberg, A. O. 124n114

Wallenberg, G. O. 18-20, 23

Wallenberg, K. 18

Wallenberg, R. 18, 129

Walters, F. P. 74

Wang Jingqi 66

Wang Jingwei 62, 75

Wang Xiaolai 41

War in the Pacific 45

War Trade Agreements 6

wartime diplomacy 9-11

Washington 8-9, 76, 92, 125-6, 133, 153,163

Weimar Republic 93

Wendbladh, U. 136

Wenner-Gren, A. 71

Wester, G. 136

Western Great Powers 56n36, 76

Westernization 45

Westman, K. G. 33, 39-40, 95, 99-100, 106

Westman, K. I. 39, 71-2, 74, 122n62

White Papers 25, 37

Wilhelm II (German emperor) 17
Winter War 93-4, 100, 112

Wirén, L. 136, 138

Wistrand, H. 111

Wolfers, A. 38

World War I 18, 20, 41, 77, 92, 96-7, 130,184

World War II 1-3, 108, 122n68, $124 \mathrm{n} 118,128,155 \mathrm{n} 26,159-60$

xenophobia 4

Yangtze (Yangzi) river 76, 78

Yasukuni-maru 78

Yen-bloc 81

Yokohama 18, 22, 48, 51, 69, 110, $116,136,139,140,147-8$

Yokohama Amateur Rowing Club $156 n 60$

Yokohama Specie Bank (YSB) 117, 149

Yomiuri Shimbun 42, 43

Yonai, M. 104

Yoshino, S. 87

Young Men's Christian Association (YMCA) 14l-2, 144

Zhu Changnian 38 


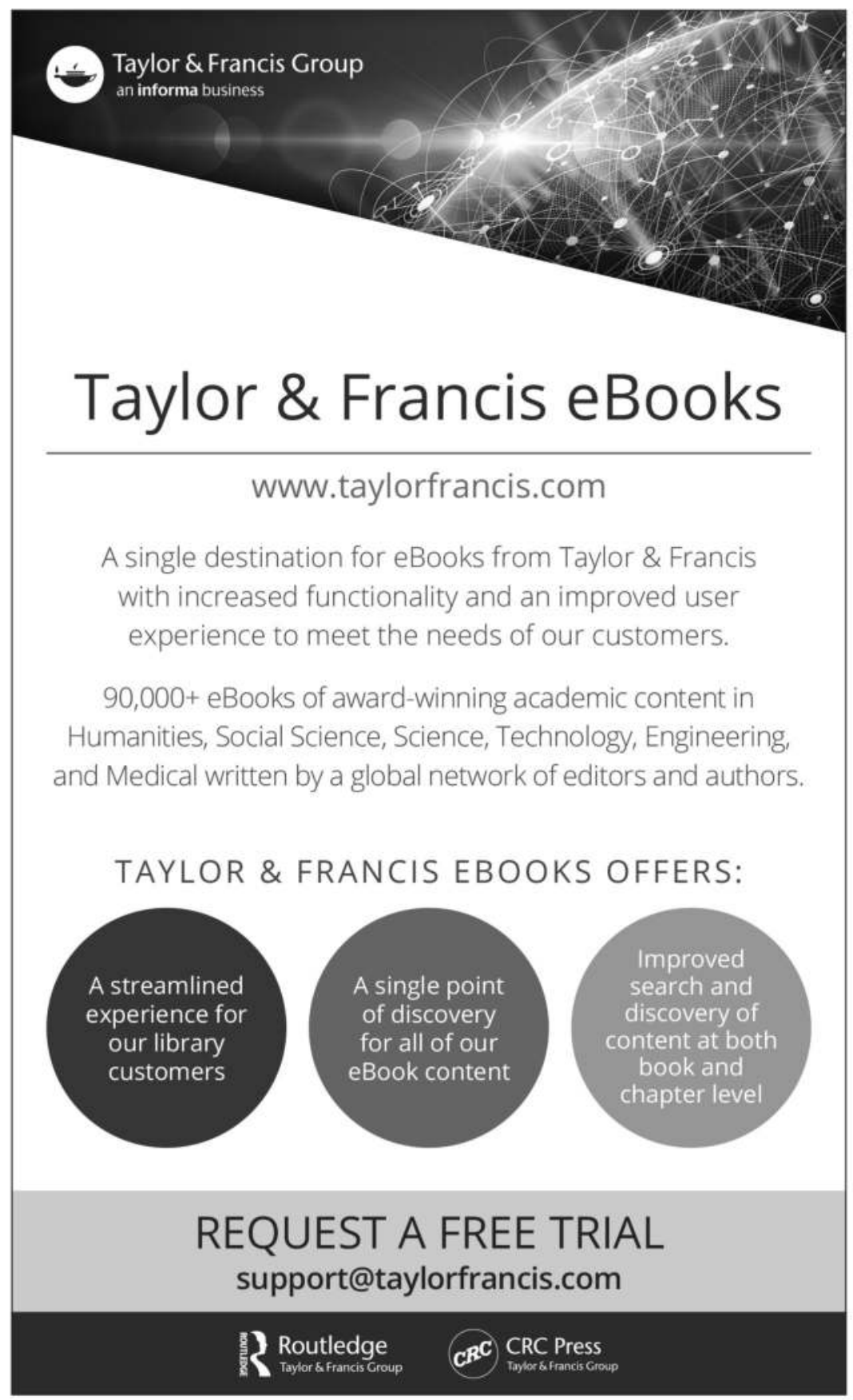

